\title{
AUDITING AND EARNINGS MANAGEMENT \\ IN NEW ZEALAND
}

by

LE HOAI NAM

\begin{abstract}
A thesis
submitted to the Victoria University of Wellington in fulfilment of the requirements for the degree of Doctor of Philosophy
\end{abstract}

Victoria University of Wellington 2014 


\section{ACKNOWLEDGEMENTS}

The journey I have undertaken to complete this $\mathrm{PhD}$ has been made possible with the support of my supervisors, funding bodies, colleagues, friends, and my family. I would like to express my sincerest thanks to my supervisors, Professor Mark Tippett (Sydney University, Australia) and Dr Thu Phuong Truong, for their devoted academic guidance and support throughout the process of my $\mathrm{PhD}$ study. I am also indebted to Professor Tony van Zijl and Dr Carolyn Cordery for their assistance during the period of my study at Victoria University of Wellington. My gratitude also goes to the staff of the School of Accounting and Commercial Law and $\mathrm{PhD}$ colleagues in Victoria University, who have given me invaluable encouragement and advice regarding my thesis. In particular, discussions with Dimu Ehalaiye which sometimes lasted right through the night, were both a joyful experience and helped to resolve many issues and problems that arose during the writing up of this thesis.

I also wish to express my gratitude to the Vietnamese Government and Victoria University of Wellington for providing me with the $\mathrm{PhD}$ scholarship for four years. Special thanks go to Auditor General of State Audit of Vietnam (SAV) and especially Mr Dao Van Dung, the head of General Affairs Department of SAV, who has supported my professional development in many ways.

My special acknowledgement is to my family; in particular, my Mum, Dad, brother, sister and my beloved children, Le Hoang Minh and Le Ngoc Mai. I also express special thanks to my love, Doan Thanh Nga, who provided an impetus like no other to complete the thesis. 
And foremost, thank you, Mark Tippett, not only have you gone far beyond your duties as a supervisor, but have also been a most dedicated, patient and inspirational mentor for my life. 


\section{STATEMENT OF ORIGINAL AUTHORSHIP}

I hereby declare that this submission is my own work and to the best of my knowledge it contains no materials previously published or written by another person, or substantial proportions of materials which have been accepted for the award of any other degree or diploma at Victoria University of Wellington or any other educational institutions, except where due acknowledgement is made in this thesis. Any contribution made to the research by others, with whom I have worked at Victoria University of Wellington or elsewhere, is explicitly acknowledged in this thesis.

I also declare that the intellectual content of this thesis is the product of my own work, except to the extent that assistance from others in the project's design and conception or in style, presentation and linguistic expression is acknowledged.

Signature:

Le Hoai Nam 


\section{TABLE OF CONTENTS}

ACKNOWLEDGEMENTS

.. $\mathbf{i}$

STATEMENT OF ORIGINAL AUTHORSHIP....................................................................iii

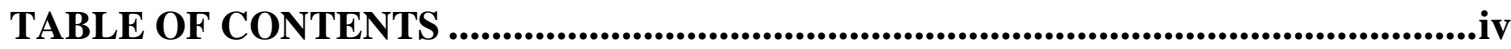

LIST OF TABLES AND FIGURES ........................................................................vii

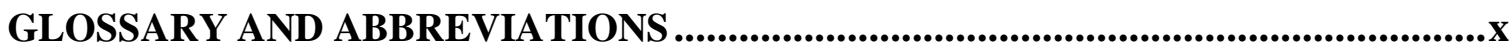

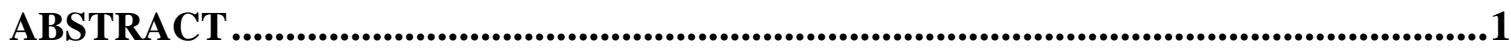

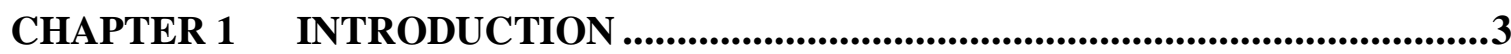

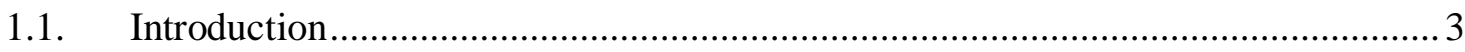

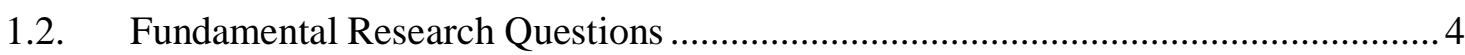

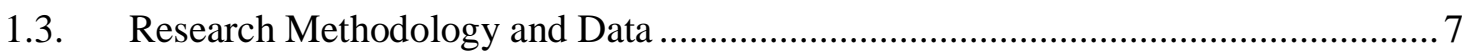

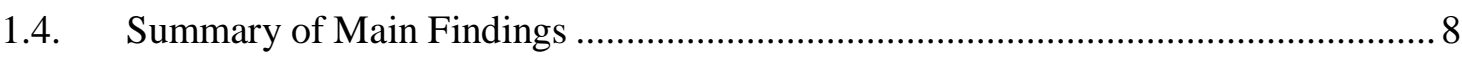

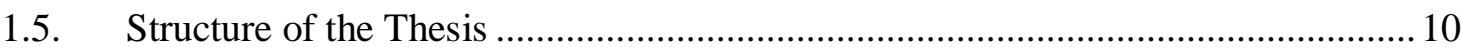

CHAPTER 2 LITERATURE REVIEW ..........................................................14

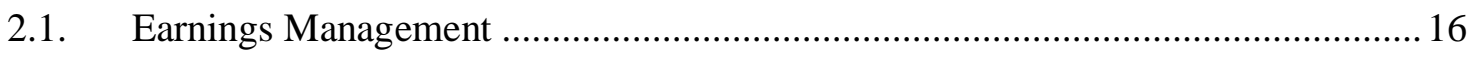

2.1.1. Definitions of Earnings Management .............................................................. 16

2.1.2. Incentives for Earnings Management ........................................................ 18

2.1.3. The Methods of Earnings Management ............................................................. 26

2.1.4. Measuring Earnings Management ….......................................................... 30

2.2. Audit Factors and Earnings Management .......................................................... 47

2.2.1. Big N Auditor and Earnings Management ..................................................4

2.2.2. Audit firm's Office Location and Earnings Management .............................. 48

2.2.3. Audit Busy Season and Earnings Management ...........................................49

2.2.4. Auditor Change and Earnings Management ................................................... 50

2.2.5. Audit Opinion and Earnings Management .................................................. 52 
2.2.6. Non-audit Fees and Earnings Management .............................................. 53

2.3. The Influence of Earnings Management on the Level of Audit Fees ......................56

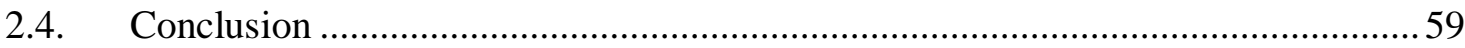

CHAPTER 3 RESEARCH SETTING IN NEW ZEALAND .................................61

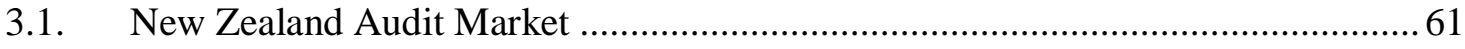

3.1.1. Overview of New Zealand Economy ........................................................... 61

3.1.2. New Zealand Audit Market Characteristics ..................................................6 63

3.2. Auditing Legislation Environment in New Zealand ............................................65

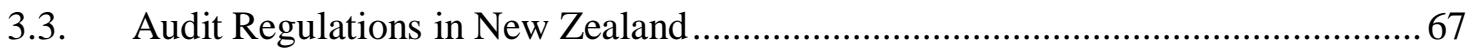

3.3.1. Provision of Non-Audit Services in New Zealand ........................................ 81

3.3.2. The Appointment and Replacement of Auditors in New Zealand................... 91

3.3.3. Audit Fee Negotiation in New Zealand ...................................................... 92

3.3.4. Audit Opinions in New Zealand................................................................. 93

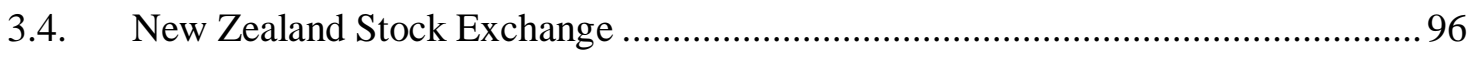

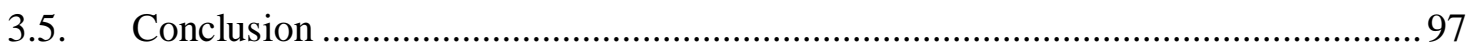

CHAPTER 4 HYPOTHESES DEVELOPMENT ....................................................99

4.1. The Impact of Audit Factors on the Level of Discretionary Accruals .................. 100

4.1.1. The Relationship between Big 4, Audit firm's Office Location and

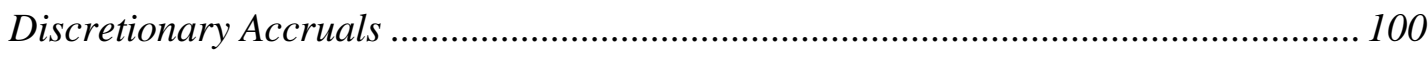

4.1.2. The Relationship between Audit Busy Season and Discretionary Accruals...... 103

4.1.3. The Relationship between Non-audit Fees and Discretionary Accruals...... 104

4.1.4. The Relationship between Auditor Change and Discretionary Accruals..... 105

4.1.5. The Relationship between Audit Opinion and Discretionary Accruals........ 107

4.2. The Relationship between Discretionary Accruals and Audit Fees ...................... 108

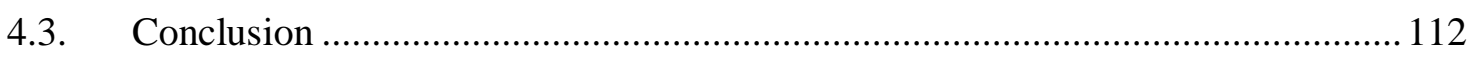




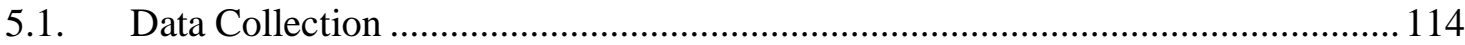

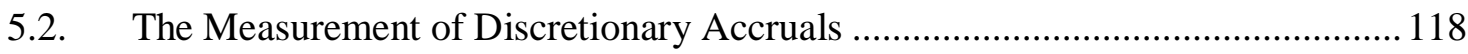

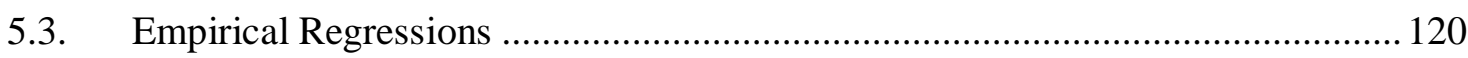

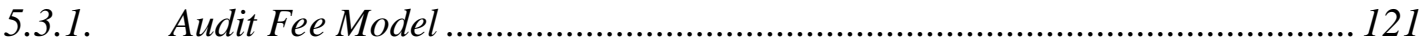

5.3.2. Discretionary Accruals Model................................................................ 125

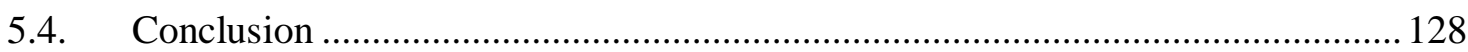

CHAPTER 6 EMPIRICAL RESULTS ..............................................................129

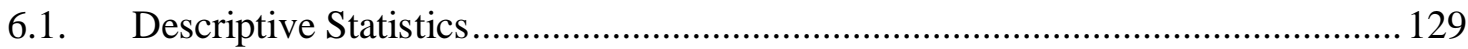

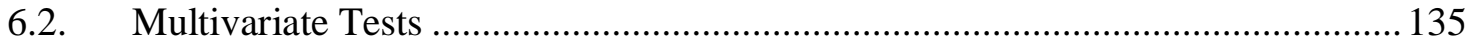

6.2.1. The Impact of Audit Factors on Discretionary Accruals............................. 135

6.2.2. The Impact of Current Discretionary Accruals on Next Year's Audit Fee.... 139

6.3. Robustness and Sensitivity Tests ................................................................ 142

6.3.1. Tests for Discretionary Accruals Models .................................................. 142

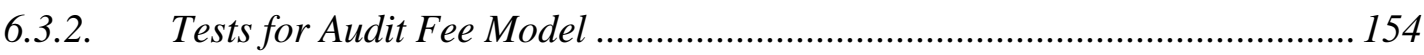

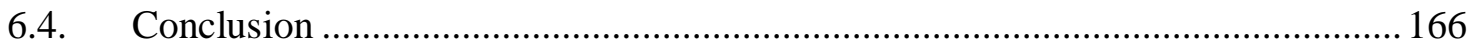

CHAPTER 7 SUMMARY AND CONCLUDING DISCUSSION ...........................167

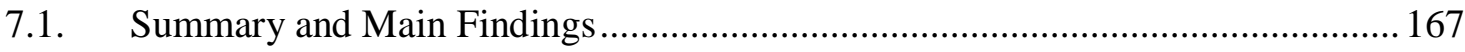

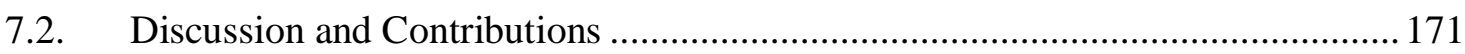

7.2.1. Auditor Quality and Discretionary Accruals............................................ 171

7.2.2. Audit Busy Season and Discretionary Accruals ........................................ 172

7.2.3. Audit Opinion and Discretionary Accruals ............................................... 174

7.2.4. Auditor Independence and Discretionary Accruals ................................. 175

7.2.5. Response of Audit fee to Discretionary Accruals ....................................... 176

7.3. Limitation and Suggestion for Future Research ............................................ 177

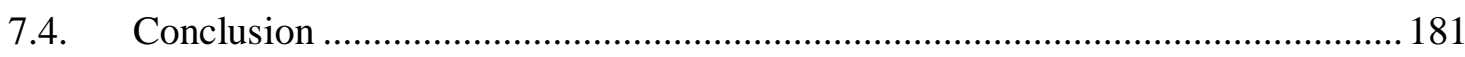

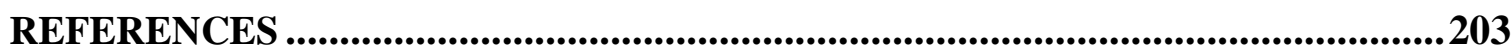




\section{LIST OF TABLES AND FIGURES}

Table 2.1: Classification of Earnings Management of Ronen and Yaari (2007)

Table 2.2. Motivations for Earnings Management Discussed in 39 AAERs.

Figure 2.1: Other Real Activities and Discretionary Accrual Manipulations 28

Table 2.3: Summary of the Relationship between Accruals and Cash flow in

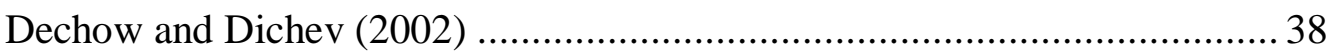

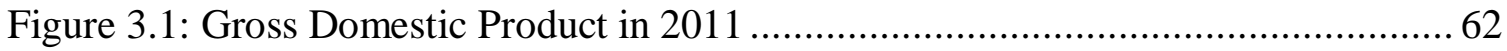

Figure 3.2: GDP per capita in 2011 63

Table 3.1: Audit Profession Oversight Functions changes under the New Zealand Auditor Regulation Act, 2011

Table 3.2: Summary of Code of Ethics issued by NZICA in 2002 as amended in 2003 and 2006

Table 3.3: Threats for Auditor Independence 74

Table 3.4: Lists of Threats for Auditor Independence Acknowledged by the NZICA 80

Figure 3.3: The Procedures for Audit Firms to Accept a Non-audit Service Engagement 82

Table 3.5: Safeguards for Reducing Threats of Non-audit Services 83

Table 3.6: Types of Modified Opinions 96

Figure 4.1: The Relationship between Earnings Management and Audit Fees 111

Table 5.1: Number of Firm-years Collected in Sample 116

Table 6.1: Average Audit fees, Average Non-audit fees and Average Total Assets across the $\mathrm{N}=567$ Firm-years Covering the Period from 2006 until 2010... 130 
Table 6.2: Descriptive Statistics of Audit Factors and Control Variables Employed across the $\mathrm{N}=567$ firm-years covering the Period from 2006 until 2010 .... 132

Table 6.3: Correlation Coefficients between all Variables across the $\mathrm{N}=567$ firmyears covering the Period from 2006 until 2010

Table 6.4: The Relationship between Audit Factors and Discretionary Accruals 138

Table 6.5: The Relationship between Discretionary Accruals and Audit Fees Paid in the Next Ensuing Year

Table 6.6: Standard OLS Regression versus OLS Regression with White (1980)

Adjustment

Table 6.7: Multicolinearity Tests for Discretionary Accruals model (Using VIF Factor)

Table 6.8: Multicolinearity Tests for Discretionary Accruals Model (Using Condition Index).

Table 6.9: Discretionary Accruals Model with Cluster Option by Firms and Years

Table 6.10: Regression Results with "eivreg regression" Option for Discretionary Accruals Model

Table 6.11: Alternative Methods for Estimating Discretionary Accruals 152

Table 6.12: A Comparison between Standard OLS Regression Results and OLS with the White (1980) Adjustment Procedure for Audit Fee Tests..... 155

Table 6.13: Variance Inflation Factors for Audit Fee Model. 156

Table 6.14: Condition Number Test for Audit Fee Model

Table 6.15: The Impact of the Level of Discretionary Accruals in Current Year versus Previous Year on the Level of the Audit Fee

Table 6.16: Testing the Relationship between the Level of Discretionary Accruals and the Level of the Audit Fee in the Next year with the Cluster Option by Firms and Years 
Table 6.17: Regression Results with "eivreg regression” Option for Audit Fees Model......

Table 6.18: Testing the Relationship between the Level of Discretionary Accruals (DACCs) and the Level of the Audit Fee in the Next Year using Different Measures of Discretionary Accruals 


\section{GLOSSARY AND ABBREVIATIONS}

$\begin{array}{ll}\text { AAERs } & \text { Accounting and Auditing Enforcement Releases } \\ \text { DACCs } & \text { Discretionary Accruals } \\ \text { IFAC } & \text { International Federation of Accountants } \\ \text { IPO } & \text { Initial public offerings } \\ \text { NZAX } & \text { The New Zealand Alternative Market } \\ \text { NZDX } & \text { The New Zealand Debt Market } \\ \text { NZICA } & \text { New Zealand Institute of Chartered Accountants } \\ \text { NZSX } & \text { The New Zealand Stock Market } \\ \text { NZX } & \text { NZX Limited } \\ \text { SEC } & \text { The Security Exchange Commission } \\ \text { SEO } & \text { Seasoned equity offerings } \\ \text { SOX } & \text { The Sarbanes-Oxley Act of } 2002 \\ \text { U.K. } & \text { The United Kingdom } \\ \text { U.S. } & \text { The United States }\end{array}$




\begin{abstract}
The research summarised in this thesis focuses on two research issues of particular importance to the New Zealand economy. First, the thesis examines the impact of audit factors on the level of earnings management. Second, the thesis empirically assesses the relationship between the level of earnings management and the audit fees charged by audit firms.
\end{abstract}

In the empirical work summarised in this thesis I use the absolute value of discretionary accruals (DACCs) as a proxy for earnings management. I estimate DACCs for each sample firm by using the modified Jones (1991) model. Moreover, several auditor characteristics have been employed in the thesis as proxies for auditor quality and independence. I use a BIG4 dummy variable (that equals 1 if the auditor is a Big 4 audit firm and 0 otherwise), an AOFFICE dummy variable (that equals 1 if the audit firm's office is located in Wellington or Auckland and 0 otherwise), an AO dummy variable (that equals 1 if the client firm receives a qualified or conditional audit opinion and 0 otherwise) and a FISCAL dummy variable (that equals 1 if the client firm's fiscal year-end falls in the period from March to June and 0 otherwise) as proxies for audit quality. I also use a RNAF variable (as measured by the ratio of non-audit fees to total fees paid) and a C_AUDITOR dummy variable (that equals 1 if a client firm changes its audit firm and 0 otherwise) as proxies for auditor independence in relation to the level of DACCs.

The empirical results summarised in the thesis show that the level of DACCs is significantly and negatively associated with the BIG4 and AOFFICE variables. This result is consistent with the common perception that higher quality auditors will lead to a higher audit quality and that this in turn will reduce level of DACCs. I also find a positive and statistically significant relationship between the FISCAL variable and the level of DACCs. This result indicates that DACCs are likely to be higher if the 
audit is conducted during the busy audit season. The empirical results summarised in the thesis also show a positive and significant relationship between the audit opinion (AO) variable and the level of DACCs. This means that a qualified or conditional audit opinion is more likely to occur if the financial statements involve a relatively higher level of DACCs. However, the empirical results summarised in the thesis report an insignificant relationship between the level of DACCs and the C_AUDITOR and RNAF variables. These results mean that auditor independence does not appear to have any impact on the level of DACCs.

In part two of this thesis, I examine whether the level of DACCs in the current year is associated with the level of the audit fee in the next ensuing year. Here it is well known that each year the auditor will review both the general and specific factors affecting their audit responsibilities in relation to a particular audit client. Hence, the agreed audit fee for the next ensuing year is likely to reflect information about the level of earnings management in prior years and of how the issues arising out of these earnings management procedures have been resolved between the client firm and the audit firm. In order to test this hypotheses, I employ the audit fee model of Simunic (1980) as refined by Choi et al. (2009), Francis and Simon (1987), Hay et al. (2006b) and Menon and Williams (2001). As expected, the second set of empirical results summarised in the thesis show a positive and statistically significant relationship between the level of DACCs in the current year and the level of the audit fee in the next ensuing year. This means that a high level of DACCs in the current year will impact positively on the level of the audit fee in the next ensuing year. 


\section{CHAPTER 1 \\ INTRODUCTION}

\subsection{Introduction}

The demand for external audit services derives from the agency issues which arise out of the separation of the ownership and control of firms. Firms are invariably owned by disparate shareholders but the "day to day" operations of the firm are controlled by professional managers who may or may not hold a significant shareholding in the firm. This means that the shareholders of the firm have a residual claim on the firm's resources and that the managers of the firm will have to communicate their stewardship of the firm's resources to its shareholders, normally by the periodic issue of a set of financial statements (Levitt 2000). In order to ensure that the financial statements published by firms are a reliable source of information for users, it is normally required that they are assessed by an auditor - an objective and rigorous third party who performs independent examinations that give financial statements credibility with users. However, recent financial crises along with numerous audit failures have raised the question of auditor competence and independence. This has prompted a plethora of research into the nature of auditor quality, auditor independence and its relationship to the quality of the audit reports appearing in published financial statements. The research summarised in this thesis seeks to contribute to this debate by focusing on two research issues of particular importance to the New Zealand economy. First, the thesis examines the impact of audit factors (such as auditor quality and auditor independence) on the level of earnings management. Second, the thesis empirically assesses the relationship between the level of earnings management and the audit fees charged by audit firms. 


\subsection{Fundamental Research Questions}

The primary motivation for this thesis arises out of the fact that whilst the relationship between audit factors and earnings management has been widely studied in many advanced industrialised countries there is only a limited volume of research that focuses on these relationships in a New Zealand context. Although the audit market in New Zealand shares many of the common features found in the audit markets of other advanced industrialised countries it also has some unique characteristics of its own. First, Hay and Jeter (2011) and Knechel et al. (2012) note that the New Zealand audit market is relatively small, is dominated by the Big 4 audit firms and is concentrated in the two major cities of Auckland and Wellington. The fact that the large majority of audit engagements are conducted out of the two major provincial cities in New Zealand has important implications for the quality of the audit procedures employed by New Zealand audit firms. Second, most public listed companies in New Zealand have a fiscal year end that occurs in a narrow window covering the period from March through to June. This in turn means that audit firms experience a busy audit season over this period when they must complete a relatively high number of audit engagements over a very limited period of time. The busy audit season is typically associated with auditor stress and burnout that reduces auditor efficiency with consequent effects for the quality of the audit work conducted by New Zealand audit firms. Unfortunately, there is no research available in New Zealand that addresses the impact that the busy audit season can have on the quality of the audit work conducted by New Zealand audit firms. This thesis, therefore, makes an empirical assessment of the quality of audit work conducted during the busy audit season in New Zealand in comparison to the quality of audit work conducted outside of this busy audit period. Third, due to the relatively small number of companies that are listed on the New 
Zealand Stock Exchange, when a conflict arises between a publicly listed company in New Zealand and its auditors it typically attracts considerable attention from shareholders, investors and the general public. This in turn raises the question as to whether auditors in New Zealand have a tendency to avoid issuing qualified (or conditional) audit opinions and/or resigning from inherently risky audit engagements in order to minimise the adverse public exposure and the litigation risks associated with these decisions. Fourthly, I would also note that the relatively low private litigation environment in New Zealand provides incentives for New Zealand audit firms to be less meticulous about insuring the quality of their audit procedures and their audit independence. This raises the question as to whether auditor independence in New Zealand (as measured by the ratio of non-audit services to the total fees paid by a particular audit client) will impair audit quality (as measured by the level of earnings management and in particular, the level of DACCs). Given this, my first major objective in this thesis is to empirically investigate the relationships which exist between the quality of the audit reports issued by New Zealand audit firms and the unique features that characterise the New Zealand audit market.

Here the prior research of the area tends to focus on the impact that a single unique audit factor has on the level of discretionary accruals booked by client firms. In contrast, the approach taken in this thesis is to examine the joint impact that a (combined) set of these audit factors will have on the level of discretionary accruals and therefore, the earnings management practices of publicly listed companies in New Zealand. In particular, the first part of this thesis undertakes an empirical study based on New Zealand data which jointly addresses the following specific research questions: 
1. Do Big 4 New Zealand audit firms provide higher quality audits than nonBig 4 New Zealand audit firms?

2. Do the offices of audit firms located in either Auckland or Wellington provide higher quality audits than audit offices located in other New Zealand towns and cities?

3. Do audits conducted in the audit busy season have lower audit quality?

4. Does a change in auditor reduce audit quality?

5. Do qualified or conditional audit opinions have a significant impact on subsequent levels of earnings management (as measured by the level of DACCs)?

6. Does a lack of auditor independence (as measured by the ratio of non-audit services to the total fees paid by a particular audit client) reduce audit quality (as measured by the level of DACCs)?

A second major objective of this thesis is to empirically investigate the impact that the earnings management practices of publicly listed companies in New Zealand have on the level of audit fees charged by New Zealand audit firms. Here my analysis is based on the premise that accounting accruals are a major factor in the determination of inherent audit risk and as such, have a significant impact on the audit procedures implemented and the audit fees charged by audit firms (Francis and Krishnan 1999; DeFond and Subramanyam 1998; Abbott et al. 2006). In particular, my empirical analysis is motivated by the fact that every year the auditor will review both the general and specific factors affecting their audit responsibilities in relation to a given audit client. They will then determine what they consider to be an appropriate level of audit fee for the next ensuing year. Likewise, the senior management in conjunction the audit committee of the particular audit client will determine what they consider an appropriate audit fee for 
the next ensuing year. Then by a process of bargaining and gaming the audit client and audit firm will come to an agreement about the level of the audit fee to be paid in the next ensuing year. The gaming aspect of the negotiations will be based on the way the auditor has resolved the accounting and auditing issues that have arisen during the previous year's audit as well as the expressed intentions of the audit firm and desires of the audit client about the way the audit ought to be conducted and the audit and accounting issues resolved in the next ensuing year. Hence, the agreed audit fee for the next ensuing year is likely to reflect information about the level of earnings management in prior years and of how the issues arising out of these earnings management issues have been resolved between the client firm and the audit firm.

\subsection{Research Methodology and Data}

The empirical work summarised in this thesis uses the absolute magnitude of discretionary accruals (that is, DACCs) as a proxy for earnings management. DACCs are estimated for each firm comprising my sample using the modified Jones (1991) model as developed by Dechow et al. (1995). Moreover, several auditor characteristics have been employed in the thesis as proxies for auditor quality and auditor independence. Thus, the empirical work summarised in the thesis uses a BIG4 dummy variable (that equals 1 if the auditor is a Big 4 audit firm and 0 otherwise), an AOFFICE dummy variable (that equals 1 if the audit firm's office is located in Wellington or Auckland and 0 otherwise) and an AO dummy variable (that equals 1 if the client firm receives a qualified or conditional audit opinion and 0 otherwise) as proxies for audit quality. The empirical work summarised in the thesis also uses a FISCAL dummy variable (that equals 1 if the client firm's fiscal year-end falls in the period from March to June and 0 otherwise) to examine the impact of the busy audit season on the level of DACCs. Here I have 
previously noted that the busy audit season is normally associated with problems of auditor stress and burnout that in turn may reduce the level of auditor efficiency. The thesis employs a RNAF variable (as measured by the ratio of non-audit fees to total fees paid) and a C_AUDITOR dummy variable (that equals 1 if a client firm changes its audit firm and 0 otherwise) as proxies for auditor independence in relation to the level of DACCs.

In order to address the research questions posed in the previous section (1.2) of this thesis, I have collected data relating to a sample of 567 firm-years listed on the New Zealand Stock Exchange and covering the period from 2006 until 2010. Two regression models are then applied to this data. First, I employ the regression procedures previously invoked by Frankel et al. (2002), Antle et al. (2006) and Cahan et al. (2008) in order to examine the impact of the aforementioned audit factors (BIG4, AOFFICE, AO, FISCAL, RNAF and C_AUDITOR) on the level of DACCs. In addition to this, however, I employ the audit fee model of Simunic (1980) as refined by Choi et al. (2009), Francis and Simon (1987), Hay et al. (2006b) and Menon and Williams (2001) to test for the impact of the level of DACCs in the current year on the level of the audit fee in the next ensuring year.

\subsection{Summary of Main Findings}

The empirical results summarised in the thesis show that the level of DACCs is significantly and negatively associated with the BIG4 and AOFFICE variables. This result is consistent with the common perception that a higher quality auditor will, as one might expect, invoke higher audit quality procedures and these in turn will reduce level of DACCs appearing in the audit client's financial statements. I also find a positive and statistically significant relationship between the FISCAL variable and the level of DACCs. This result indicates that DACCs are likely to be higher if the 
audit is conducted in the busy audit season. The empirical results summarised in the thesis also show a positive and significant relationship between the audit opinion (AO) variable and the level of DACCs. This means that a qualified or conditional audit opinion is more likely to occur if the financial statements involve a relatively higher level of DACCs. However, the empirical results summarised in the thesis report an insignificant relationship between the level of DACCs and the C_AUDITOR and RNAF variables. These results mean that a perceived lack of auditor independence does not appear to have any impact on the level of DACCs.

As expected, the second set of empirical results summarised in the thesis show a positive and statistically significant relationship between the level of DACCs in the current year and the level of the audit fee in the next ensuing year. This means that a high level of DACCs in the current year will impact positively on the level of the audit fee in the next ensuing year. As far as I am aware, this thesis provides the first empirical evidence dealing with the impact of DACCs on the level of audit fees in next ensuring year. It is an empirical result that has several important implications. First, it strongly suggests that audit fees, when taken in conjunction with other contextual factors, can provide information for policy makers, regulators, investors and other interested parties about the quality of the audit procedures employed and/or the level of auditor independence. Second, this result also provides important empirical evidence in support of the argument suggested by Behn et al. (1999) that client firm satisfaction is positively associated with the level of audit fees paid in the next ensuing year. Third, this result also confirms two crucial characteristics of the audit fee negotiation process that need to be considered by empirical researchers when formulating audit fee models: (1) audit fees are normally negotiated prior to the commencement of an audit assignment (Karen et al. 2011; Hackenbrack et al. 2011) and (2) audit fee negotiation is not a "one shot" 
negotiation procedure but is repeated each and every year. This in turn raises the possibility that relatively high DACCs in any given year may continue to have an impact on the audit fee paid by a client firm for several years into the future and not just in the current year as assumed by the large majority of audit fee models appearing in the literature.

\subsection{Structure of the Thesis}

The thesis comprises seven chapters. I now provide a brief summary of the salient features of each of these chapters.

\section{Chapter 2: Literature Review}

Chapter two reviews the literature relevant to earnings management and its relationship with the audit factors identified in the thesis. The chapter opens with a consideration of the definitions of earnings management that are to be found in the prior literature of the area as well as the incentives that firm management have to implement earnings manipulation procedures. My overall conclusion is that earnings management has normally been implemented by manipulating the discretionary accruals component of the earnings figure which appears in a firm's published financial statements. After clarifying the differences between real activities manipulation and accruals manipulation, section 2.1 summarises the eight most popular models which have been employed to estimate the discretionary accruals component of a firm's reported earnings figure. These are the Healy (1985) model, the DeAngelo (1986) model, the Jones (1991) model, the modified Jones (1991) model as developed by Dechow et al. (1995), the forwardlooking model of Dechow et al. (2003), the Dechow and Dichev (2002) model, the McNichols (2002) model and the Kothari et al. (2005) model. Section 2.2 then goes on to summarise recent studies that address the relationship between 
audit factors and the level of DACCs. Finally, section 2.3 summarises an emerging literature that relates the level of DACCs in the current year to the audit fees paid in subsequent years. My summary of the literature in this chapter has three main implications: (1) the current empirical evidence that deals with the relationship between audit factors and the level discretionary accruals is generally conflicting and inconsistent; (2) there is only a very limited volume of research that deals with the relationship between audit factors and the level of DACCs in a New Zealand context and (3) current empirical evidence dealing with the relationship between DACCs and audit fees is afflicted by serious methodological issues and potential biases (Antle et al. 2006).

\section{Chapter 3: Research Setting in New Zealand}

Chapter three summarises the status of audit research in New Zealand. The chapter begins in Section 3.1 by providing a brief summary of the New Zealand audit market's principal characteristics. I note in particular that whilst the New Zealand audit market has much in common with the audit markets of other advanced industrialised countries, it also has some unique characteristics of its own. Section 3.2 then goes on to discuss the New Zealand audit legislative environment and of how it provides a unique setting for those who wish to conduct empirical research dealing with the relationship between audit factors and earnings management. Sections 3.3 and 3.4 summarise the New Zealand audit regulations relating to nonaudit services; the procedures relating to the appointment and replacement of auditors; regulations relating to the proper conduct of audit fee negotiations; regulations relating to the issue and content of audit opinions; and New Zealand Stock Exchange. These regulations enshrine several key differences between the New Zealand audit environment and that which prevails in other advanced industrialised countries. 


\section{Chapter 4: Hypotheses Development}

This chapter uses the summary of the literature provided in Chapter two of the thesis and the summary of the New Zealand research setting provided in Chapter three to formulate hypotheses about the relationship between the audit factors identified in the literature and the level of DACCs which one would expect to find in a New Zealand context. Specifically, the hypotheses I formulate in this chapter address the potential impact of six important audit factors - (1) Big 4 auditors; (2) Location of audit office; (3) Audit busy season; (4) Non-audit service; (5) Auditor change, and (6) Audit opinion - on the level of DACCs. Moreover, Section 4.2 of this chapter develops an important hypothesis that relates the level of DACCs in the current year to the audit fees paid by client firms in subsequent years.

\section{Chapter 5: Data and Research Methodology}

In chapter 5 I describe the database and research methodology employed in the thesis. Section 5.1 explains the procedures used to select the data on which the empirical analysis in the thesis is based. In particular, the sample used in the thesis is comprised of 567 firm-years listed on the New Zealand Stock Exchange and covering the period from 2006 until 2010. Moreover, Section 5.2 gives a detailed summary of the modified Jones (1991) model since this is the principal model used to estimate the discretionary accruals on which the empirical analysis in this thesis is based. Finally, section 5.3 formulates the two principal empirical models that are employed to test the hypotheses developed in Chapter 4.

\section{Chapter 6: Empirical Results}

Chapter six summarises the important results obtained in the empirical work on which this thesis is based. Thus, section 6.1 opens with summary descriptive 
statistics for the data on which the empirical work is based. Section 6.2 provides a summary of the empirical results obtained for the two principal empirical models that are used to test the hypotheses formulated in chapter 4 . These hypotheses are concerned with the relationship between the audit factors identified in this thesis, the level of DACCs and the impact of DACCs on the magnitude of future audit fees. Sections 6.3 summarises several robustness and sensitivity tests relating to the empirical procedures employed in this chapter.

\section{Chapter 7: Summary and Concluding Discussions}

Chapter seven provides an overall summary of the conclusions obtained from the empirical work contained in the thesis and discusses their implications for regulators, users of published financial statements and client firm managers. Moreover, this chapter also outlines the major limitations associated with the empirical work summarised in the thesis and provides some suggestions for future research work. 


\section{CHAPTER 2 \\ LITERATURE REVIEW}

In this chapter I review the literature relevant to earnings management and its relationship with the audit factors identified in the previous chapter of this thesis. I start with a consideration of the definitions of earnings management that are to be found in the prior literature of the area as well as the incentives that firm management have to implement earnings manipulation procedures. My main purpose here is to emphasise that not all earnings manipulation is misleading and that it can often be difficult to distinguish between earnings manipulation that ultimately proves to be fraudulent and the on-going actions of management to keep costs within budgets or to get revenues to meet desired target levels. Given this, in section $2.1 \mathrm{I}$ spend considerable time clarifying the differences between real activities manipulation and accruals manipulation and then go on to summarise the eight most popular models employed in the literature for estimating the discretionary accruals component of a firm's reported earnings figure.

In section 2.2, I summarise recent studies that address the impact of audit factors on the level of DACCs. I start by noting that an auditor's principal function is to reduce the information asymmetries that exist between the managers of a client firm and the stakeholders of the firm by ensuring that the client firm's financial statements provide a "true and fair" view of the firm's financial position. Thus, section 2.2 summarises recent research that investigates the impact of six important audit factors on the level of DACCs. These factors are: (1) whether the audit is conducted by a Big 4 audit firm; (2) the location of the audit office; (3) the provision of non-audit services; (4) whether the audit is conducted during the busy audit season; (5) whether the client firm changes auditor, and (6) whether the client firm receives a qualified or conditional audit opinion. Finally, section 2.3 
summarises an emerging literature that relates the level of DACCs in the current year to the audit fees paid in subsequent years. This contrasts with the pre-existing literature in the area which is normally based on the premise that DACCs are related to accounting items that require a significant level of audit judgment in the current year. This in turn will mean that high levels of DACCs will impact on the degree of audit risk and will lead to more audit effort and to an increased level of audit fees in the current year (that is, contemporaneous to the conduct of the audit) (Fatima 2011; Gul et al. 2003; Abbott et al. 2006). Hence, the vast majority of the empirical work conducted in this area examines the contemporaneous relationship between DACCs and audit fees. This contrasts with a fundamental proposition on which this thesis is based; namely, that future audit fees are likely to reflect information about the level of earnings management in prior years and of how the issues arising out of these earnings management procedures have been resolved between the client firm and the audit firm.

It is also unfortunate that much of the pre-existing literature in this area is afflicted by two methodological deficiencies (Antle et al. 2006). For a start, earnings management is an endogenous variable in most of the audit fee models which appear in the literature (Antle et al. 2006). On the one hand, the detection of earnings management will increase audit effort. If, however, an auditor increases their audit effort, it is likely that they will detect even more earnings management. This in turn will reduce the earnings management risk associated with the client firm's audited financial statements. Thus, in a regression of audit fees on discretionary accruals, the level of the discretionary accruals will be correlated with the error term in the regression equation and this will lead to biased estimates of parameter values. Section 2.3, therefore, concludes this chapter with a discussion of these and other significant econometric issues that afflict most of the pre-existing literature in the audit fees area. 


\subsection{Earnings Management}

\subsubsection{Definitions of Earnings Management}

Earnings or net income is one of the most important items in a firm's financial statements since it provides a signal for investors, shareholders, analysts and other interested parties about the underlying intrinsic or fundamental value of a company's equity. The earnings figure also provides valuable information about the performance of the firm's management. Given this, it is no surprise that the managers of firms pay considerable attention to the accounting policies applied in determining a firm's earnings as well as to how its earnings are reported in the public domain. There will inevitably be an element of self interest in this process because the benefits that accrue to both a firm's management and its shareholders will normally hinge on the earnings figure reported by the firm. Earnings management, therefore, can be defined as Schipper (1989, p. 92):

“... a purposeful intervention in the external financial reporting process, with the intent of obtaining some private gain (as opposed to, say, merely facilitating the neutral operation of the process)."

Furthermore, Healy and Wahlen (1999, p. 368) suggest that earnings management occurs:

“... when managers use judgment in financial reporting and in structuring transactions to alter financial reports to either mislead some stakeholders about the underlying economic performance of the company or to influence contractual outcomes that depend on reported accounting numbers."

However, Ronen and Yaari (2007) argue that these definitions are inadequate because they do not distinguish clearly between earnings management and the impact which the firm's "normal" commercial activities can have on the earnings figure reported by the firm. For example, Ronen and Yaari (2007) argue that not all earnings management is misleading and that it is difficult to distinguish between 
earnings manipulation that ultimately proves to be fraudulent and the day-to-day struggles of management to keep costs within budgets or to get revenues to meet desired sales targets. Given this, Ronen and Yaari (2007) suggest that the accounting procedures and practices endorsed by a firm's management may be classified into one of three groups in terms of the impact they have on the earnings figure ultimately reported by the firm; namely: (i) beneficial earnings management; (ii) pernicious earnings management and (iii) neutral earnings management. They summarise the important attributes of each group of accounting procedures and practices in the following table:

Table 2.1: Classification of Earnings Management of Ronen and Yaari (2007)

\begin{tabular}{|c|c|c|c|}
\hline & $\begin{array}{c}\text { Beneficial } \\
\text { earnings } \\
\text { management }\end{array}$ & $\begin{array}{l}\text { Neutral earnings } \\
\text { management }\end{array}$ & $\begin{array}{l}\text { Pernicious earnings } \\
\text { management }\end{array}$ \\
\hline Definition & $\begin{array}{l}\text { Earnings management } \\
\text { is taking advantage of } \\
\text { the flexibility in the } \\
\text { choice of accounting } \\
\text { treatment to signal the } \\
\text { manager's private } \\
\text { information on future } \\
\text { cash flows }\end{array}$ & $\begin{array}{l}\text { Earnings management } \\
\text { is choosing an } \\
\text { accounting treatment } \\
\text { that is either } \\
\text { opportunistic } \\
\text { (maximizing the utility } \\
\text { of management only) } \\
\text { or economically } \\
\text { efficient }\end{array}$ & $\begin{array}{l}\text { Earnings } \\
\text { management is the } \\
\text { practice of using } \\
\text { tricks to } \\
\text { misrepresent or } \\
\text { reduce the } \\
\text { transparency of } \\
\text { financial reports }\end{array}$ \\
\hline $\begin{array}{l}\text { Impact on } \\
\text { accounting } \\
\text { reports }\end{array}$ & $\begin{array}{l}\text { Enhances the } \\
\text { transparency of } \\
\text { reports }\end{array}$ & $\begin{array}{l}\text { Either opportunistic or } \\
\text { efficiency enhancing }\end{array}$ & $\begin{array}{l}\text { Outright } \\
\text { misrepresentation } \\
\text { and fraud }\end{array}$ \\
\hline $\begin{array}{l}\text { Supported } \\
\text { by }\end{array}$ & $\begin{array}{l}\text { Ronen and Sadan } \\
(1981) \text {, Demski, Patell } \\
\text { and Wolfson (1984), } \\
\text { Suh (1990), Demski } \\
(1998), \text { Beneish } \\
(2001) \text {, Sankar and } \\
\text { Subramanyam (2001). }\end{array}$ & $\begin{array}{l}\text { Fields, Lys and } \\
\text { Vincent (2001), } \\
\text { Scott (2003). }\end{array}$ & $\begin{array}{l}\text { Schipper (1989), } \\
\text { Levitt (1998), Healy } \\
\text { and Wahlen (1999), } \\
\text { Tzur and Yaari } \\
\text { (1999) , Chtourou, } \\
\text { Bedard and Courteau } \\
\text { (2001), Miller and } \\
\text { Bahnson (2002), } \\
\text { Dechow (2004). }\end{array}$ \\
\hline
\end{tabular}


Similarly, Giroux (2004) suggests an alternative classification of the impact which the accounting procedures and practices endorsed by a firm's management can have on the earnings figure reported by the firm. These are (i) that a particular accounting procedure will lead to conservative accounting under which a firm's reported earnings incorporate all current and anticipated losses but do not include any anticipated gains; (ii) moderate accounting under which the reported earnings figure is an accurate reflection of the firm's commercial activities; (iii) aggressive accounting under which there is a pre-disposition to report an earnings figure that where legally possible, includes all anticipated gains and (iv) fraudulent accounting which involves the deliberate falsification of the firm's reported earnings. The Giroux (2004) classification of the impact that a firm's accounting procedures and practices can have on the reported earnings figure may be summarised in the following diagram:

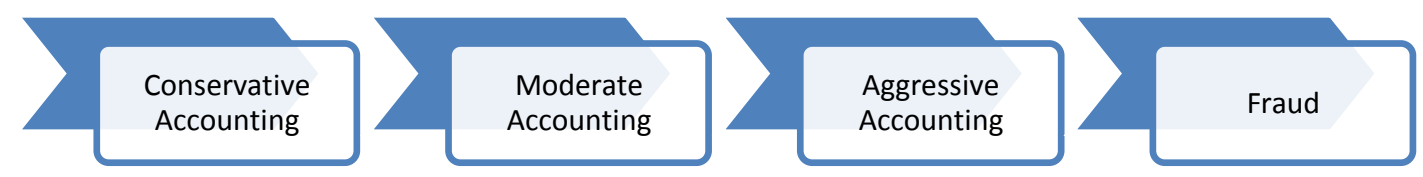

Taken together, the classification schemes of Giroux (2004) and Ronen and Yaari (2007) suggest that one can catalogue the accounting procedures and practices endorsed by a firm's management as either leading to an increased level of transparency in the earnings figure reported by the firm or the manipulation of the reported earnings figure for the purposes of private management gain.

\subsubsection{Incentives for Earnings Management}

I note above how earnings management encompasses the adoption of accounting practices and procedures that lead to the intentional manipulation on the part of a firm's management of the earnings figure reported in the firm's financial 
statements. Dechow et al. (1996) investigate 39 Accounting and Auditing Enforcement Releases (AAERs) against individuals or firms in the United State (U.S.) that were issued by the Securities and Exchange Commission over the period from 1982 until 1992 and which deal either directly or indirectly with the manipulation of a firm's reported earnings. As seen from Table 2.2, issuing securities and insider trading is the most common incentive for earnings management across the AAERs examined by Dechow et al. (1996) with around 57\% of explanations. The second most common incentive arises from managers manipulating earnings in order to meet the expectations of analysts and investors; this accounts for $23 \%$ of earnings management explanations. Third, earnings-based bonuses for management contribute around $14 \%$ of the reasons for earnings manipulations.

Table 2.2. Motivations for Earnings Management Discussed in 39 AAERs

\begin{tabular}{|l|c|c|}
\hline \multicolumn{1}{|c|}{ Explanations } & Number & Rate \\
\hline Issue Securities or Insider Trading & 28 & $57 \%$ \\
\hline Upwardly Trending earnings per share & 11 & $23 \%$ \\
\hline Earnings-based Bonuses & 7 & $14 \%$ \\
\hline Others & 3 & $6 \%$ \\
\hline \multicolumn{1}{|c|}{ Total } & $\mathbf{4 9}^{(*)}$ & $100 \%$ \\
\hline
\end{tabular}

${ }^{(*)}$ There are 8 firms that have more than one explanation

Source: Dechow et al. (1996)

I now discuss in further detail the three principal incentives for the manipulation of the reported earnings figures identified from the AAERs by Dechow et al. (1996).

\subsubsection{Issuing Securities and Insider Trading}

I begin by noting that the managers of a firm have incentives to manipulate the firm's earnings in the short term in order to benefit from potential movements in 
the price of the firm's stock. Here Dechow and Schrand (2004) suggest that earnings manipulation may be of a form that results in both decreases and increases in the price of a firm's stock. For example, firms typically manipulate earnings in order to increase the stock price in the short term in order to reduce the cost of acquiring new capital or the effective price of an acquisition. In contrast, management buyouts create incentives for managers to manipulate earnings in order to decrease the price of a firm's stock thereby reducing the buyout price. Therefore capital market incentives for earnings management need to be considered in the context of a particular firm and the specific circumstances faced by the firm and its managers.

First, recent studies document that managers have incentives to manipulate earnings to increase stock prices prior to seasoned equity offerings (Rangan 1998; Teoh et al. 1998; Cohen and Zarowin 2010; Yoon and Miller 2002). In particular, Rangan (1998) used a U.S. sample of 230 seasoned equity offerings (SEO) which occurred over the period from 1987 until 1990 whilst Cohen and Zarowin (2010) employed a U.S. sample of 1,511 SEOs covering the period from 1987 until 2006. Both studies find that discretionary accruals during the year around the SEOs are negatively correlated with earnings changes in the following year. Similarly, Yoon and Miller (2002) use a modified discretionary accruals model based on a sample of 249 Korean SEOs covering the period from 1995 until 1997 and find that Korean firms contemplating an SEO in the next ensuing year manipulate their earnings in the current year, particularly when their relative performances are poor.

Likewise, initial public offerings (IPO) provide similar incentives for earnings management to SEOs. Dechow and Schrand (2004) and Roosenboom et al. (2003) hypothesise that the relationship between IPOs and earnings management is even stronger than the relationship between SEOs and earnings management because the amount of publicly available historical financial information is smaller for IPOs 
than is the case for SEOs. Despite this, however, recent earnings management studies based on the earnings figures of IPOs report mixed results on this hypothesis. Chen et al. (2005), DuCharme et al. (2001), DuCharme et al. (2004), Roosenboom et al. (2003) and (Teoh et al. 1998) report evidence that IPOs firms manage their earnings upwards through income-increasing accruals to increase offering proceeds. In contrast, Aharony et al. (1993) and Ahmad-Zaluki et al. (2011) do not find strong evidence that IPO firms seek to increase reported earnings through income-increasing accruals. In particular, Ahmad-Zaluki et al. (2011) use a sample of 250 Malaysian IPOs covering the period from 1990 until 2000 and find that the positive relationship between IPOs and income increasing accruals is mainly driven by IPOs during the East Asian financial crisis of 1997 and 1998 and reflects the requirement for many firms to provide profit guarantees during this period. Ahmad-Zaluki et al. (2011) conclude that income-increasing earnings management is not a general phenomenon over the majority of the period covering their empirical analysis.

Third, in a management buyout, managers have incentives to lower the purchase price, potentially through income-decreasing earnings management that will have a negative impact on the firm's stock price (Dechow and Schrand 2004; Perry and Williams 1994). However, again recent empirical research is not compatible with this hypothesis. DeAngelo (1986) investigates the accounting policy decisions made by managers of 64 U.S. firms covering the period from 1973 until 1982 who proposed to purchase all publicly-held common stock and "go private". DeAngelo (1986) does not find any significant evidence that managers of the sample firms systematically understate earnings in the period before a management buyout of public stockholders. In contrast, Perry and Williams (1994), employ a sample of 175 U.S. buyouts covering the period from 1981 until 1988 and use a different methodology for identifying the abnormal accruals comprising a firm's reported 
earnings. Specifically, Perry and Williams (1994) use the regression-based expectations model developed by Jones (1991) to determine each firm's abnormal accruals. In contrast, DeAngelo (1986) assumes that a firm's abnormal accruals evolve in terms of a random walk. Using the Jones (1991) regression-based expectations model of abnormal accruals, however, Perry and Williams (1994) find compelling evidence of downward earnings manipulation in the year preceding the public announcement of management's intention to bid for control of the company. Similarly, Wu (1997) uses a sample of 87 U.S. management buyouts covering the period from 1980 until 1987. Wu (1997) employs industry-adjusted changes in earnings to detect evidence of earnings management in the year prior to the management buyout and finds compelling evidence of downward earnings manipulation in the year prior to the management buyout proposal.

Fourth, Sawicki and Shrestha (2008) argue that insiders (for example, directors and managers) are in a better position to get information about their firms' value than outsiders and are thus able to use this information to implement profitable trading strategies in the firm's shares. Sawicki and Shrestha (2008) employ a U.S. sample comprised of 47,666 firm-year observations covering the period from 1991 until 2004 and report strong evidence of insiders managing earnings downwards when buying shares and managing earnings upwards when selling shares. Moreover, Beneish et al. (2012) employ a U.S. sample of 462 firms that experienced technical default in the period from 1983 until 1997 and finds that the abnormal accruals comprising their reported earnings increase their return on assets (ROA) measure by an average of $3 \%$ per annum.

\subsubsection{Upwardly Trending Earnings per Share}

The ability to smooth income also provides potential incentives for firms to manage earnings in order to meet or beat a given target (Dechow and Schrand 
2004). Here empirical researchers have identified two potential earnings thresholds. The first of these involves the firm avoiding losses; that is, the firm need only report a positive profit, no matter how small it might be. This threshold arises from a psychological notion that investors and shareholders prefer a positive, rather than a negative income number (Burgstahler and Dichev 1997; Ronen and Yaari 2007). In particular, Durtschi and Easton (2005) show that the market prices firms reporting a positive profit differently to the way it prices firms reporting a loss. Using U.S data drawn from the 2002 Annual Industrial and Research Compustat files, Durtschi and Easton (2005) report that the median price of a unit of stock for firms reporting a one-cent profit is $\$ 1.31$, whereas the median price of a unit of stock for firms reporting a one-cent loss is $\$ 0.25$. Support for this empirical phenomenon is also to be found in the work of Hayn (1995) and Burgstahler and Dichev (1997) amongst others who show that the number of firms who report an earnings figure just above zero far exceeds the number of firms who report an earnings figure just below zero. However, it is unclear whether the positive profit phenomenon observed by Durtschi and Easton (2005), Burgstahler and Dichev (1997) and Hayn (1995) amongst others is due to firms manipulating their earnings in order to report a positive profit or to some other reason.

Charoenwong and Jiraporn (2009) use a sample of all Singapore and Thai listed firms and financial institutions from 1975 until 2003. They show that whilst there is significant evidence of earnings management in order to eliminate losses and report zero or positive profits in Singaporean non-financial firms and all Thai firms, there is no evidence of profit manipulation for Singaporean financial firms. Similarly, Burgstahler and Dichev (1997) use a U.S. sample of 64,466 firm-years covering the period from 1977 until 1994 and provide evidence that firms manage reported earnings to avoid losses. Specifically, Burgstahler and Dichev (1997) indicate that that $8 \%$ to $12 \%$ of firms with small pre-managed earnings decreases, 
manipulate their earnings in order to report an increase in their profits. Similarly, $30 \%$ to $44 \%$ of firms with slightly negative pre-managed earnings again manipulate their earnings in order to report a positive earnings figure. However, this contrasts with the results reported by Coulton et al. (2005) using data for Australian firms covering the period from 1993 until 2002 that rejects the hypothesis that firms with slightly negative pre-managed earnings or negative earnings changes manipulate their earnings in order to report a positive earnings figure or a positive earnings change. Here Dechow et al. (2003) provide an example which shows that managers and employees have incentives to simply work harder to improve firm performance if they know that they are close to the zero earnings threshold and so, it is unlikely that firms which report small positive earnings will have manipulated their earnings figure in order to insure that they can report a positive profit. Moreover, Beaver et al. (2003) show that the asymmetrical tax treatment of profits and losses and conservatism related to the reporting of special items may also cause a "kink" in the earnings measure around zero.

The second earnings threshold is more demanding and requires that the firm should report an earnings figure that is either comparable with or exceeds the earnings figures it has reported in the recent past or that the firm reports an earnings figure which meets analysts' expectations (e.g, Ronen and Yaari 2007). Dechow and Schrand (2004) suggest two reasons why managers might manipulate earnings in order to meet or slightly exceed analysts' forecasts or the earnings figures the firm has reported in the recent past. First, there may be higher benefits in terms of remuneration and perquisites for managers of firms which exceed rather than just meet analyst forecasts or the earnings figures reported in the recent past. Second, due to the uncertainty of earnings outcomes, firms may prefer to report a small positive, rather than zero earnings surprise. Consistent with the results summarised by Bartov et al. (2002), Kasznik and McNichols (2002) and Lopez and Rees (2002), 
Burgstahler and Eames (2006) present evidence of positive market responses for firms which meet or slightly exceed analyst earnings forecasts. In particular, Burgstahler and Eames (2006) provide evidence that firms which meet or slightly exceed analyst earnings forecasts, tend either to manipulate their earnings upward or manipulate the earnings forecast downwards. Similarly, Dechow and Schrand (2004) argue that firms also prefer to avoid reporting decreases in earnings relative to the earnings announced in the same quarter in the previous year. Graham et al. (2005) use a combination of survey methods and interviews based on more than 400 Chief Financial Officers in the U.S. and conclude that a surprising $78 \%$ of their sample admits to sacrificing long-term value in order to smooth the reported earnings figure.

\subsubsection{Earnings-based Bonuses}

Executive compensation schemes invariably comprise an earnings-based component in order to provide incentives for a firm's management to maximise the market value of the firm's stock (Healy 1985). However, such schemes also create incentives for corporate executives to manipulate earnings in order to increase the value of their remuneration packages. Healy (1985) examines a sample of 94 U.S. firms selected from the 250 largest U.S. industrial corporations as summarised in the 1980 Fortune Directory. Using this sample, Healy (1985) finds that bonus schemes create incentives for managers to select accounting procedures that maximize the value of their bonus awards. In particular, Healy (1985) finds that managers are more likely to choose income-decreasing accruals when their bonus plan upper or lower bounds are binding, and income-increasing accruals when these bounds are not binding. Holthausen et al. (1995) extends the work of Healy (1985) by using confidential data relating to executive-specific short-term bonus plans covering the period the period from 1982 until 1991. Holthausen et al. (1995) report similar evidence to Healy (1985) in that managers manipulate earnings 
downwards when their bonuses are at their maximum. However, they find no evidence that managers manipulate earnings downwards when earnings are below the minimum necessary to receive any bonus. Holthausen et al. (1995) argue that Healy's results at the lower bound are an artefact of the particular methodology he uses to estimate a firm's discretionary accruals. Once Holthausen et al. (1995) adjust Healy's methodology to provide a more accurate estimate of a firm's discretionary accruals Holthausen et al. (1995) find no compelling evidence that managers manipulate earnings downwards when earnings are below the minimum threshold necessary to receive a bonus payment.

\subsubsection{The Methods of Earnings Management}

Earnings comprise cash flows and accruals and so, recent researchers typically suggest two corresponding methods to manipulate earnings: (i) real activities manipulation and (ii) accruals manipulation (Dechow and Schrand 2004; Roychowdhury 2006).

\subsubsection{Real Activities Manipulation}

A number of recent studies have shown that managers have incentives to manipulate financial statements not only through the use of discretionary accruals, but also through their operational decisions (Healy and Wahlen (1999), Dechow and Schrand (2004), Fudenberg and Tirole (1995) and Roychowdhury (2006)). Roychowdhury (2006), for example, points out that real activities such as the acceleration (that is, the bringing forward) of sales transactions, the alteration of shipment schedules, and the delaying of research and development (R\&D) and maintenance expenditures can have a significant impact on a firm's reported earnings. Roychowdhury (2006, p. 337) then defines real activities manipulation in the following terms: 
“... departures from normal operational practices, motivated by managers' desire to mislead at least some stakeholders into believing certain financial reporting goals have been met in the normal course of operations."

I have previously noted (as in section 2.1.2.2) how Graham et al. (2005) use a combination of survey methods and interviews based on more than 400 Chief Financial Officers in the U.S. These survey results show that chief financial officers are willing to manipulate real activities in order to meet pre-specified earnings targets rather than to manipulate the earnings figure itself. They show in particular that around $80 \%$ of the chief financial officers interviewed agree or strongly agree that firms should decrease discretionary spending (e.g. R\&D, advertising, maintenance, etc.) in order to meet a pre-specified earnings target. Moreover, over 55\% of the chief financial officers interviewed agreed that they would delay starting a new project even if this entails a small sacrifice in value in order to insure that they meet a pre-specified earnings target. There were also several other real activities and discretionary accrual manipulations that chief financial officers would be prepared to enter into in varying degrees in order to meet a pre-specified earnings target, as summarised in the following figure: 
Figure 2.1: Other Real Activities and Discretionary Accrual Manipulations

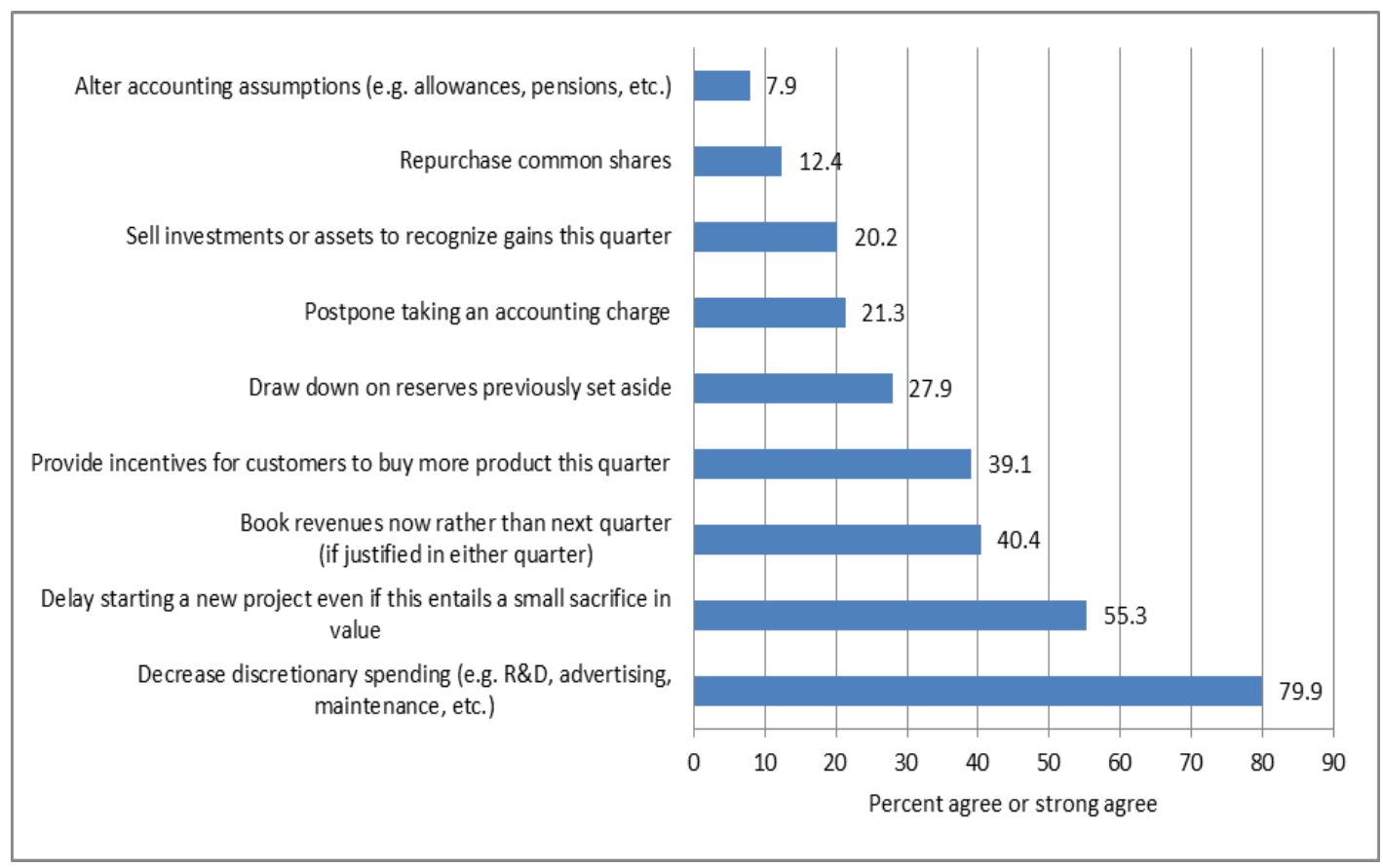

(Responses to the question: "Near the end of the quarter, it looks like your company might come in below the desired earnings target. Within what is permitted by GAAP, which of the following choices might your company make?" based on the Graham et al. (2005, p. 35) survey of 401 financial executives)

Similarly, several other empirical studies have found that firm managers are prepared to manipulate the reported earnings figure through real activities manipulation. Bens et al. (2002) find evidence that firms shift resources away from real investments towards the repurchase of their own stock when there is a significant increase in the number of employees who exercise their stock options. Moreover, Baber et al. (1991), Bushee (1998) and Dechow and Sloan (1991) document that managers are likely to manipulate $\mathrm{R} \& \mathrm{D}$ expenditures in order to meet their earnings benchmarks. For example, Dechow and Sloan (1991) summarise evidence that shows how CEOs reduce $R \& D$ expenditures during their final years in office in order to increase the firm's short-term earnings and thereby boost the value of their stock options in the 
lead up to retirement. Last but not least, Bartov (1993) finds evidence that managers use the timing of income recognition from disposal of long-lived assets and investments in order to manipulate the firm's earnings.

\subsubsection{Accruals Manipulation}

Accruals arise from the timing difference between the transaction event and the transfer of cash and can be implemented by either deliberate accounting selection or discretionary accounting estimations (Dechow and Schrand 2004, p. 41). Here, Watts and Zimmerman (1978) develop a positive accounting theory which suggests that managers have incentives to choose accounting policies that maximise their personal wealth. In particular, Watts and Zimmerman (1978) summarise empirical evidence which is compatible with the hypothesis that managers are motivated to choose accounting policies which will decrease the tax payments made by the firm and/or reduce the costs incurred by the firm, thereby increasing the firm's earnings and the benefits they receive under the firm's earnings related compensation plans. Likewise, Cook et al. (2011) show that manufacturing firms use different methods of inventory valuation (and in particular, the allocation of overheads in product costing) to shift fixed costs between cost of goods sold and inventory accounts, thereby managing the firm's earnings either upwards or downwards according to whether it is in the firm management's own personal interest to do so. Furthermore, Hagerman and Zmijewski (1979) summarise empirical evidence which is compatible with the hypothesis that managers choose accounting policies in relation to inventory, depreciation, and pension cost amortization in order to manipulate the firm's earnings in such a way as to increase the benefits arising under their compensation packages. There is also a steadily expanding empirical literature which shows that managers use accounting judgments in order to manipulate discretionary accruals. Here, Bishop and Eccher (2000) provide evidence that firms manage their depreciation charges (and in particular, estimates 
of the useful lives of long-lived assets) in order to manipulate the firm's earnings to their own advantage. Moreover, McNichols and Wilson (1988) and Jackson and Liu (2010) find that managers use provisioning (specifically, the provision for bad debts and/or allowances for uncollectible accounts) to manipulate corporate earnings. In particular, Jackson and Liu (2010) use U.S. data covering the period from 1980 until 2004 and show that firms manage their bad debt provisioning in order to increase reported earnings to a level where it either meets or exceeds analysts' earnings forecasts for the firm. Similarly, Shen and Huang (2011) use data relating to 441 Australian commercial banks covering the period from 1991 until 2001 and show that Australian banks manage their loan loss provisions for capital management and earnings management purposes. Shen and Huang (2011) conclude in particular that the reported earnings of Australian banks may not provide a true reflection of their underlying profitability.

\subsubsection{Measuring Earnings Management}

Current studies typically divide accruals into three elements: discretionary accruals, non-discretionary accruals and reversal accruals (Ronen and Yaari 2007; Dechow et al. 2012). Here, Ronen and Yaari (2007, p. 372) define non-discretionary accruals as:

“... accruals that arise from transactions made in the current period that are normal for the firm given its performance level and business strategy, industry conventions, macro-economic events and other economic factors. "

In contrast, Ronen and Yaari (2007, p. 372) define discretionary accruals as:

“...accruals that arise from transactions made or accounting treatments chosen in order to manage earnings." 
Finally, Ronen and Yaari (2007, p. 372) define reversal accruals as:

“... accruals originating from transactions made in previous periods.”

These definitions imply that the total accruals of firm $\mathrm{i}$ in period $\mathrm{t}$ can be broken down as follows: ${ }^{1}$

$$
\mathbf{T} \mathbf{A}_{i, t}=\mathbf{D A} \mathbf{A}_{i, t}+\mathbf{N D A}_{i, t}+\mathbf{R} \mathbf{A}_{i, t}
$$

where:

$\mathrm{TA}_{\mathrm{i}, \mathrm{t}}$ : Total accruals of firm $\mathrm{i}$ in period $\mathrm{t}$;

$\mathrm{DA}_{\mathrm{i}, \mathrm{t}}$ : Discretionary accruals of firm $\mathrm{i}$ resulting from transactions and events occurring in period $\mathrm{t}$;

$\mathrm{NDA}_{i, t}$ : Non-discretionary accruals of firm i resulting from transactions and events occurring in period $t$;

$\mathrm{RA}_{\mathrm{i}, \mathrm{t}}$ : Reversal accruals for firm $\mathrm{i}$ in period $\mathrm{t}$.

However, here empirical researchers have been unable to find a completely satisfactory methodology for distinguishing between discretionary accruals and non-discretionary accruals. Elgers et al. (2003, p. 406), for example, state that:

“... a fundamental issue in assessing earnings management is the unobservability of the managed [discretionary] and un-managed [nondiscretionary] components of reported earnings."

\footnotetext{
${ }^{1}$ Ronen and Yaari (2007) divide $\mathrm{RA}_{\mathrm{i}, \mathrm{t}}$ into two parts: the reversals accruals and the total accrual from the previous year.
} 
In the next section I review the main studies which have made significant contributions towards developing methodologies that estimate the discretionary and/or non-discretionary components of total accruals ${ }^{2}$.

\subsubsection{Healy (1985) Model}

Healy (1985) investigated whether firm managers manipulate earnings in order to increase the expected present value of their compensation packages. In order to do this, Healy (1985) had to develop a methodology which decomposed a firm's earnings into cash flows from operations, non-discretionary accruals and discretionary accruals. Here, Healy (1985) assumed that non-discretionary accruals are accounting adjustments to the firm's cash flows made in accordance with required accounting standards (e.g. GAAP, IFRS). Moreover, Healy (1985) argues that the nature of the double entry bookkeeping system is such that nondiscretionary accruals must, on average, be equal to zero. He uses this to argue that the expected discretionary accruals for the firm in any given year will be equal to the total accruals reported by the firm in that year. Healy (1985) then goes on to estimate total accruals as the difference between reported accounting earnings and the cash flow from operations. The cash flow from operations is estimated as the working capital from operations less changes in inventory and receivables, plus changes in payables and income taxes payable. Healy (1985) notes that this will mean discretionary accruals can be estimated through the following equation:

$$
D A C C_{t} \approx T A C C_{t}=-D E P_{t}-E X T_{t} * D_{1}+\left(\Delta A R_{t}+\Delta I N V_{t}-\Delta A P_{t}\right)-\left(\Delta T P_{t}+D_{1}\right) * D_{2}
$$

where:

2 A critique of the discretionary accruals models summarised in this section will be provided in Chapter 7 of this thesis. 
$\mathrm{DACC}_{\mathrm{t}}=$ Discretionary accruals in year $\mathrm{t}$;

$\mathrm{TACC}_{\mathrm{t}}=$ Total accruals in year $\mathrm{t}$;

$\mathrm{DEP}_{\mathrm{t}}=$ Depreciation in year $\mathrm{t}$;

$\mathrm{EXT}_{\mathrm{t}}=$ Extraordinary items in year $\mathrm{t}$;

$\mathrm{D}_{1} \quad=1$ if bonus plan earnings are defined after extraordinary items and 0 otherwise;

$\Delta \mathrm{AR}_{\mathrm{t}}=$ Accounts receivable in year $\mathrm{t}$ less accounts receivable in year $\mathrm{t}-1$;

$\Delta \mathrm{INV}_{\mathrm{t}}=$ Inventory in year $\mathrm{t}$ less inventory in year $\mathrm{t}-1$

$\Delta \mathrm{AP}_{\mathrm{t}}=$ Accounts payable in year $\mathrm{t}$ less accounts payable in year $\mathrm{t}-1 ;$

$\Delta \mathrm{TP}_{\mathrm{t}}=$ Income taxes payable in year $\mathrm{t}$ less income taxes payable in year $\mathrm{t}-1$;

$\mathrm{D}_{2}=1$ if bonus plan earnings are defined after income taxes and 0 otherwise.

Healy (1985) then employs this model to assess the impact of managerial bonus schemes on earnings management. He uses 1,527 firm-year observations collected from the 250 largest firms listed in the 1980 Fortune Directory and finds strong evidence that managers manipulate accruals in order to maximise the benefits they obtain under their compensation packages.

\subsubsection{DeAngelo (1986) Model}

DeAngelo (1986) questioned the validity of the Healy (1985) assumption that in expectations non-discretionary accruals will be equal to zero and that therefore, discretionary accruals will, on average, be equal to total accruals. DeAngelo (1986) first notes that the total accruals, AACC $_{t}$, for a firm will be equal to the sum of its discretionary accruals, $\mathrm{DACC}_{\mathrm{t}}$, and its non-discretionary accruals, $\mathrm{NDACC}_{\mathrm{t}}$, or: 


\section{$T A C C_{t}=D A C C_{t}+N D A C C_{t}$}

DeAngelo (1986) then argues that for most firms NDACC $_{t}$ will be both large and systematically negative because of the depreciation accrual. This in turn will mean that the assumption that discretionary accruals, $\mathrm{DACC}_{\mathrm{t}}$, are on average equal to total accruals, TACC $_{t}$, will lead to systematic biases in the Healy (1985) proxy for discretionary accruals. DeAngelo (1986) then suggests an alternative methodology which is based on the assumption that the normal total accruals in the current period are equal to the total accruals in the immediate prior period. DeAngelo (1986) then defines abnormal total accruals ( $\triangle \mathrm{TACC}$ ) as the difference between current total accruals and normal accruals, which, in turn, can be separated into discretionary and non-discretionary accruals, or:

$$
\Delta T_{A C C}=\left(\text { TACC }_{t}-\text { TACC }_{t-1}\right)=\left(D A C C_{t}-D A C C_{t-1}\right)+\left(N D A C C_{t}-N D A C C_{t-1}\right)
$$

In particular, DeAngelo (1986) assumes that the average change in nondiscretionary accruals $\left(\mathrm{NDACC}_{\mathrm{t}}-\mathrm{NDACC}_{\mathrm{t}}\right)$ is close to zero, so that the average change in total accruals $\left(\mathrm{TACC}_{\mathrm{t}+1}-\mathrm{TACC}_{\mathrm{t}}\right)$ largely reflects the change in discretionary accruals $\left(\mathrm{DACC}_{\mathrm{t}+1}-\mathrm{DACC}_{\mathrm{t}}\right.$ ). DeAngelo (1986) uses this model in conjunction with data for 64 U.S. management buyout proposals covering the period from 1973 until 1982 and finds no indication that managers of the sampled firms manipulate earnings in the period immediately before the management buyout occurs.

\subsubsection{Jones (1991) Model}

Jones (1991) proposes an expectation model that relaxes the DeAngelo (1986) assumption that there is very little change in a firm's non-discretionary accruals from one period until the next. In particular, Jones (1991) develops a model, under 
which a firm's total accruals evolve in terms of changes in its revenues and property, plant and equipment, or:

$$
T A C C_{i t}=a_{1 i}+a_{2 i} D R E V_{i t}+a_{3 i} P P E_{i t}+h_{i t}
$$

where:

$\mathrm{TACC}_{\mathrm{i}, \mathrm{t}}=$ Total accruals in year $\mathrm{t}$ for firm $\mathrm{i}$;

$\Delta R E V_{i, t}=$ Revenues in year $\mathrm{t}$ less revenues in year $\mathrm{t}-1$ for firm $\mathrm{i}$;

$\mathrm{PPE}_{\mathrm{i}, \mathrm{t}}=$ Gross property, plant and equipment in year $\mathrm{t}$ for firm $\mathrm{i}$;

$\varepsilon_{\mathrm{i}, \mathrm{t}} \quad=$ Stochastic error term in year $\mathrm{t}$ for firm $\mathrm{i}$.

However, Jones (1991, p. 212) notes that since firms become bigger over time, it is likely that the above model will suffer from problems of heteroscedacity. Hence, Jones (1991, p. 212) seeks to address this problem by deflating all variables by the previous period's total assets, in which case the regression is run in the following form:

$$
\frac{T A C C_{i, t}}{T A_{i, t-1}}=\propto_{1, i}\left(\frac{1}{T A_{i, t-1}}\right)+\propto_{2, i}\left(\frac{\Delta R E V_{i, t}}{T A_{i, t-1}}\right)+\propto_{3, i}\left(\frac{P P E_{i, t}}{T A_{i, t-1}}\right)+\varepsilon_{i, t}
$$

where:

$\mathrm{TA}_{\mathrm{i}, \mathrm{t}-\mathrm{l}}=$ Total assets at the end of year $\mathrm{t}-1$ for firm $\mathrm{i}$;

$\varepsilon_{\mathrm{i}, \mathrm{t}} \quad=$ Stochastic error term in year $\mathrm{t}$ for firm $\mathrm{i}$.

Total accruals in this model are calculated using the following procedure:

TACC $_{i, t}=\left[\Delta\right.$ Current Assets $_{i, t}-\Delta$ Cash $\left._{i, t}\right]-\left[\Delta\right.$ Current Liabilities $_{i, t}-$ $\Delta$ Short Term Debt ${ }_{i, t}$ - $\Delta$ Income Taxes Payable $\left._{i, t}\right]$ - Depreciation and Amortization Expense ${ }_{i, t}$ 
Jones (1991) argues that gross property, plant and equipment should be included in the expectation model instead of the depreciation expense in order to control for the portion of total accruals that is related to non-discretionary depreciation expenses. Jones (1991, p. 210) also notes that it has been argued in the literature that nondiscretionary accruals are a function of a firm's revenues (Kaplan 1985) and given this, the change in revenues earned by the firm are added as a control variable in his regression model.

Jones (1991) uses ordinary least squares to obtain estimates $\widehat{\boldsymbol{\alpha}_{1, \boldsymbol{l}}}, \widehat{\boldsymbol{\alpha}_{2, \boldsymbol{l}}, \widehat{\boldsymbol{\alpha}_{3, \boldsymbol{l}}}}$ of the parameters $\alpha_{1, i}, \alpha_{2, i}$ and $\alpha_{3, i}$, respectively. Jones (1991) then defines the discretionary accruals of firm $\mathrm{i}$ in year $\mathrm{t}$ as the error term from her regression model as follows:

$$
\frac{\mathrm{DACC}_{i, t}}{T A_{i, t-1}}=\left[\frac{T A C C_{i, t}}{T A_{i, t-1}}-\widehat{1_{1, \iota}}\left(\frac{1}{T A_{i, t-1}}\right)+\widehat{\propto_{2, \imath}}\left(\frac{\Delta R E V_{i, t}}{T A_{i, t-1}}\right)+\widehat{\varkappa_{3, \imath}}\left(\frac{P P E_{i, t}}{T A_{i, t-1}}\right)\right]
$$

where $\frac{\text { DACC }_{i, t}}{T_{A}, t-1}$ is discretionary accruals as a proportion of total assets for firm $i$ in year $\mathrm{t}$.

\subsubsection{Modified Jones (1991) Model (Dechow et al. (1995))}

Dechow et al. (1995) note that the revenues reported by a firm may be understated by managers' attempts to decrease reported earnings. This in turn may bias the estimate of discretionary accruals obtained under the Jones (1991) model. Dechow et al. (1995) seek to address this weakness by adjusting revenues in the original Jones (1991) model for the change in receivables that have occurred in the event period. Given this, Dechow et al. (1995) formulate the following modified Jones (1991) model for determining the total accruals for firm $i$ in year $t$ : 


$$
\frac{T A C C_{i, t}}{T A_{i, t-1}}=\propto_{1, i}\left(\frac{1}{T A_{i, t-1}}\right)+\propto_{2, i}\left(\frac{\Delta R E V_{i, t}-\Delta R E C_{i, t}}{T A_{i, t-1}}\right)+\propto_{3, i}\left(\frac{P P E_{i, t}}{T A_{i, t-1}}\right)+\varepsilon_{i, t}
$$

where:

$\mathrm{TACC}_{\mathrm{i}, \mathrm{t}}=$ Total accruals in year $\mathrm{t}$ for firm $\mathrm{i}$;

$\mathrm{TA}_{\mathrm{i}, \mathrm{t}-1}=$ Total assets at the end of year $\mathrm{t}-1$ for firm $\mathrm{i}$;

$\Delta \mathrm{REV}_{\mathrm{i}, \mathrm{t}}=$ Revenues in year $\mathrm{t}$ less revenues in year $\mathrm{t}-1$ for firm $\mathrm{i}$;

$\Delta \mathrm{REC}_{\mathrm{i}, \mathrm{t}}=$ Net receivables in year $\mathrm{t}$ less net receivables in year $\mathrm{t}-1$ for firm $\mathrm{i}$;

$\mathrm{PPE}_{\mathrm{t}}=$ Gross property, plant and equipment in year $\mathrm{t}$ for firm $\mathrm{i}$;

$\varepsilon_{\mathrm{i}, \mathrm{t}} \quad=$ Stochastic error term in year $\mathrm{t}$ for firm $\mathrm{i}$.

Similar to the original Jones (1991) model, the discretionary accruals for firm $i$ in year $t$ are estimated as the error term of the model.

\subsubsection{Dechow and Dichev (2002) Model}

Dechow and Dichev (2002) focus on working capital accruals. They start with the observation that a firm's earnings can be decomposed into its cash flow plus its accruals:

\section{Earnings $=$ Cash Flow + Accruals}

Dechow and Dichev (2002) then note that the realization of cash flows relating to working capital generally occur within one year and so, the cash flow can be divided into three principal groups:

$$
C F_{t}=C F_{t}^{t-1}+C F_{t}^{t}+C F_{t}^{t+1}
$$

where:

$$
\mathrm{CF}_{\mathrm{t}}=\text { Total cash flow year } \mathrm{t} \text {. }
$$


$\mathrm{CF}_{\mathrm{t}}^{\mathrm{t}-1}=$ Cash collections or payments of amounts relating to accruals in year $\mathrm{t}-1$.

$\mathrm{CF}_{\mathrm{t}}{ }^{\mathrm{t}}=$ Cash flows received or paid in the same period as the cash flows are recognized in earnings.

$\mathrm{CF}_{\mathrm{t}}^{\mathrm{t}+1}=$ Cash flows relating to accruals deferred until year $\mathrm{t}+1$.

Based on the assumption that all accruals will be realised in the next year, Dechow and Dichev (2002) argue that there are four kinds of accrual timing differences as summarized in Table 2.3.

Table 2.3: Summary of the Relationship between Accruals and Cash flow in Dechow and Dichev (2002)

\begin{tabular}{|c|c|c|}
\hline No & Accruals transactions & $\begin{array}{c}\text { The relationship between Accruals } \\
\text { and Cash flow }\end{array}$ \\
\hline 1 & $\begin{array}{l}\text { Recognising earnings in year } \mathrm{t} \\
\text { and cash flow in year } \mathrm{t}+1 \text { : } \\
\text { Opening accrual has the same } \\
\text { sign as the related cash flow. }\end{array}$ & $\mathrm{ACC}_{\mathrm{CFt}+1 / \mathrm{t}}=\mathrm{CF}_{\mathrm{t}+1}^{\mathrm{t}}+\varepsilon_{\mathrm{t}+1}^{\mathrm{t}}$ \\
\hline 2 & $\begin{array}{l}\text { Recognising earnings in year t-1 } \\
\text { and cash flow in year t: Closing } \\
\text { accrual has the opposite sign as } \\
\text { the related cash flow. }\end{array}$ & $\mathrm{ACC}_{\mathrm{CF} t \mathrm{t}-1}=-\mathrm{CF}_{\mathrm{t}}^{\mathrm{t}-1}-\varepsilon_{\mathrm{t}}^{\mathrm{t}-1}$ \\
\hline 3 & $\begin{array}{l}\text { Recognising earnings in year } \mathrm{t}+1 \\
\text { and cash flow in year } \mathrm{t} \text { : Opening } \\
\text { accrual has the opposite sign as } \\
\text { the related cash flow. }\end{array}$ & $\mathrm{ACC}_{\mathrm{CFt} / \mathrm{t}-1}=-\mathrm{CF}_{\mathrm{t}}^{\mathrm{t}+1}$ \\
\hline 4 & $\begin{array}{l}\text { Recognising earnings in year } \mathrm{t} \\
\text { and cash flow in year } \mathrm{t}-1 \text { : } \\
\text { Closing accrual has the same } \\
\text { sign as the related cash flow. }\end{array}$ & $\mathrm{ACC}_{\mathrm{CFt} t \mathrm{t}-1}=\mathrm{CF}_{\mathrm{t}-1}^{\mathrm{t}}$ \\
\hline
\end{tabular}

where: 
$\mathrm{ACC}_{\mathrm{CFa} / \mathrm{b}}=$ Accrual for which earnings is recognised in year a and cash flow is recognised in year $b$, and

$\mathrm{CF}_{\mathrm{m}}^{\mathrm{n}} \quad=$ Cash flow that is recognised in year $\mathrm{n}$ and earnings is recognised in year $\mathrm{m}$.

The errors term $\varepsilon_{t+1}{ }^{t}$ and $\varepsilon_{t}{ }^{t-1}$ reflect the difference between the accruals estimation and the cash flow realisation in the next year.

Dechow and Dichev (2002, p. 39) use the above analysis to argue that a firm's earnings may be decomposed into the following components:

Earnings $_{t}=$ Cash Flow $_{t}+$ Accruals $_{t}=$ CF $_{t}+$ Accruals $_{t}$

$$
\begin{aligned}
& \text { Earnings }_{t}=C F_{t}^{t-1}+C F_{t}^{t}+C F_{t}^{t+1}+\left[\left(C_{t+1}^{t}+\varepsilon_{t+1}^{t}\right)+\left(-C F_{t}^{t-1}-\varepsilon_{t}^{t-1}\right)+\left(-C F_{t}^{t+1}\right)\right. \\
& \left.+C F_{t-1}^{t}\right] \\
& \text { Earnings }_{t}=C \boldsymbol{F}_{t-1}{ }^{t}+\mathrm{CF}_{t}^{t}+C \boldsymbol{F}_{t+1}^{t}+\varepsilon_{t+1}{ }^{t}-\varepsilon_{t}^{t-1} \\
& A C C_{t}=\text { Accruals }_{t}=\text { Earnings }-C F_{t}=\left[C F_{t-1}{ }^{t}+C F_{t}^{t}+C F_{t+1}{ }^{t}+\varepsilon_{t+1}{ }^{t}-\varepsilon_{t}^{t-1}\right]-C F_{t} \\
& A C C_{t}=\left[C F_{t-1}^{t}+C F_{t}^{t}+C F_{t+1}^{t}+\varepsilon_{t+1}^{t}-\varepsilon_{t}^{t-1}\right]-\left[C F_{t}^{t-1}+C F_{t}^{t}+C F_{t}^{t+1}\right] \\
& A C C_{t}=C F_{t-1}^{t}-\left(C F_{t}^{t+1}+C F_{t}^{t-1}\right)+C F_{t+1}^{t}+\varepsilon_{t+1}^{t}-\varepsilon_{t}^{t-1}
\end{aligned}
$$

Dechow and Dichev (2002) interpret this formula to mean that: (i) accruals include all temporary adjustments that postpone or estimate the recognition of realized cash flows plus an error term; (ii) accruals are negatively associated with the current cash flow and positively associated with past and future cash flows, and (iii) the error term reflects how accruals fit into cash flow realizations and can be used as a measure of accruals and earnings quality. Dechow and Dichev (2002) then propose a "practical measure" of working capital accrual quality based on the following firm-level time-series regression model: 


$$
\Delta W C_{t}=\alpha+\beta_{1} C F O_{t-1}+\beta_{2} C F O_{t}+\beta_{3} C F O_{t+1}+\varepsilon_{t}
$$

where:

$$
\begin{aligned}
& \Delta \mathrm{WC}_{\mathrm{t}}=\text { Change in working capital in year } \mathrm{t} \text { (proxy for accruals); } \\
& \mathrm{CFO}_{\mathrm{t}}=\text { Cash flow from operations in year } \mathrm{t} ; \\
& \varepsilon_{\mathrm{t}} \quad=\text { Stochastic error term. }
\end{aligned}
$$

$\Delta \mathrm{WC}$ is computed as:

$$
\Delta W C=\triangle R E C+\triangle I N V E-\triangle P A Y A-\triangle T P A Y+\Delta O \text { ther Assets (net) }
$$

where REC is accounts receivable, INVE is inventory, PAYA is accounts payable and TPAY is taxes payable.

Dechow and Dichev (2002) argue that the residual $\left(\varepsilon_{\mathrm{t}}\right)$ from the above regression model captures the accruals that are not associated with cash flow realizations, and therefore the standard deviation of the residual in the above regression model $\left[\sigma\left(\varepsilon_{t}\right)\right]$ (at a firm-specific level) reflects the quality of the firm's accruals. Here it is important to note that Dechow and Dichev (2002) do not attempt to separate discretionary accruals from total accruals. Their intent is to assess the quality of a firm's accruals as a whole (McNichols 2002). However, Wysocki (2009) and Dechow et al. (2012) suggest that the Dechow and Dichev (2002) time series regression formula can be viewed as a model of non-discretionary accruals driven by cash flow transactions. Therefore the error terms $\left(\varepsilon_{t}\right)$ will reflect the level of discretionary accruals.

Dechow et al. (2012) also identify two weaknesses in the Dechow and Dichev (2002) model. First, the model uses a purely positive measure of accruals quality - that is, the standard deviation of the residual term in their regression model $\left[\sigma\left(\varepsilon_{t}\right)\right]$. The unsigned nature of this quality measure can reduce the power of tests when the 
researcher predicts accounting distortions in a particular direction. Second, the Dechow and Dichev (2002) model cannot capture the effect of long-term accruals on earnings manipulation due to the fact that cash flows are lagged for only one period in their time series regression model and therefore, the relationship between longterm accruals and cash flows cannot be captured by their modelling procedures.

\subsubsection{The Forward-looking Model (Dechow et al. (2003))}

The forward-looking model of discretionary accruals of Dechow et al. (2003) makes three important amendments to the modified Jones (1991) model; namely: (i) the separation of non-discretionary accruals from discretionary accruals in credit sales; (ii) controlling for lagged accruals, and (iii) controlling for growth in the sales revenue received by the firm (Ronen and Yaari 2007).

Dechow et al. (2003) begin their analysis of the modified Jones (1991) model by arguing that some credit sales may create non-discretionary accruals in the event period. They then suggest that the expected change in accounts receivable in any given period can be estimated from the change in sales over that period by invoking the following regression procedure:

$$
\Delta R E C=\alpha+k \Delta R E V+\varepsilon
$$

where:

$\triangle \mathrm{REC}=$ Change in accounts receivable;

$\Delta \mathrm{REV}=$ Change in revenues;

$\mathrm{k}=$ the sensitivity of the change in non-discretionary accounts receivable to sales;

$\varepsilon: \quad=$ Stochastic error term. 
The slope coefficient $\hat{k}$ which is estimated through the above regression will capture the expected change in accounts receivable for a given change in sales. Dechow et al. (2003) then argue that only the unexpected portion of the change in accounts receivable should be included as a component of discretionary accruals. Given this they subtract the full amount of the change in sales and add back the expected change in sales (which is $\hat{k}$ multiplied by the change in sales) and include it as an independent variable in their adaptation of the modified Jones (1991) model.

Second, Dechow et al. (2003) note that Beneish (1997), Chambers (1999) and Nwaeze (2001) amongst others provide evidence that the ability of an accruals model to predict discretionary accruals can be improved by incorporating lagged total accruals as an independent variable. Given this, Dechow et al. (2003) argue that the modified Jones (1991) model should be augmented by the inclusion of lagged total accruals as an independent variable.

Finally, Dechow et al. (2003) note how a firm that is growing and anticipates an increase in future sales will rationally increase its current investment in inventory. Thus, observing an increase in inventory is not necessarily due to managers manipulating earnings by not writing-off obsolete stock. However, the modified Jones (1991) model classifies such increases as earnings management. Given this, Dechow et al. (2003) argue that the modified Jones (1991) should be augmented to control for measures like this by including the proportionate change in sales as proxy for future sales growth.

Taking account of all these factors means that Dechow et al. (2003) estimate the total accruals for firm $\mathrm{i}$ in year $\mathrm{t}$ by employing the following cross-sectional forward-looking modified Jones (1991) regression model: 


$$
\begin{gathered}
\frac{\operatorname{TACC}_{i, t}}{A T A_{i, t}}=\propto_{1, i}\left(\frac{1}{A T A_{i, t}}\right)+\propto_{2, i}\left(\frac{(1+\hat{\mathbf{k}}) \Delta R E V_{i, t}-\Delta R E C_{i, t}}{A T A_{i, t}}\right)+\propto_{3, i}\left(\frac{P P E_{i, t}}{A T A_{i, t}}\right) \\
+\propto_{4, i} \frac{T A C C_{i, t-1}}{A T A_{i, t-1}}+\propto_{5, i} \frac{\Delta R E V_{i, t}}{R E V_{i, t}}+\varepsilon_{i, t}
\end{gathered}
$$

where:

$\mathrm{TACC}_{\mathrm{i}, \mathrm{t}}=$ Total accruals in year $\mathrm{t}$ for firm $\mathrm{i}$;

$\mathrm{ATA}_{\mathrm{i}, \mathrm{t}-1}:=$ Average total assets for firm i year $\mathrm{t}-1$;

$\Delta \mathrm{REV}_{\mathrm{i}, \mathrm{t}}=$ Revenue in year $\mathrm{t}$ less revenue in year $\mathrm{t}-1$ for firm $\mathrm{i}$;

$\Delta \mathrm{REC}_{\mathrm{i}, \mathrm{t}}=$ Net receivables in year $\mathrm{t}$ less net receivables in year $\mathrm{t}-1$ for firm $\mathrm{i}$;

$\mathrm{PPE}_{\mathrm{i}, \mathrm{t}}=$ Gross property, plant and equipment in year $\mathrm{t}$ for firm $\mathrm{i}$;

$\mathrm{REV}_{\mathrm{i}, \mathrm{t}}=$ Revenue in year $\mathrm{t}$ for firm $\mathrm{i}$;

$\varepsilon_{\mathrm{i}, \mathrm{t}} \quad=$ Stochastic error term in year $\mathrm{t}$ for firm $\mathrm{i}$.

Similar to the original Jones (1991) model, the discretionary accruals for firm $i$ in year $\mathrm{t}$ are estimated as the error term of the above model.

\subsubsection{McNichols (2002) Model}

In a commentary paper, McNichols (2002) argues that a combination of the original Jones (1991) model and the Dechow and Dichev (2002) model will lead to a more robust measure of earnings and accruals quality. In particular, McNichols (2002) proposes that the gross book value of a firm's property, plant and equipment and the change in its revenue should be included as independent variables in an augmented Dechow and Dichev (2002) time series regression model. The model would then take the following form:

$$
\Delta W C_{t}=\alpha+\beta_{1} C F O_{t-1}+\beta_{2} C F O_{t}+\beta_{3} C F O_{t+1}+\beta_{4} \Delta R E V_{t}+\beta_{5} P P E_{t}+\varepsilon_{t}
$$


where:

$$
\begin{aligned}
& \Delta \mathrm{WC}_{\mathrm{t}}=\text { change in working capital in year } \mathrm{t} \text { (proxy for accruals); } \\
& \mathrm{CFO}_{\mathrm{t}} \quad=\text { cash flow from operations in year } \mathrm{t} ; \\
& \Delta \mathrm{REV}_{\mathrm{t}}=\text { Revenues in year } \mathrm{t} \text { less revenues in year } \mathrm{t}-1 ; \\
& \mathrm{PPE}_{\mathrm{t}} \quad=\text { Gross property, plant and equipment in year } \mathrm{t} ; \\
& \varepsilon_{\mathrm{t}}: \quad=\text { Stochastic error term. }
\end{aligned}
$$

McNichols (2002) then uses a U.S. sample of 15,015 firm-year observations covering the period from 1988 until 1998 to compare the Jones (1991), Dechow and Dichev (2002) and the augmented Dechow and Dichev (2002) models. McNichols (2002) finds that all parameter estimates in the augmented Dechow and Dichev (2002) model are significantly different from zero in a statistical sense. This in turn will mean that both the Jones (1991) model and the original Dechow and Dichev (2002) model are afflicted by an omitted variables problem and will therefore return biased estimates of a firm's discretionary accruals. Given this, McNichols (2002) suggests that the augmented Dechow and Dichev (2002) model ought to be used in future research that deals with the quality of earnings and discretionary accruals.

\subsubsection{Performance Matched Model (Kothari et al. (2005))}

Kothari et al. (2005) develop a matched performance model of earnings and discretionary accruals quality by including both the return on the firm's assets (ROA) and a constant in the original Jones (1991) and the modified Jones (1991) regression models. Kothari et al. (2005) argue that the inclusion of the ROA acts as a control for firm performance whilst the inclusion of a constant term addresses three significant limitations of the original Jones (1991) and the modified Jones (1991) models: 
(i) the original Jones (1991) model seeks to address heteroskedasticity issues by deflating all variables by total assets. However, dividing all variables by total assets means that the Jones (1991) regression model no longer possesses an intercept term. Kothari et al. (2005) then note that heteroskedasticity issues cannot be fully alleviated by using total assets as a deflation variable alone and so they include an intercept term in the Jones (1991) model in order to address this problem;

(ii) the inclusion of a constant term in the Jones (1991) regression model will reduce the impact of omitted variables on the parameter estimates, and

(iii) a constant included in Jones (1991) regression model also helps to improve the power of the testing procedures.

Given the above factors, Kothari et al. (2005) propose the following amended specification of the modified Jones (1991) model:

$$
\begin{aligned}
\frac{T A C C_{i, t}}{T A_{i, t-1}}= & \alpha_{0}+\propto_{1, i}\left(\frac{1}{T A_{i, t-1}}\right)+\propto_{2, i}\left(\frac{\Delta R E V_{i, t}-\Delta R E C_{i, t}}{T A_{i, t-1}}\right)+\propto_{3, i}\left(\frac{P P E_{i, t}}{T A_{i, t-1}}\right) \\
& +\propto_{3, i} \operatorname{ROA}+\varepsilon_{i, t}
\end{aligned}
$$

where:

$\mathrm{TACC}_{\mathrm{i}, \mathrm{t}}=$ Total accruals in year $\mathrm{t}$ for firm $\mathrm{i}$;

$\mathrm{TA}_{\mathrm{i}, \mathrm{t}-1}=$ Total assets at the end of year $\mathrm{t}-1$ for firm $\mathrm{i}$;

$\Delta \mathrm{REV}_{\mathrm{i}, \mathrm{t}}=$ Revenues in year $\mathrm{t}$ less revenues in year $\mathrm{t}-1$ for firm $\mathrm{i}$;

$\Delta \mathrm{REC}_{\mathrm{i}, \mathrm{t}}=$ Net receivables in year $\mathrm{t}$ less net receivables in year $\mathrm{t}-1$ for firm $\mathrm{i}$;

$\mathrm{PPE}_{\mathrm{it}}=$ Gross property, plant and equipment in year $\mathrm{t}$ for firm $\mathrm{i}$;

$\mathrm{ROA}=$ Return on assets in year $\mathrm{t}-1$, and ${ }^{3}$

$\varepsilon_{\mathrm{i}, \mathrm{t}} \quad=$ Stochastic error term in year $\mathrm{t}$ for firm $\mathrm{i}$.

\footnotetext{
${ }^{3}$ Kothari et al. (2005) also use ROA in year $t$ for their later tests.
} 
Second, Kothari et al. (2005) match two firms from the same industry with the closest level of ROA. They detect earnings management by comparing the accruals of the two matched firms. Kothari et al. (2005) define performance matched discretionary accruals as follows:

$$
\text { PM.DACC } i, t=D A C C_{i, t}-D \widetilde{A C C}_{\jmath, t}
$$

where:

PM.DACC $\mathrm{i}_{\mathrm{i}, \mathrm{t}}=$ Performance matched discretionary accruals for firm $\mathrm{i}$ in year $\mathrm{t}$;

$\mathrm{DACC}_{\mathrm{i}, \mathrm{t}}=$ Discretionary accruals for firm $\mathrm{i}$ in year $\mathrm{t}$ (that is calculated either by the original Jones (1991) model as specified in section 2.1.4.3 or the amended interpretation of the modified Jones (1991) model as specified in this section);

$\widetilde{\mathrm{DACC}}_{\mathrm{j}, \mathrm{t}}=$ Discretionary accruals for firm $\mathrm{j}$ in year $\mathrm{t}$ that is matched to firm i (that is, also calculated using the original Jones (1991) model as specified in section 2.1.4.3 or the amended interpretation of the modified Jones (1991) model as specified in this section)

Kothari et al. (2005) argue that this method will more effectively control for heteroskedasticity issues. They also argue that it mitigates against the possibility of a false conclusion of earnings management when in fact the firm has experienced a significant increase in its rate of profitability. 


\subsection{Audit Factors and Earnings Management}

\subsubsection{Big N Auditor and Earnings Management}

I begin this subsection by emphasising that an auditor's principal function is to reduce the information asymmetries that exist between the managers of a client firm and the stakeholders of the firm by ensuring that the client firm's financial statements provide a "true and fair" view of the firm's financial position. Here Bartov et al. (2000) suggest that high quality auditors will be less willing to endorse financial reports which incorporate questionable accounting practices; rather, they are more likely to report the errors and irregularities contained in financial statements by issuing a qualified (or conditional) audit opinion (Rusmin 2010; DeFond and Subramanyam 1998). There are, in particular, a large number of studies that have used the bigger audit firms (e.g. Big 4 in US and UK, Big 5 in Malaysia) as a proxy for higher audit quality - particularly in relation to the use of accounting accruals in the manipulation of earnings. DeAngelo (1981b) formulates the fundamental theory in this area by demonstrating analytically that larger audit firms have greater incentives to detect and then report any material misstatements which may appear in an audit client's financial statements. DeAngelo (1981b) argues that larger audit firms have a bigger reputational capital to protect and therefore, they have a greater incentive to guard against potential litigation risk. This in turn will mean that they will take a more conservative approach to financial reporting issues than will be the case with smaller audit firms. Furthermore, DeFond and Subramanyam (1998) hypothesise that larger audit firms will have a greater level of expertise and therefore, the resources necessary to provide a higher quality of audit for their clients. DeFond and Subramanyam (1998) test this hypothesis based on a U.S. sample of 10,379 Big 6 and 2,179 non-Big 6 firm years covering the period from 1989 until 1992. Their analysis shows that client firms of non-Big 6 auditors are more likely to report higher levels of discretionary accruals 
that increase income than the client firms of Big 6 auditors. In particular, DeFond and Subramanyam (1998) show that clients of non-Big Six auditors report discretionary accruals that are, on average, 1.5-2.1 per cent of total assets higher than the discretionary accruals reported by clients of Big Six auditors.

Similarly, Krishnan (2003) examines the relationship between audit quality and the pricing of discretionary accruals using U.S. data covering from 1989 until 1998. He reports that there is a greater level of significance between the stock returns and discretionary accruals of the client firms of Big 6 auditors when compared to the client firms of non-Big 6 auditors. Likewise, the discretionary accruals of clients of Big 6 auditors have a statistically more significant relationship with future profitability than the discretionary accruals of clients of non-Big 6 auditors. Krishnan (2003) then concludes that market participants are likely to attach a greater weight to the discretionary accruals of client firms of Big 6 auditors relative to the discretionary accruals of Non-Big six audited firms. Using a sample of Singaporean firms in 2003, Rusmin (2010) also finds a lower level of discretionary accruals amongst firms with a Big 4 auditor relative to firms with a Non-Big 4 auditor. Moreover, Francis and Wang (2008) use a large sample of firms from 42 countries covering the period 1994 until 2004 and report that there is a statistically significant association between the level of investor protection regulation, the use of Big 4 auditors and the level of earnings quality around the world.

\subsubsection{Audit firm's Office Location and Earnings Management}

Choi et al. (2010) and Francis and Yu (2009) argue that audit engagements are normally administered and implemented by a partner and audit team from a local audit office and not by the national headquarters of the affected audit firm. Given this, audit decisions relating to a particular client firm are more often than not made at a local audit office level rather than by the national audit firm headquarters. This, 
in turn, means that the quality of a particular audit engagement needs to be assessed at the local audit office level. In particular, Francis and Yu (2009) hypothesise that for Big 4 firms audit quality will be primarily determined by the local audit office through which the audit is actually conducted. If the office through which the audit is conducted is relatively large then Francis and $\mathrm{Yu}$ (2009) argue that the audit will be of a higher quality in comparison to a relatively small audit office because of the larger resources and greater expertise that are available in the larger audit offices of the Big 4 firms. Francis and Yu (2009) test this hypothesis by using a sample of 6,568 U.S. firm-year observations which are audited by 285 Big 4 offices covering the period from 2003 until 2005. Their empirical results show that client firms whose audits are conducted by relatively large Big 4 audit offices (as measured by the aggregate audit fees received by the particular Big 4 audit office) will have tendency to have smaller DACCs in comparison to client firms audited through relatively smaller Big 4 audit offices. Similarly, Choi et al. (2010) hypothesise that audit offices which have a larger number of audit clients will have more audit experience and less incentives to compromise their independence. Choi et al. (2010) use a sample of 3,482 pooled office-years for U.S. audit client firms covering the period from 2000 until 2005 and report results which show that audit office size (in term of the number of audit clients in each office) has a significant negative association with the level of DACCs for the client firms audited out of that office.

\subsubsection{Audit Busy Season and Earnings Management}

Current research indicates that the workload pressures which arise in the audit busy season will lead to potential degradation in auditor performance and therefore lower audit quality (Agoglia et al. 2010; Coram et al. 2004). In particular, Sweeney and Summers (2002) use U.S. survey evidence to show that audits conducted 
during the busy audit season are characterised by job burnout that leads to reduced auditor commitment. Jones III et al. (2010) summarize U.S. experimental results which indicate that an auditor's healthy lifestyle and stress levels are significantly associated with their job outcomes. Moreover, Johnson-Moreno (2003) argue that audits conducted during the busy audit season can lead to auditor stress that in turn may lead to mental, emotional and physical issues that can have an adverse effect on the human biochemical and immune systems. However, until now only a few published studies have examined the relationship between audits conducted during the audit busy season and the magnitude of discretionary accruals. López and Peters (2012), for example, use a sample of 8,384 U.S. firm-year observations covering the period from 2006 until 2009 and report evidence that abnormal accruals are generally higher when audits are conducted during the audit busy season.

\subsubsection{Auditor Change and Earnings Management}

Regulators view auditor changes with a great deal of suspicion because of the implication that they may be motivated by opportunistic behaviour arising out of a client firm's desire to appoint an auditor who will be willing to accept the accounting policies that will enable the client firm to achieve its financial reporting objectives (Francis and Wilson 1988; DeFond 1992). However, DeFond and Subramanyam (1998) provide an alternative explanation for auditor changes. They argue that auditors often prefer conservative accounting policies in order to protect themselves against future litigation and the potential damages which arise out of the discretionary accrual accounting policies invoked by client firms. However, the level of conservatism practised will vary between auditors due to the individual assessments of client risk and the relative risk propensities of each auditor. Hence, if a client firm's management believe that the incumbent auditor is more 
conservative than the "average" audit firm, then the client firm may have a motivation to remove its incumbent auditor in order to search for a less conservative successor audit firm. DeFond and Subramanyam (1998) also argue that due to the asymmetric effects of discretionary accrual accounting policies, client firms will prefer income increasing discretionary accruals rather than income decreasing discretionary accruals. Since income increasing discretionary accruals are more likely to lead to litigation risks than income decreasing discretionary accruals, DeFond and Subramanyam (1998) hypothesise that auditor changes are likely to be preceded by a year in which discretionary accounting accruals are income decreasing. DeFond and Subramanyam (1998) test this hypothesis using a sample of 503 U.S. firms that change auditors during the four year period from 1990 until 1993. DeFond and Subramanyam (1998) use the Jones (1991) model to estimate discretionary accruals. Their findings show that discretionary accruals are in general income decreasing in the year before the client firm changes its auditor. They also find that in general the discretionary accruals continue to be negative in the first year of the new auditor's term of office but that the magnitude of the discretionary accruals are much smaller than those in the previous year. DeFond and Subramanyam (1998) conclude from this that auditor changes are precipitated by the tensions which arise between client firms and their auditors over the level of discretionary accruals.

However, the subsequent study of Lee et al. (2003) has been unable to replicate the DeFond and Subramanyam (1998) findings. Lee et al. (2003) refine the methodology employed in the DeFond and Subramanyam (1998) study by employing a sample based on a longer time period - namely, from 1991 until 1997 - and using the modified Jones (1991) model (Dechow et al. 1995) to calculate discretionary accruals. Their empirical results are consistent with the hypothesis that client firms are not more likely to switch auditors if their discretionary accruals 
are negative in the previous year. Moreover, the Lee et al. (2003) empirical findings also show that client firms which switch auditors will in general have discretionary accruals that are closer to the industry norm for discretionary accruals in the subsequent period than client firms that do not change their auditors. This result is diametrically opposed to that obtained by DeFond and Subramanyam (1998) who document that there is a decrease in the magnitude of discretionary accruals in the first year of the new auditor's term of office.

\subsubsection{Audit Opinion and Earnings Management}

There are a limited number of studies which examine the association between qualified (or conditional) audit opinions and accounting accruals (Johl et al. 2007; Francis and Krishnan (1999)) and Bradshaw et al. (2002) test the hypothesis that auditors will protect themselves against the risk exposure arising from discretionary accruals by lowering the threshold they apply for the issuance of a qualified (or conditional) audit opinion. Both studies use a large sample of U.S. publicly listed firms and find that there is a significant positive relationship between the level of discretionary accruals and the probability of an audit firm issuing a qualified (or conditional) audit opinion. Furthermore, Francis and Krishnan (1999) also conclude that income-increasing discretionary accruals are more likely to lead to a qualified (or conditional) audit opinion than incomedecreasing discretionary accruals, although this latter result only holds when the auditor is a member of the Big 6 group of audit firms. Similarly, Johl et al. (2007) use Malaysian data covering the period from 1994 until 1999 and also conclude that Big 5 auditors in Malaysia appear to qualify their audit reports more frequently than their non-Big 5 counterparts when high levels of discretionary accruals are involved. 


\subsubsection{Non-audit Fees and Earnings Management}

The threat that non-audit services pose to auditor independence has long been recognized and debated by regulators throughout the western world. There is a considerable volume of anecdotal and empirical evidence that supports the proposition that when large fees are paid to an auditor, particularly those related to NAS, the auditor becomes more economically dependent on the client and this has the potential to compromise their audit independence (Simunic 1984). In particular, financial reliance may induce a relationship whereby the auditor becomes reluctant to make appropriate inquiries during the conduct of the audit or to change figures and/or information appearing in the audit client's financial statements for fear of losing highly profitable non-audit service fees. It was because of this perceived threat to auditor independence - and in particular, the crisis of investor confidence in the audit function that emerged as a result of the Enron crisis - that the U.S. Congress passed the Sarbanes-Oxley Act of 2002 (SOX). Under SOX auditors are banned from providing certain non-audit services to their audit clients (Knechel et al. 2012). However, the accounting profession resisted the SOX ban on the ground that the provision of non-audit services has the important secondary benefit of enabling the audit firm to obtain a greater understanding of the nature of the audit client's business and of its accounting system and procedures (Wallman 1996). Melancon (2000, p. 27), who at the time was President of the AICPA, argued that "there will be a loss of synergies" as a result of the SOX ban since "the loss of nonaudit service lines will reduce the scope of knowledge available [to audit] firms".

Here I should note that the empirical evidence on this matter is ambiguous and unclear at best (Larcker and Richardson 2004). Frankel et al. (2002) conduct empirical work based on U.S. data and conclude that auditors who are concerned about the possible loss of non-audit service fee income will be more likely to 
compromise their audit independence. Moreover, Jenkins and Krawczyk (2001) examined how six different types of non-audit services influenced the perceptions of U.S. CPA firm professionals with respect to auditor independence. Their empirical results indicate that there is a gap in understanding between the general public and the accounting profession regarding the impact that the provision of non-audit services has on auditor independence. Simunic (1984) developed an empirical model of the joint demand for audit and non-audit services, and showed that for his sample of U.S. audit firms the provision of management advisory services (MAS) is associated with a significant increase in the audit fees received by audit firms. However, Simunic (1984) interpreted his results as indicative of a "knowledge spillover" effect because the auditor obtains a greater understanding of the audit client's business and accounting systems as a result of the non-audit services it provides.

Further empirical evidence on this matter is provided by Mauldin (2003) who concluded that professional investors perceive that auditor independence is impaired when auditors provide non-audit services with a special focus on internal audit services and on merger and acquisition services. Frankel et al. (2002) used the ratio of non-audit service fee income to total audit fees as a measure of audit independence and found that it had a significant association with two measures of biased financial reporting; namely, the magnitude of a firm's discretionary accruals and the likelihood of a firm meeting a given set of earnings benchmarks (that proxy for auditor independence). The Frankel et al. (2002) results provide evidence that audit clients paid high non-audit services fees relative to total fees engage in biased financial reporting and thus, auditor independence is compromised when audit clients purchase a large proportion of non-audit services from their auditors. 
In contrast, Davis et al. (1993) refined the Simunic (1984) model by adding an audit effort variable to the Simunic (1984) regression equation in order to test whether non-audit services do in fact have a knowledge spillover effect. Davis et al. (1993) used audit data from one large public accounting firm and were unable to find a relationship between audit fees for a given level of audit effort and nonaudit fees. In précis, Davis et al. (1993) conclude that the provision of non-audit services for audit clients does not result in incentives for auditors to compromise their objectivity. The results of Ashbaugh et al. (2003) also indicate that there is no systematic evidence supporting the claim that auditors violate their independence as a result of clients purchasing relatively more NAS. This result is supported by evidence presented in Chung and Kallapur (2003) and Larcker and Richardson (2004) who also show that the provision of non-audit services does not appear to impair auditor independence. Using other dependent variables for biased financial reporting as evidence of auditor independence violations, other researchers also obtain the same result; namely, that the frequency of modified audit opinions (DeFond et al. 2002; Hay et al. 2006a) or the frequency of financial restatements (e. g., Raghunandan (2003)) have no association with the provision of non-audit services.

Kinney et al. (2004) examine the relationship between different kinds of non-audit services provision on the one hand and restatements of previously filed financial statements on the other. They do not find a significant association between fees for either financial information systems design and implementation or internal audit services on the one hand and earnings restatements on the other. The differing views on the relationship between audit quality and the incidence of auditor independence suggests that there is considerable potential for further research in this area. 


\subsection{The Influence of Earnings Management on the Level of Audit Fees}

DACCs are related to accounting items that require a significant level of audit judgment in which case high levels of DACCs will impact on the degree of audit risk. This in turn will lead to more audit effort and to an increased level of audit fees (Gul et al. 2003; Fatima 2011). As a result of this, Gul et al. (2003) and Fatima (2011) hypothesise that there is a positive relationship between the level of DACCs and the level of audit fees. Gul et al. (2003) employ a sample of 648 Australian firms covering the year 1993 and Fatima (2011) uses a U.S. sample of 8,187 firmyears covering the period from 2000 until 2006 to test this hypotheses. Both studies report a significant relationship between the level of DACCs and the level of audit fees. Moreover, both Gul et al. (2003) and Fatima (2011) also argue that where the management of a firm holds a significant proportion of the firm's equity stock then they are likely to use DACCs to communicate value relevant information to their shareholders. Similarly, managers of firms with high levels of accounting-based compensation are likely to use DACCs opportunistically to manipulate earnings in order to increase the levels of compensation they receive. That is, both Gul et al. (2003) and Fatima (2011) assume that the relationship between DACCs and audit fees are affected by managerial incentives emanating from the compensation packages they receive. Gul et al. (2003) measure these incentives by the level of managerial share ownership and the level of accounting-based management compensation while Fatima (2011) uses the chief financial officer's compensation structure as a proxy for overall managerial incentives. Gul et al. (2003) report evidence which shows that the positive relationship between DACCs and audit fees is negatively affected by managerial ownership; and that the impact of managerial ownership is weaker for firms which have high accounting-based management compensation packages. Similarly, Fatima (2011) finds that the relationship 
between DACCs and audit fees is significantly higher when the chief financial officer's bonuses increase and is moderated as the chief financial officer's salary increases relative to other compensation payments.

Abbott et al. (2006) also examine the relationship between DACCs and the level of audit fees but they hypothesise that audit fees are asymmetrically associated with income-increasing versus income-decreasing earnings management risk (as estimated by positive and negative DACCs, respectively). Abbott et al. (2006) note that the magnitude and direction of earnings management increases litigation risk for auditors asymmetrically (Palmrose and Scholz 2004; Heninger 2001). In particular, the litigation risk is higher for income-increasing earnings management and lower for income-decreasing earnings management. Abbott et al. (2006) then argue that due to the fundamental role which litigation risk plays in an auditor's fee-setting process, the audit fee that an auditor charges must also be asymmetrically associated with the magnitude and direction of the client firm's earnings management. They therefore hypothesise that the magnitude of the audit fee will decrease (increase) with the risks arising from the client firm's incomedecreasing (increasing) earnings management practices. Abbott et al. (2006) use a sample of 429 U.S. audit fee disclosures from proxy statements filed with the Securities and Exchange Commission in the year 2000. They employ the modified Jones (1991) model to estimate DACCs. The Abbott et al. (2006) empirical results show that income-decreasing earnings management risk, as estimated by negative DACCs, is significantly associated with lower audit fees. In contrast, incomeincreasing earnings management risk, as estimated by positive DACCs, is associated with higher audit fees. These results are different to those obtained by Gul et al. (2003) and Fatima (2011). Here, Gul et al. (2003) only find a significant relationship between audit fees and income-increasing DACCs but fail to find a 
significant association between audit fees and income-decreasing DACCs. Similarly, Fatima (2011) reports a significant relationship for both incomedecreasing DACCs and income-increasing DACCs but finds an insignificant relationship between audit fees and the interaction of income-decreasing DACCs and chief financial officers' compensation structures.

Unfortunately, the empirical research conducted in this area is afflicted by two methodological deficiencies. First, earnings management is an endogenous variable in the audit fee models summarised in the literature (Antle et al. 2006). On the one hand, the detection of earnings management will increase audit effort. If, however, an auditor increases their audit effort, it is likely that they will detect even more earnings management. This in turn will reduce the earnings management risk associated with the client firm's audited financial statements. Thus, in a regression of audit fees on discretionary accruals, the level of the discretionary accruals will be correlated with the error term in the regression equation and this will lead to biased estimates of parameter values. Second, professional accounting bodies generally require that at the beginning of the fiscal year an audit firm and its audit client will negotiate a provisional audit fee (based on the estimated time required for the audit and the rate to be paid per hour to audit operatives) and they will both sign an engagement letter to that effect. After this the audit firm will base the final audit fee on the actual audit work required and their standard charge-out rates (NZICA 2009; IFAC 2009; Hackenbrack et al. 2011). However, when Hackenbrack et al. (2011) interviewed audit partners from three of the Big 4 U.S. audit firms they found that most audit fees are generally fixed fee contracts under which audit fees for additional services must be approved by the client firm's audit committee either in advance or be negotiated on the basis of unusual transactions or events that require additional audit time and effort. 
Overall, recent research generally reports a significant relationship between audit fees and DACCs and finds that this relationship is driven by the incentives arising out of the managerial compensation schemes employed by firms. Furthermore, recent studies only find a positive and significant association between audit fees and income-increasing DACCs and report mixed results about the relationship between income-decreasing DACCs and audit fees.

\subsection{Conclusion}

Chapter 2 has reviewed the literature relevant to earnings management and its relationship with the audit factors identified in the thesis. The pre-existing literature indicates that not all earnings management is misleading and that it is often difficult to distinguish between earnings manipulation that ultimately proves to be fraudulent and the on-going actions of management to keep costs within budgets or to get revenues to meet desired sales targets. Moreover, empirical researchers have been unable to find a completely satisfactory methodology for distinguishing between discretionary accruals and non-discretionary accruals (Elgers et al. (2003). Thus, section 2.1 of chapter 2 has reviewed the main studies which have made significant contributions towards developing methodologies that estimate the discretionary and/or non-discretionary components of total accruals.

Section 2.2 then goes on to summarise recent research that investigates the impact of six important factors of auditor quality and auditor independence on the level of DACCs. These factors are: (1) whether the audit is conducted by a Big 4 audit firm; (2) the location of the audit office; (3) the provision of non-audit services; (4) whether the audit is conducted during the audit busy season; (5) whether the client firm changes auditor, and (6) whether the client firm receives a qualified or conditional audit opinion. Section 2.3 also summarises an emerging literature that relates the level of DACCs in the current year to the audit fees paid in subsequent 
years. The main conclusions from my cataloguing of the pre-existing literature are: (1) the empirical evidence which deals with the relationship between audit factors and the level of DACCs is generally conflicting and inconsistent; (2) there is only a very limited volume of research output that deals with the relationship between audit factors and the level of DACCs in a New Zealand context and (3) the current empirical evidence which deals with the relationship between DACCs and audit fees is afflicted by serious methodological deficiencies and potential biases. 


\section{CHAPTER 3 \\ RESEARCH SETTING IN NEW ZEALAND}

In chapter three, I summarise the current status of audit research in New Zealand. I commence my analysis in section 3.1 with a brief summary of the principal characteristics of the audit market in New Zealand. In section $3.2 \mathrm{I}$ move on to discuss the New Zealand audit legislative environment and of how it provides a unique setting for those who wish to conduct empirical research dealing with the relationship between audit factors and earnings management. Section 3.3 and 3.4 then go on to summarise New Zealand audit regulations relating to non-audit services; the procedures relating to the appointment and replacement of auditors; regulations relating to the proper conduct of audit fee negotiations; regulations relating to the issue and content of audit opinions; and New Zealand Stock Exchange. Section 3.5 concludes the chapter.

\subsection{New Zealand Audit Market}

\subsubsection{Overview of New Zealand Economy}

I would begin by noting that the New Zealand economy is relatively small in comparison to other advanced industrialised countries. According to the $\mathrm{New}$ Zealand Economic and Financial Overview 2013 Report, New Zealand comprises a land area of only 268,000 square kilometres (103,000 square miles). It is similar in size to Japan or Britain but significantly smaller than Australia and the United States. Moreover, New Zealand's resident population is much smaller than other advanced industrialised countries. The population of New Zealand at 30 June, 2012 is estimated at 4,433,000 compared to $63,181,775$ in United Kingdom (2011 UK census) and 127,360,000 in Japan (estimated at March 1, 2013). New Zealand's 
population is also highly urbanised with around $72 \%$ of the resident population living in urban areas. As reported in the New Zealand Economic and Financial Overview 2013 Report, in June 2010, over 53\% of New Zealanders live in the four main urban areas of Auckland $(1,354,900)$, Hamilton $(203,400)$, Wellington $(389,700)$ and Christchurch $(390,300)$. Furthermore, New Zealand's population is also mainly concentrated in the North Island (about 76\%) with the remaining population $(24 \%)$ in the South Island.

New Zealand has a relatively small but open economy that broadly operates on free market principles. In 2011, New Zealand's Gross Domestic Product (GDP) amounted to \$US 160 billion. This figure is much lower than that for Australia (\$US 1,379 billion), the U.K. (\$US 2,445 billion), Japan (\$US 5,867 billion) and the United States (\$US 14,991 billion) (World Bank 2011a). However, the New Zealand GDP per capita is relatively high at appropriately \$US 36,254 compared to an average of \$US 41,062 for the list of 71 high income countries prepared by the World Bank (World Bank 2011b).

Figure 3.1: Gross Domestic Product in 2011

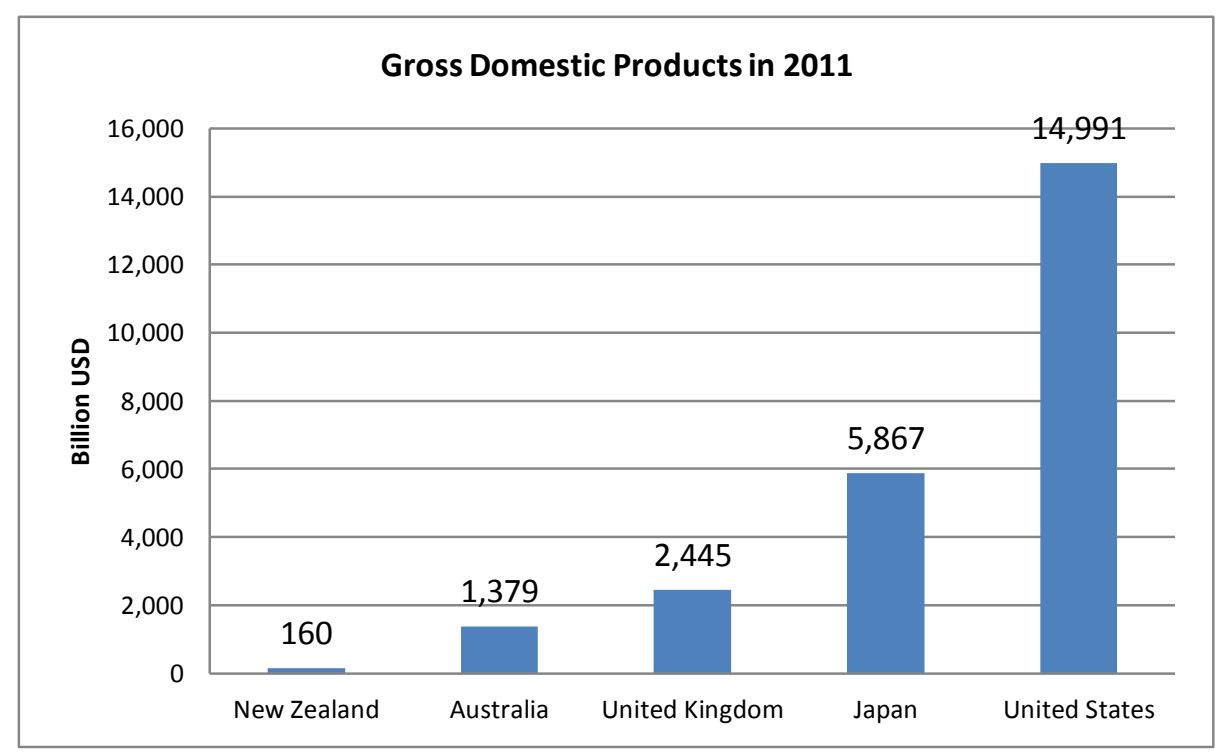

Source: World Bank Data 2011 
Figure 3.2: GDP per capita in 2011

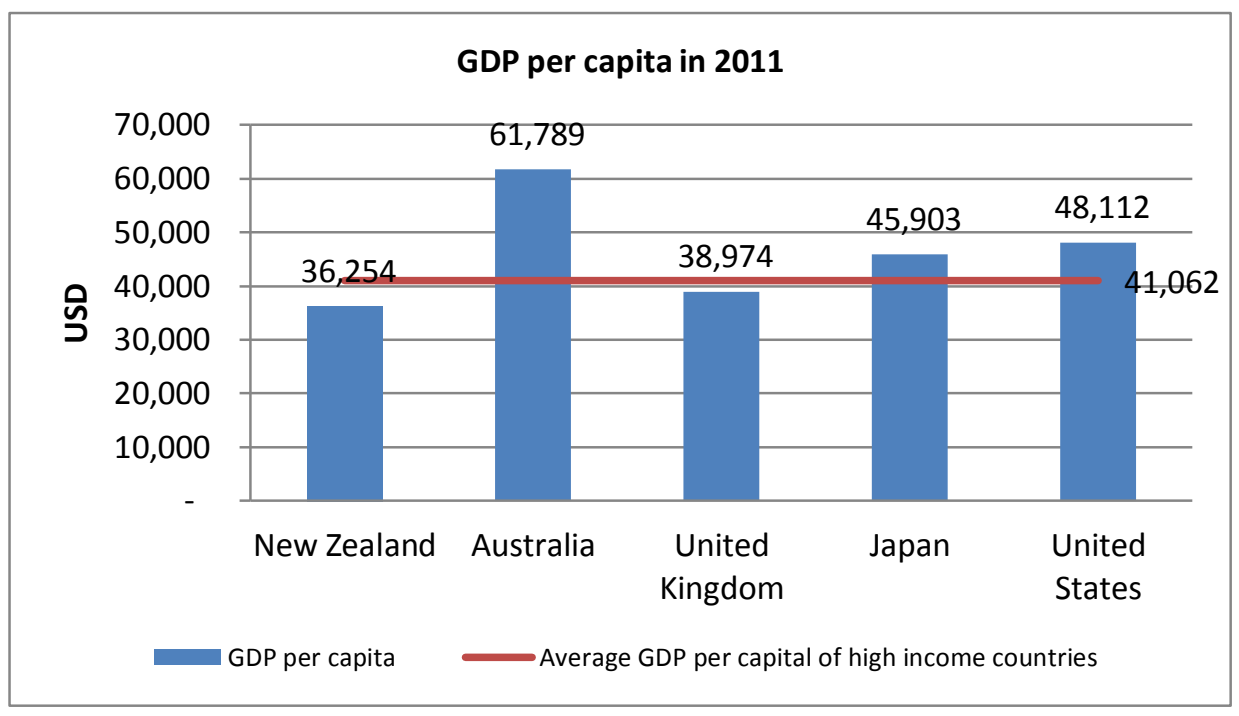

Source: World Bank Data 2011

\subsubsection{New Zealand Audit Market Characteristics}

Whilst the audit market in New Zealand shares many of the common features found in the audit markets of other advanced industrialised countries it also has some unique characteristics of its own. The New Zealand audit market whilst relatively small is also well developed and sophisticated. In particular, Hay and Jeter (2011) note that the New Zealand audit market is similar to that in other advanced industrialised countries in terms of legal requirements and professional standards and also, is dominated by the Big 4 auditing firms. Here Zhang and Emanuel (2008), Hay et al. (2006a) and Hay and Jeter (2011) amongst others report that around $88 \%$ of the firms comprising the samples on which their empirical analysis is based are audited by a Big 4 audit firm. In a more exhaustive study, Cahan et al. (2008) who use a database consisting of 814 New Zealand companies listed on the New Zealand Stock Exchange over the period from 1995 until 2001 report that over $90 \%$ of the firms comprising their sample are audited by a Big 4 
audit firm. Moreover, Hay and Jeter (2011) also report that New Zealand audit fees are compatible with those in other Western countries in the sense that their primary determinants appear to be client size and the risk and complexity associated with the particular audit client.

However, as previously emphasised, the New Zealand audit market also has some unique characteristics. First, as with the New Zealand economy in general, the audit market in New Zealand is concentrated in the two largest cities of Auckland and Wellington. For example, Knechel et al. (2012) use a sample of 115 companies listed on the New Zealand Stock Market (NZSX) in the fiscal years 2004 and 2005 and show that there are 77 firms with an auditor whose principal office is located in Auckland and 12 firms with an auditor whose principal office is located in Wellington. Second, the relatively small size of the New Zealand economy means that the New Zealand audit market is also relatively small. This potentially at least can create greater opportunities for a closer relationship between New Zealand auditors and their client firms. Here, Sharma et al. (2011) argue that the closer the relationship between an auditor and their client firms, the more likely it will be that the auditor will act in ways which allow their clients to manipulate the information appearing in their published financial statements. This argument is consistent with the fact that in recent years there have been a relatively small number of New Zealand companies which have received a modified or qualified audit opinion. Hay et al. (2006a), for example, note that that in 1999, there were only 6 of the 177 companies listed on the NZSX which received a modified or qualified audit opinion. In 2000, only 7 of the 224 companies listed on the NZSX received a modified or qualified audit opinion whilst in 2001, 15 of 243 companies received a modified or qualified audit opinion. These are rates which are considerably smaller than those which prevail in other advanced industrialised countries (Sharma et al. 2011). Finally, I would note that New Zealand has a low private litigation environment (Dunstan et al. 2011) and this provides additional incentives for auditors to be less meticulous about insuring both the quality of their audit 
procedures and their independence. The Securities Commission of New Zealand Report (NZSEC (2007) also notes that in most developed countries there are detailed legislative provisions that cover an auditor's liability in the event of negligence, fraud and/or other misdemeanours. However, it was not until 2011 that the New Zealand government enacted the New Zealand Auditor Regulation Act which put into place regulatory and administrative procedures relating to the New Zealand auditing profession which are similar to those which prevail in most other advanced industrialised countries.

\subsection{Auditing Legislation Environment in New Zealand}

The New Zealand environment provides a unique setting for those who wish to conduct empirical research dealing with the relationship between auditor independence, audit fees and earnings management. First, unlike the United States where the Public Company Accounting Oversight Board (PCAOB) is the government agency responsible for regulating the auditing profession and the United Kingdom where the Financial Reporting Council (FRC) is the body that regulates the auditing profession, in New Zealand there has until recently been no government agency which regulates the auditing profession. The regulation of the auditing profession in New Zealand has instead largely been conducted under the auspices of the New Zealand Institute of Chartered Accountants (NZICA) which is a privately funded professional accounting body (Knechel et al. 2012; Sharma et al. 2011). The NZICA was established by Royal Charter under the New Zealand Institute of Chartered Accountants Act (1996) as "a body corporate with perpetual succession and a common seal, and has and may exercise all the rights, powers, and privileges, and may incur all the liabilities and obligations, of a natural person of full age and capacity". The NZICA has exercised the powers and privileges granted under its Royal Charter to oversee the quality, expertise, and integrity of its 
members in relation to auditing standards in New Zealand. However, since the NZICA is a is a privately funded professional body it has led to a perception amongst the New Zealand public, the business community, investors and others that self-regulation of the auditing profession through the NZICA has been less rigorous than in other advanced industrialised countries where the regulation of the auditing profession is conducted by an independent government funded body. In 2007, the views of the New Zealand public, the business community, investors and others on this matter was captured in a report issued by the Securities Commission of New Zealand (NZSEC 2007). The report stated that:

“... New Zealand currently lacks an independent audit oversight structure and has fallen behind other jurisdictions in this regard."

The New Zealand government has responded to this perceived lack of rigour in the regulation of the auditing profession by passing into law the New Zealand Auditor Regulation Act, 2011. Under the New Zealand Auditor Regulation Act, the Financial Markets Authority (FMA) has ultimate responsibility for establishing and maintaining an independent oversight system in order to promote the quality and integrity of auditing practices in New Zealand. The responsibilities of the FMA are to issue licences which permit individuals and firms to practice as auditors, to monitor the quality of and regulate auditing practices in New Zealand and to conduct audit quality reviews. Moreover, the responsibility for issuing auditing standards has also been transferred from the NZICA to the External Reporting Board (XRB) which is an independent government body established by the New Zealand Ministry of Business, Innovation and Employment, under section 22 of the Financial Reporting Act 1993, and subject to the Crown Entities Act 2004. The powers and responsibilities of the various government agencies for the regulation 
of auditing standards and practices in New Zealand after July, 2011 are summarised in Table 3.1.

Table 3.1: Audit Profession Oversight Functions changes under the

New Zealand Auditor Regulation Act, 2011

\begin{tabular}{|l|c|c|}
\hline \multicolumn{1}{|c|}{ Audit Profession Oversight Functions } & $\begin{array}{c}\text { Before } \\
\text { July 2011 }\end{array}$ & $\begin{array}{c}\text { After July } \\
2011\end{array}$ \\
\hline $\begin{array}{l}\text { Promote quality, expertise, and integrity in the profession of } \\
\text { accountancy by its members in New Zealand }\end{array}$ & NZICA & FMA \\
\hline $\begin{array}{l}\text { Promote, control, and regulate the profession of accountancy } \\
\text { by its members in New Zealand }\end{array}$ & NZICA & XRB \\
\hline $\begin{array}{l}\text { Promote the training, education, and examination of persons } \\
\text { practising, or intending to practise, the profession of } \\
\text { accountancy in New Zealand }\end{array}$ & NZICA & NZICA \\
\hline
\end{tabular}

\subsection{Audit Regulations in New Zealand}

As noted in section 3.1, before July 2011 the NZICA had primary responsibility for the regulation and supervision of auditing standards in New Zealand. In order to exercise this duty, in 2002 the NZICA issued its Code of Ethics (as subsequently amended in 2003 and 2006) which was designed to assist NZICA members to comply with the highest of ethical standards and to meet their responsibilities to act in the public interest. Here, paragraph 15 of the Code of Ethics defines "the public interest as the collective well-being of the community of people and institutions the profession serves such as clients, governments, employers, employees, investors, creditors, the business and financial community, and others who rely on the objectivity and integrity of members for sound financial accounting and reporting, effective financial management and competent advice on a variety of business and taxation matters." The Code of Ethics provides five Fundamental Principles that form the basis of the behaviour expected from NZICA members. Each 
Fundamental Principle is, in turn, supported by a number of specific Rules that "flesh out" aspects of sound professional and ethical behaviour including examples of appropriate ethical behaviour in typical situations that auditors are likely to encounter. However, the Code Rules and Applications are not expected to cover all circumstances and NZICA members must then have resort to the five Fundamental Principles in order to determine the appropriate ethical behaviour in such nonstandard situations. A summary of the Fundamental Principles and their associated Rules are presented in Table 3.2. 
Table 3.2: Summary of Code of Ethics issued by NZICA in 2002 as amended in 2003 and 2006

\begin{tabular}{|c|c|c|}
\hline No & Fundamental Principle & Rules \\
\hline 1 & $\begin{array}{l}\text { The Fundamental } \\
\text { Principle of Integrity }\end{array}$ & $\begin{array}{l}\text { - Rule } 1 \text { "Incompatible Activities": A member must not engage in any business, occupation or activity which } \\
\text { impairs or might impair the member's integrity, or the good reputation of the profession. } \\
\text { - Rule } 2 \text { "False or Misleading Statements": A member must not make, prepare or certify, or permit or direct } \\
\text { another person to make, prepare or certify, any statement which the member knows, believes or ought to know } \\
\text { to be false, incorrect or misleading, or open to misconstruction, by reason of the misstatement, omission or } \\
\text { suppression of a material fact or otherwise. }\end{array}$ \\
\hline 2 & $\begin{array}{c}\text { The Fundamental } \\
\text { Principle of Objectivity } \\
\text { and Independence }\end{array}$ & $\begin{array}{l}\text { - Rule } 3 \text { "Objectivity": Members must perform all professional work with an objective mind. } \\
\text { - Rule } 4 \text { "Independence": Members performing certain types of assurance engagements, such as the external } \\
\text { audit or review of a financial report, must be independent of the entity and the subject matter on which they are } \\
\text { reporting. Independence is also important for some other professional services, including some insolvency } \\
\text { engagements, independent business valuations, appraisal reports under the NZSX Listing Rules, and expert } \\
\text { witness engagements. } \\
\text { Rule } 5 \text { "Disclosure of Conflicts of Interest": When a member has a conflict of interest the member must } \\
\text { disclose the conflict to those involved. } \\
\text { Rule } 6 \text { "Independent Advice": Where a member in public practice is a party to any transaction, not directly }\end{array}$ \\
\hline
\end{tabular}




\begin{tabular}{|c|c|c|}
\hline No & Fundamental Principle & Rules \\
\hline & & $\begin{array}{l}\text { related to the provision of professional services, in which a client of the firm is also a party, the member must } \\
\text { offer the client the opportunity to take independent advice. }\end{array}$ \\
\hline 3 & $\begin{array}{l}\text { The Fundamental } \\
\text { Principle of Competence }\end{array}$ & $\begin{array}{l}\text { - Rule } 7 \text { "Competence": A member who accepts or undertakes professional work must have the competence } \\
\text { necessary to carry out the work. Accordingly, a member must refrain from undertaking or continuing any } \\
\text { assignment which the member is not competent to carry out, unless the member obtains such advice and } \\
\text { assistance as will enable the member to complete the assignment in an efficient, proper and timely manner. } \\
\text { - Rule } 8 \text { "Duty to Maintain Competence": A member has a duty to observe and maintain a high standard of } \\
\text { professional competence throughout the member's professional career. }\end{array}$ \\
\hline 4 & $\begin{array}{c}\text { The Fundamental } \\
\text { Principle of Quality } \\
\text { Performance }\end{array}$ & $\begin{array}{l}\text { - Rule } 9 \text { "Due Care and Diligence": Members must perform all their professional work with due care and } \\
\text { diligence. } \\
\text { - Rule } 10 \text { "Timeliness": Members must complete all their professional obligations in a timely manner. } \\
\text { - Rule } 11 \text { "Compliance with Technical and Professional Standards": Members must comply with the } \\
\text { requirements of the Professional Engagement Standards, the Professional Standards and any other Standards or } \\
\text { pronouncements which the Council may from time to time issue and declare to be mandatory for the purposes of } \\
\text { this provision. }\end{array}$ \\
\hline
\end{tabular}




\begin{tabular}{|c|c|c|}
\hline No & Fundamental Principle & Rules \\
\hline 5 & $\begin{array}{c}\text { The Fundamental } \\
\text { Principle of Professional } \\
\text { Behaviour }\end{array}$ & $\begin{array}{l}\text { - Rule } 12 \text { "Confidentiality": Members must respect the confidentiality of information acquired in the course of } \\
\text { their professional work and must not disclose such information without proper and specific authority or unless } \\
\text { there is a legal or professional right or duty to disclose the information. } \\
\text { - Rule } \mathbf{1 3} \text { "Duty to Report": Any member who has reasonable grounds for suspecting defalcation, fraud, } \\
\text { dishonesty or other unethical behaviour by any other member is under a duty to make a confidential report } \\
\text { immediately to the Chief Executive of the Institute. } \\
\text { - Rule } \mathbf{1 4} \text { "Professional Conduct": Members must conduct themselves with courtesy and consideration towards } \\
\text { all they come into contact with during their professional work, including clients, other members, employers, } \\
\text { staff, third parties and the general public. }\end{array}$ \\
\hline
\end{tabular}


Beside the Code of Ethics, in 2003 the NZICA also issued the Code of Ethics: Independence in Assurance Engagements (effective from January, 2004 as revised in September, 2009). This code deals specifically with the independence of auditors in relation to the assurance engagements they undertake for their clients. The Code of Ethics: Independence in Assurance Engagements requires that all auditors must be, and be seen to be, independent both of mind and in appearance when undertaking specific audit engagements. Here, the preliminary overview of the Code of Ethics: Independence in Assurance Engagements (p. 2) defines independence to include:

(a) Independence of mind - The state of mind that permits the provision of an opinion without being affected by influences that compromise professional judgement, allowing an individual to act with integrity, and exercise objectivity and professional scepticism.

(b) Independence in appearance - The avoidance of facts and circumstances that are so significant that a reasonable and informed third party, having knowledge of all relevant information, including safeguards applied, would reasonably conclude a firm's, or a member of the assurance team's integrity, objectivity or professional scepticism had been compromised.

In order to provide auditors with guidance on how to comply with this independence requirement, the Code of Ethics: Independence in Assurance Engagements provides a framework built on a set of specific principles which identify the particular circumstances in which threats to audit independence may occur. The Code of Ethics: Independence in Assurance Engagements requires that auditors must evaluate the significance of those threats, and, if the threats are other 
than clearly insignificant, identify and apply safeguards to eliminate the threats or reduce them to an acceptable level. In particular, the Code of Ethics: Independence in Assurance Engagements specifies five threats that potentially impair audit independence in a New Zealand context; namely, self-interest, self-review, advocacy, familiarity and intimidation threats. A summary of each threat, its definition and examples are outlined in Table 3.3. 
Table 3.3: Threats for Auditor Independence

\begin{tabular}{|c|c|c|c|}
\hline No & $\begin{array}{c}\text { Threats to } \\
\text { independence }\end{array}$ & Definitions & Examples \\
\hline 1 & $\begin{array}{c}\text { Self-interest } \\
\text { Threat }\end{array}$ & $\begin{array}{l}\text { occurring when a firm, } \\
\text { network firm, or a } \\
\text { member of the assurance } \\
\text { team could benefit from a } \\
\text { financial interest in, or } \\
\text { other self-interest conflict } \\
\text { with, an assurance client. }\end{array}$ & $\begin{array}{l}\text { - a direct financial interest or } \\
\text { material indirect financial } \\
\text { interest in an assurance client; } \\
\text { - a loan or guarantee to or from } \\
\text { an assurance client or any of } \\
\text { its directors or officers; } \\
\text { - undue dependence on total } \\
\text { fees from an assurance client; } \\
\text { - concern about the possibility } \\
\text { of losing the engagement; } \\
\text { - having a close business } \\
\text { relationship with an assurance } \\
\text { client; } \\
\text { - potential employment with an } \\
\text { assurance client; and } \\
\text { - contingent fees relating to } \\
\text { assurance engagements. }\end{array}$ \\
\hline 2 & $\begin{array}{c}\text { Self-review } \\
\text { Threat }\end{array}$ & $\begin{array}{l}\text { - any product or judgement } \\
\text { of a previous assurance } \\
\text { engagement or non- } \\
\text { assurance engagement } \\
\text { needs to be re-evaluated } \\
\text { in reaching conclusions } \\
\text { on the assurance } \\
\text { engagement; or } \\
\text { when a member of the } \\
\text { assurance team was } \\
\text { previously a director or } \\
\text { officer of the assurance } \\
\text { client, or was an }\end{array}$ & $\begin{array}{l}\text { - a member of the assurance } \\
\text { team being, or having recently } \\
\text { been, a director or officer of } \\
\text { the assurance client; } \\
\text { - a member of the assurance } \\
\text { team being, or having recently } \\
\text { been, an employee of the } \\
\text { assurance client in a position } \\
\text { to exert direct and significant } \\
\text { influence over the subject } \\
\text { matter of the assurance } \\
\text { engagement; } \\
\text { performing services for an }\end{array}$ \\
\hline
\end{tabular}




\begin{tabular}{|c|c|c|c|}
\hline & & $\begin{array}{l}\text { employee in a position to } \\
\text { exert direct and } \\
\text { significant influence over } \\
\text { the subject matter of the } \\
\text { assurance engagement. }\end{array}$ & $\begin{array}{l}\text { assurance client that directly } \\
\text { affect the subject matter of the } \\
\text { assurance engagement; and } \\
\text { - preparation of original data } \\
\text { used to generate financial } \\
\text { statements or preparation of } \\
\text { other records that are the } \\
\text { subject matter of the assurance } \\
\text { engagement. }\end{array}$ \\
\hline 3 & $\begin{array}{c}\text { Advocacy } \\
\text { Threat }\end{array}$ & $\begin{array}{l}\text { - occurring when a firm, a } \\
\text { member of the assurance } \\
\text { team, or a member of the } \\
\text { network firm, as } \\
\text { applicable, promotes, or } \\
\text { may be perceived to } \\
\text { promote, an assurance } \\
\text { client's position or } \\
\text { opinion to the point that } \\
\text { objectivity may, or may } \\
\text { be perceived to be, } \\
\text { compromised. Such may } \\
\text { be the case if a firm or a } \\
\text { member of the assurance } \\
\text { team were to subordinate } \\
\text { their judgement to that of } \\
\text { the client. }\end{array}$ & $\begin{array}{l}\text { - dealing in, or being a promoter } \\
\text { of, shares or other securities of } \\
\text { an assurance client; and } \\
\text { - acting as an advocate on } \\
\text { behalf of an assurance client } \\
\text { in litigation or in resolving } \\
\text { disputes with third parties. }\end{array}$ \\
\hline 4 & $\begin{array}{c}\text { Familiarity } \\
\text { Threat }\end{array}$ & $\begin{array}{l}\text { - occurring when, by virtue } \\
\text { of a close relationship } \\
\text { with an assurance client, } \\
\text { its directors, officers or } \\
\text { employees, a firm, or a } \\
\text { member of the assurance } \\
\text { team or network firm, as } \\
\text { applicable, becomes too }\end{array}$ & $\begin{array}{l}\text { - a member of the assurance } \\
\text { team having an immediate } \\
\text { family member or close family } \\
\text { member who is a director or } \\
\text { officer of the assurance client; } \\
\text { - a member of the assurance } \\
\text { team having an immediate } \\
\text { family member or close family }\end{array}$ \\
\hline
\end{tabular}




\begin{tabular}{|c|c|c|c|}
\hline & & $\begin{array}{l}\text { sympathetic to the } \\
\text { client's interests. }\end{array}$ & $\begin{array}{l}\text { member who, as an employee } \\
\text { of the assurance client, is in a } \\
\text { position to exert direct and } \\
\text { significant influence over the } \\
\text { subject matter of the assurance } \\
\text { engagement; } \\
\text { - a former partner of the firm } \\
\text { being a director, officer of the } \\
\text { assurance client or an } \\
\text { employee in a position to exert } \\
\text { direct and significant } \\
\text { influence over the subject } \\
\text { matter of the assurance } \\
\text { engagement; } \\
\text { long association of a senior } \\
\text { member of the assurance team } \\
\text { with the assurance client; and } \\
\text { acceptance of gifts or } \\
\text { hospitality, unless the value is } \\
\text { clearly insignificant, from the } \\
\text { assurance client, its directors, } \\
\text { officers or employees. }\end{array}$ \\
\hline 5 & $\begin{array}{c}\text { Intimidation } \\
\text { Threat }\end{array}$ & $\begin{array}{l}\text { Occurring when a member } \\
\text { of the assurance team may } \\
\text { be deterred from acting } \\
\text { objectively and exercising } \\
\text { professional scepticism by } \\
\text { threats, whether actual or } \\
\text { perceived, from the } \\
\text { directors, officers or } \\
\text { employees of an assurance } \\
\text { client }\end{array}$ & $\begin{array}{l}\text { - threat of replacement over a } \\
\text { disagreement with the } \\
\text { application of an accounting } \\
\text { principle; and } \\
\text { - pressure to reduce } \\
\text { inappropriately the extent of } \\
\text { work performed in order to } \\
\text { reduce fees. }\end{array}$ \\
\hline
\end{tabular}

Source: Code of Ethics: Independence in Assurance Engagements 
The Code of Ethics: Independence in Assurance Engagements also requires that if threats are identified, other than those that are clearly insignificant, appropriate safeguards must be identified and applied to eliminate the threats or reduce them to an acceptable level. Safeguards may come from three broad categories: (1) safeguards created by the profession, legislation or regulation; (2) safeguards within the assurance client; and (3) safeguards within the audit firm's own systems and procedures. In particular, the safeguards provided by paragraphs 58,59 and 60 of the Code of Ethics: Independence in Assurance Engagements include:

1. Safeguards created by the profession, legislation or regulation:

- educational, training and experience requirements for entry into the profession;

- continuing education requirements;

- professional standards, monitoring and disciplinary processes;

- external review of an audit firm's quality control system; and

- legislation governing the independence requirements of the audit firm.

2. Safeguards created by audit client:

- when management appoints the audit firm, persons other than management must ratify or approve the appointment;

- that competent employees are able to make managerial decisions;

- policies and procedures that emphasise the assurance client's commitment to fair financial reporting;

- internal procedures that ensure objective choices in commissioning nonassurance engagements; and

- a corporate governance structure, such as an audit committee, that provides appropriate oversight and communications regarding an audit firm's services. 
In particular, paragraph 61 of the Code of Ethics: Independence in Assurance Engagements stresses the role of the audit committee in ensuring the independence of the relationship between the auditor and the client firm's management. The Code of Ethics: Independence in Assurance Engagements, therefore, requires that audit committees must be independent of the client firm's management.

\section{Safeguards created by audit firms:}

- leadership that stresses the importance of independence and the expectation that members of assurance teams will act in the public interest;

- policies and procedures to implement and monitor the quality control of assurance engagements;

- document independence policies regarding the identification of threats to independence, the evaluation of the significance of these threats and the identification and application of safeguards to eliminate or reduce the threats, other than those that are clearly insignificant, to an acceptable level;

- internal policies and procedures to monitor compliance with audit firm policies and procedures as they relate to independence;

- policies and procedures that will enable the identification of interests or relationships between the audit firm or members of the assurance team and assurance clients;

- policies and procedures to monitor and, if necessary, manage the reliance on revenue received from a single assurance client;

- using different partners and teams with separate reporting lines for the provision of non-assurance services to an assurance client;

- policies and procedures to prohibit individuals who are not members of the assurance team from influencing the outcome of the assurance engagement; 
- timely communication of a firm's policies and procedures, and any changes thereto, to all partners and professional staff, including appropriate training and education thereon;

- designating a member of senior management of the audit firm as responsible for overseeing the adequate functioning of the safeguarding system;

- a means of advising partners and professional staff of those assurance clients and related entities from which they must be independent;

- a disciplinary mechanism to promote compliance with policies and procedures;

- policies and procedures to empower staff to communicate to senior levels within the audit firm any issue of independence and objectivity that concerns them, including informing staff of the procedures open to them.

Furthermore, the Code of Ethics: Independence in Assurance Engagements also provides that an auditor and/or audit firm must comply with specific ethical standards in particular circumstances and/or when specific relationships arise. The list of circumstances and relationships covered by the Code of Ethics: Independence in Assurance Engagements is summarised in Table 3.4. Ethical issues that arise in relation to the level/and or determination of audit fees, non-audit fees and audit firm appointment will be discussed in further detail in sections 3.3.1, 3.3.2, 3.3.3 and 3.3.4 of this thesis. 
Table 3.4: Lists of Threats for Auditor Independence Acknowledged by the NZICA

\begin{tabular}{|l|l|}
\hline No & \multicolumn{1}{|c|}{ Lists of threats } \\
\hline 1 & A loan from or a guarantee for a loan by an assurance client. \\
\hline 2 & Close Business Relationships with Assurance Clients. \\
\hline 3 & Family and Personal Relationships. \\
\hline 4 & Employment with Assurance Clients. \\
\hline 5 & Recent Service with Assurance Clients. \\
\hline 6 & Serving as an Officer or Director on the Board of Directors of Assurance Clients. \\
\hline 7 & Long Association of Senior Personnel with Assurance Clients. \\
\hline 8 & Provision of Non-Assurance Services to Audit Clients. \\
\hline 8.1 & Preparing Accounting Records and Financial Statements \\
\hline 8.2 & Valuation Services \\
\hline 8.3 & Provision of Taxation Services \\
\hline 8.4 & Provision of Internal Audit Services \\
\hline 8.5 & Provision of Information Technology Systems Services \\
\hline 8.6 & Temporary Staff Assignments \\
\hline 8.7 & Provision of Litigation Support Services \\
\hline 8.8 & Provision of Legal Services \\
\hline 8.9 & Recruiting Senior Management \\
\hline 8.10 & Corporate Finance and Similar Activities \\
\hline 9 & Fees and Pricing. \\
\hline 9.1 & Fee dependence \\
\hline 9.2 & Fees - Overdue \\
\hline 9.3 & Fees - Low Balling \\
\hline 9.4 & Contingent Fees \\
\hline 10 & Gifts and Hospitality. \\
\hline
\end{tabular}

Source: Code of Ethics: Independence in Assurance Engagements 


\subsubsection{Provision of Non-Audit Services in New Zealand}

The Code of Ethics: Independence in Assurance Engagements notes that the provision of non-audit services to audit clients may create threats to the independence of the audit team and/or audit firm. However, the Code also recognises the benefits that non-audit services may contribute to both audit clients and audit firms. For example, audit clients derive benefits from an auditor's experience if they have a good understanding of the audit client's business, and then apply their knowledge and skills in other non-audit services provided to the audit client. Furthermore, the provision of non-audit services will often allow the audit team to gain more information about the audit client's business and operations and this may assist the audit team to better understand the audit client's procedures and controls as well as the financial and other risks which the audit client faces. Given this, the Code of Ethics: Independence in Assurance Engagements allows audit firms to provide almost any form of non-audit services but requires that the audit firm makes an evaluation of whether the provision of the particular non-audit services would create a threat to the audit team's and/or audit firm's independence. In situations where the threat to audit independence is clearly not insignificant, the audit firm must apply safeguards to reduce or eliminate the threat to an acceptable level. If the audit firm fails or is unable to reduce the threats to an acceptable level, then the audit firm must decline the non-audit services engagement. The procedures used to assess the threats to independence posed by the provision of a particular non-audit service are summarised in Figure 3.3.

Furthermore, the Code of Ethics: Independence in Assurance Engagements also provides a list of non-audit services that may pose a significant threat to auditor independence and suggests safeguards for each situation. However, the Code of Ethics: Independence in Assurance Engagements also notes that it is impossible to catalogue all the situations that may compromise auditor independence and nor is 
practicable to draw up an all-inclusive list of safeguards for these situations. In practice, the audit firm and the members of the audit team will be required to assess the implications of similar, but different, circumstances and relationships and then determine whether safeguards, including the safeguards summarised in Table 3.5, can be applied in a way that satisfactorily addresses the threats to the audit firm's/and or audit team's independence. Paragraphs 70 and 71 of the Code of Ethics: Independence in Assurance Engagements provide further conceptual guidance to assist in this process. Thus, the list provided by the Code of Ethics: Independence in Assurance Engagements gives exemplar safeguards only and is not meant to be exhaustive. The situations covered by the list include:

Figure 3.3: The Procedures for Audit Firms to Accept

\section{a Non-audit Service Engagement}

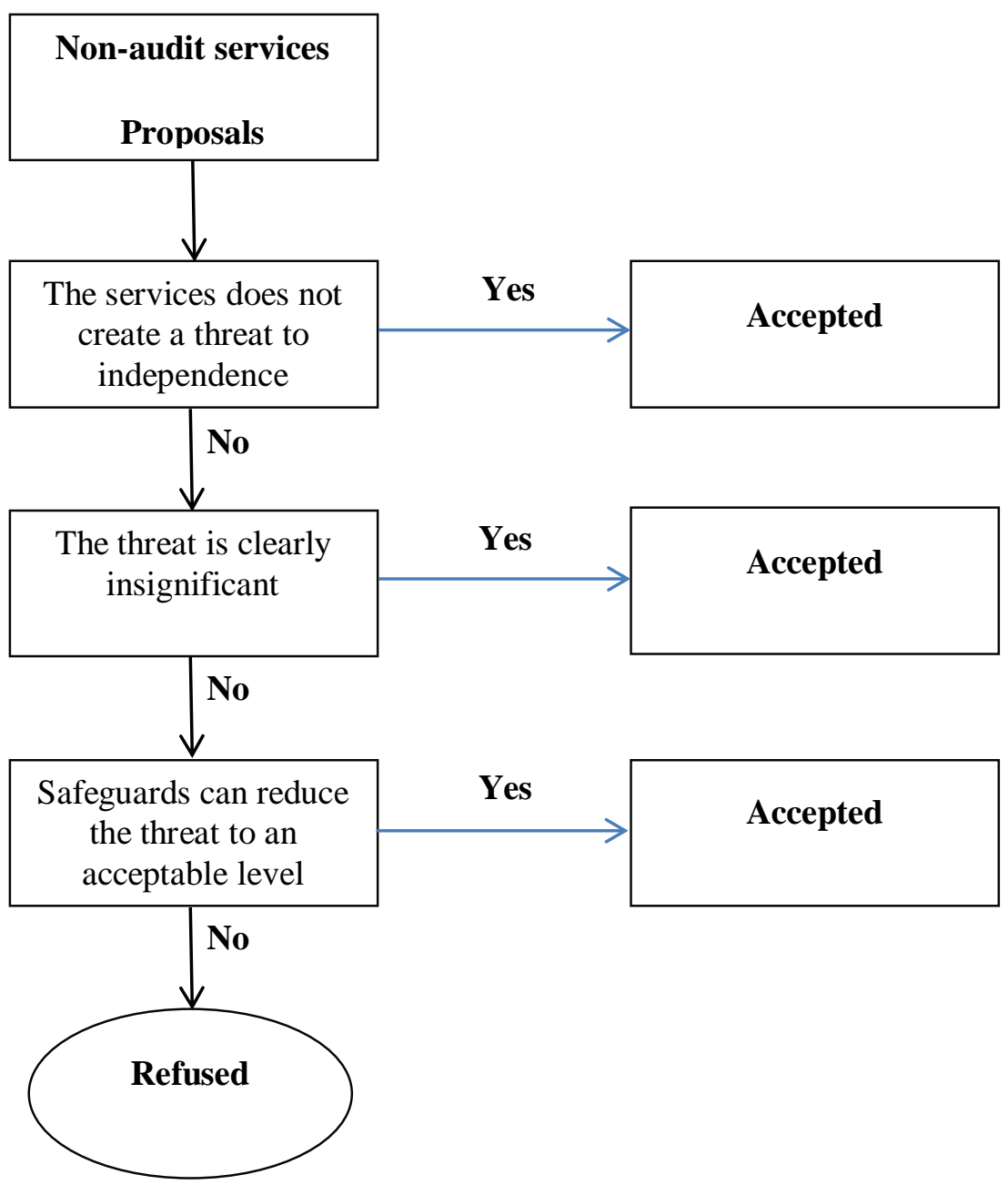


Table 3.5: Safeguards for Reducing Threats of Non-audit Services

\begin{tabular}{|c|c|c|c|}
\hline No & Non-audit service & Descriptions of services & Safeguards \\
\hline 1 & $\begin{array}{l}\text { Preparing Accounting } \\
\text { Records and } \\
\text { Financial Statements }\end{array}$ & $\begin{array}{l}\text { Assisting an audit client in matters such as preparing } \\
\text { accounting records or financial statements. }\end{array}$ & $\begin{array}{l}\text { Banned with only a few limited exceptional situations such as: } \\
\text { (a) the services do not involve the exercise of judgement; } \\
\text { (b) the divisions or subsidiaries for which the service is } \\
\text { provided are collectively immaterial to the audit client, or the } \\
\text { services provided are collectively immaterial to the division or } \\
\text { subsidiary; and } \\
\text { (c) the fees to the firm, or network firm, from such services are } \\
\text { collectively clearly insignificant. } \\
\text { If such services are provided, all of the following safeguards } \\
\text { must be applied: } \\
\text { (a) the firm, or network firm, must not assume any managerial } \\
\text { role nor make any managerial decisions; } \\
\text { (b) the issuer audit client must accept responsibility for the }\end{array}$ \\
\hline
\end{tabular}




\begin{tabular}{|c|c|c|c|}
\hline & & & $\begin{array}{l}\text { results of the work; } \\
\text { (c) personnel providing the services must not participate in the } \\
\text { audit. }\end{array}$ \\
\hline 2 & Valuation Services & $\begin{array}{l}\text { A valuation comprises the making of assumptions with } \\
\text { regard to future developments, the application of } \\
\text { certain methodologies and techniques, and the } \\
\text { combination of both in order to compute a certain } \\
\text { value, or range of values, for an asset, a liability or for } \\
\text { a business as a whole. }\end{array}$ & $\begin{array}{l}\text { (a) involving an additional member of the firm who was not a } \\
\text { member of the assurance team to review the work done or } \\
\text { otherwise advise as necessary; } \\
\text { (b) confirming with the audit client their understanding of the } \\
\text { underlying assumptions of the valuation and the methodology } \\
\text { to be used and obtaining approval for their use; } \\
\text { (c) obtaining the audit client's acknowledgement of } \\
\text { responsibility for the results of the work performed by the } \\
\text { firm; and } \\
\text { (d) making arrangements so that personnel providing such } \\
\text { services do not participate in the audit engagement. }\end{array}$ \\
\hline 3 & $\begin{array}{l}\text { Provision of Taxation } \\
\text { Services }\end{array}$ & $\begin{array}{l}\text { Taxation services comprise a broad range of services, } \\
\text { including compliance, planning, provision of formal } \\
\text { taxation opinions and assistance in the resolution of tax } \\
\text { disputes. }\end{array}$ & $\begin{array}{l}\text { (a) members of the assurance team are not involved in } \\
\text { providing the service; } \\
\text { (b) in relation to the advice provided, the audit client makes the }\end{array}$ \\
\hline
\end{tabular}




\begin{tabular}{|c|c|c|c|}
\hline & & & $\begin{array}{l}\text { ultimate decision or, in relation to the transactions, the service } \\
\text { involves the execution of what has been decided by the audit } \\
\text { client. }\end{array}$ \\
\hline 4 & $\begin{array}{l}\text { Provision of Internal } \\
\text { Audit Services }\end{array}$ & $\begin{array}{l}\text { Internal audit services may comprise an extension of } \\
\text { the firm's audit service beyond requirements of } \\
\text { generally accepted auditing standards, assistance in the } \\
\text { performance of a client's internal audit activities or } \\
\text { outsourcing of the activities. }\end{array}$ & $\begin{array}{l}\text { (a) the audit client is responsible for internal audit activities } \\
\text { and acknowledges its responsibility for establishing, } \\
\text { maintaining and monitoring the system of internal controls; } \\
\text { (b) the audit client designates a competent employee, } \\
\text { preferably within senior management, to be responsible for } \\
\text { internal audit activities; } \\
\text { (c) the audit client, the audit committee or supervisory body } \\
\text { approves the scope, risk and frequency of internal audit work; } \\
\text { (d) the audit client is responsible for evaluating and } \\
\text { determining which recommendations of the firm should be } \\
\text { implemented; } \\
\text { (e) the audit client evaluates the adequacy of the internal audit } \\
\text { procedures performed and the findings resulting from the } \\
\text { performance of those procedures by, among other things, }\end{array}$ \\
\hline
\end{tabular}




\begin{tabular}{|c|c|c|c|}
\hline & & & $\begin{array}{l}\text { obtaining and acting on reports from the firm; and } \\
\text { (f) the findings and recommendations resulting from the } \\
\text { internal audit activities are reported appropriately to the audit } \\
\text { committee or supervisory body. }\end{array}$ \\
\hline 5 & $\begin{array}{l}\text { Provision of } \\
\text { Information } \\
\text { Technology } \\
\text { Systems } \\
\text { Services }\end{array}$ & $\begin{array}{l}\text { The provision of services by a firm or network firm to } \\
\text { an audit client that involve the design and } \\
\text { implementation of financial information technology } \\
\text { systems that are used to generate information forming } \\
\text { part of a client's financial statements. }\end{array}$ & $\begin{array}{l}\text { (a) the audit client acknowledges its responsibility for } \\
\text { establishing and monitoring a system of internal controls; } \\
\text { (b) the audit client designates a competent employee, } \\
\text { preferably within senior management, with the responsibility } \\
\text { to make all management decisions with respect to the design } \\
\text { and implementation of the hardware or software system; } \\
\text { (c) the audit client makes all management decisions with } \\
\text { respect to the design and implementation process; } \\
\text { (d) the audit client evaluates the adequacy and results of the } \\
\text { design and implementation of the system; and } \\
\text { (e) the audit client is responsible for the operation of the } \\
\text { system (hardware and/or software) and the data used or } \\
\text { generated by the system. }\end{array}$ \\
\hline
\end{tabular}




\begin{tabular}{|c|c|c|c|}
\hline 6 & $\begin{array}{l}\text { Temporary } \\
\text { Assignments }\end{array}$ & $\begin{array}{l}\text { The lending of staff by a firm, or a network firm, to an } \\
\text { audit client. }\end{array}$ & $\begin{array}{l}\text { Such assistance may be given (particularly in emergency } \\
\text { situations) but only on the understanding that the firm's, or } \\
\text { network firm's, personnel will not be involved in: (1) making } \\
\text { management decisions; (2) approving or signing agreements or } \\
\text { other similar documents; or (3) exercising discretionary } \\
\text { authority to commit the client. Safeguards that must be applied } \\
\text { in all circumstances to reduce any threats to an acceptable level } \\
\text { include: } \\
\text { (a) the firm's staff providing the assistance must not be given } \\
\text { audit responsibility for any function or activity that they } \\
\text { performed or supervised during their temporary staff } \\
\text { assignment; and } \\
\text { (b) the audit client must acknowledge its responsibility for } \\
\text { directing and supervising the activities of the firm's, or } \\
\text { network firm's, personnel. }\end{array}$ \\
\hline 7 & $\begin{array}{l}\text { Provision } \\
\text { Litigation } \\
\text { Services }\end{array}$ & $\begin{array}{l}\text { Litigation support services may include such activities } \\
\text { as acting as an expert witness, calculating estimated } \\
\text { damages or other amounts that might become } \\
\text { receivable or payable as the result of litigation or other }\end{array}$ & $\begin{array}{l}\text { (a) policies and procedures to prohibit individuals assisting the } \\
\text { audit client from making managerial decisions on behalf of the } \\
\text { client; }\end{array}$ \\
\hline
\end{tabular}




\begin{tabular}{|c|c|c|c|}
\hline & & $\begin{array}{l}\text { legal dispute, and assistance with document } \\
\text { management and retrieval in relation to a dispute or } \\
\text { litigation. }\end{array}$ & $\begin{array}{l}\text { (b) using professionals who are not members of the assurance } \\
\text { team to perform the service; or } \\
\text { (c) the involvement of others, such as independent experts. }\end{array}$ \\
\hline 8 & $\begin{array}{l}\text { Provision of Legal } \\
\text { Services }\end{array}$ & $\begin{array}{l}\text { Legal services are defined as any services for which } \\
\text { the person providing the services must either be } \\
\text { admitted to practise before the courts of the } \\
\text { jurisdiction in which such services are to be provided, } \\
\text { or have the required legal training to practise law. }\end{array}$ & $\begin{array}{l}\text { Legal services to support an audit client in the execution of a } \\
\text { transaction may create self-review threats; however, safeguards } \\
\text { may be available to reduce these threats to an acceptable level. } \\
\text { Such a service would not generally impair independence, } \\
\text { provided that: } \\
\text { (a) members of the assurance team are not involved in } \\
\text { providing the service; } \\
\text { (b) in relation to the advice provided, the audit client makes the } \\
\text { ultimate decision or, in relation to the transactions, the service } \\
\text { involves the execution of what has been decided by the audit } \\
\text { client. } \\
\text { Threats from other legal services may be reduced by the } \\
\text { following safeguards: } \\
\text { (a) policies and procedures to prohibit individuals assisting the }\end{array}$ \\
\hline
\end{tabular}




\begin{tabular}{|c|c|c|c|}
\hline & & & $\begin{array}{l}\text { audit client from making managerial decisions on behalf of the } \\
\text { client; or } \\
\text { (b) using professionals who are not members of the assurance } \\
\text { team to perform the service. }\end{array}$ \\
\hline 9 & $\begin{array}{l}\text { Recruiting Senior } \\
\text { Management }\end{array}$ & $\begin{array}{l}\text { The recruitment of senior management for an } \\
\text { assurance client. }\end{array}$ & $\begin{array}{l}\text { The audit firm must not make management decisions and the } \\
\text { decision as to whom to hire must be left to the client. }\end{array}$ \\
\hline 10 & $\begin{array}{l}\text { Corporate Finance } \\
\text { and Similar Activities }\end{array}$ & $\begin{array}{l}\text { The provision of corporate finance services including } \\
\text { advising or assisting an audit client in corporate } \\
\text { finance policies and procedures. }\end{array}$ & $\begin{array}{l}\text { Banned from some services such as: promoting, dealing in, or } \\
\text { underwriting of an assurance client's shares; or committing the } \\
\text { assurance client to the terms of a transaction; or consummating } \\
\text { a transaction on behalf of the client. } \\
\text { Other corporate finance services such as: assisting in } \\
\text { identifying or introducing a client to possible sources of capital } \\
\text { that meet the client specifications or criteria, and providing } \\
\text { structuring advice and assisting a client in analysing the } \\
\text { accounting effects of proposed transactions. In these situations } \\
\text { the following safeguards can be applied: } \\
\text { (a) policies and procedures to prohibit individuals assisting the } \\
\text { assurance client from making managerial decisions on behalf }\end{array}$ \\
\hline
\end{tabular}




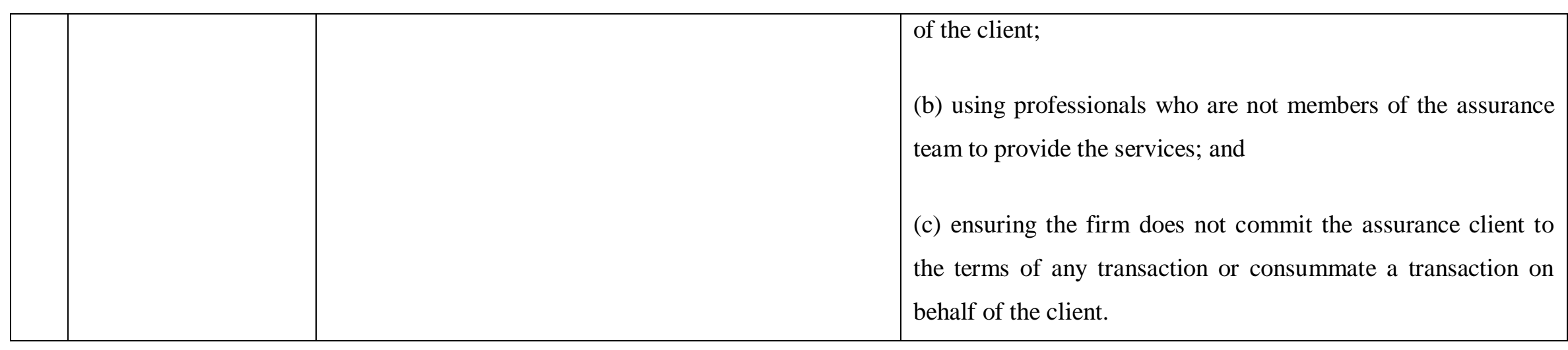

Source: the Code of Ethics: Independence in Assurance Engagement 


\subsubsection{The Appointment and Replacement of Auditors in New Zealand}

Section 196 of the New Zealand Companies Act (1993) makes the general provision that every company must appoint an auditor at the annual meeting of its shareholders to audit the financial statements of the company and/or group financial statements, for the next ensuing accounting period. However, there are occasions in which the auditor may be appointed either by the company's Board of Directors or the Registrar of Companies. Thus, section 201 of the Companies Act provides that the first auditor of a company may be appointed by the directors of the company before the company's first annual meeting, and, if so appointed, the auditor will hold office until the conclusion of that meeting. Moreover, if at the annual meeting of the company no auditor is appointed and the office of auditor is not filled within one calendar month of the vacancy occurring, then the Registrar of Companies may unilaterally appoint an auditor for the company. In practice, an auditor of a company will be automatically reappointed at an annual meeting of the company unless: (1) the auditor is not qualified for appointment; (2) the company passes a resolution at the meeting appointing another auditor; (3) the company passes a resolution under section 196 of the Companies Act that no auditor be appointed, or (4) the auditor has given notice to the company that they do not wish to be reappointed. Section 202 of the Companies Act provides that a company must not appoint a new auditor in place of an incumbent auditor who is qualified for reappointment, unless the incumbent auditor has been given a reasonable opportunity to make representations to the shareholders on the appointment of an alternative auditor. This representation may occur either in writing or by the incumbent auditor or by their nominated representative speaking at the shareholders' meeting. In contrast, an auditor has the right to resign at any time by giving written notice to the company's Board of Directors, and the company must, as soon as practicable, notify its shareholders of the auditor's resignation. 


\subsubsection{Audit Fee Negotiation in New Zealand}

Section 197 of the Companies Act also provides that the fees and expenses of an auditor of a company shall normally be fixed by the company at the annual meeting of the company. However, Karen et al. (2011) note that whilst the procedures for determining an appropriate audit fee are normally approved by the shareholders of the company in annual meeting, the exact details are invariably left to further negotiations between members of the company's Board of Directors, the company's audit committee and the incumbent auditor themselves. Karen et al. (2011, p. 70) also note that whilst an "auditor may return to the Board [in the event that] unexpected costs arise, the audit firm would be wise to calibrate its fees as carefully as possible at the time [the] contract is [written in order] to avoid [subsequent] losses and conflicts".

The negotiation of audit fees in New Zealand must also comply with the Code of Ethics: Independence in Assurance Engagements (2003, paragraph 175-182) as issued by the New Zealand Institute of Chartered Accountants (NZICA). Amongst other reasons, the Code of Ethics was put into place by the NZICA in order to ensure that the audit fees negotiated between auditors and their client firms do not compromise or threaten an auditor's independence. Here there was a particular concern that if the audit fee paid by a particular client represented a large proportion of the total audit fees received by an audit firm, then the audit firm may have incentives to compromise their independence in order to insure that they keep the audit client and the audit fees associated with the audit engagement. Whilst the NZICA's Code of Ethics does not identify a specific amount or proportion at which concerns might begin to arise about an auditor's independence, paragraph 175 of the Code of Ethics requires that an audit firm must apply special safeguards to reduce the threat of fee dependence if the threat is seen as significant by the affected audit firm. 
The safeguards include: (1) discussing the extent and nature of fees charged with the client firm's audit committee or others charged with responsibility for the client firm's governance procedures; (2) taking steps to reduce the extent of economic dependence on the audit fee paid by the affected client firm; (3) external quality control reviews; and (4) consulting a third party, such as a professional regulatory body or another NZICA member.

Second, paragraph 179 of the NZICA's Code of Ethics also makes provision for the "low-balling" issues which may arise when an audit firm negotiates a significantly lower audit fee than that charged by a predecessor audit firm and/or the level of the audit fees offered by other audit firms. In particular, paragraph 179 of the Code of Ethics provides that a client firm can only accept a lower audit fee offer if: (1) the audit firm is able to demonstrate that the appropriate time and qualified staff are allocated to the audit assignment; and (2) all applicable assurance standards, guidelines and quality control procedures are being complied with. Paragraph 179 of the Code of Ethics also provides that the audit fee negotiated between an auditor and their client firm is not to be contingent on the outcome or result of any particular transaction or item appearing in the client firm's financial statements or the result of audit work performed by the auditor for the client firm.

\subsubsection{Audit Opinions in New Zealand}

In October 2009, the NZICA adopted the auditing standards that have been issued by the International Federation of Accountants (IFAC). Consistent with these international auditing standards, the NZICA allowed auditors to issue two basic types of audit opinion; namely an unmodified or a modified audit opinion. These replaced the former "unqualified" and "qualified" audit opinions that had formerly been endorsed by the NZICA. Moreover, there were slight changes of detail in the structure and form of the audit opinions which could be issued by auditors in New 
Zealand after the adoption of the IFAC standards. Before October 2009, New Zealand Audit Standards provided that audit opinions must take one of four specific forms. First, an unqualified opinion is issued when the auditor concludes that the financial statements give a true and fair view or are presented fairly, in all material respects, in accordance with the applicable financial reporting frameworks (ISA-700R, paragraph 39). An "emphasis of matter" paragraph can be added to an unqualified report if an auditor finds any unusual issues that may be of particular importance to the users of the audited financial statements. However, the "emphasis of matter" paragraph can only be used on relatively rare occasions and even then, only to avoid confusion on the part of users of financial statements. For instance, Karen et al. (2011, p. 412) note that an "emphasis of matter" paragraph may be used in a situation in which:

- there is fundamental uncertainty about the entity's ability to continue as a going concern;

- a subsequent event (following the balance sheet date) that is so material that it should be immediately disclosed to the users of the financial statements;

- the audit client has applied an early or unusual but nonetheless acceptable, accounting principle, or

- an infrastructure asset exists and is listed and depreciated on the audit client's balance sheet but does not actually belong to the audit client.

In October 2009, New Zealand became the first country in the world to adopt all 36 international auditing standards issued by IFAC. Besides renaming audit opinions as unmodified and/or modified rather than qualified and/or unqualified, there were also changes in the nature of each type of audit opinion. In particular, International Statements in Auditing (New Zealand) [ISA (NZ)] 700 provides that an auditor shall express an unmodified opinion when they conclude that the financial 
statements are prepared, in all material respects, in accordance with the applicable financial reporting framework. ISA (NZ) 700 also provides that if the auditor considers it necessary to draw users' attention to a matter presented or disclosed in the financial statements that, in the auditor's judgement, is of such importance that it is fundamental to users' understanding of the financial statements, then the auditor shall include an "emphasis of matter" paragraph in the audit report provided only that the auditor has obtained sufficient appropriate audit evidence that the matter is not materially misstated in the financial statements. Here, ISA (NZ) 706 provides some of the circumstances where the auditor may consider it necessary to include an "emphasis of matter" paragraph in their audit report:

- an uncertainty relating to the future outcome of exceptional litigation or regulatory action.

- early application in advance of its effective date (where permitted) of a new accounting standard that has a pervasive effect on the financial statements.

- a major catastrophe that has had, or continues to have, a significant effect on the entity's financial position.

Moreover, if the auditor concludes that, based on the audit evidence obtained, the financial statements as a whole are not free from material misstatement, or if the auditor is unable to obtain sufficient appropriate audit evidence to conclude that the financial statements as a whole are free from material misstatement, then the auditor must express one of the three types of modified audit opinions:

- a qualified opinion if either: (1) The auditor, having obtained sufficient appropriate audit evidence, concludes that misstatements, individually or in the aggregate, are material, but not pervasive, to the financial statements; or (2) the auditor is unable to obtain sufficient appropriate audit evidence on which to base the opinion, but the auditor concludes that the possible effects 
on the financial statements of undetected misstatements, if any, could be material but are not pervasive.

- an adverse opinion when the auditor, having obtained sufficient appropriate audit evidence, concludes that misstatements, individually or in the aggregate, are both material and pervasive to the financial statements.

- a disclaimer opinion if the auditor is unable to obtain sufficient appropriate audit evidence on which to base their opinion, and the auditor concludes that the possible effects on the financial statements of undetected misstatements, if any, could be both material and pervasive.

A summary of the modified audit opinions which may be issued by an auditor under IFAC auditing standards are contained in Table 3.6:

Table 3.6: Types of Modified Opinions

\begin{tabular}{|c|c|c|}
\hline \multirow{2}{*}{$\begin{array}{c}\text { Nature of Matter Giving } \\
\text { Rise to the Modification }\end{array}$} & \multicolumn{2}{|c|}{$\begin{array}{c}\text { Auditor's Judgement about the Pervasiveness of the } \\
\text { Effects or Possible Effects on the Financial Statements }\end{array}$} \\
\cline { 2 - 3 } & Material but Not Pervasive & Material and Pervasive \\
\hline $\begin{array}{c}\text { Financial statements are } \\
\text { materially misstated }\end{array}$ & Qualified opinion & Adverse opinion \\
\hline $\begin{array}{c}\text { Inability to obtain sufficient } \\
\text { appropriate audit evidence }\end{array}$ & Qualified opinion & Disclaimer opinion \\
\hline
\end{tabular}

Source: ISA (NZ) 705, part AI

\subsection{New Zealand Stock Exchange}

The New Zealand Companies Act (1993) provides the framework for the formation, governance and winding up of all New Zealand companies. Under section 15 of the Companies Act, a company is defined as a legal entity in its own right, separate from its shareholders with continuity of existence until it is removed from the New Zealand Register of Companies. Moreover, sections 10 and 42 of the Companies 
Act provide that each company may be owned by one or more shareholders and that the company may issue shares at any time, to any person, and in any number as long as the issue of shares is in conformity with the Companies Act and the constitution of the company. Moreover, section 63 of the Companies Act provides that a company's shares may be listed on one or more stock exchanges. Here, the New Zealand Stock Exchange comprises three boards, namely:

- The New Zealand Stock Market (NZSX) which is comprised of larger and more actively traded stocks;

- The New Zealand Alternative Market (NZAX) which is comprised of smaller and growing company stocks, and

- The New Zealand Debt Market (NZDX) which is comprised of corporate and government bonds and fixed-income securities.

The three boards are managed by NZX Limited (NZX) which is a limited company that is itself listed on the NZSX and which was incorporated on 31 December 2002 but has predecessor organisations dating back to the 1870s. Whilst the NZX Limited prescribes listing requirements for companies listed on the stock exchange it is the New Zealand Financial Markets Authority and its predecessor organisations (e.g. until 1 May, 2011 The New Zealand Securities Commission) that has had and continues to have responsibility for the enforcement, monitoring and market oversight of securities markets, the licensing of financial advisors and auditors and promoting public understanding of investments.

\subsection{Conclusion}

Chapter three summarises the current status of audit research in New Zealand. I note in particular that whilst the New Zealand audit market has much in common with the audit markets of other advanced industrialised countries, it also has some 
unique characteristics of its own. First, the audit market in New Zealand is concentrated in the two largest cities of Auckland and Wellington and is relatively small when compared to the audit markets of other advanced industrialised countries. This potentially at least can create greater opportunities for a closer (and less objective) relationship between New Zealand auditors and their client firms. Moreover, New Zealand has a low private litigation environment (Dunstan et al. 2011) and this provides additional incentives for auditors to be less meticulous about insuring both the quality of their audit procedures and their audit independence. Finally, until 2011 when the New Zealand government enacted the New Zealand Auditor Regulation Act, there had been a strong perception amongst the New Zealand public, business community, investors and others that the regulation of the auditing profession in New Zealand was less rigorous than in other advanced industrialised countries. However, with the passage of the New Zealand Auditor Regulation Act in 2011, the regulation of the auditing profession in New Zealand is now conducted by an independent government funded body and the perception that the regulation of the auditing profession is less rigorous than in other advanced industrialised countries is gradually abating. 


\section{CHAPTER 4 HYPOTHESES DEVELOPMENT}

In this chapter, I use the summary of the literature provided in Chapter two of the thesis and the summary of the New Zealand research setting provided in Chapter three to formulate hypotheses about the relationship between the audit factors identified in the literature and the level of discretionary accruals (DACCs) which one would expect to find in a New Zealand context. Specifically, in section 4.1 the hypotheses I formulate in this chapter address the potential impact of six important audit factors on the level of DACCs; namely: (1) whether the audit is conducted by a Big 4 audit firm; (2) whether the audit office is located in Auckland or Wellington; (3) the provision of non-audit services; (4) whether the audit is conducted during the audit busy season; (5) whether the client firm changes auditor, and (6) whether the client firm receives a qualified or conditional audit opinion. I then move on to Section 4.2 which develops an important hypothesis that relates the level of DACCs in the current year to the audit fees paid by client firms in subsequent years. In particular based on the methodological deficiencies and potential biases of prior empirical research and the current regulations governing the determination of audit fees in New Zealand, I hypothesise that the agreed audit fee for the next ensuing year is likely to reflect information about the level of earnings management in prior years and of how the issues arising out of these 
earnings management procedures have been resolved between the client firm and the audit firm ${ }^{4}$. Section 4.3 concludes the chapter.

\subsection{The Impact of Audit Factors on the Level of Discretionary Accruals}

\subsubsection{The Relationship between Big 4, Audit firm's Office Location and Discretionary Accruals}

I begin the development of the hypotheses around which my empirical analysis is based by first noting that larger audit firms have greater incentives to detect and then report any material misstatements which may appear in an audit client's financial statements (DeAngelo 1981b; Becker et al. 1998). Here, DeAngelo (1981b) argues that larger audit firms have a bigger reputational capital to protect and therefore, have a greater incentive to guard against potential litigation risks. This in turn will mean that they will take a more conservative approach to financial reporting issues than will be the case with smaller audit firms. Furthermore, DeFond and Subramanyam (1998) hypothesise that larger audit firms will have a greater level of expertise and therefore, the resources necessary to provide a higher quality of audit for their clients.

Numerous empirical studies have used the theoretical models of DeAngelo (1981b) and DeFond and Subramanyam (1998) as the basis for empirical specifications

\footnotetext{
${ }^{4}$ Before conducting this research, I spoke with quite a number of chartered accountants who have worked as auditors with one or more of the Big 4 firms. In each instance, they informed me that by the time they completed their procedural and balance sheet audit processes they had a very good understanding of the extent to which the client firm had sought to manipulate the figures appearing in their financial statements.
} 
which investigate the relationship between the level of discretionary accruals (DACCs) and whether an audit client employs a Big 4 or a lower tier audit firm. For example, Krishnan (2003) employs U.S. data covering the period from 1989 until 1998 and finds that there is a greater level of significance between the stock returns and discretionary accruals of client firms who employ a Big 6 auditor when compared to client firms that employ a non-Big 6 auditor. Likewise, the discretionary accruals of clients of Big 6 auditors have a statistically more significant relationship with future profitability than the discretionary accruals of clients of non-Big 6 auditors. Similarly, using a sample of Singaporean firms covering the year 2003, Rusmin (2010) also finds a lower level of discretionary accruals amongst firms with a Big 4 auditor in comparison to firms with a Non-Big 4 auditor. Moreover, Francis and Wang (2008) use a cross-international sample of firms from 42 countries covering the period from 1994 until 2004 and report that there is a statistically significant association between the level of investor protection regulation, the use of Big 4 auditors and the level of discretionary accruals around the world. Given this, I now advance the following hypothesis:

\section{H1: Client firms which employ a Big 4 audit firm will have a lower level of DACCs than client firms which employ a non-Big 4 audit firm.}

Audit quality, as measured by the level of discretionary accruals, also differs across different local-based offices within a given audit firm (Francis and Yu 2009; Choi et al. 2010). Here, Choi et al. (2010) note that an audit engagement is administered and implemented by a partner and audit team at a local audit office and not by the national headquarters of the affected audit firm. They note that this will mean the audit decisions relating to a particular client firm are more often than not made at a local office level rather than by the national headquarters of the given audit firm (Francis 2004; Knechel et al. 2012). Thus the quality of a particular audit engagement needs to be assessed at the local audit office level. 
Here, it needs to be recalled (as in section 3.1.2) that the audit market in New Zealand is concentrated in the two major cities of Auckland and Wellington. For example, $77.3 \%(89 / 115)$ of the client firms on which the study by Knechel et al. (2012) is based involve audit firms whose principal office is located in either Auckland or Wellington. Similarly, $80 \%$ of the firm-years comprising the sample on which the empirical analysis summarised in this thesis is based, involve audit firms whose principal office is located in one these two major cities (as in section 6.1). The concentration of audit work in New Zealand in these two major cities brings some advantages in terms of audit quality. First, it means that the audit offices located in Auckland and Wellington will have a relatively larger number of audit clients when compared with other New Zealand towns and cities. Here, Choi et al. (2010) argue that audit offices which have a larger number of audit clients will have more audit experience and less incentives to compromise their independence. In particular, Choi et al. (2010) report empirical evidence which shows that audit office size (in term of the number of audit clients in each office) is significantly associated with audit quality (as measured by DACCs). Second, audit offices located in Auckland and Wellington will have greater opportunities to employ more competent and better qualified auditing professionals as well as the means to apply the latest technologies in their audit work (Hay and Jeter 2011). These advantages will more than likely enable audit offices in Auckland and Wellington to provide higher audit quality. Given this, I now advance the following hypothesis:

H2: Client firms which engage an office of an audit firm located in a big city (that is, either Auckland or Wellington) have a lower level of discretionary accruals than audit clients who engage an office of an audit firm located in a provincial town or city. 


\subsubsection{The Relationship between Audit Busy Season and Discretionary Accruals}

The busy audit season is an enduring issue for audit firms and their staff. This issue arises from the fact that in every year, audit firms experience a particular time when they have a relatively high number of audit engagements but limited resources and a very narrow time window with which to complete them. The busy audit season typically involves problems of stress and burnout for audit staff. In particular, Sweeney and Summers (2002) note that the busy audit season causes audit job burnout and this in turn can lead to a reduction in auditor commitment. Moreover, Johnson-Moreno (2003) argue that the busy audit season leads to auditor stress that in turn results in mental, emotional and physical issues that can affect the human biochemical and immune systems and thereby result in a reduced level of audit staff efficiency and performance.

Prior experimental research also indicates that workload pressures in the busy audit season will lead to potential degradation in auditor performance (Agoglia et al. 2010) and therefore lead to lower audit quality (Coram et al. 2004). For example, López and Peters (2012) report that the magnitude of abnormal accruals is higher if the audit is conducted during the busy audit season. Moreover, Jones III et al. (2010) summarise experimental results which also indicate that an auditor's healthy lifestyle and stress are significantly associated with their job outcomes. Given this, I now advance the following hypothesis:

H3: There is a positive relationship between the level of DACCs and the conduct of an audit engagement during the busy audit season. 


\subsubsection{The Relationship between Non-audit Fees and Discretionary Accruals}

Client firms purchase non-audit services in order to improve their operating performance and effectiveness (Antle et al. 2006). Furthermore, the purchase of non-audit services will invariably result in improvements in the client firm's system of internal control. These improvements in the system of internal control will in turn reduce management's capacity to use discretionary accruals to manipulate the firm's earnings. For example, suppose a client firm hires its auditor to review and/or install a debt internal control system. If the system is effective, these non-audit services will more than likely reduce the incidence of bad and doubtful debts and thereby lead to a reduction in the provisions which need to be made in this area. Given this, Antle et al. (2006), hypothesise that the level of nonaudit fees are negatively associated with the level of discretionary accruals.

The level of auditor independence can also have an impact on the relationship between audit fees, non-audit fees and discretionary accruals. In particular, an auditor will be either deliberately or unconsciously biased when faced with the possible loss of fee income associated with a given audit client (Ashbaugh et al. 2003; Frankel et al. 2002; Antle et al. 2006). For example, Antle et al. (2006) amongst others argue that auditors are less likely to object to management's accounting choices when they have concerns about losing the audit contract or the non-audit fee income associated with a given audit client. Therefore, the magnitude of both audit and non-audit fees are hypothesised to be positively associated with the level of discretionary accruals. Unfortunately, empirical tests of this hypothesis (as reviewed in section 2.2.6) have returned inconclusive and often, conflicting results. In particular, Mauldin (2003) shows that professional investors in the United States perceive auditor independence to be impaired when auditors provide non-audit services with a special focus on internal audit and merger and acquisition services. Moreover, Frankel et al. (2002) find that the ratio of non-audit fee income to total audit 
fees (which they take to be a measure of auditor independence) is significantly associated with the level of discretionary accruals. In contrast, Ashbaugh et al. (2003) find no systematic evidence supporting the claim that auditors violate their independence as a result of clients purchasing relatively more non-audit services. This result is supported by empirical evidence presented in Chung and Kallapur (2003) and Larcker and Richardson (2004) both of whom show that the provision of non-audit services does not appear to impair auditor independence.

Cahan et al. (2008) employ a sample of 237 firm-year observations of firms listed on the NZSX covering the period from 1995 until 2001. They find that the rate of growth in the non-audit fees received from a particular audit client is not associated with the level of discretionary accruals. Similarly, Knechel et al. (2012) employ a sample of 230 firm-year observations of firms listed on the NZSX and estimate discretionary accruals using the modified Jones (1991) model as developed by Kothari et al. (2005). They conclude that there is no evidence of a relationship between the level of auditor independence and the magnitude of the non-audit fees received by the auditor. These empirical results and particularly those of Knechel et al. (2012) and Cahan et al. (2008) prompt me to advance the following hypothesis relating to the relationship between the ratio of non-audit fees to total audit fees paid and the level of discretionary accruals in New Zealand:

H4: The ratio of non-audit fees to total audit fees paid is not associated with the level of discretionary accruals (that is, DACCs).

\subsubsection{The Relationship between Auditor Change and Discretionary Accruals}

Regulators view auditor changes with a great deal of suspicion because of the implication that they may be motivated by opportunistic behaviour arising out of a client firm's desire to appoint an auditor who will be willing to accept the 
accounting policies that will enable the client firm to achieve its financial reporting objectives (Francis and Wilson 1988; DeFond 1992). Here, DeFond and Subramanyam (1998) argue that auditors often prefer conservative accounting policies in order to protect themselves against future litigation and the potential damages which arise out of the discretionary accrual accounting policies invoked by client firms. However, the level of conservatism practised will vary between auditors due to the individual assessments of client risk and the relative risk propensities of each auditor. Hence, DeFond and Subramanyam (1998) hypothesise that there will be a greater potential for a client firm's management to replace an incumbent auditor when the incumbent audit firm is more conservative than the “average" audit firm.

However, Davidson III et al. (2006) argue that there is more than one reason why a client firm might want to remove an incumbent auditor and in particular, that there are many reasons why a change of auditor might be beneficial for a firm's stockholders. For example, Davidson III et al. (2006) argue that a firm might replace its incumbent auditor in order to improve the quality of the financial information it reports to its stockholders or even to improve its public image. Moreover, a firm also may change its incumbent auditor because of high audit costs or because the incumbent auditor is unwilling or unable to conduct the audit at the time of the year that the audit client wishes. Unfortunately, recent research that investigates these reasons for removing an incumbent auditor provides only mixed results. While DeFond and Subramanyam (1998) conclude that auditor changes are precipitated by the tensions which arise between client firms and their auditors about the level of discretionary accruals, (Davidson III et al. 2006) find that, on average, earnings management does not increase following auditor changes. Here Lee et al. (2003) extend the DeFond and Subramanyam (1998) study by employing a sample based on a longer time period but they were unable to replicate 
the original DeFond and Subramanyam (1998) findings over the extended period of time employed in their empirical analysis. Given this, I now advance the following hypothesis:

H5: Removing an incumbent auditor has no effect on the level of DACCs in the next ensuing reporting period.

\subsubsection{The Relationship between Audit Opinion and Discretionary Accruals}

Accruals-based earnings are supposed to provide more relevant information for users of financial statements than cash flows (Dechow et al. 1994; Subramanyam 1996; Francis and Krishnan 1999). Here, Francis and Krishnan (1999) argue that firms with a higher level of DACCs will be more likely to encounter going concern issues than firms with a lower level of DACCs. In particular, Francis and Krishnan (1999) note that accrual accounting policies recognise assets that often lead to a realization problem; for example, when to write-off uncollectible debtors' accounts or to write down book values because of asset impairment. Second, accrual accounting policies create a divergence between cash flows and reported earnings and this can also have an adverse impact on going concern assessments. Here Francis and Krishnan (1999) hypothesise that auditors will protect themselves against the risk exposure arising from going concern issues by lowering the threshold they apply for the issuance of a qualified (or conditional) audit opinion (Johl et al. 2007; Francis and Krishnan (1999)) and Bradshaw et al. (2002) use a large sample of U.S. publicly listed firms and find that there is a significant positive relationship between the level of discretionary accruals and the probability of an audit firm issuing a qualified (or conditional) audit opinion. Similarly, Johl et al. (2007) use Malaysian data covering the period from 1994 until 1999 and also conclude that Big 5 auditors in Malaysia appear to qualify their audit reports more 
frequently than their non-Big 5 counterparts when high levels of discretionary accruals are involved. Given this, I now advance the following hypothesis:

H6: There is positive relationship between the level of DACCs and the likelihood of receiving a qualified or conditional audit opinion.

\subsection{The Relationship between Discretionary Accruals and Audit Fees}

We begin this section by noting that higher levels of discretionary accruals (that is, DACCs) may require additional audit checks and procedures than would otherwise be the case and these will invariably lead to higher audit fees. In particular, discretionary accruals are an important instrument used by client firms in the manipulation of the earnings figures which appear on their financial statements (Jones 1991; Dechow et al. 1995; Dechow et al. 2010). Therefore, the higher the audit risk associated with a particular client firm (that is, the higher the level of DACCs) the more time and effort the audit firm is likely to devote to the audit of the client firm's financial statements. This in turn will more than likely lead to an increased level of audit fees (Fatima 2011; Gul et al. 2003).

Unfortunately, this argument is afflicted by at least two limitations. First, earnings management is an endogenous variable in most audit fee models (Antle et al. 2006). The detection of earnings management will on the one hand, increase audit effort. If, however, an auditor increases their audit effort, it is likely they will detect even more instances of earnings management. This in turn will reduce the earnings management risk associated with the client firm's audited financial statements. Thus, in a regression of audit fees on discretionary accruals, the level of the discretionary accruals will be correlated with the error term in the regression equation and this will lead to potentially biased estimates of parameter values. Furthermore, professional accounting bodies generally require that at the beginning 
of the fiscal year an audit firm and its audit client will negotiate a provisional audit fee (based on the estimated time required for the audit and the rate to be paid per hour to audit operatives) and they will both sign an engagement letter to that effect. After this the audit firm will base the final audit fee on the actual audit work required and their standard charge out rates (NZICA 2009; IFAC 2009; Hackenbrack et al. 2011). However, when Hackenbrack et al. (2011) interviewed audit partners from three of the Big 4 U.S audit firms they found that most audit fees are fixed fee contracts under which audit fees for additional services must be approved by the client firm's audit committee either in advance or negotiated on the basis of unusual transactions or events that require additional audit time and effort.

This observation is consistent with the New Zealand audit environment. In particular, section 197 of the New Zealand Companies Act, 1993 provides that the fees and expenses of an auditor shall normally be fixed by the client firm at the annual general meeting of the client firm. Here, Karen et al. (2011, p. 70) note that:

"[in New Zealand] although the auditor may return to the board should he/she find that ... [un] expected costs arise, the audit firm would be wise to calibrate its fees as carefully as possible at the time determined to avoid loss or conflict later".

This in turn means that the provisional audit fee or the fixed fee contract negotiated by the audit firm will of necessity be heavily influenced by the audit firm's expectation of the extent and magnitude of the client firm's earnings management practices. Hence, it is likely that the audit fee is more dependent on the audit firm's ex ante expectations about the client firm's earnings management practices than it is on the realised levels of the earnings management practices invoked by the client firm in the past - although the two are undoubtedly related. This argument is consistent with Bedard and Johnstone (2004) who investigate the impact of the 
audit firm's earnings management risk assessment on audit fee determination prior to the commencement of the audit engagement. Their findings suggest that the earnings management risk assessment made prior to the commencement of the audit engagement is significantly associated with the level of the audit fee charged by the audit firm. Consistent with Bedard and Johnstone (2004) my empirical analysis assumes that every year the auditor will review both the general and specific factors affecting their audit responsibilities in relation to a particular audit client. They will then determine what they consider to be an appropriate level of audit fee for the next ensuing year. Likewise, the senior management in conjunction the audit committee of the particular audit client will determine what they consider to be an appropriate audit fee for the next ensuing year. Then by a process of bargaining and gaming the audit client and audit firm will come to an agreement about the level of the audit fee to be paid in the next ensuing year. The gaming aspect of the negotiations will be based on the way the auditor has resolved the accounting and auditing issues that have arisen during the previous year's audit as well as the expressed intentions of the audit firm and desires of the audit client about the way the audit ought to be conducted and the audit and accounting issues resolved in the next ensuing year. Hence, the agreed audit fee for the next ensuing year is likely to reflect information about the level of earnings management in prior years and of how the issues arising out of these earnings management procedures have been resolved between the client firm and the audit firm. A tabular summary of the procedures which govern the determination audit fees is contained in Figure 4.1. The above considerations allow me to posit the following hypothesis:

H7: DACCs in the current year are positively associated with the level of next year's audit fee. 
Figure 4.1: The Relationship between Earnings Management and Audit Fees

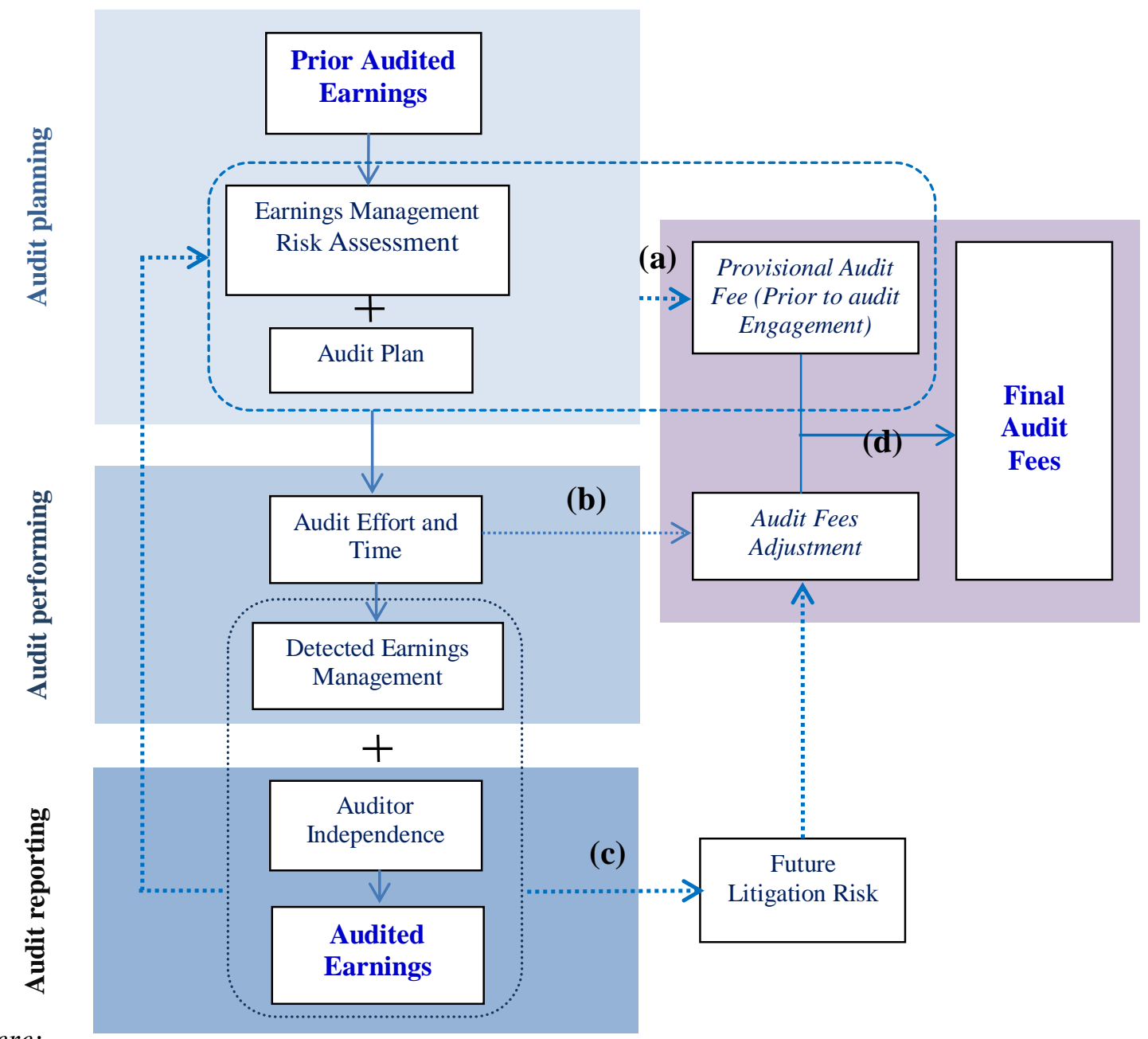

Where:

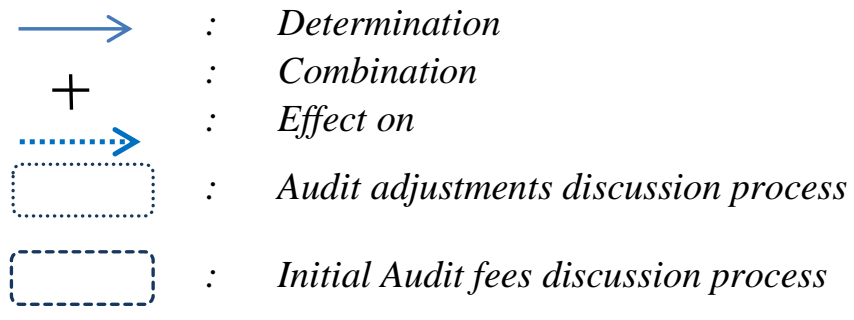

(a): Supported by Bedard and Johnstone (2004)

(b): Supported by Gul et al. (2003); Fatima (2011) and Schelleman and Knechel (2010)

(c): Supported by Abbott et al. (2006) and Schelleman and Knechel (2010)

(d): Supported by Hackenbrack et al. (2011). 


\subsection{Conclusion}

In this chapter I use the summary of the literature provided in chapter two of the thesis and the summary of the New Zealand research setting provided in chapter three to formulate hypotheses about the relationship between the audit factors identified in the literature and the level of DACCs which one would expect to find in a New Zealand context. In particular, I hypothesise that in a New Zealand context, the level of discretionary accruals will be lower for client firms which employ a Big 4 auditor; or engage an audit firm located in a big city (that is, either Auckland or Wellington); or has a fiscal year end which falls in the period from March to June. Moreover, I hypothesise that the level of DACCs is positively associated with the likelihood of receiving a qualified or conditional audit opinion. However, based on recent New Zealand empirical evidence and current New Zealand regulations relating to the change of auditors and the provision of non-audit services, I hypothesise that there is no relationship between auditor independence (as measured by auditor change and the ratio of non-audit services to total fees paid by a particular audit client) and the level of DACCs. In summary, the hypotheses developed in this chapter may be catalogued as follows:

H1: Client firms which employ a Big 4 audit firm will have a lower level of DACCs than client firms which employ a non-Big 4 audit firm.

H2: Client firms which engage an office of an audit firm located in a big city (that is, either Auckland or Wellington) have a lower level of discretionary accruals than audit clients who engage an office of an audit firm located in a provincial town or city. 
H3: There is a positive relationship between the level of DACCs and the conduct of an audit engagement during the busy audit season.

H4: The ratio of non-audit fees to total audit fees paid is not associated with the level of discretionary accruals (that is, DACCs).

H5: Removing an incumbent auditor has no effect on the level of DACCs in the next ensuing reporting period.

H6: There is positive relationship between the level of DACCs and the likelihood of receiving a qualified or conditional audit opinion.

In addition, this chapter develops an important hypothesis that relates the level of DACCs in the current year to the audit fees paid by client firms in subsequent years. Based on the methodological deficiencies and potential biases of prior research and the current regulations relating to the negotiation of audit fees in New Zealand, I hypothesise that the agreed audit fee for the next ensuing year is likely to reflect information about the level of earnings management in prior years and of how the issues arising out of these earnings management procedures have been resolved between the client firm and the audit firm. The particular hypothesis to be tested may be stated in the following terms:

H7: DACCs in the current year are positively associated with the level of next year's audit fee. 


\section{CHAPTER 5}

\section{DATA AND RESEARCH METHODOLOGY}

In this chapter, I describe the sample used and the research methodology employed in this thesis. Section 5.1 explains the procedures used for selecting the sample data employed in my empirical work. The sample is comprised of 567 firm-years listed on the New Zealand Stock Exchange and covers the period from 2006 until 2010. Moreover, in section 5.2 I describe the empirical procedures based on the modified Jones (1991) model that are used to estimate the level of discretionary accruals employed in my regression procedures. In section 5.3 two regression models are applied to my sample data. In particular, I employ the regression procedures previously invoked by Frankel et al. (2002), Antle et al. (2006) and Cahan et al. (2008) in order to examine the impact that the six audit factors alluded to in chapter 4 have on the level of DACCs. In addition to this, however, I employ the audit fee model of Simunic (1980) as refined by Choi et al. (2009), Francis and Simon (1987), Hay et al. (2006b) and Menon and Williams (2001) to test for the impact of the level of DACCs on the level of the audit fee in the next ensuring year. Section 5.4 concludes the chapter.

\subsection{Data Collection}

The data on which the empirical analysis summarised in the thesis is based is comprised of all 313 companies appearing on the New Zealand Stock Exchange database for at least part of the period from 1 January, 2004 until 31 December, 2010. In 2004, the New Zealand Security Commission published a voluntary code 
of corporate governance entitled "Corporate Governance in New Zealand: Principles and Guidelines". The code suggested that firms should disclose audit fees as well as a great deal of other audit information. Many firms elected to comply with the code and this in turn enabled me to collect the data I needed in order to implement my regression models. That is, before 2004 the data I needed to implement my regression models was not available in the public domain. This explains why my data covers the period from 2004 until 2010.

As noted in section 3.4, the New Zealand Stock Exchange has three main boards; namely, the main board or NZSX which is comprised of larger listed companies, the NZAX which is comprised of smaller and growing companies and the NZDX which is comprised of corporate and government bonds and other fixed interest securities. My empirical analysis excludes 60 firms that are listed only on the NZDX since I am unable to obtain share price data for these firms. ${ }^{5}$ This in turn will mean that for these firms I am unable to determine the ratio of the book value of equity to the market value of equity (that is, the book to market ratio) which is a key determining variable in my audit fee modelling procedures. I also exclude a further 75 firms which are not listed on the NZSX or NZAX for at least three consecutive years over the period from 1 January, 2004 until 31 December, 2010 since my modelling procedures require three continuous years of data ${ }^{6}$. There are also a further 35 firms for which financial and other data is not available for three consecutive years on the New Zealand Stock Exchange (that is, there is missing data) or whose financial statements are not denominated in the New Zealand

\footnotetext{
${ }^{5}$ See Appendix 1 for a detailed listing of the firms on which my empirical analysis is based.

${ }^{6}$ See Appendices 3, 4 and 5 for a detailed listing of these firms.
} 
dollar. ${ }^{7}$ My sample is thus comprised of $(313-60-75-35=) 143$ firms with at least three continuous years of complete data over the period from 1 January, 2004 until 31 December, 2010.

Of the 143 firms comprising my final sample, there are 92 firms which are listed on the NZSX or NZAX in all 7 years covering the period from 2004 until 2010; 12 firms which are listed on the NZSX or NZAX for 6 of the 7 years; 10 firms which are listed on the NZSX or NZAX for 5 of the 7 years; 17 firms which are listed in NZSX or NZAX for 4 years and finally, 12 firms which are listed on NZSX or NZAX for 3 years. This means that the sample on which my empirical procedures are based is comprised of 870 firm-years covering the period from 2004 until 2010 as summarised in Table 5.1.

Table 5.1: Number of Firm-years Collected in Sample

\begin{tabular}{|c|l|c|c|c|}
\hline No & \multicolumn{1}{|c|}{ Data } & Number & Years & Firm-years \\
\hline 1 & $\begin{array}{l}\text { Number of firms which have 7 years of data } \\
\text { (from 2004-2010) included in sample }\end{array}$ & 92 & 7 & 644 \\
\hline 2 & $\begin{array}{l}\text { Number of firms which have 6 years of data } \\
\text { (from 2004-2010) included in sample }\end{array}$ & 12 & 6 & 72 \\
\hline 3 & $\begin{array}{l}\text { Number of firms which have 5 years of data } \\
\text { (from 2004-2010) included in sample }\end{array}$ & 10 & 5 & 50 \\
\hline 4 & $\begin{array}{l}\text { Number of firms which have 4 years of data } \\
\text { (from 2004-2010) included in sample }\end{array}$ & 17 & 4 & 68 \\
\hline 5 & $\begin{array}{l}\text { Number of firms which have 3 years of data } \\
\text { (from 2004-2010) included in sample }\end{array}$ & 12 & 3 & 36 \\
\hline & Total & $\mathbf{1 4 3}$ & $\mathbf{8 7 0}$ \\
\hline
\end{tabular}

Here it will be recalled from section 2.1.4.4 above that my estimate of discretionary accruals is based on the modified Jones (1991) model (Dechow, 1995) and this

\footnotetext{
${ }^{7}$ See Appendices 6 and 7 for a detailed listing of these firms.
} 
requires data for two consecutive years in the estimation procedure. However, in 2004 there were 120 instances where consecutive firm-years of data were not available and so the modified Jones (1991) model could not be applied to these data. There were also 27 firm-years of missing data. Thus, in my thesis I used the full data set of $(870-120-27=) 723$ firm-years from 2005 until 2010 to estimate DACCs using the modified-Jones (1991) model $^{8}$.

Similarly, 125 firm-years of data for the year 2005 are also excluded because my audit fee model (as summarised in section 5.3.1) is based on the use of lagged DACCs. Finally, there are 31 firm-years of missing data. This means that the final sample on which my empirical analysis is based is comprised of (723 - $125-31=)$ 567 firm-years of data.

The data for each firm-year are collected from three sources. First, there is basic information like the firm name, its listing code on the New Zealand Stock Exchange, the currency employed in its financial statements, its balance sheet date and so on which are collected from New Zealand Stock Exchange website (https://www.nzx.com). Second, there is the financial information required in my modelling procedures (e.g. total assets; property, plant and equipment; gross revenues; receivables, etc.) which are provided by the New Zealand Stock

\footnotetext{
${ }^{8}$ This means that my estimation of the DACCs was a "one-shot" exercise based on the entire sample of data covering the period from 2005 until 2010. By using the full sample of data across all years from 2004 to 2010 I get a far more accurate estimate of the true DACCs and this helps to mitigate econometric problems associated with stochastic regressors, amongst other issues. The Dimson (1979) technique for ameliorating the effects of stochastic regressors due to thin trading employs a very similar procedure to the one I use here for estimating DACCs.
} 
Exchange database in a standard form Excel file. Third, the information relating to the firm's auditor (e.g. auditor name, audit fees paid, non-audit fees paid, audit opinion, auditor's principal office, etc.) were hand-collected from company annual reports which were downloaded from the New Zealand Stock Exchange company research website (http://companyresearch.nzx.com).

I would emphasise here that all of my data was collected by hand and subjected to extensive cross checking. Given this there are no issues with coding errors and therefore, there can be no issues with outliers. Here it is worth noting that the popular method of "winsorising" in which one drops or edits the tails of a given data set, is an inappropriate way of dealing with what is generally regarded as extreme data. Extreme data are actually an integral part of the data set and are to be anticipated rather than simply eliminated from my empirical analysis (Feynman 1992, p. 342; Ashton et al. 2004, p. 598).

Moreover, some years have hardly any observations for some of the variables. For example, only $4 \%$ of the firm-years comprising my sample involved a change of auditor; indeed, in 2010 there was only one instance of a client firm changing its auditor. This provides a further reason why my regression models were estimated as a "one-shot" exercise based on the entire sample of data covering the period from 2006 until 2010 rather than being estimated on a yearly basis using only data for the independent variables relating to that year. In some years there were simply not enough observations of the independent variables to provide the degrees of freedom necessary to ensure reliable results from our regression procedures.

\subsection{The Measurement of Discretionary Accruals}

I use discretionary accruals (DACC) as a proxy for earnings management. Here, the prior literature argues that both negative and positive DACCs can reflect a high level of earnings management. For example, if a firm pays its telephone bill in 
advance then it would be necessary to debit prepaid telephone expense (an asset which appears on the balance sheet) and credit the profit and loss account in order to reflect the prepayment. This would have the effect of reducing expenses and increasing the firm's earnings. In contrast, if a firm pays its telephone bill in arrears then it would be necessary to debit the profit and loss account and credit accrued telephone expense (a liability which appears on the balance sheet). This would have the effect of increasing expenses and decreasing the firm's earnings. In other words, large negative accruals (for example, prepaid telephone expense) can be used to conceal poor performance by inflating current earnings whilst large positive accruals (for example, accrued telephone expense) can be used to conceal poor future performance by reducing current earnings in order to artificially inflate future earnings (DeFond and Park 1997; Gul et al. 2003). Thus, in my empirical work I use the absolute value of the DACCs as a proxy for earnings management.

I estimate DACC for each sample firm by first using the modified Jones (1991) model as developed by Dechow et al. (1995). Under this model DACCs are estimated by a two-step procedure. First, total accruals (TAC) are calculated as:

$$
\operatorname{TAC}_{\mathbf{j t}}=\left(\Delta \mathrm{CA}_{\mathbf{j t}}-\Delta \mathrm{Cash}_{\mathbf{j t}}\right)-\left(\Delta \mathrm{CL}_{\mathbf{j t}}-\Delta \mathrm{STD}_{\mathbf{j t}}\right)-\mathrm{DPA}_{\mathbf{j t}}
$$

where:

$\mathrm{TAC}_{\mathrm{jt}}=$ total accruals for the $\mathrm{j}^{\text {th }}$ firm in period $\mathrm{t}$;

$\Delta \mathrm{CA}_{\mathrm{jt}}=$ change in current assets for the $\mathrm{j}^{\text {th }}$ firm from year $(\mathrm{t}-1)$ to $\mathrm{t}$;

$\Delta$ Cash $_{\mathrm{jt}}=$ change in cash balance for the $\mathrm{j}^{\text {th }}$ firm from year $(\mathrm{t}-1)$ to $\mathrm{t}$;

$\Delta \mathrm{CL}_{\mathrm{jt}}=$ change in current liabilities for the $\mathrm{j}^{\text {th }}$ firm from year $(\mathrm{t}-1)$ to $\mathrm{t}$;

$\Delta \mathrm{STD}_{\mathrm{jt}}=$ change in short-term debt for the $\mathrm{j}^{\text {th }}$ firm from year $(\mathrm{t}-1)$ to $\mathrm{t}$;

DPA $_{\mathrm{jt}}=$ depreciation and amortization expense for the $\mathrm{j}^{\text {th }}$ firm from year $(\mathrm{t}-1)$ to $\mathrm{t}$. 
The TAC is then decomposed into normal accruals (NAC) and discretionary accruals (DACC) using the modified Jones (1991) model which is defined formally as follows:

$$
\frac{T A C_{j, t}}{T A_{j, t-1}}=\propto_{1, j}\left(\frac{1}{T A_{j, t-1}}\right)+\propto_{2, j}\left(\frac{\Delta R E V_{j, t}-\Delta R E C_{j, t}}{T A_{j, t-1}}\right)+\propto_{3, j}\left(\frac{P P E_{j, t}}{T A_{j, t-1}}\right)+\varepsilon_{j, t}
$$

where:

$$
\begin{aligned}
& \mathrm{TAC}_{\mathrm{j}, \mathrm{t}}=\text { total accruals for the } \mathrm{j}^{\text {th }} \text { firm in year } \mathrm{t} ; \\
& \mathrm{TA}_{\mathrm{j}, \mathrm{t}-1}=\text { is total assets for the } \mathrm{j}^{\text {th }} \text { firm at the end of year }(\mathrm{t}-1) ; \\
& \Delta \mathrm{REV}_{\mathrm{j}, \mathrm{t}}=\text { change in net revenue for the } \mathrm{j}^{\text {th }} \text { firm between years }(\mathrm{t}-1) \text { and } \mathrm{t} ; \\
& \Delta \mathrm{REC}_{\mathrm{j}, \mathrm{t}}=\text { change in receivables for the } \mathrm{j}^{\text {th }} \text { firm between years }(\mathrm{t}-1) \text { and } \mathrm{t} .
\end{aligned}
$$

Normal accruals (NAC) are defined by the fitted value from equation (5.2) whilst discretionary accruals are captured by the residual term, $e_{j t}$, in this equation. I define the corresponding absolute value of discretionary accruals for firm $\mathrm{j}$ in year $\mathrm{t}$ as $\mathrm{DACC}_{\mathrm{jt}}$.

\subsection{Empirical Regressions}

My research is based on the prior literature in this area which has traditionally modelled all relationships in terms of linear functions. In particular, all my empirical analysis is based on variants of the two benchmark linear models of Simunic (1980) and Frankel et al. (2002) which underscore virtually every empirical study that has been undertaken in this area of the literature. 


\subsubsection{Audit Fee Model}

In order to test the hypotheses on which my empirical analysis is based, I employ the audit fee model of Simunic (1980) as refined by Choi et al. (2009), Francis and Simon (1987), Hay et al. (2006b) and Menon and Williams (2001). This model is underpinned by the following regression equation:

$$
\begin{aligned}
& \mathrm{LNAF}_{\mathrm{jt}}=\alpha_{0}+\alpha_{1} \mathrm{DACC}_{\mathrm{jt}-1}+\alpha_{2} \mathrm{LNTA}_{\mathrm{jt}}+\alpha_{3} \mathrm{INVREC}_{\mathrm{jt}}+\alpha_{4} \mathrm{SUB}_{\mathrm{jt}}+ \\
& \alpha_{5} \text {FOREIGN }_{\mathrm{jt}}+\alpha_{6} \mathrm{CREV}_{\mathrm{jt}}+\alpha_{7} \mathrm{LEVE}_{\mathrm{jt}}+\alpha_{8} \mathrm{LIQID}_{\mathrm{jt}}+\alpha_{9} \mathrm{BIG}_{\mathrm{jt}}+ \\
& \alpha_{10} \text {AOFFICE }_{j t}+\alpha_{11} \text { FISCAL }_{j t}+\alpha_{12} C_{-} \text {AUDITOR }_{j t}+\alpha_{13} \mathrm{AO}_{\mathrm{jt}}+ \\
& \alpha_{14} \mathrm{BTM}_{\mathrm{jt}}+\alpha_{15} \text { VOL_FRS }_{\mathrm{j}}+\alpha_{16} \mathrm{EMI}_{\mathrm{jt}}+\varepsilon_{\mathrm{jt}}
\end{aligned}
$$

where:

$\mathrm{LNAF}_{\mathrm{jt}} \quad=$ natural logarithm of the actual fee paid by the $\mathrm{j}^{\text {th }}$ firm in year $\mathrm{t}$ to its auditors for the audit of the firm's annual financial statements (that is, excluding fees for non-audit services).

$\mathrm{DACC}_{\mathrm{jt}-1}=$ absolute value of discretionary accruals for the $\mathrm{j}^{\text {th }}$ firm in year t-1 as calculated using the modified Jones (1991) model as described in Section 5.2.

LNTA $_{\mathrm{jt}}=$ natural logarithm of the total assets for the $\mathrm{j}^{\text {th }}$ firm at the end of year $\mathrm{t}$.

INVREC $_{\mathrm{jt}}=$ inventory and receivables divided by total assets of the $\mathrm{j}^{\text {th }}$ firm at the end of year $t$.

$\mathrm{SUB}_{\mathrm{jt}}=$ square root of the number of subsidiaries for the $\mathrm{j}^{\text {th }}$ firm at the end of year $t$.

FOREIGN $_{\mathrm{jt}}=$ square root of the number of overseas subsidiaries for the $\mathrm{j}^{\text {th }}$ firm at the end of year t. 
CREVjt $=$ Change in revenue for the $\mathrm{j}^{\text {th }}$ firm between year $(\mathrm{t}-1)$ and year $\mathrm{t}$.

LEVE $_{\mathrm{jt}} \quad=$ leverage defined as the $\mathrm{j}^{\text {th }}$ firm's total liabilities divided by total assets at the end of year $\mathrm{t}$.

LIQID $_{\mathrm{jt}}=$ current assets divided by current liabilities for the $\mathrm{j}^{\text {th }}$ firm at the end of year $t$.

$\mathrm{BIG}_{\mathrm{jt}}=1$ if the $\mathrm{j}^{\mathrm{th}}$ firm's auditor is from the Big4 during year $\mathrm{t}$ and 0 otherwise.

AOFFICE $_{\mathrm{jt}}=1$ if the $\mathrm{j}^{\text {th }}$ firm's auditor has its main office located in Wellington or Auckland in year $\mathrm{t}$ and 0 otherwise.

FISCAL $_{\mathrm{jt}}=1$ if firm $\mathrm{j}$ has a fiscal year ending between 31 March and 30 June in year $t$ and 0 otherwise;

C_AUDITOR $\mathrm{jt}_{\mathrm{t}}=1$ if the $\mathrm{j}^{\text {th }}$ firm changes its audit firm in year $\mathrm{t}$ and 0 otherwise.

$\mathrm{AO}_{\mathrm{jt}}=1$ if the $\mathrm{j}^{\text {th }}$ firm received a qualified or conditional audit opinion in year $\mathrm{t}$ and 0 otherwise.

BTM $_{\mathrm{jt}}=\mathrm{j}^{\text {th }}$ firm's book-to-market ratio for equity at the end of year t.

VOL_IFRS $S_{j}=1$ if the $j^{\text {th }}$ firm has voluntarily adopt IFRS over the period from 2005 until 2007 and 0 otherwise.

EMI $_{\mathrm{jt}} \quad=1$ if the $\mathrm{j}^{\text {th }}$ firm either buys back or issues new stock in year $\mathrm{t}$ and 0 otherwise;

$\varepsilon_{\text {it }}=$ stochastic error term for the $\mathrm{j}^{\text {th }}$ firm during year $\mathrm{t}$. 
The control variables are selected based on prior studies in this area. Consistent with Simunic (1980), Antle et al. (2006) and Hay et al. (2006a) among others I include total assets (LNTA) as a control variable in order to capture the influence of audit client size on the level of audit fees paid.

I also control for the busy audit season which in New Zealand, occurs over the period from 31 March until 30 June of each year. Here, Walker and Hay (2013) show that $74 \%$ of audit client balance sheet dates occur over this period. Thus, I use a dummy variable, FISCAL, to control for the busy audit season. FISCAL assumes a value of 1 if the client firm has a fiscal year ended between 31 March and 30 June, and 0 otherwise. Consistent with Hay and Jeter (2011) and Antle et al. (2006) I expect a positive relationship between FISCAL and LNAF.

I also control for the audit risk that arises from highly leveraged audit clients by including LEVE and LIQID as control variables in the audit fee model (e.g. Gist 1994; Hay et al. 2006b). Hay et al. (2006, p. 170) also argue that "the worse the performance of the organization, the more risk to the auditor and the higher the audit fee is expected to be." Given this, I include the CREV and BTM variables in the audit fee model in order to control for the increased audit fees that are likely to arise as a result of the more intensive audit procedures that will have to be implemented because of this. Hence, I include the CREV and BTM variables in the audit fee model in order to control for the increased audit fees that are likely to arise as a result of the more intensive audit procedures that will have to be implemented because of this.

Audit opinion (AO) is also included in my audit fee model to control for extreme audit risk. I define the dummy variable $\mathrm{AO}$ to be equal to 1 if the client firm receives a qualified or conditional audit opinion and 0 otherwise. 
Moreover, I also include the level of inventory and receivables (INVREC) as a control variable because they are frequently cited as a proxy for inherent audit risk (Simunic 1980; Griffin et al. 2009). Hay et al. (2006b), for example, argue that higher levels of inventory and receivables significantly increase the probability of material errors in a client firm's financial statements and that because of this, the audit will require more intensive and specialized audit procedures. Given this, I hypothesise that the level of inventory and receivables will be positively associated with the level of audit fees.

I also include the number of subsidiaries (SUB) and the number of foreign subsidiaries (FOREIGN) as control variables in order to reflect the client firm's organisational complexity. Prior research suggests that the more complex a client firm's financial arrangements, the more time and effort the auditor is likely to have to devote to the audit. Therefore, I expect that the total number of subsidiaries and in particular, the number of foreign subsidiaries, will have a positive association with the level of audit fees (Simunic 1980; Hay et al. 2006b).

I include BIG4 and AOFFICE as dummy control variables because prior research typically finds an audit premium when the auditor is one of the Big 4 audit firms and/or where the auditor's principal office is located in a capital or major provincial city (Choi et al. 2010). Moreover, I include C_AUDITOR as a dummy control variable in order to capture any "low-balling" effects; that is, the possibility that the auditor will reduce their initial engagement audit fee below cost in order to secure the audit (DeAngelo 1981a).

I also include EMI in the model to control for the impact of the inherent risk that arises from a client firm's activities of either buying back or issuing new stock through the New Zealand Stock Exchange. Finally, I also control for the impact that voluntary adoption of IFRS's might have on the magnitude of audit fees paid 
due to the fact that firms listed on the NZSX could voluntarily adopt IFRS reporting standards on or after 1 January 2005. Compulsory adoption of IFRS reporting standards in New Zealand only came into force for all NZSX listed firms on 1 January 2007.

\subsubsection{Discretionary Accruals Model}

The discretionary accruals equation employed in the empirical regressions is based on the models developed and used by Frankel et al. (2002), Antle et al. (2006) and Cahan et al. (2008). These models are all based on variants of the following regression specification:

$$
\begin{aligned}
& \text { DACC }_{j t}=\alpha_{0}+\left[\alpha_{11} \text { BIG4 }_{j t}+\alpha_{12} \text { AOFFICE }_{j t}+\alpha_{13} \text { FISCAL }_{j t}+\right. \\
& \left.\alpha_{14} C_{-} \text {AUDITOR }{ }_{\mathrm{jt}}+\alpha_{15} \mathrm{AO}_{\mathrm{jt}}+\alpha_{16} \mathrm{RNAF}_{\mathrm{jt}}\right]+\alpha_{2} \mathrm{EMI}_{\mathrm{jt}}+ \\
& \alpha_{3} \mathrm{CFO}_{\mathrm{jt}}+\alpha_{4} \mathrm{LEVE}_{\mathrm{jt}}+\alpha_{5} \mathrm{LIQID}_{\mathrm{jt}}+\alpha_{6} \mathrm{LOSS}_{\mathrm{jt}}+\alpha_{7} \mathrm{INVREC}_{\mathrm{jt}}+ \\
& \alpha_{8} \text { BTM }_{j t}+\alpha_{9} \text { SUB }_{j t}+\alpha_{10} \text { FOREIGN }_{j t}+\alpha_{11} \text { CREV }_{j t}+ \\
& \alpha_{12} \text { VOL_IFRS }{ }_{j t}+\alpha_{13} L_{N T A C C}+\varepsilon_{j t}
\end{aligned}
$$

where:

DACC $_{\mathrm{jt}} \quad=$ absolute value of discretionary accruals for the $\mathrm{j}^{\text {th }}$ firm in year $t$ as calculated by the modified Jones (1991) model (as in Section 5.2).

Testing variables:

$\mathrm{BIG}_{\mathrm{jt}}=1$ if the $\mathrm{j}^{\text {th }}$ firm employs a Big4 audit firm during year $\mathrm{t}$ and 0 otherwise.

AOFFICE $_{j t}=1$ if the $j^{\text {th }}$ firm's auditor has its main office located in Wellington or Auckland in year $\mathrm{t}$ and 0 otherwise.

FISCAL $_{\mathrm{jt}}=1$ if the $\mathrm{j}^{\text {th }}$ firm has a fiscal year ending between 31 March and 30 June in year $t$ and 0 otherwise; 
C_AUDITOR $\mathrm{jt}_{\mathrm{t}}=1$ if the $\mathrm{j}^{\text {th }}$ firm changes its audit firm in year $\mathrm{t}$ and 0 otherwise.

$\mathrm{AO}_{\mathrm{jt}} \quad=1$ if the $\mathrm{j}^{\text {th }}$ firm received a qualified or conditional audit opinion in year $\mathrm{t}$ and 0 otherwise.

$\mathrm{RNAF}_{\mathrm{jt}}=$ ratio of non-audit fees to total fees paid by firm $\mathrm{j}$ in year $\mathrm{t}$.

\section{Control variables:}

EMI $_{\mathrm{jt}} \quad=1$ if the $\mathrm{j}^{\text {th }}$ firm either buys back or issues new stock in year $\mathrm{t}$ and 0 otherwise;

$\mathrm{CFO}_{\mathrm{jt}}=$ Operating cash flows, scaled by beginning of period total assets for the $\mathrm{j}^{\text {th }}$ firm at the end of year $\mathrm{t}$.

LEVE $_{\mathrm{jt}} \quad=$ the $\mathrm{j}^{\text {th }}$ firm's leverage (as measured by total liabilities divided by total assets at the end of year $t$ ).

LIQID $_{\mathrm{jt}}=$ current assets divided by current liabilities for the $\mathrm{j}^{\text {th }}$ firm at the end of year $t$.

LOSS $_{\mathrm{jt}}=1$ if the $\mathrm{j}^{\text {th }}$ firm reported a loss during year $\mathrm{t}$ and 0 otherwise.

INVREC $_{\mathrm{jt}}=$ inventory and receivables divided by total assets of the $\mathrm{j}^{\text {th }}$ firm at the end of year $t$.

$\mathrm{BTM}_{\mathrm{jt}}=\mathrm{j}^{\text {th }}$ firm's book-to-market ratio for equity at the end of year $\mathrm{t}$.

$\mathrm{SUB}_{\mathrm{jt}} \quad=$ natural logarithm of 1 plus the number of subsidiaries for the $\mathrm{j}^{\text {th }}$ firm at the end of year $\mathrm{t}$.

FOREIGN $_{\mathrm{jt}}=$ natural logarithm of 1 plus the number of overseas subsidiaries for the $\mathrm{j}^{\text {th }}$ firm at the end of year $\mathrm{t}$.

$\mathrm{CREV}_{\mathrm{jt}} \quad=$ Change in revenue for the $\mathrm{j}^{\text {th }}$ firm between year $(\mathrm{t}-1)$ and year $\mathrm{t}$.

VOL_IFRS $S_{j t}=1$ if the $j^{\text {th }}$ firm has voluntarily adopt IFRS over the period from 2005 until 2007 and 0 otherwise.

LNTACC $_{\mathrm{jt}}=$ Total accruals for the $\mathrm{j}^{\text {th }}$ firm at the end of year $\mathrm{t}$.

$\varepsilon_{\mathrm{jt}}=$ stochastic error term for the $\mathrm{j}^{\text {th }}$ firm during year $\mathrm{t}$. 
The control variables are selected based on prior studies in this area. First, Frankel et al. (2002) and Cahan et al. (2008) amongst others argue that the modified Jones (1991) model might not remove the impact of non-discretionary accruals that are related to firm performance. We, therefore, follow Frankel et al. (2002) and Cahan et al. (2008) by including cash flow from operations (CFO), total accruals (LNTACC), the book to market ratio (BTM) and the change in revenue (CREV) as control variables for the level of firm performance. I also control for the financial distress that might arise for highly leveraged audit clients and/or client firms with a history of losses on their income statements by including the LEVE, LIQID and LOSS variables as controls in my discretionary accruals regression specification. Here, Frankel et al. (2002) and Cahan et al. (2008) note that client firms tend to have higher levels of DACCs when they are afflicted with problems of financial distress. Moreover, I also include the level of inventory and receivables (INVREC) as a control variable because higher levels of inventory and receivables significantly increase the probability of material errors in a client firm's financial statements and therefore they may be highly correlated with the level of DACCs (Hay et al. 2006b).

As in Knechel and Sharma (2012) and other studies, I include the number of subsidiaries (SUB) and the number of foreign subsidiaries (FOREIGN) as control variables in order to reflect the client firm's size and organisational complexity. Previous research shows that large and complex firms (as measured by the number of their subsidiaries) tend to have less stable and predictable operations and hence, may have a higher level of DACCs (Dechow and Dichev 2002).

We also include the EMI variable in the model to control for the earnings manipulation incentives that client firms have when they are about to issue new stock or buy pre-existing stock back through the New Zealand Stock Exchange. Finally, I also control for the impact that voluntary adoption of IFRS's might have on the level 
DACCs due to the fact that firms listed on the NZSX could voluntarily adopt IFRS reporting standards on or after 1 January 2005. Compulsory adoption of IFRS reporting standards in New Zealand only came into force for all NZSX listed firms on 1 January 2007.

\subsection{Conclusion}

Chapter five has described the database and research methodology employed in this thesis. My initial sample consists of 313 companies appearing on the New Zealand Stock Exchange database for at least part of the period from 1 January, 2004 until 31 December, 2010. I exclude firms that are listed only on the NZDX as well as firms whose financial and other data is not available for three consecutive years on the New Zealand Stock Exchange database. I further exclude all client firms whose auditors are not located in New Zealand or whose financial statements are not denominated in the New Zealand dollar. This means that the sample on which my regression procedures are based is comprised of $\mathrm{N}=567$ firm-years covering the period from 2006 until 2010.

Section 5.2 then provides a detailed description of the modified Jones (1991) model which is the principal model used to estimate the discretionary accruals on which the empirical analysis in this thesis is based. In section 5.3 two regression models are applied to my sample data. I employ the regression procedures previously invoked by Frankel et al. (2002), Antle et al. (2006) and Cahan et al. (2008) in order to examine the impact that six audit factors (BIG4, AOFFICE, AO, FISCAL, RNAF and C_AUDITOR) have on the level of DACCs. In addition to this, however, I employ the audit fee model of Simunic (1980) as refined by Choi et al. (2009), Francis and Simon (1987), Hay et al. (2006b) and Menon and Williams (2001) to test for the impact that the level of discretionary accruals in the current year can have on the level of the audit fee in next ensuring year. 


\section{CHAPTER 6 EMPIRICAL RESULTS}

In chapter six, I summarise the important results obtained in the empirical work on which this thesis is based. Thus, section 6.1 starts with summary descriptive statistics for the sample used in the empirical work. Section 6.2 provides a summary of the empirical results obtained for the Frankel et al. (2002), Antle et al. (2006) and Cahan et al. (2008) model which deals with the impact that the BIG4, AOFFICE, AO, FISCAL, RNAF and C_AUDITOR audit factors have on the level of DACCs. This section also summarises the empirical results obtained for the Simunic (1980) audit fee model which tests for the impact that the level of DACCs in the current year have on the level of the audit fee in next ensuring year. Sections 6.3 summarises several robustness and sensitivity tests relating to the empirical procedures employed in this chapter. Section 6.4 concludes the chapter.

\subsection{Descriptive Statistics}

Table 6.1 summarises the time series properties of the audit fees, non-audit fees paid and of their relationship to the total assets employed by the New Zealand firms comprising my sample. I begin by noting that the average annual fee paid for audit services relating to the preparation of a firm's statutory financial statements over the period from 2006 to 2010 is $\$ N Z 253,100$. The average audit fee increased significantly from $\$ 229,100$ in 2005 to $\$ 273,970$ in 2009 before declining slightly to $\$ 263,790$ in 2010 . Similarly, firm size in terms of the average book value of total assets employed also increased considerably from around $\$ 463$ million in 2006 to $\$ 617$ million in 2008. Beyond this point, however, average total assets decreased slightly to $\$ 602$ million in 2009 and $\$ 586$ million in 2010. These figures mean that the ratio of average audit fees to the average book value of total assets employed by 
the firm-years comprising my sample is relatively stable over the period of my empirical analysis, varying from a low of $0.043 \%$ in 2008 to a high of $0.049 \%$ in 2006. In contrast, average non-audit fees are highly volatile over the period from 2006 to 2010. Thus, average non-audit fees decreased from \$96,000 in 2006 to $\$ 92,630$ in 2007 before reaching a peak of $\$ 114,000$ in 2008 . However, average non-audit fees then decreased steadily to $\$ 111,600$ in 2009 and \$92,460 in 2010.

Table 6.1: Average Auditfees, Average Non-audit fees and Average Total Assets across the $N=567$ Firm-years Covering the Period from 2006 until 2010

\begin{tabular}{|c|c|r|r|r|r|r|r|c|}
\hline Year & $\begin{array}{c}\text { Number } \\
\text { of firms }\end{array}$ & $\begin{array}{c}\text { Average } \\
\text { Audit Fees } \\
\text { (AF) } \\
\mathbf{1 , 0 0 0 \$ N Z}\end{array}$ & $\begin{array}{c}\text { Average } \\
\text { Non-Audit } \\
\text { Fees (NAF) } \\
\mathbf{1 , 0 0 0 \$ N Z}\end{array}$ & $\begin{array}{c}\text { Average } \\
\text { Total fees } \\
\text { (TAF) } \\
\mathbf{1 , 0 0 0 \$ N Z}\end{array}$ & $\begin{array}{c}\text { Average } \\
\text { Total Assets } \\
\text { (TA) } \\
\mathbf{1 , 0 0 0}\end{array}$ & AF/TA & NAF/TA & $\begin{array}{c}\text { NAF/ } \\
\text { TAF }\end{array}$ \\
\hline 2006 & 112 & 229.10 & 96.00 & 325.09 & $463,006.20$ & $0.049 \%$ & $0.021 \%$ & $30 \%$ \\
\hline 2007 & 115 & 235.75 & 92.63 & 328.38 & $534,787.10$ & $0.044 \%$ & $0.017 \%$ & $28 \%$ \\
\hline 2008 & 112 & 262.77 & 114.18 & 376.95 & $617,504.90$ & $0.043 \%$ & $0.018 \%$ & $30 \%$ \\
\hline 2009 & 114 & 273.97 & 111.60 & 385.57 & $602,729.80$ & $0.045 \%$ & $0.019 \%$ & $29 \%$ \\
\hline 2010 & 114 & 263.79 & 92.46 & 356.26 & $586,543.80$ & $0.045 \%$ & $0.016 \%$ & $26 \%$ \\
\hline $\begin{array}{c}\text { Average } \\
\text { across all } \\
\text { firm-years }\end{array}$ & $\mathbf{5 6 7}$ & $\mathbf{2 5 3 . 1 0}$ & $\mathbf{1 0 1 . 3 3}$ & $\mathbf{3 5 4 . 4 3}$ & $\mathbf{5 6 1 , 0 1 4 . 0 0}$ & $\mathbf{0 . 0 4 5 \%}$ & $\mathbf{0 . 0 1 8 \%}$ & $\mathbf{2 9 \%}$ \\
\hline
\end{tabular}

Table 6.2 provides basic descriptive statistics for all the variables employed in my empirical analysis. Thus, the BIG4 variable indicates that about $81 \%$ of the firmyears comprising my sample involve an audit by one of the Big 4 audit firms. Here it is also interesting to note that the AOFFICE variable shows that about $80 \%$ of the firm-years comprising my sample are made up of audit firms whose principal offices are located in either Auckland or Wellington. Taken together, these latter two statistics show that the audit market in New Zealand is highly concentrated. Moreover, the FISCAL variable indicates that $77 \%$ of the New Zealand listed firms comprising my sample have a fiscal year end that falls into the busy audit season in New Zealand which lasts from 31 March to 30 June. The AO variable indicates that 
about $14 \%$ of the listed firms included in my sample received a qualified or modified audit opinion during the period from 2006 to 2010. Moreover, the C_AUDITOR variable shows that only $4 \%$ of the firm-years comprising my sample involve a change of auditor.

Table 6.2 also shows that the listed firms included in my sample have average total assets (TA) of $\$ 561,014,000$. The standard deviation of the total assets across the $\mathrm{N}=567$ firm-years comprising my sample is $\$ 1,206,298,000$. The minimum of the TA measures across the $\mathrm{N}=567$ firm-years comprising my sample is $\$ 113,000$ whilst the maximum measure is $\$ 8,276,000,000$. Moreover, I summed the inventory and accounts receivable for each firm in my sample and divided it by the total assets for the given firm. The average of this ratio across the $\mathrm{N}=567$ firm-years comprising my sample amounted to 0.24 and is recorded in the INVREC row of Table 6.2. The standard deviation of the INVREC measures across the $\mathrm{N}=567$ firmyears comprising my sample is 0.21 whilst the minimum INVREC measure is close to zero and the maximum INVREC measure is 0.88. The SUB and FOREIGN variables in Table 6.2 show that on average each firm-year comprising my sample has 2.55 subsidiaries of which an average of 1.01 are foreign subsidiaries. Next, the LEVE and LIQID variables indicate that the average leverage and average quick assets ratio of the firms included in my sample are 0.51 and 3.67, respectively. Moreover, the LOSS variable indicates that $32 \%$ of the firm-years comprising my sample involve firms that have reported a loss in their statutory financial statements. The variables CREV, BTM and CFO indicate that the average continuously compounded proportionate increase in sales amounts to $5.02 \%$ per annum, the average book to market ratio is 8.31 and the average operating cash flow amounts to $\$ 47,379,000$ per annum. The VOL_IFRS variable indicates that $36 \%$ of the listed firm-years comprising my sample voluntarily adopted IFRS standards before the compulsory adoption date of 1 January 2007. Also, EMI indicates that in $16 \%$ of the 
firm-years comprising my sample the affected firm either issues new stock on the New Zealand Stock Exchange (e.g., a rights issue of new shares) or is involved in a stock buyback. Finally, Table 6.2 shows that the mean measure for the absolute value of discretionary accruals (DACC) is $\$ 36,697,000$. Here it will be recalled that the DACC measures are determined using the modified Jones (1991) model developed by Dechow et al. (1995) as summarised in section 5.2. ${ }^{9}$

Table 6.2: Descriptive Statistics of Audit Factors and Control Variables Employed across the $N=567$ firm-years covering the Period from 2006 until 2010

\begin{tabular}{|c|c|c|c|c|c|}
\hline Variable & Obs & Mean & Std. Dev. & Min & Max \\
\hline $\mathrm{AF}$ & 567 & 253.10 & 532.49 & 6.00 & $4,996.00$ \\
\hline NAF & 567 & 101.33 & 255.30 & 0.00 & $2,453.00$ \\
\hline BIG4 & 567 & 0.81 & 0.39 & 0.00 & 1.00 \\
\hline AOFFICE & 567 & 0.80 & 0.40 & 0.00 & 1.00 \\
\hline FISCAL & 567 & 0.77 & 0.42 & 0.00 & 1.00 \\
\hline $\mathrm{AO}$ & 567 & 0.14 & 0.34 & 0.00 & 1.00 \\
\hline C_AUDITOR & 567 & 0.04 & 0.19 & 0.00 & 1.00 \\
\hline TA $(1,000 \$ N Z)$ & 567 & 561,014 & $1,206,298$ & 113 & $8,276,000$ \\
\hline INVREC & 567 & 0.24 & 0.21 & 0.00 & 0.88 \\
\hline SUB & 567 & 2.55 & 1.52 & 0.00 & 7.62 \\
\hline FOREIGN & 567 & 1.01 & 1.29 & 0.00 & 5.48 \\
\hline LEVE & 567 & 0.51 & 0.53 & 0.00 & 10.43 \\
\hline LIQID & 567 & 3.67 & 20.16 & 0.01 & 457.64 \\
\hline LOSS & 567 & 0.32 & 0.47 & 0.00 & 1.00 \\
\hline CREV & 567 & 5.02 & 84.15 & -1.00 & $1,956.00$ \\
\hline BTM & 567 & 8.31 & 17.87 & -237.92 & 183.56 \\
\hline $\mathrm{CFO}(1,000 \$ N Z)$ & 567 & 47,379 & 173,972 & $-65,570$ & $1,807,000$ \\
\hline VOL_IFRS & 567 & 0.36 & 0.48 & 0.00 & 1.00 \\
\hline EMI & 567 & 0.16 & 0.36 & 0.00 & 1.00 \\
\hline LNTACC & 567 & 8.54 & 2.19 & 0.00 & 14.02 \\
\hline DACC $(1,000 \$ N Z)$ & 567 & 36,697 & 96,841 & 7 & 803,623 \\
\hline
\end{tabular}

${ }^{9}$ The figures summarised in Table 6.2 for the DACCs are determined using the absolute value of the residuals from the Dechow et al. (1995) model multiplied by the Total Assets appearing on each firm's balance sheet lagged by one year. 
The matrix of correlation coefficients between all the variables employed in my empirical analysis as computed across the $\mathrm{N}=567$ firm-years comprising my sample is summarised in Table 6.3. Thus, the product moment correlation coefficient between the total assets variable, LNTA, and the number of subsidiaries variable, SUB, is $r=0.484$. Likewise, the correlation between the total assets variable, LNTA, and the inventory and receivables ratio, INVREC, amounts to $r=-0.171$. The other correlation coefficients summarised in this table are to be similarly interpreted. As expected, the audit fee variable, LNAF, is highly correlated with the natural logarithm of total assets, LNTA, $(r=0.776)$, the number of subsidiaries, SUB, $(r=0.687)$ and the number of foreign subsidiaries, FOREIGN, $(r=0.629)$. Moreover, none of the correlation coefficients exceed the $r=0.80$ threshold at which multicollinearity is considered to affect the integrity of the regression procedures I employ (Gujarati 2009). In this respect, a more detailed summary of the robustness tests that were applied to my regression procedures is to be found in later sections of this chapter. 
Table 6.3: Correlation Coefficients between all Variables across the $N=567$ firm-years covering the Period from 2006 until 2010

\begin{tabular}{|c|c|c|c|c|c|c|c|c|c|c|c|c|c|c|c|c|c|c|c|c|c|c|}
\hline & LNAF & DACC & DACC_1 & BIG4 & FISCAL & AOFFICE & $\begin{array}{l}\text { C_AUD } \\
\text { ITOR }\end{array}$ & $\mathrm{AO}$ & $\mathrm{CFO}$ & LNTA & LEVE & LIQID & LOSS & INVREC & BTM & INVREC & suB & FOREIGN & CREV & VOL_IFRS & EMI & LNTACC \\
\hline LNAF & 1.000 & & & & & & & & & & & & & & & & & & & & & \\
\hline DACC & -0.160 & 1.000 & & & & & & & & & & & & & & & & & & & & \\
\hline DACC_ 1 & -0.107 & 0.222 & 1.000 & & & & & & & & & & & & & & & & & & & \\
\hline BIG4 & 0.338 & -0.133 & -0.150 & 1.000 & & & & & & & & & & & & & & & & & & \\
\hline FISCAL & 0.013 & 0.075 & 0.008 & -0.058 & 1.000 & & & & & & & & & & & & & & & & & \\
\hline AOFFICE & 0.202 & -0.068 & -0.108 & -0.026 & -0.056 & 1.000 & & & & & & & & & & & & & & & & \\
\hline C_AUDITOR & -0.091 & 0.160 & 0.156 & -0.135 & -0.001 & -0.038 & 1.000 & & & & & & & & & & & & & & & \\
\hline $\mathrm{AO}$ & -0.214 & 0.162 & 0.133 & -0.211 & 0.020 & -0.072 & 0.052 & 1.000 & & & & & & & & & & & & & & \\
\hline CFO & 0.474 & -0.084 & -0.063 & 0.131 & 0.077 & 0.104 & -0.047 & -0.106 & 1.000 & & & & & & & & & & & & & \\
\hline LNTA & 0.776 & -0.225 & -0.181 & 0.422 & 0.011 & 0.139 & -0.068 & -0.374 & 0.408 & 1.000 & & & & & & & & & & & & \\
\hline LEVE & 0.080 & 0.105 & 0.096 & -0.077 & 0.050 & -0.086 & 0.059 & 0.176 & 0.012 & -0.071 & 1.000 & & & & & & & & & & & \\
\hline LIQID & -0.097 & 0.216 & -0.034 & 0.036 & -0.005 & 0.027 & -0.006 & -0.031 & -0.029 & -0.013 & -0.096 & 1.000 & & & & & & & & & & \\
\hline LOSS & -0.341 & 0.128 & 0.060 & -0.318 & 0.102 & -0.084 & -0.002 & 0.414 & -0.119 & -0.449 & 0.135 & -0.026 & 1.000 & & & & & & & & & \\
\hline INVREC & 0.098 & 0.012 & -0.002 & -0.029 & -0.050 & -0.156 & -0.016 & 0.050 & -0.091 & -0.171 & 0.135 & -0.081 & 0.015 & 1.000 & & & & & & & & \\
\hline BTM & 0.068 & -0.140 & -0.043 & 0.094 & 0.062 & -0.025 & -0.129 & -0.148 & -0.023 & 0.135 & -0.319 & 0.061 & -0.072 & -0.006 & 1.000 & & & & & & & \\
\hline INVREC & 0.098 & 0.012 & -0.002 & -0.029 & -0.050 & -0.156 & -0.016 & 0.050 & -0.091 & -0.171 & 0.135 & -0.081 & 0.015 & 1.000 & -0.006 & 1.000 & & & & & & \\
\hline SUB & 0.687 & -0.146 & -0.089 & 0.094 & -0.006 & 0.079 & -0.012 & -0.117 & 0.240 & 0.484 & 0.066 & -0.124 & -0.205 & 0.083 & 0.015 & 0.083 & 1.000 & & & & & \\
\hline FOREIGN & 0.629 & -0.048 & -0.043 & 0.146 & -0.009 & 0.081 & -0.026 & -0.143 & 0.291 & 0.307 & 0.061 & -0.073 & -0.146 & 0.191 & -0.042 & 0.191 & 0.671 & 1.000 & & & & \\
\hline CREV & 0.015 & 0.279 & 0.029 & 0.021 & 0.029 & 0.018 & 0.207 & -0.018 & -0.013 & 0.024 & 0.026 & 0.037 & -0.037 & -0.062 & -0.019 & -0.062 & -0.007 & -0.044 & 1.000 & & & \\
\hline VOL_IFRS & 0.229 & 0.065 & 0.029 & -0.028 & -0.006 & 0.180 & -0.037 & -0.066 & 0.193 & 0.100 & -0.024 & -0.028 & -0.111 & -0.036 & -0.030 & -0.036 & 0.136 & 0.179 & -0.025 & 1.000 & & \\
\hline EMI & 0.073 & 0.102 & -0.005 & 0.024 & 0.094 & -0.005 & -0.037 & -0.003 & 0.084 & 0.056 & -0.056 & 0.114 & 0.138 & -0.085 & -0.009 & -0.085 & 0.016 & 0.083 & -0.021 & -0.042 & 1.000 & \\
\hline LNTACC & 0.671 & 0.083 & -0.067 & 0.352 & -0.045 & 0.129 & -0.017 & -0.197 & 0.354 & 0.780 & 0.061 & 0.013 & -0.335 & -0.058 & 0.059 & -0.058 & 0.410 & 0.320 & -0.010 & 0.171 & 0.020 & 1.000 \\
\hline
\end{tabular}




\subsection{Multivariate Tests}

\subsubsection{The Impact of Audit Factors on Discretionary Accruals}

My first set of results examines the impact of the audit factors BIG4, AOFFICE, FISCAL, C_AUDITOR, AO and RNAF on the level of discretionary accruals (DACCs) and are summarised in Table $6.4^{10}$. First, as expected, I find a negative and statistically significant relationship between the BIG4 variable and the level of DACCs (with a t-score of -3.05). This result is consistent with the common perception that higher quality auditors (as proxied by the Big 4 firm dummy variable) will lead to a higher audit quality and this in turn will reduce the level of DACCs. Second, I also observe a negative and significant relationship between the AOFFICE variable and the level of DACCs (with a t-score of -2.04). This result is consistent with Reynolds and Francis (2000), Choi et al. (2010) and Francis and Yu (2009) who also document that audit quality is higher (in my context, DACCs are smaller) when the audit is conducted by an audit team from a major provincial city. Third, Table 6.4 also shows a positive and statistically significant relationship between the FISCAL variable and the level of DACCs (with a t-score of 2.40). This result indicates that the level of DACCs is likely to be higher if the audit is conducted over the period from 31 March to 30 June, which is the busy audit season in New Zealand. Fourth, I find a positive and significant relationship between the AO variable and the level of DACCs (with a t-score of 2.43). This means that a qualified or conditional audit opinion is more likely to occur if the financial statements involve a relatively higher level of DACCs. In contrast, my empirical results report an insignificant relationship between the C_AUDITOR

\footnotetext{
10 The model is described in detail in section 5.3.2.
} 
variable and the level of DACCs (with a t-score of 0.91). This indicates that a change of auditor does not have a statistically significant impact on the level of DACCs. Moreover, my empirical result also fails to report a significant relationship between the RNAF variable and the level of DACCs (with a t-score of -1.17). This means that the provision of a relatively high level of non-audit services by an incumbent auditor has no apparent effect on the level of auditor independence. Overall, the empirical results summarised in Table 6.4 indicate that DACCs are lower (and therefore, audit quality higher) when the audit is conducted by a BIG 4 audit firm and/or an auditor is located in a major provincial city. In contrast, DACCs are larger (and therefore, audit quality lower) when the audit work is conducted in the busy audit season and/or the audit client receives a qualified or conditional audit opinion. Finally, there is no relationship between the level of DACCs (and therefore, the level of audit quality) and the ratio of non-audit services to total audit fees paid (as proxied by the RNAF variable) and/or a change in the audit firm that conducts the audit (as proxied by the C_AUDITOR variable).

Furthermore, several of the estimated coefficients associated with the control variables in the regression model summarised in Table 6.4 also return statistically significant regression coefficients. Specially, I find a positive and marginally significant relationship between the EMI variable and the level of DACCs (with a t-score of 1.65). This result provides marginal (that is, borderline) support for my expectation that a firm which has incentives to manipulate its reported earnings figure will have a higher level of DACCs when compared to firms that have little incentive to manipulate their reported earnings figures. As expected, I also find a positive and significant relationship between the level of DACCs and ratio of current assets divided by current liabilities (LIQID) as well as the client firm's total accruals (LNTACC), the client firm's voluntary adoption of IFRS standards (VOL_IFRS), the client firm's complexity (as proxied by FOREIGN) and the 
proportionate increase in the client firm's sales (as proxied by CREV). In contrast I find a negative and statistically significant relationship between the level of DACCs and the operating cash flow (as proxied by the CFO variable). This indicates that higher operating cash flows reduce the incentive for firms to use discretionary accruals to manipulate their reported earnings figure. However, I do not find a statistically significant relationship between the level of DACCs and the client firm's leverage (LEVE), the client firm's inherent risk (INVREC) and the financial viability of the client firm (LOSS). Table 6.4 also shows a negative relationship between the number of subsidiaries (SUB) controlled by the client firm and the level of the client firm's DACCs. 
Table 6.4: The Relationship between Audit Factors and Discretionary Accruals

DACC $_{j t}=\alpha_{0}+\alpha_{1} \sum$ AuditFactors $_{j t}+\alpha_{2} \sum$ ControlVariables $_{j t}+\varepsilon_{j t}$

\begin{tabular}{|c|c|c|c|}
\hline VARIABLES & $\begin{array}{c}\text { Coefficient/ } \\
\text { Standard Error }\end{array}$ & $\mathbf{t}$ & p-value \\
\hline BIG4 & $\begin{array}{c}-0.07 * * * \\
(0.022)\end{array}$ & -3.05 & 0.0020 \\
\hline AOFFICE & $\begin{array}{c}-0.04 * * \\
(0.020)\end{array}$ & -2.04 & 0.0410 \\
\hline FISCAL & $\begin{array}{l}0.03 * * \\
(0.013)\end{array}$ & 2.40 & 0.0170 \\
\hline C_AUDITOR & $\begin{array}{c}0.06 \\
(0.064)\end{array}$ & 0.91 & 0.3610 \\
\hline $\mathrm{AO}$ & $\begin{array}{l}0.06 * * \\
(0.025)\end{array}$ & 2.43 & 0.0160 \\
\hline RNAF & $\begin{array}{c}-0.04 \\
(0.033)\end{array}$ & -1.17 & 0.2440 \\
\hline $\mathrm{CFO}$ & $\begin{array}{c}-0.00 * * * \\
(0.000)\end{array}$ & -4.42 & 0.0000 \\
\hline LEVE & $\begin{array}{c}0.01 \\
(0.009)\end{array}$ & 0.65 & 0.5170 \\
\hline LIQID & $\begin{array}{c}0.00 * * * \\
(0.000)\end{array}$ & 11.51 & 0.0000 \\
\hline LOSS & $\begin{array}{c}0.03 \\
(0.017)\end{array}$ & 1.54 & 0.1250 \\
\hline INVREC & $\begin{array}{c}0.03 \\
(0.033)\end{array}$ & 0.90 & 0.3710 \\
\hline BTM & $\begin{array}{c}-0.00 * * * \\
(0.000)\end{array}$ & -2.77 & 0.0060 \\
\hline SUB & $\begin{array}{c}-0.03 * * * \\
(0.007)\end{array}$ & -4.33 & 0.0000 \\
\hline FOREIGN & $\begin{array}{l}0.02 * * \\
(0.007)\end{array}$ & 2.48 & 0.0130 \\
\hline CREV & $\begin{array}{c}0.00 * * * \\
(0.000)\end{array}$ & 15.09 & 0.0000 \\
\hline VOL_IFRS & $\begin{array}{l}0.04 * * \\
(0.015)\end{array}$ & 2.50 & 0.0130 \\
\hline EMI & $\begin{array}{c}0.04^{*} \\
(0.025)\end{array}$ & 1.65 & 0.1000 \\
\hline LNTACC & $\begin{array}{c}0.03 * * * \\
(0.004)\end{array}$ & 5.77 & 0.0000 \\
\hline Constant & $\begin{array}{c}-0.00 \\
(0.042)\end{array}$ & -0.07 & 0.9410 \\
\hline Observations & 567 & & \\
\hline R-squared & 0.29 & & \\
\hline Adj. R-squared & 0.27 & & \\
\hline
\end{tabular}




\subsubsection{The Impact of Current Discretionary Accruals on Next Year's Audit Fee}

My second set of results examines the validity of my previously stated hypothesis as to whether the level of DACCs are associated with a disproportionate increase in the audit fee in the next ensuing reporting period. Thus, Table 6.5 summarises the regression results between the natural logarithm of audit fees in the current year (LNAF) and the absolute level of discretionary accruals (DACC_1) in the previous year and where the discretionary accruals (DACCs) are estimated using the modified Jones (1991) model as developed by Dechow et al. (1995). As expected, I find a positive and statistically significant relationship between the level of the audit fee in the current year and the level of the DACCs in the previous year. This means that high levels of DACCs in the previous year will impact positively on the level of the audit fee in the current year.

Furthermore, I also observe positive and significant regression coefficients for the LNTA, IVNREC, SUB, FOREIGN and CREV variables. This in turn means that it is likely that audit fees will rise as firms become bigger and/or more complex in organisational structure and/or operations. Consistent with Knechel et al. (2012), I also find a significant positive coefficient for the LEVE variable and a marginally significant negative coefficient for the LIQID variable. This indicates that audit fees are higher for riskier audit clients but are lower if the client firm indicates lower symptoms of financial distress. Moreover, the coefficients for the BIG4 and AOFFICE variables are positive and significant thereby indicating that there is an audit fee premium associated with the appointment of a Big 4 audit firm or an audit firm whose principal office is located in either Wellington or Auckland. This result contrasts with those of Hay et al. (2006a) and Griffin et al. (2009) which are also based on New Zealand data covering the period from 1999 until 2001 and from 2002 until 2007 respectively, both of whom report an insignificant relationship between the employment of a Big 4 audit firm and the level of audit fees. 
Furthermore, I find a negative and significant relationship between the change in audit firm variable, C_AUDITOR, and the level of audit fees, LNAF. This result is consistent with the "low-balling" hypothesis which states that audit fees will be relatively lower in the first year of a new audit engagement. I also find a positive coefficient for the AO variable which indicates that audit fees are relatively higher for client firms that receive a qualified or conditional audit opinion. Finally, a positive and significant coefficient for the VOL_IFRS variable indicates that audit fees are generally higher for New Zealand firms that have voluntarily adopted IFRS standards before the statutorily required date of 1 January 2007. I also find a positive and significant coefficient for the EMI variable and this in turn means that audit fees are likely to be higher for New Zealand firms that planned to buy back or offer new shares to the stock market in the reporting year. 
Table 6.5: The Relationship between Discretionary Accruals and Audit Fees Paid in the Next Ensuing Year

$\mathrm{LNAF}_{\mathrm{jt}}=\alpha_{0}+\alpha_{1}$ DACC_ $_{-} \mathbf{1}_{\mathrm{jt}}+\alpha_{2} \sum$ ControlVariables $\mathrm{jt}_{\mathrm{jt}}+\varepsilon_{\mathrm{jt}}$

\begin{tabular}{|c|c|c|c|}
\hline VARIABLES & $\begin{array}{c}\text { Coefficient// } \\
\text { Standard Error }\end{array}$ & $\mathbf{t}$ & $P>t$ \\
\hline DACC_1 & $\begin{array}{c}0.18^{* * * *} \\
(0.065)\end{array}$ & 2.81 & 0.005 \\
\hline BIG4 & $\begin{array}{l}0.15^{* *} \\
(0.071)\end{array}$ & 2.16 & 0.031 \\
\hline AOFFICE & $\begin{array}{c}0.32 * * * \\
(0.055)\end{array}$ & 5.77 & 0.000 \\
\hline FISCAL & $\begin{array}{c}0.04 \\
(0.049)\end{array}$ & 0.88 & 0.377 \\
\hline C_AUDITOR & $\begin{array}{c}-0.24 * * * * \\
(0.094)\end{array}$ & -2.61 & 0.009 \\
\hline $\mathrm{AO}$ & $\begin{array}{c}0.28 * * * \\
(0.069)\end{array}$ & 4.12 & 0.000 \\
\hline LNTA & $\begin{array}{c}0.35 * * * \\
(0.014)\end{array}$ & 24.39 & 0.000 \\
\hline LEVE & $\begin{array}{c}0.19 * * * \\
(0.069)\end{array}$ & 2.74 & 0.006 \\
\hline LIQID & $\begin{array}{l}-0.00^{*} \\
(0.001)\end{array}$ & -1.83 & 0.068 \\
\hline BTM & $\begin{array}{c}0.00 \\
(0.001)\end{array}$ & 1.49 & 0.136 \\
\hline INVREC & $\begin{array}{c}0.84 * * * \\
(0.114)\end{array}$ & 7.38 & 0.000 \\
\hline SUB & $\begin{array}{c}0.13 * * * \\
(0.022)\end{array}$ & 6.12 & 0.000 \\
\hline FOREIGN & $\begin{array}{l}0.25 * * * \\
(0.024)\end{array}$ & 10.47 & 0.000 \\
\hline CREV & $\begin{array}{l}0.00 * * \\
(0.000)\end{array}$ & 2.09 & 0.037 \\
\hline VOL_IFRS & $\begin{array}{c}0.22 * * * \\
(0.044)\end{array}$ & 5.06 & 0.000 \\
\hline EMI & $\begin{array}{l}0.12 * * \\
(0.052)\end{array}$ & 2.26 & 0.024 \\
\hline Constant & $\begin{array}{c}-0.77 * * * * \\
(0.154) \\
\end{array}$ & -4.99 & 0.000 \\
\hline $\begin{array}{l}\text { Observations } \\
\text { R-squared } \\
\text { Adj.R-squared }\end{array}$ & $\begin{array}{l}567 \\
0.84 \\
0.84\end{array}$ & & \\
\hline
\end{tabular}




\subsection{Robustness and Sensitivity Tests}

I now summarise several robustness tests which were applied to my data in order to assess the reliability and validity of my main empirical results. These tests will help to evaluate whether a third party who sought to replicate my empirical analysis would draw the same conclusions from my data set as those summarised in this thesis.

\subsubsection{Tests for Discretionary Accruals Models}

\subsubsection{Heteroscedasticity Issues}

In order to mitigate econometric issues associated with heteroscedastic error terms, I have applied the White (1980) adjustment procedure to all regressions models summarised in section 6.2.1. Here, Table 6.6 provides a brief comparison between the $\mathrm{t}$-scores obtained under the standard OLS regression assumptions and the $\mathrm{t}$ scores based on the White (1980) adjustment procedure.

Table 6.6 shows that there are significant changes in some of the t-scores under the White (1980) adjustment procedure. For example, the C_AUDITOR variable returns a marginally significant $\mathrm{t}$-score under standard OLS assumptions but the tscore for this variable becomes insignificant at all conventional levels under the White (1980) adjustment procedure. This contrasts with the FISCAL variable which returns only a marginally significant t-score under standard OLS assumptions but a highly significant t-score when the White (1980) adjustment procedure is applied. 
Table 6.6: Standard OLS Regression versus OLS Regression with White (1980) Adjustment

DACC $_{j \mathrm{t}}=\alpha_{0}+\alpha_{1} \sum$ AuditFactors $_{\mathrm{jt}}+\alpha_{2} \sum$ ControlVariables $_{\mathrm{jt}}+\varepsilon_{\mathrm{jt}}$

\begin{tabular}{|c|c|c|c|c|}
\hline \multirow[b]{2}{*}{ VARIABLES } & \multicolumn{2}{|c|}{ OLS Regression } & \multicolumn{2}{|c|}{ Robust OLS Regression } \\
\hline & $\begin{array}{c}\text { Coefficient/ } \\
\text { Standard Error }\end{array}$ & $\mathrm{t}$ & $\begin{array}{c}\text { Coefficient/ } \\
\text { Standard Error }\end{array}$ & $\mathrm{T}$ \\
\hline BIG4 & $\begin{array}{c}-0.07 * * * \\
(0.019)\end{array}$ & -3.50 & $\begin{array}{c}-0.07 * * * \\
(0.022)\end{array}$ & -3.05 \\
\hline AOFFICE & $\begin{array}{l}-0.04 * * \\
(0.017)\end{array}$ & -2.45 & $\begin{array}{c}-0.04 * * \\
(0.020)\end{array}$ & -2.04 \\
\hline FISCAL & $\begin{array}{c}0.03^{*} \\
(0.016)\end{array}$ & 1.91 & $\begin{array}{l}0.03 * * \\
(0.013)\end{array}$ & 2.40 \\
\hline C_AUDITOR & $\begin{array}{c}0.06^{*} \\
(0.035)\end{array}$ & 1.66 & $\begin{array}{c}0.06 \\
(0.064)\end{array}$ & 0.91 \\
\hline $\mathrm{AO}$ & $\begin{array}{c}0.06^{* * * *} \\
(0.021)\end{array}$ & 2.84 & $\begin{array}{l}0.06 * * \\
(0.025)\end{array}$ & 2.43 \\
\hline RNAF & $\begin{array}{c}-0.04 \\
(0.034)\end{array}$ & -1.13 & $\begin{array}{c}-0.04 \\
(0.033)\end{array}$ & -1.17 \\
\hline $\mathrm{CFO}$ & $\begin{array}{c}-0.00 * * * \\
(0.000)\end{array}$ & -3.40 & $\begin{array}{c}-0.00 * * * \\
(0.000)\end{array}$ & -4.42 \\
\hline LEVE & $\begin{array}{c}0.01 \\
(0.013)\end{array}$ & 0.45 & $\begin{array}{c}0.01 \\
(0.009)\end{array}$ & 0.65 \\
\hline LIQID & $\begin{array}{l}0.00 * * * \\
(0.000)\end{array}$ & 5.24 & $\begin{array}{c}0.00 * * * \\
(0.000)\end{array}$ & 11.51 \\
\hline LOSS & $\begin{array}{c}0.03 \\
(0.017)\end{array}$ & 1.59 & $\begin{array}{c}0.03 \\
(0.017)\end{array}$ & 1.54 \\
\hline INVREC & $\begin{array}{c}0.03 \\
(0.032)\end{array}$ & 0.90 & $\begin{array}{c}0.03 \\
(0.033)\end{array}$ & 0.90 \\
\hline BTM & $\begin{array}{c}-0.00 * * * \\
(0.000)\end{array}$ & -2.78 & $\begin{array}{c}-0.00 * * * \\
(0.000)\end{array}$ & -2.77 \\
\hline SUB & $\begin{array}{c}-0.03 * * * \\
(0.006)\end{array}$ & -4.93 & $\begin{array}{c}-0.03 * * * \\
(0.007)\end{array}$ & -4.33 \\
\hline FOREIGN & $\begin{array}{l}0.02 * * \\
(0.007)\end{array}$ & 2.28 & $\begin{array}{l}0.02 * * \\
(0.007)\end{array}$ & 2.48 \\
\hline CREV & $\begin{array}{c}0.00 * * * \\
(0.000)\end{array}$ & 7.40 & $\begin{array}{c}0.00 * * * \\
(0.000)\end{array}$ & 15.09 \\
\hline VOL_IFRS & $\begin{array}{c}0.04 * * * \\
(0.014)\end{array}$ & 2.60 & $\begin{array}{l}0.04 * * \\
(0.015)\end{array}$ & 2.50 \\
\hline EMI & $\begin{array}{l}0.04 * * \\
(0.019)\end{array}$ & 2.19 & $\begin{array}{c}0.04 * \\
(0.025)\end{array}$ & 1.65 \\
\hline LNTACC & $\begin{array}{c}0.03 * * * \\
(0.004)\end{array}$ & 6.72 & $\begin{array}{c}0.03 * * * \\
(0.004)\end{array}$ & 5.77 \\
\hline Constant & $\begin{array}{c}-0.00 \\
(0.039)\end{array}$ & -0.08 & $\begin{array}{c}-0.00 \\
(0.042)\end{array}$ & -0.07 \\
\hline $\begin{array}{l}\text { Observations } \\
\text { R-squared } \\
\text { Adj. R-squared }\end{array}$ & $\begin{array}{l}567 \\
0.29 \\
0.27 \\
\end{array}$ & & $\begin{array}{l}567 \\
0.29 \\
0.27 \\
\end{array}$ & \\
\hline
\end{tabular}

Standard errors in parentheses

$* * * \mathrm{p}<0.01, * * \mathrm{p}<0.05, * \mathrm{p}<0.10$ 


\subsubsection{Multicolinearity Issues}

I also use the variance inflation factor (VIF) and the Condition Index Test to check for issues of multicolinearity that might arise with my discretionary accruals regression model. Here Table 6.7 shows that all the variance inflation factors (VIF) associated with my regression outputs are well within the limit of 3 above which, a regression procedure is considered to be affected by problems of co-linear independent variables (O'Brien 2007). Furthermore, the Condition Index Test based on the eigenvalues of the matrix of correlation coefficients between the independent variables comprising my regression models as summarised in Table 6.8, is well within the limit of thirty at which issues of multicolinearity are considered to become an issue (Belsley et al., 1980). Thus, the both the VIF and Condition Index Tests support the proposition that there is little evidence that the parameter estimates and their associated t-scores obtained from my discretionary accuals regression model are affected by issues of co-linear independent variables.

Table 6.7: Multicolinearity Tests for Discretionary Accruals model (Using VIF Factor)

\begin{tabular}{|l|c|c|c|c|}
\hline \multicolumn{1}{|c|}{ Variable } & VIF & SQRT VIF & Tolerance & R-Squared \\
\hline BIG4 & 1.30 & 1.14 & 0.7718 & 0.2282 \\
\hline FISCAL & 1.05 & 1.02 & 0.9554 & 0.0446 \\
\hline AOFFICE & 1.10 & 1.05 & 0.9126 & 0.0874 \\
\hline C_AUDITOR & 1.09 & 1.05 & 0.9136 & 0.0864 \\
\hline AO & 1.27 & 1.13 & 0.7863 & 0.2137 \\
\hline CFO & 1.25 & 1.12 & 0.8014 & 0.1986 \\
\hline LEVE & 1.22 & 1.11 & 0.8184 & 0.1816 \\
\hline LIQID & 1.05 & 1.03 & 0.9512 & 0.0488 \\
\hline LOSS & 1.45 & 1.20 & 0.6890 & 0.3110 \\
\hline INVREC & 1.14 & 1.07 & 0.8753 & 0.1247 \\
\hline BTM & 1.18 & 1.09 & 0.8486 & 0.1514 \\
\hline SUB & 2.06 & 1.43 & 0.4857 & 0.5143 \\
\hline FOREIGN & 2.07 & 1.44 & 0.4827 & 0.5173 \\
\hline CREV & 1.06 & 1.03 & 0.9432 & 0.0568 \\
\hline VOL_IFRS & 1.11 & 1.06 & 0.8977 & 0.1023 \\
\hline EMI & 1.09 & 1.04 & 0.9212 & 0.0788 \\
\hline LNTACC & 1.60 & 1.26 & 0.6249 & 0.3751 \\
\hline Mean VIF & $\mathbf{1 . 3 0}$ & & & \\
\hline
\end{tabular}


Table 6.8: Multicolinearity Tests for Discretionary Accruals Model (Using Condition Index)

\begin{tabular}{|c|c|c|c|c|c|}
\hline No & Eigenvalue & Condition Index & No & Eigenvalue & Condition Index \\
\hline 1 & 8.2004 & 1.0000 & 10 & 0.5069 & 4.0222 \\
\hline 2 & 1.4315 & 2.3935 & 11 & 0.4220 & 4.4084 \\
\hline 3 & 1.1963 & 2.6182 & 12 & 0.3727 & 4.6909 \\
\hline 4 & 1.1336 & 2.6896 & 13 & 0.3378 & 4.9271 \\
\hline 5 & 0.9639 & 2.9167 & 14 & 0.2126 & 6.2109 \\
\hline 6 & 0.8052 & 3.1912 & 15 & 0.1787 & 6.7737 \\
\hline 7 & 0.7597 & 3.2854 & 16 & 0.1215 & 8.2167 \\
\hline 8 & 0.7052 & 3.4101 & 17 & 0.0507 & 12.7226 \\
\hline 9 & 0.5816 & 3.7551 & 18 & 0.0198 & 20.3588 \\
\hline \multicolumn{5}{|l|}{ Condition Number } & \\
\hline
\end{tabular}

\subsubsection{OLS Regression with Cluster Option}

It is possible that the level of DACCs among different firms within a year or different years within a firm may not be independent, and this could lead to residuals that are not independent within years or firms. I use OLS regression with the cluster option (by firm and year) to allow for this possibility. Table 6.9 summarises the results for the two cluster regressions; namely, by firm (based on a sample of 142 firms) and by year (based on a sample of 5 years) as well as the OLS regression results without the cluster option. ${ }^{11}$

Overall, the regression results regarding the relationship between audit factors and the level of DACCs remain unchanged when the cluster option is applied. In particular, the regression results show a significant relationship beyond the 10 per cent level (and occasionally the 1\% level) between the level of DACCs and the

11 All $\mathrm{t}$ statistics for the cluster regression based on the sample of 142 firms have $v=141$ degrees of freedom. All statistics for the cluster regression based on the sample of 5 years have $v=4$ degrees of freedom (StataCorp 2013, p. 312). 
BIG4, AOFFICE, FISCAL and AO variables. However, both the standard OLS regression and the two regression procedures using the cluster option fail to report a significant relationship between the C_AUDITOR variable, the RNAF variable and the level of DACCs. There are only some very minor changes in the significance levels of some of the variables using the cluster option regression procedures. For example, the significance level of the BIG4 variable is 1 percent in the overall OLS regression and the OLS regression clustered by firms. In contrast, the significance level is at 5 percent for the OLS regression clustered by years. The AO variable is significant at the 5 percent level in the overall OLS regression whereas it is significant at the 1 percent and 10 percent levels, respectively in the OLS regressions clustered by firms and by years. 
Table 6.9: Discretionary Accruals Model with Cluster Option by Firms and Years

DACC $_{j t}=\alpha_{0}+\alpha_{1} \sum$ AuditFactors $_{j t}+\alpha_{2} \sum$ ControlVariables $_{j t}+\varepsilon_{j t}$

\begin{tabular}{|c|c|c|c|c|c|c|}
\hline \multirow{2}{*}{ VARIABLES } & \multicolumn{2}{|c|}{$\begin{array}{l}\text { Clustered by } \\
142 \text { firms }\end{array}$} & \multicolumn{2}{|c|}{$\begin{array}{l}\text { Clustered by } \\
5 \text { years }\end{array}$} & \multicolumn{2}{|c|}{$\begin{array}{l}\text { OLS regression (presented } \\
\text { in section 6.2.1) }\end{array}$} \\
\hline & $\begin{array}{l}\text { Coefficient/ } \\
\text { Standard Error }\end{array}$ & $\mathrm{t}$ & $\begin{array}{l}\text { Coefficient/ } \\
\text { Standard Error }\end{array}$ & $\mathrm{t}$ & $\begin{array}{l}\text { Coefficient/ } \\
\text { Standard Error }\end{array}$ & $\mathrm{t}$ \\
\hline$\overline{B I G 4}$ & $\begin{array}{c}-0.07 * * * \\
(0.025)\end{array}$ & -2.66 & $\begin{array}{c}-0.07 * * \\
(0.020)\end{array}$ & -3.39 & $\begin{array}{c}-0.07 * * * \\
(0.022)\end{array}$ & -3.05 \\
\hline AOFFICE & $\begin{array}{l}-0.04 * * \\
(0.020)\end{array}$ & -2.07 & $\begin{array}{l}-0.04 * \\
(0.017)\end{array}$ & -2.51 & $\begin{array}{l}-0.04 * * \\
(0.020)\end{array}$ & -2.04 \\
\hline FISCAL & $\begin{array}{c}0.03^{*} \\
(0.015)\end{array}$ & 1.96 & $\begin{array}{c}0.03^{*} \\
(0.012)\end{array}$ & 2.58 & $\begin{array}{l}0.03 * * \\
(0.013)\end{array}$ & 2.40 \\
\hline C_AUDITOR & $\begin{array}{c}0.06 \\
(0.062)\end{array}$ & 0.94 & $\begin{array}{c}0.06 \\
(0.043)\end{array}$ & 1.34 & $\begin{array}{c}0.06 \\
(0.064)\end{array}$ & 0.91 \\
\hline $\mathrm{AO}$ & $\begin{array}{c}0.06 * * * * \\
(0.021)\end{array}$ & 2.81 & $\begin{array}{c}0.06^{*} \\
(0.024)\end{array}$ & 2.46 & $\begin{array}{l}0.06 * * \\
(0.025)\end{array}$ & 2.43 \\
\hline RNAF & $\begin{array}{c}-0.04 \\
(0.039)\end{array}$ & -1.00 & $\begin{array}{l}-0.04 \\
(0.020)\end{array}$ & -1.99 & $\begin{array}{c}-0.04 \\
(0.033)\end{array}$ & -1.17 \\
\hline $\mathrm{CFO}$ & $\begin{array}{r}-0.00 * * \\
(0.000)\end{array}$ & -2.57 & $\begin{array}{c}-0.00 * * * \\
(0.000)\end{array}$ & -8.58 & $\begin{array}{c}-0.00 * * * \\
(0.000)\end{array}$ & -4.42 \\
\hline LEVE & $\begin{array}{c}0.01 \\
(0.011)\end{array}$ & 0.55 & $\begin{array}{c}0.01 \\
(0.010)\end{array}$ & 0.59 & $\begin{array}{c}0.01 \\
(0.009)\end{array}$ & 0.65 \\
\hline LIQID & $\begin{array}{c}0.00 * * * \\
(0.000)\end{array}$ & 10.69 & $\begin{array}{c}0.00 * * * \\
(0.000)\end{array}$ & 9.54 & $\begin{array}{l}0.00 * * * \\
(0.000)\end{array}$ & 11.51 \\
\hline LOSS & $\begin{array}{c}0.03 \\
(0.018)\end{array}$ & 1.51 & $\begin{array}{c}0.03 \\
(0.016)\end{array}$ & 1.70 & $\begin{array}{c}0.03 \\
(0.017)\end{array}$ & 1.54 \\
\hline INVREC & $\begin{array}{c}0.03 \\
(0.036)\end{array}$ & 0.81 & $\begin{array}{c}0.03 \\
(0.042)\end{array}$ & 0.70 & $\begin{array}{c}0.03 \\
(0.033)\end{array}$ & 0.90 \\
\hline BTM & $\begin{array}{c}-0.00 * * * \\
(0.000)\end{array}$ & -2.64 & $\begin{array}{l}-0.00 * \\
(0.000)\end{array}$ & -2.54 & $\begin{array}{l}-0.00 * * * \\
(0.000)\end{array}$ & -2.77 \\
\hline SUB & $\begin{array}{c}-0.03 * * * \\
(0.008)\end{array}$ & -3.92 & $\begin{array}{c}-0.03 * * * \\
(0.005)\end{array}$ & -5.82 & $\begin{array}{c}-0.03 * * * \\
(0.007)\end{array}$ & -4.33 \\
\hline FOREIGN & $\begin{array}{l}0.02 * * \\
(0.008)\end{array}$ & 2.09 & $\begin{array}{l}0.02 * * \\
(0.005)\end{array}$ & 3.55 & $\begin{array}{l}0.02 * * \\
(0.007)\end{array}$ & 2.48 \\
\hline CREV & $\begin{array}{c}0.00 * * * \\
(0.000)\end{array}$ & 14.47 & $\begin{array}{c}0.00 * * * \\
(0.000)\end{array}$ & 26.34 & $\begin{array}{c}0.00 * * * \\
(0.000)\end{array}$ & 15.09 \\
\hline VOL_IFRS & $\begin{array}{l}0.04 * * \\
(0.018)\end{array}$ & 2.05 & $\begin{array}{l}0.04 * * \\
(0.008)\end{array}$ & 4.47 & $\begin{array}{l}0.04 * * \\
(0.015)\end{array}$ & 2.50 \\
\hline EMI & $\begin{array}{c}0.04 \\
(0.027)\end{array}$ & 1.49 & $\begin{array}{c}0.04 * \\
(0.018)\end{array}$ & 2.27 & $\begin{array}{c}0.04^{*} \\
(0.025)\end{array}$ & 1.65 \\
\hline LNTACC & $\begin{array}{c}0.03 * * * \\
(0.005)\end{array}$ & 5.17 & $\begin{array}{c}0.03 * * * \\
(0.005)\end{array}$ & 4.96 & $\begin{array}{c}0.03 * * * \\
(0.004)\end{array}$ & 5.77 \\
\hline Constant & $\begin{array}{c}-0.00 \\
(0.049) \\
\end{array}$ & -0.06 & $\begin{array}{c}-0.00 \\
(0.035) \\
\end{array}$ & -0.09 & $\begin{array}{c}-0.00 \\
(0.042) \\
\end{array}$ & -0.07 \\
\hline Observations & 567 & & 567 & & 567 & \\
\hline R-squared & 0.29 & & 0.29 & & 0.29 & \\
\hline Adj. R-squared & 0.27 & & 0.27 & & 0.27 & \\
\hline
\end{tabular}

Robust standard errors in parentheses

$* * * \mathrm{p}<0.01, * * \mathrm{p}<0.05, * \mathrm{p}<0.10$ 


\subsubsection{Regression with Measurement Error}

One of the assumptions of the standard OLS regression procedure is that the independent variables are measured without error. When, however, independent variables are measured with error - as will surely be the case with the discretionary accruals model on which my empirical analysis is based - then under the standard scenario the measurement errors in the independent variables will bias the regression coefficients towards zero (Greene 2012). I thus use the "eivreg regression" option in the STATA software package to make allowances for potential measurement errors when estimating the coefficients for the discretionary accruals regression model. Table 6.10 provides summary details of the changes that occur between the discretionary accruals regression model based on standard OLS procedures and the OLS procedures with the "eivreg regression" option.

As can be seen from Table 6.10, there are a few differences in the parameter estimates and their associated t-scores under the two regression procedures. For example, the t-score associated with the coefficient for the C_AUDITOR variable increases from a statistically insignificant 0.91 under standard OLS regression procedures to 1.66 under the OLS procedure with the "eivreg regression" option. This in turn means there is a marginally significant relationship between the C_AUDITOR variable and the level of DACCs under the OLS procedure with the "eivreg regression" option. There are also small changes in the t-scores obtained for some of the other variables but these changes do not affect the conclusions I present in section 6.2.1 about the impact of the audit factors on the level of DACCs. 
Table 6.10: Regression Results with "eivreg regression" Option for Discretionary Accruals Model

DACC $_{j \mathrm{t}}=\alpha_{0}+\alpha_{1} \sum$ AuditFactors $_{\mathrm{jt}}+\alpha_{2} \sum$ ControlVariables $_{\mathrm{jt}}+\varepsilon_{\mathrm{jt}}$

\begin{tabular}{|c|c|c|c|c|}
\hline \multirow{2}{*}{ VARIABLES } & \multicolumn{2}{|c|}{$\begin{array}{c}\text { Standard OLS } \\
\text { Regression Results }\end{array}$} & \multicolumn{2}{|c|}{$\begin{array}{l}\text { OLS Regression with } \\
\text { "eivreg regression” option }\end{array}$} \\
\hline & $\begin{array}{c}\text { Coefficient/ } \\
\text { Standard Error }\end{array}$ & $\mathrm{t}$ & $\begin{array}{c}\text { Coefficient/ } \\
\text { Standard Error } \\
\end{array}$ & $\mathrm{t}$ \\
\hline BIG4 & $\begin{array}{c}-0.07 * * * \\
(0.019)\end{array}$ & -3.50 & $\begin{array}{c}-0.07 * * * \\
(0.022)\end{array}$ & -3.05 \\
\hline AOFFICE & $\begin{array}{l}-0.04 * * \\
(0.017)\end{array}$ & -2.45 & $\begin{array}{l}-0.04 * * \\
(0.020)\end{array}$ & -2.04 \\
\hline FISCAL & $\begin{array}{c}0.03^{*} \\
(0.016)\end{array}$ & 1.91 & $\begin{array}{l}0.03 * * \\
(0.013)\end{array}$ & 2.40 \\
\hline C_AUDITOR & $\begin{array}{c}0.06^{*} \\
(0.035)\end{array}$ & 1.66 & $\begin{array}{c}0.06 \\
(0.064)\end{array}$ & 0.91 \\
\hline $\mathrm{AO}$ & $\begin{array}{c}0.06^{* * * *} \\
(0.021)\end{array}$ & 2.84 & $\begin{array}{l}0.06 * * \\
(0.025)\end{array}$ & 2.43 \\
\hline RNAF & $\begin{array}{l}-0.04 \\
(0.034)\end{array}$ & -1.12 & $\begin{array}{c}-0.04 \\
(0.033)\end{array}$ & -1.17 \\
\hline $\mathrm{CFO}$ & $\begin{array}{c}-0.00 * * * \\
(0.000)\end{array}$ & -3.40 & $\begin{array}{c}-0.00 * * * \\
(0.000)\end{array}$ & -4.42 \\
\hline LEVE & $\begin{array}{c}0.01 \\
(0.013)\end{array}$ & 0.45 & $\begin{array}{c}0.01 \\
(0.009)\end{array}$ & 0.65 \\
\hline LIQID & $\begin{array}{c}0.00 * * * \\
(0.000)\end{array}$ & 5.24 & $\begin{array}{c}0.00 * * * \\
(0.000)\end{array}$ & 11.51 \\
\hline LOSS & $\begin{array}{c}0.03 \\
(0.017)\end{array}$ & 1.59 & $\begin{array}{c}0.03 \\
(0.017)\end{array}$ & 1.54 \\
\hline INVREC & $\begin{array}{c}0.03 \\
(0.032)\end{array}$ & 0.90 & $\begin{array}{c}0.03 \\
(0.033)\end{array}$ & 0.90 \\
\hline BTM & $\begin{array}{c}-0.00 * * * \\
(0.000)\end{array}$ & -2.78 & $\begin{array}{c}-0.00 * * * \\
(0.000)\end{array}$ & -2.77 \\
\hline SUB & $\begin{array}{c}-0.03 * * * \\
(0.006)\end{array}$ & -4.92 & $\begin{array}{c}-0.03 * * * \\
(0.007)\end{array}$ & -4.33 \\
\hline FOREIGN & $\begin{array}{l}0.02 * * \\
(0.007)\end{array}$ & 2.28 & $\begin{array}{l}0.02 * * \\
(0.007)\end{array}$ & 2.48 \\
\hline CREV & $\begin{array}{c}0.00 * * * \\
(0.000)\end{array}$ & 7.40 & $\begin{array}{l}0.00 * * * \\
(0.000)\end{array}$ & 15.09 \\
\hline VOL_IFRS & $\begin{array}{c}0.04 * * * \\
(0.014)\end{array}$ & 2.60 & $\begin{array}{l}0.04 * * \\
(0.015)\end{array}$ & 2.50 \\
\hline EMI & $\begin{array}{l}0.04 * * \\
(0.019)\end{array}$ & 2.19 & $\begin{array}{l}0.04^{*} \\
(0.025)\end{array}$ & 1.65 \\
\hline LNTACC & $\begin{array}{c}0.03 * * * \\
(0.004)\end{array}$ & 6.72 & $\begin{array}{l}0.03 * * * \\
(0.004)\end{array}$ & 5.77 \\
\hline Constant & $\begin{array}{c}-0.00 \\
(0.039) \\
\end{array}$ & -0.08 & $\begin{array}{c}-0.00 \\
(0.042) \\
\end{array}$ & -0.07 \\
\hline $\begin{array}{l}\text { Observations } \\
\text { R-squared } \\
\text { Adj. R-squared }\end{array}$ & $\begin{array}{c}567 \\
0.29 \\
\end{array}$ & & $\begin{array}{l}567 \\
0.29 \\
0.27\end{array}$ & \\
\hline
\end{tabular}

Standard errors in parentheses $* * * \mathrm{p}<0.01, * * \mathrm{p}<0.05, * \mathrm{p}<0.10$ 


\subsubsection{Alternative Methods of Discretionary Accruals}

I also test the robustness of my results by using several alternative measures of discretionary accruals. First, I use total accruals as a proxy for earnings management. As previously noted (as in section 2.1.4), Healy (1985) argues that total accruals ought to be a good proxy for the way in which a firm has manipulated its reported earnings. Given this, my first alternative measure of discretionary accruals is based on the total accruals itself. Second, I use the original Jones (1991) model and the amended specification of the modified Jones (1991) model as developed by Kothari et al. (2005), to calculate discretionary accruals ${ }^{12}$. My empirical results obtained for the modified Jones (1991) model as summarised in Table 6.4 (as in section 6.2.1) and reproduced in Table 6.11, are virtually indistinguishable from the empirical results summarised in Table 6.11 for the original Jones (1991) model and the Kothari et al. (2005) specification for the amended Jones (1991) model. In particular, for all three models [that is, the original Jones (1991) model, the modified Jones (1991) model and the Kothari et al. (2005) specification for the amended Jones (1991) model]:

(1) Discretionary accruals are lower when the audit is conducted by a BIG 4 audit firm and/or an auditor is located in a major provincial city (that is, Auckland or Wellington) as proxied by the AOFFICE variable,

(2) Discretionary accruals are larger when the audit work is conducted in the busy audit season (the BUSY variable) and/or the audit client receives a qualified or conditional audit opinion (the $\mathrm{AO}$ variable), and

\footnotetext{
12 The Healy (1985) model and original Jones (1991) model of the accruals process as well as the modified Jones (1991) model are summarised in section 2.1.4 in this thesis.
} 
(3) There is no apparent relationship between the level of DACCs and the level of non-audit services provided by an incumbent auditor (the RNAF variable) and/or a change in the audit firm that conducts the audit (the C_AUDITOR variable).

However, Table 6.11 shows that the relationship between DACCs and the various audit factors for the Healy (1995) model is very different to the other three models applied in my empirical analysis. For example, the estimated coefficients associated with the BIG4 and AOFFICE variables in the Healy (1985) model are both positive and significantly different from zero. In contrast, the estimated coefficients associated with the BIG4 and AOFFICE variables in the original Jones (1991), the modified Jones (1991) and the Kothari et al. (2005) specification for the amended Jones (1991) model are all negative (and approximately the same value) and significantly different from zero. This result may be driven by the fact that total accruals are an intervening variable for factors such as business strategy, industry conventions, macro-economic events and other economic factors (Ronen and Yaari 2007). This in turn will mean that the Healy (1985) model will provide an inefficient specification of the relationship between accruals and their determining audit factors. 
Table 6.11: Alternative Methods for Estimating Discretionary Accruals

DACC $_{j \mathrm{t}}=\alpha_{0}+\alpha_{1} \sum$ AuditFactors $_{\mathrm{jt}}+\alpha_{2} \sum$ ControlVariables $_{\mathrm{jt}}+\varepsilon_{\mathrm{jt}}$

\begin{tabular}{|c|c|c|c|c|c|c|c|c|}
\hline \multirow{2}{*}{ VARIABLES } & \multicolumn{2}{|c|}{$\begin{array}{c}\begin{array}{c}\text { Healy (1985) } \\
\text { model }\end{array} \\
\end{array}$} & \multicolumn{2}{|c|}{$\begin{array}{c}\begin{array}{c}\text { Original Jones (1991) } \\
\text { model }\end{array} \\
\end{array}$} & \multicolumn{2}{|c|}{$\begin{array}{c}\text { Amended Jones (1991) model by } \\
\text { Kothari et al. (2005) }\end{array}$} & \multicolumn{2}{|c|}{$\begin{array}{c}\text { Modified Jones (1991) } \\
\text { model by Dechow (1995) }\end{array}$} \\
\hline & $\begin{array}{l}\text { Coefficient/ } \\
\text { Standard Error }\end{array}$ & $\mathrm{t}$ & $\begin{array}{c}\text { Coefficient/ } \\
\text { Standard Error }\end{array}$ & $\mathrm{t}$ & $\begin{array}{c}\text { Coefficient/ } \\
\text { Standard Error }\end{array}$ & $\mathrm{t}$ & $\begin{array}{c}\text { Coefficient/ } \\
\text { Standard Error }\end{array}$ & $\mathrm{t}$ \\
\hline BIG4 & $\begin{array}{l}1.37 * * * \\
(0.222)\end{array}$ & 6.18 & $\begin{array}{c}-0.07 * * * \\
(0.022)\end{array}$ & -3.09 & $\begin{array}{c}-0.07 * * * \\
(0.022)\end{array}$ & -3.04 & $\begin{array}{c}-0.07 * * * \\
(0.022)\end{array}$ & -3.05 \\
\hline AOFFICE & $\begin{array}{c}0.38^{*} \\
(0.194)\end{array}$ & 1.94 & $\begin{array}{r}-0.04 * * \\
(0.020)\end{array}$ & -2.06 & $\begin{array}{r}-0.04 * * \\
(0.021)\end{array}$ & -2.03 & $\begin{array}{l}-0.04 * * \\
(0.020)\end{array}$ & -2.04 \\
\hline FISCAL & $\begin{array}{l}-0.20 \\
(0.162)\end{array}$ & -1.26 & $\begin{array}{l}0.03 * * \\
(0.013)\end{array}$ & 2.47 & $\begin{array}{l}0.03 * * \\
(0.013)\end{array}$ & 2.34 & $\begin{array}{l}0.03 * * \\
(0.013)\end{array}$ & 2.40 \\
\hline C_AUDITOR & $\begin{array}{c}0.52 \\
(0.341)\end{array}$ & 1.52 & $\begin{array}{c}0.06 \\
(0.065)\end{array}$ & 0.91 & $\begin{array}{c}0.06 \\
(0.064)\end{array}$ & 0.91 & $\begin{array}{c}0.06 \\
(0.064)\end{array}$ & 0.91 \\
\hline $\mathrm{AO}$ & $\begin{array}{c}-0.15 \\
(0.256)\end{array}$ & -0.60 & $\begin{array}{l}0.06 * * \\
(0.025)\end{array}$ & 2.42 & $\begin{array}{l}0.06^{* *} \\
(0.025)\end{array}$ & 2.40 & $\begin{array}{l}0.06^{* *} \\
(0.025)\end{array}$ & 2.43 \\
\hline RNAF & $\begin{array}{c}0.21 \\
(0.380)\end{array}$ & 0.55 & $\begin{array}{c}-0.04 \\
(0.033)\end{array}$ & -1.12 & $\begin{array}{c}-0.04 \\
(0.033)\end{array}$ & -1.18 & $\begin{array}{c}-0.04 \\
(0.033)\end{array}$ & -1.17 \\
\hline $\mathrm{CFO}$ & $\begin{array}{c}0.00 * * * \\
(0.000)\end{array}$ & 4.65 & $\begin{array}{l}-0.00 * * * \\
(0.000)\end{array}$ & -4.39 & $\begin{array}{c}-0.00 * * * \\
(0.000)\end{array}$ & -4.38 & $\begin{array}{c}-0.00 * * * \\
(0.000)\end{array}$ & -4.42 \\
\hline LEVE & $\begin{array}{c}0.53 \\
(0.443)\end{array}$ & 1.19 & $\begin{array}{c}0.00 \\
(0.010)\end{array}$ & 0.49 & $\begin{array}{c}0.01 \\
(0.009)\end{array}$ & 0.88 & $\begin{array}{c}0.01 \\
(0.009)\end{array}$ & 0.65 \\
\hline LIQID & $\begin{array}{c}0.00 \\
(0.003)\end{array}$ & 1.50 & $\begin{array}{c}0.00 * * * \\
(0.000)\end{array}$ & 11.38 & $\begin{array}{c}0.00^{* * * *} \\
(0.000)\end{array}$ & 11.66 & $\begin{array}{c}0.00 * * * \\
(0.000)\end{array}$ & 11.51 \\
\hline LOSS & $\begin{array}{c}-0.74 * * * \\
(0.187)\end{array}$ & -3.94 & $\begin{array}{c}0.03 \\
(0.017)\end{array}$ & 1.56 & $\begin{array}{c}0.03 \\
(0.017)\end{array}$ & 1.52 & $\begin{array}{c}0.03 \\
(0.017)\end{array}$ & 1.54 \\
\hline INVREC & $\begin{array}{c}-0.51 \\
(0.426)\end{array}$ & -1.20 & $\begin{array}{c}0.03 \\
(0.033)\end{array}$ & 0.90 & $\begin{array}{c}0.03 \\
(0.033)\end{array}$ & 0.88 & $\begin{array}{c}0.03 \\
(0.033)\end{array}$ & 0.90 \\
\hline
\end{tabular}




\begin{tabular}{|c|c|c|c|c|c|c|c|c|}
\hline \multirow{2}{*}{ VARIABLES } & \multicolumn{2}{|c|}{$\begin{array}{c}\begin{array}{c}\text { Healy }(1985) \\
\text { model }\end{array} \\
\end{array}$} & \multicolumn{2}{|c|}{$\begin{array}{c}\begin{array}{c}\text { Original Jones (1991) } \\
\text { model }\end{array} \\
\end{array}$} & \multicolumn{2}{|c|}{$\begin{array}{c}\text { Amended Jones (1991) model by } \\
\text { Kothari et al. (2005) }\end{array}$} & \multicolumn{2}{|c|}{$\begin{array}{l}\text { Modified Jones (1991) } \\
\text { model by Dechow (1995) }\end{array}$} \\
\hline & $\begin{array}{l}\text { Coefficient/ } \\
\text { Standard Error }\end{array}$ & $\mathrm{t}$ & $\begin{array}{l}\text { Coefficient/ } \\
\text { Standard Error }\end{array}$ & $\mathrm{t}$ & $\begin{array}{c}\text { Coefficient/ } \\
\text { Standard Error }\end{array}$ & $\mathrm{t}$ & $\begin{array}{c}\text { Coefficient/ } \\
\text { Standard Error }\end{array}$ & $\mathrm{t}$ \\
\hline BTM & $\begin{array}{c}0.01 \\
(0.006)\end{array}$ & 1.31 & $\begin{array}{c}-0.00 * * * \\
(0.000)\end{array}$ & -2.74 & $\begin{array}{c}-0.00 * * * \\
(0.000)\end{array}$ & -2.81 & $\begin{array}{c}-0.00 * * * \\
(0.000)\end{array}$ & -2.77 \\
\hline SUB & $\begin{array}{c}0.43 * * * \\
(0.083)\end{array}$ & 5.13 & $\begin{array}{c}-0.03 * * * \\
(0.007)\end{array}$ & -4.32 & $\begin{array}{c}-0.03 * * * \\
(0.007)\end{array}$ & -4.31 & $\begin{array}{c}-0.03 * * * \\
(0.007)\end{array}$ & -4.33 \\
\hline FOREIGN & $\begin{array}{c}-0.03 \\
(0.087)\end{array}$ & -0.38 & $\begin{array}{l}0.02 * * \\
(0.007)\end{array}$ & 2.47 & $\begin{array}{l}0.02 * * \\
(0.007)\end{array}$ & 2.46 & $\begin{array}{l}0.02 * * \\
(0.007)\end{array}$ & 2.48 \\
\hline CREV & $\begin{array}{l}-0.00 * \\
(0.000)\end{array}$ & -1.68 & $\begin{array}{c}0.00 * * * \\
(0.000)\end{array}$ & 15.04 & $\begin{array}{l}0.00^{* * *} \\
(0.000)\end{array}$ & 15.16 & $\begin{array}{l}0.00 * * * \\
(0.000)\end{array}$ & 15.09 \\
\hline VOL_IFRS & $\begin{array}{l}0.34 * * \\
(0.155)\end{array}$ & 2.17 & $\begin{array}{l}0.04 * * \\
(0.015)\end{array}$ & 2.51 & $\begin{array}{l}0.04 * * \\
(0.015)\end{array}$ & 2.45 & $\begin{array}{l}0.04 * * \\
(0.015)\end{array}$ & 2.50 \\
\hline EMI & $\begin{array}{c}0.13 \\
(0.213)\end{array}$ & 0.59 & $\begin{array}{c}0.04^{*} \\
(0.025)\end{array}$ & 1.69 & $\begin{array}{c}0.04 * \\
(0.025)\end{array}$ & 1.67 & $\begin{array}{c}0.04^{*} \\
(0.025)\end{array}$ & 1.65 \\
\hline LNTACC & N/A & N/A & $\begin{array}{c}0.02 * * * \\
(0.004)\end{array}$ & 5.77 & $\begin{array}{c}0.03 * * * \\
(0.004)\end{array}$ & 5.76 & $\begin{array}{c}0.03 * * * \\
(0.004)\end{array}$ & 5.77 \\
\hline Constant & $\begin{array}{l}5.92 * * * \\
(0.386)\end{array}$ & 15.32 & $\begin{array}{c}-0.00 \\
(0.042)\end{array}$ & $\begin{array}{l}-0.05 \\
-3.09\end{array}$ & $\begin{array}{c}-0.00 \\
(0.042)\end{array}$ & -0.06 & $\begin{array}{l}-0.00 \\
(0.042)\end{array}$ & -0.07 \\
\hline Observations & 567 & & 567 & & 567 & & 567 & \\
\hline R-squared & 0.38 & & 0.29 & & 0.29 & & 0.29 & \\
\hline Adj. R-squared & 0.36 & & 0.27 & & 0.27 & & 0.27 & \\
\hline
\end{tabular}




\subsubsection{Tests for Audit Fee Model}

\subsubsection{Heteroscedasticity Robust Option}

In order to mitigate econometric issues associated with heteroscedastic error terms, I also applied the White (1980) adjustment procedure to all regression models summarised in section 6.2.2. Here, Table 6.12 provides a brief comparison between the t-scores obtained under the standard OLS regression assumptions and the tscores based on the White (1980) adjustment procedure.

Table 6.12 shows that there are significant changes in some of the t-scores under the White (1980) adjustment procedure. For example, the BTM variable returns a marginally significant $\mathrm{t}$-score under standard OLS assumptions but the t-score for this variable becomes insignificant at all conventional levels under the White (1980) adjustment procedure. This contrasts with the DACC_1 variable which returns only a marginally significant $\mathrm{t}$-score under standard OLS assumptions but a highly significant t-score when the White (1980) adjustment procedure is applied. 
Table 6.12: A Comparison between Standard OLS Regression Results and OLS with the White (1980) Adjustment Procedure for Audit Fee Tests

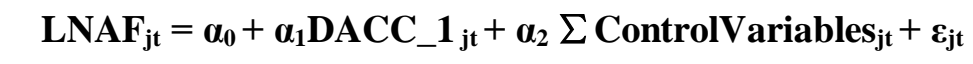

\begin{tabular}{|c|c|c|c|c|}
\hline \multirow[b]{2}{*}{ VARIABLES } & \multicolumn{2}{|c|}{ OLS Regression } & \multicolumn{2}{|c|}{ OLS Regression with robust } \\
\hline & $\begin{array}{c}\text { Coefficient/ } \\
\text { Standard Error }\end{array}$ & $\mathrm{t}$ & $\begin{array}{c}\text { Coefficient/ } \\
\text { Standard Error }\end{array}$ & $\mathrm{T}$ \\
\hline DACC_1 & $\begin{array}{l}0.18 * * \\
(0.088)\end{array}$ & 2.08 & $\begin{array}{c}0.18 * * * \\
(0.065)\end{array}$ & 2.81 \\
\hline BIG4 & $\begin{array}{l}0.15^{* *} \\
(0.060)\end{array}$ & 2.55 & $\begin{array}{l}0.15^{* *} \\
(0.071)\end{array}$ & 2.16 \\
\hline AOFFICE & $\begin{array}{c}0.32 * * * \\
(0.054)\end{array}$ & 5.90 & $\begin{array}{c}0.32 * * * \\
(0.055)\end{array}$ & 5.77 \\
\hline FISCAL & $\begin{array}{c}0.04 \\
(0.050)\end{array}$ & 0.86 & $\begin{array}{c}0.04 \\
(0.049)\end{array}$ & 0.88 \\
\hline C_AUDITOR & $\begin{array}{l}-0.24 * * \\
(0.111)\end{array}$ & -2.20 & $\begin{array}{c}-0.24 * * * \\
(0.094)\end{array}$ & -2.61 \\
\hline $\mathrm{AO}$ & $\begin{array}{c}0.28 * * * \\
(0.066)\end{array}$ & 4.32 & $\begin{array}{c}0.28 * * * \\
(0.069)\end{array}$ & 4.12 \\
\hline LNTA & $\begin{array}{c}0.35^{* * *} \\
(0.013)\end{array}$ & 26.33 & $\begin{array}{c}0.35^{* * *} \\
(0.014)\end{array}$ & 24.39 \\
\hline LEVE & $\begin{array}{c}0.19 * * * \\
(0.042)\end{array}$ & 4.46 & $\begin{array}{c}0.19 * * * \\
(0.069)\end{array}$ & 2.74 \\
\hline LIQID & $\begin{array}{l}-0.00 * * \\
(0.001)\end{array}$ & -1.99 & $\begin{array}{l}-0.00 * \\
(0.001)\end{array}$ & -1.83 \\
\hline BTM & $\begin{array}{c}0.00^{*} \\
(0.001)\end{array}$ & 1.69 & $\begin{array}{c}0.00 \\
(0.001)\end{array}$ & 1.49 \\
\hline INVREC & $\begin{array}{c}0.84 * * * \\
(0.104)\end{array}$ & 8.06 & $\begin{array}{c}0.84 * * * \\
(0.114)\end{array}$ & 7.38 \\
\hline SUB & $\begin{array}{c}0.13^{* * * *} \\
(0.021)\end{array}$ & 6.45 & $\begin{array}{c}0.13^{* * * *} \\
(0.022)\end{array}$ & 6.12 \\
\hline FOREIGN & $\begin{array}{c}0.25^{* * * *} \\
(0.023)\end{array}$ & 11.12 & $\begin{array}{c}0.25^{* * * *} \\
(0.024)\end{array}$ & 10.47 \\
\hline CREV & $\begin{array}{c}0.00^{*} \\
(0.000)\end{array}$ & 1.71 & $\begin{array}{l}0.00 * * \\
(0.000)\end{array}$ & 2.09 \\
\hline VOL_IFRS & $\begin{array}{c}0.22 * * * \\
(0.044)\end{array}$ & 5.06 & $\begin{array}{c}0.22 * * * \\
(0.044)\end{array}$ & 5.06 \\
\hline EMI & $\begin{array}{l}0.12 * * \\
(0.058)\end{array}$ & 2.01 & $\begin{array}{l}0.12 * * \\
(0.052)\end{array}$ & 2.26 \\
\hline Constant & $\begin{array}{c}-0.77 * * * \\
(0.150)\end{array}$ & -5.12 & $\begin{array}{c}-0.77 * * * \\
(0.154)\end{array}$ & -4.99 \\
\hline $\begin{array}{c}\text { Observations } \\
\text { R-squared } \\
\text { Adj. R-squared }\end{array}$ & $\begin{array}{c}567 \\
0.84 \\
0.84 \\
\end{array}$ & & $\begin{array}{l}567 \\
0.84 \\
0.84 \\
\end{array}$ & \\
\hline & $\begin{array}{l}\text { Standard } \\
* * * \mathrm{p}<0.01\end{array}$ & $\begin{array}{l}1 \text { pare } \\
0.05 \text {, }\end{array}$ & & \\
\hline
\end{tabular}




\subsubsection{Multicolinearity Tests}

As in Section 6.3.1.2, I use the variance inflation factor (VIF) and the Condition Index Test to check for issues of multicolinearity that might arise with my audit fee regression model. Here Table 6.13 shows that all the variance inflation factors (VIF) associated with my regression outputs are well within the limit of 3 above which, a regression procedure is considered to be affected by problems of co-linear independent variables (O’Brien 2007).

Furthermore, the Condition Index Test based on the eigenvalues of the matrix of correlation coefficients between the independent variables ${ }^{13}$ as summarised in Table 6.14 , is below the limit of thirty at which issues of multicolinearity are considered to arise (Belsley et al., 1980). Hence, there is no evidence that the parameter estimates and their associated t-scores obtained from my audit fee regression model are affected by issues of co-linear independent variables.

Table 6.13: Variance Inflation Factors for Audit Fee Model

\begin{tabular}{|c|c|c|c|c|}
\hline Variable & VIF & SQRT-VIF & Tolerance & R-Squared \\
\hline DACC_1 & 1.09 & 1.04 & 0.9167 & 0.08 \\
\hline BIG4 & 1.33 & 1.15 & 0.7541 & 0.25 \\
\hline AOFFICE & 1.11 & 1.05 & 0.9045 & 0.10 \\
\hline FISCAL & 1.03 & 1.02 & 0.9679 & 0.03 \\
\hline C_AUDITOR & 1.11 & 1.05 & 0.9044 & 0.10 \\
\hline AO & 1.23 & 1.11 & 0.8148 & 0.19 \\
\hline LNTA & 1.96 & 1.4 & 0.5102 & 0.49 \\
\hline LEVE & 1.19 & 1.09 & 0.8372 & 0.16 \\
\hline LIQID & 1.05 & 1.02 & 0.9552 & 0.04 \\
\hline BTM & 1.18 & 1.09 & 0.8481 & 0.15 \\
\hline INVREC & 1.17 & 1.08 & 0.8517 & 0.15 \\
\hline SUB & 2.32 & 1.52 & 0.4312 & 0.57 \\
\hline FOREIGN & 2.03 & 1.42 & 0.4935 & 0.51 \\
\hline CREV & 1.06 & 1.03 & 0.9449 & 0.06 \\
\hline VOL_IFRS & 1.08 & 1.04 & 0.9222 & 0.08 \\
\hline EMI & 1.06 & 1.03 & 0.9469 & 0.05 \\
\hline Mean VIF & $\mathbf{1 . 3 1}$ & & & \\
\hline
\end{tabular}

\footnotetext{
${ }^{13}$ The matrix of correlation coefficients between the independent variables is to be found in Table 6.3 .
} 
Table 6.14: Condition Number Test for Audit Fee Model

\begin{tabular}{|c|c|c|}
\hline No & Eigenvalue & Condition Index \\
\hline 1 & 8.0060 & 1.0000 \\
\hline 2 & 1.3209 & 2.4619 \\
\hline 3 & 1.1325 & 2.6588 \\
\hline 4 & 1.0174 & 2.8051 \\
\hline 5 & 0.8600 & 3.0510 \\
\hline 6 & 0.7850 & 3.1935 \\
\hline 7 & 0.7723 & 3.2197 \\
\hline 8 & 0.6786 & 3.4348 \\
\hline 9 & 0.5927 & 3.6751 \\
\hline 10 & 0.5178 & 3.9319 \\
\hline 11 & 0.3916 & 4.5216 \\
\hline 12 & 0.3423 & 4.8362 \\
\hline 13 & 0.2171 & 6.0727 \\
\hline 14 & 0.1863 & 6.5558 \\
\hline 15 & 0.1229 & 8.0703 \\
\hline 16 & 0.0464 & 13.1317 \\
\hline 17 & 0.0101 & 28.1077 \\
\hline Condition Number & & $\mathbf{2 8 . 1 0 7 7}$ \\
\hline
\end{tabular}

\subsubsection{Current Year versus Previous Year Tests}

The manner in which the level of earnings management will impact on the audit fee in the same year rather than the audit fee in the next ensuring year has been examined by Gul et al. (2003) and Abbott et al. (2006) and has been summarised in detail in section 2.3 of this thesis. Gul et al. (2003), for example, find a significant relationship between audit fees and discretionary accruals for Australian data and hypothesise that this relationship is driven by incentives arising out of the managerial compensation schemes employed by Australian firms. To test this hypothesis for the New Zealand data on which my analysis is based, I incorporate the absolute level of discretionary accruals (that is, DACCs) in the current year into the amended version of the Simunic (1980) regression model as given by equation (1) in section 5.3.1. The empirical evidence, as summarized in the first two panels 
of Table 6.15, shows that audit fees are insignificantly associated with the level of discretionary accruals in the current year (the DACC variable). For completeness the third panel of Table 6.15 duplicates my main test results as summarized in Table 6.5 of section 6.2 .2 and when taken in conjunction with the second panel of Table 6.15 shows that the level of discrestionary accruals in the previous year is positively and significantly associated with the level of the audit fee in the current year (the DACC_1 variable).

Hence, in summary, my empirical results are compatible with the hypothesis that the level of the audit fee paid for a particular audit client is influenced by the level of discretionary accruals for the given audit client in the previous year rather than the level of discretionary accruals in the current year. 
Table 6.15: The Impact of the Level of Discretionary Accruals in Current Year versus Previous Year on the Level of the Audit Fee

$$
\mathrm{LNAF}_{\mathrm{jt}}=\alpha_{0}+\alpha_{11} \mathrm{DACC}_{-} 1_{\mathrm{jt}}+\left[\alpha_{12} \mathrm{DACC}_{\mathrm{jt}}\right]+\alpha_{2} \sum \text { ControlVariables }_{\mathrm{jt}}+\varepsilon_{\mathrm{jt}}
$$

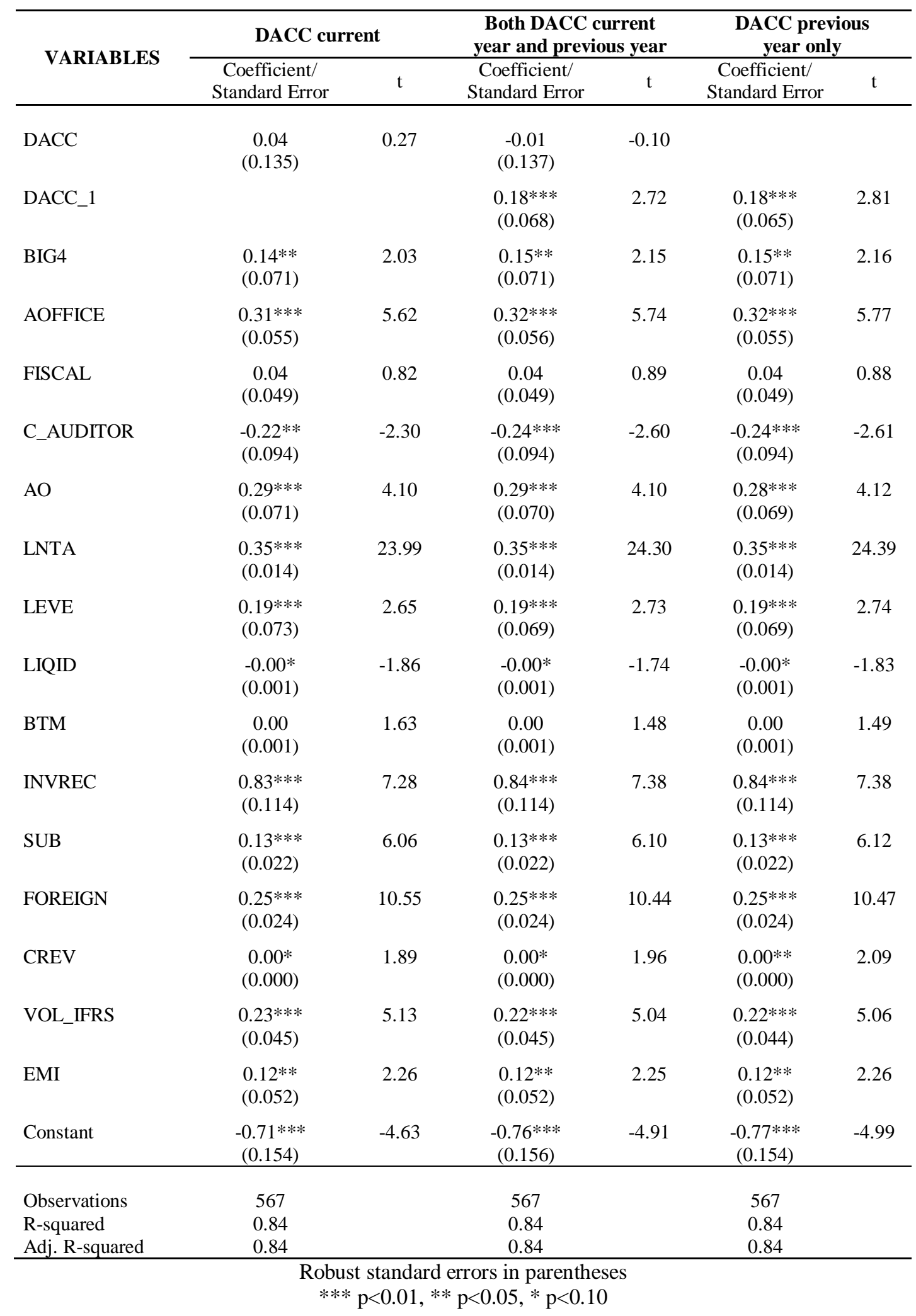




\subsubsection{OLS Regression with Cluster Option}

It is possible that the level of discretionary accruals among different firms within a year or different years within a firm may not be independent, and this could lead to residuals that are not independent within years or firms. I therefore use OLS regression with the cluster option (by firm and year) in order to address this issue. Table 6.16 provides the results for the two cluster regressions; namely, by firm (based on a sample of 142 firms) and by year (based on a sample of 5 years) as well the OLS regression results without the cluster option. ${ }^{14}$

Overall, the results regarding the relationship between the level of DACCs in the previous year (DACC_1) and the audit fee in current year (LNAF) remain unchanged when the cluster regression procedure is applied. In particular, Table 6.16 shows that the level of DACCs from the previous year (that is DACC_1) is significantly associated with the level of the audit fee (LNAF) in the current year at the 1 percentage point level of significance. There are, however, some changes in significance levels for some of the control variables. For example, the t-score associated with the coefficient of the BIG4 variable becomes insignificant in the cluster regression based on my sample of 142 firms and the cluster regression based on my 5 years' of sample data. Similarly, the t-score associated with the coefficient of the CREV variable becomes insignificant in the cluster regression based on my 5 years' of sample data.

\footnotetext{
14 I again emphasise (as in footnote 8) that all $\mathrm{t}$ statistics for the cluster regression based on the sample of 142 firms have $v=141$ degrees of freedom. All statistics for the cluster regression based on the sample of 5 years have $v=4$ degrees of freedom (StataCorp 2013, p. 312).
} 
Table 6.16: Testing the Relationship between the Level of Discretionary Accruals and the Level of the Audit Fee in the Next year with the Cluster Option by Firms and Years

$$
\text { LNAF }_{\mathrm{jt}}=\alpha_{0}+\alpha_{1}{\text { DACC__ } 11_{j t}+\alpha_{2} \sum \text { ControlVariables }}_{j t}+\varepsilon_{j t}
$$

\begin{tabular}{|c|c|c|c|c|c|c|}
\hline \multirow{2}{*}{ VARIABLES } & \multicolumn{2}{|c|}{$\begin{array}{c}\text { Adjusted for } \\
142 \text { clusters in Firm }\end{array}$} & \multicolumn{2}{|c|}{$\begin{array}{c}\text { Adjusted for } \\
5 \text { clusters in Year }\end{array}$} & \multicolumn{2}{|c|}{$\begin{array}{c}\text { OLS regression } \\
\text { (presented in section 6.2.2) }\end{array}$} \\
\hline & $\begin{array}{l}\text { Coefficient/ } \\
\text { Standard Error }\end{array}$ & $\mathrm{t}$ & $\begin{array}{l}\text { Coefficient/ } \\
\text { Standard Error }\end{array}$ & $\mathrm{t}$ & $\begin{array}{c}\text { Coefficient/ } \\
\text { Standard Error }\end{array}$ & $\mathrm{t}$ \\
\hline DACC_1 & $\begin{array}{c}0.18^{* * * *} \\
(0.067)\end{array}$ & 2.74 & $\begin{array}{l}0.18^{* * * *} \\
(0.038)\end{array}$ & 4.82 & $\begin{array}{l}0.18 * * * \\
(0.065)\end{array}$ & 2.81 \\
\hline BIG4 & $\begin{array}{c}0.15 \\
(0.120)\end{array}$ & 1.28 & $\begin{array}{c}0.15 \\
(0.097)\end{array}$ & 1.57 & $\begin{array}{l}0.15^{* *} \\
(0.071)\end{array}$ & 2.16 \\
\hline AOFFICE & $\begin{array}{c}0.32 * * * \\
(0.083)\end{array}$ & 3.84 & $\begin{array}{l}0.32 * * * \\
(0.022)\end{array}$ & 14.73 & $\begin{array}{c}0.32 * * * \\
(0.055)\end{array}$ & 5.77 \\
\hline FISCAL & $\begin{array}{c}0.04 \\
(0.085)\end{array}$ & 0.51 & $\begin{array}{c}0.04 \\
(0.039)\end{array}$ & 1.11 & $\begin{array}{c}0.04 \\
(0.049)\end{array}$ & 0.88 \\
\hline C_AUDITOR & $\begin{array}{l}-0.24 * * \\
(0.097)\end{array}$ & -2.51 & $\begin{array}{l}-0.24 * * \\
(0.086)\end{array}$ & -2.85 & $\begin{array}{c}-0.24 * * * \\
(0.094)\end{array}$ & -2.61 \\
\hline $\mathrm{AO}$ & $\begin{array}{c}0.28 * * * \\
(0.097)\end{array}$ & 2.92 & $\begin{array}{c}0.28 * * * \\
(0.031)\end{array}$ & 9.08 & $\begin{array}{l}0.28 * * * \\
(0.069)\end{array}$ & 4.12 \\
\hline LNTA & $\begin{array}{c}0.35 * * * \\
(0.024)\end{array}$ & 14.58 & $\begin{array}{l}0.35 * * * \\
(0.008)\end{array}$ & 42.92 & $\begin{array}{l}0.35 * * * \\
(0.014)\end{array}$ & 24.39 \\
\hline LEVE & $\begin{array}{l}0.19 * * \\
(0.074)\end{array}$ & 2.55 & $\begin{array}{c}0.19^{*} \\
(0.072)\end{array}$ & 2.61 & $\begin{array}{l}0.19 * * * \\
(0.069)\end{array}$ & 2.74 \\
\hline LIQID & $\begin{array}{l}-0.00 * \\
(0.001)\end{array}$ & -1.78 & $\begin{array}{c}-0.00 \\
(0.001)\end{array}$ & -2.03 & $\begin{array}{l}-0.00 * \\
(0.001)\end{array}$ & -1.83 \\
\hline BTM & $\begin{array}{c}0.00 \\
(0.002)\end{array}$ & 1.35 & $\begin{array}{c}0.00 \\
(0.002)\end{array}$ & 1.02 & $\begin{array}{c}0.00 \\
(0.001)\end{array}$ & 1.49 \\
\hline INVREC & $\begin{array}{c}0.84 * * * \\
(0.185)\end{array}$ & 4.54 & $\begin{array}{l}0.84 * * * \\
(0.075)\end{array}$ & 11.27 & $\begin{array}{c}0.84 * * * \\
(0.114)\end{array}$ & 7.38 \\
\hline SUB & $\begin{array}{c}0.13 * * * \\
(0.039)\end{array}$ & 3.37 & $\begin{array}{l}0.13 * * * \\
(0.013)\end{array}$ & 10.20 & $\begin{array}{l}0.13 * * * \\
(0.022)\end{array}$ & 6.12 \\
\hline FOREIGN & $\begin{array}{l}0.25^{* * *} \\
(0.043)\end{array}$ & 5.84 & $\begin{array}{l}0.25 * * * \\
(0.013)\end{array}$ & 19.48 & $\begin{array}{l}0.25^{* * *} \\
(0.024)\end{array}$ & 10.47 \\
\hline CREV & $\begin{array}{l}0.00 * * \\
(0.000)\end{array}$ & 2.22 & $\begin{array}{c}0.00 \\
(0.000)\end{array}$ & 2.12 & $\begin{array}{l}0.00 * * \\
(0.000)\end{array}$ & 2.09 \\
\hline VOL_IFRS & $\begin{array}{c}0.22 * * * \\
(0.080)\end{array}$ & 2.82 & $\begin{array}{c}0.22 * * * \\
(0.044)\end{array}$ & 5.08 & $\begin{array}{c}0.22 * * * \\
(0.044)\end{array}$ & 5.06 \\
\hline EMI & $\begin{array}{l}0.12 * * \\
(0.054)\end{array}$ & 2.15 & $\begin{array}{l}0.12 * * \\
(0.039)\end{array}$ & 3.01 & $\begin{array}{l}0.12 * * \\
(0.052)\end{array}$ & 2.26 \\
\hline Constant & $\begin{array}{c}-0.77 * * * \\
(0.248)\end{array}$ & -3.09 & $\begin{array}{c}-0.77 * * * \\
(0.099) \\
\end{array}$ & -7.74 & $\begin{array}{c}-0.77 * * * \\
(0.154) \\
\end{array}$ & -4.99 \\
\hline Observations & 567 & & 567 & & 567 & \\
\hline R-squared & 0.84 & & 0.84 & & 0.84 & \\
\hline Adj. R-squared & 0.84 & & 0.84 & & 0.84 & \\
\hline
\end{tabular}




\subsubsection{Regression with Measurement Error}

As in Section 6.3.1.4, I also use the "eivreg regression" option in the STATA software package to make allowances for potential measurement errors when estimating the coefficients for the audit fee regression model. Here, Table 6.17 provides summary details of the changes that occur between the audit fee regression model based on standard OLS procedures and the OLS procedures with the inclusion of the "eivreg regression" option.

As can be seen from Table 6.17, the level of DACCs in the previous year (the DACC_1 variable) is positively and significantly associated with the level of the audit fee (LNAF) in the current year - although the level of significance declines from $1 \%$ under standard OLS procedures to $5 \%$ when the OLS procedure with the "eivreg regression" option is applied. Moreover, there are only a few minor differences for other parameter estimates and their associated t-scores under the two regression procedures. For example, the t-score associated with the coefficient of the book to market ratio (the BTM variable) increases from a statistically insignificant 1.49 under standard OLS regression procedures to a marginally significant 1.69 under the OLS procedure with the inclusion of the "eivreg regression" option. This in turn means that there is a marginally statistically significant relationship between the book to market ratio and the level of the audit fee under the OLS procedure with the "eivreg regression" option. 
Table 6.17: Regression Results with "eivreg regression" Option for Audit Fees Model

$$
\text { LNAF }_{j t}=\alpha_{0}+\alpha_{1} \text { DACC__ }_{j_{\mathrm{jt}}}+\alpha_{2} \sum \text { ControlVariables }_{\mathrm{jt}}+\varepsilon_{\mathrm{jt}}
$$

\begin{tabular}{|c|c|c|c|c|}
\hline \multirow{2}{*}{ VARIABLES } & \multicolumn{2}{|c|}{$\begin{array}{l}\text { OLS Regression with } \\
\text { "eivreg regression" option }\end{array}$} & \multicolumn{2}{|c|}{ Standard OLS Regression Results } \\
\hline & $\begin{array}{c}\text { Coefficient/ } \\
\text { Standard Error }\end{array}$ & $\mathrm{t}$ & $\begin{array}{c}\text { Coefficient/ } \\
\text { Standard Error }\end{array}$ & $\mathrm{T}$ \\
\hline DACC_1 & $\begin{array}{l}0.18 * * \\
(0.088)\end{array}$ & 2.08 & $\begin{array}{c}0.18 * * * \\
(0.065)\end{array}$ & 2.81 \\
\hline BIG4 & $\begin{array}{l}0.15^{* *} \\
(0.060)\end{array}$ & 2.55 & $\begin{array}{l}0.15^{* *} \\
(0.071)\end{array}$ & 2.16 \\
\hline AOFFICE & $\begin{array}{c}0.32 * * * \\
(0.054)\end{array}$ & 5.90 & $\begin{array}{c}0.32 * * * \\
(0.055)\end{array}$ & 5.77 \\
\hline FISCAL & $\begin{array}{c}0.04 \\
(0.050)\end{array}$ & 0.86 & $\begin{array}{c}0.04 \\
(0.049)\end{array}$ & 0.88 \\
\hline C_AUDITOR & $\begin{array}{c}-0.24 * * \\
(0.111)\end{array}$ & -2.20 & $\begin{array}{c}-0.24 * * * \\
(0.094)\end{array}$ & -2.61 \\
\hline $\mathrm{AO}$ & $\begin{array}{c}0.28 * * * \\
(0.066)\end{array}$ & 4.32 & $\begin{array}{c}0.28 * * * \\
(0.069)\end{array}$ & 4.12 \\
\hline LNTA & $\begin{array}{c}0.35^{* * *} \\
(0.013)\end{array}$ & 26.33 & $\begin{array}{l}0.35^{* * * *} \\
(0.014)\end{array}$ & 24.39 \\
\hline LEVE & $\begin{array}{c}0.19 * * * \\
(0.042)\end{array}$ & 4.46 & $\begin{array}{c}0.19 * * * \\
(0.069)\end{array}$ & 2.74 \\
\hline LIQID & $\begin{array}{l}-0.00^{* *} \\
(0.001)\end{array}$ & -1.99 & $\begin{array}{l}-0.00^{*} \\
(0.001)\end{array}$ & -1.83 \\
\hline BTM & $\begin{array}{c}0.00 * \\
(0.001)\end{array}$ & 1.69 & $\begin{array}{c}0.00 \\
(0.001)\end{array}$ & 1.49 \\
\hline INVREC & $\begin{array}{c}0.84 * * * \\
(0.104)\end{array}$ & 8.06 & $\begin{array}{c}0.84 * * * \\
(0.114)\end{array}$ & 7.38 \\
\hline SUB & $\begin{array}{c}0.13^{* * * *} \\
(0.021)\end{array}$ & 6.45 & $\begin{array}{c}0.13 * * * \\
(0.022)\end{array}$ & 6.12 \\
\hline FOREIGN & $\begin{array}{c}0.25 * * * \\
(0.023)\end{array}$ & 11.12 & $\begin{array}{c}0.25 * * * \\
(0.024)\end{array}$ & 10.47 \\
\hline CREV & $\begin{array}{c}0.00 * \\
(0.000)\end{array}$ & 1.71 & $\begin{array}{l}0.00 * * \\
(0.000)\end{array}$ & 2.09 \\
\hline VOL_IFRS & $\begin{array}{c}0.22 * * * \\
(0.044)\end{array}$ & 5.06 & $\begin{array}{c}0.22 * * * \\
(0.044)\end{array}$ & 5.06 \\
\hline EMI & $\begin{array}{l}0.12 * * \\
(0.058)\end{array}$ & 2.01 & $\begin{array}{l}0.12 * * \\
(0.052)\end{array}$ & 2.26 \\
\hline Constant & $\begin{array}{c}-0.77 * * * \\
(0.150) \\
\end{array}$ & -5.12 & $\begin{array}{c}-0.77 * * * \\
(0.154) \\
\end{array}$ & -4.99 \\
\hline Observations & 567 & & 567 & \\
\hline R-squared & 0.84 & & 0.84 & \\
\hline Adj. R-squared & . & & 0.84 & \\
\hline
\end{tabular}




\subsubsection{Different Measurements of Discretionary Accruals}

I also test the robustness of my results by using three alternative measures of discretionary accruals; namely, the Healy (1985) model, the original Jones (1991) model and the amended specification of the modified Jones (1991) model as developed by Kothari et al. (2005) ${ }^{15}$. The empirical results obtained for the modified Jones (1991) model as summarised in Table 6.5 (as in section 6.2.2) and reproduced in panel 4 of Table 6.18, are virtually indistinguishable from the empirical results summarised in panels two and three of Table 6.18 for the original Jones (1991) model and the Kothari et al. (2005) specification for the amended Jones (1991) model. In particular, all three models [that is, the original Jones (1991), the modified Jones (1991) and the Kothari et al. (2005) specification for the amended Jones (1991) model] indicate that the level of DACCs in the previous year (that is the DACC_1 variable) is significantly associated with the level of the audit fee in current year (LNAF) at the $1 \%$ significance level. However, panel one of Table 6.18 also shows that the t-score of 2.81 associated with the discretionary accruals variable for the previous year (DACC_1) as calculated by the modified Jones (1991) model, decreases slightly to 2.38 when the discretionary accruals are based on the Healy (1985) model. This in turn leads to a change of the significance level of my regression from 1\% under the Modified Jones (1991) model to 5\% under the Healy (1985) model. As previously noted (in section 6.3.1.5), this less compelling result for the Healy (1985) model may be driven by the fact that total accruals are an intervening variable for factors such as business strategy, industry conventions, macro-economic events and other economic factors (Ronen and Yaari 2007). This in turn will mean that the Healy (1985) model will provide an inefficient specification of the relationship between the level of DACCs and audit fees.

\footnotetext{
${ }^{15}$ The Healy (1985) model and original Jones (1991) model of the accruals process as well as the modified Jones (1991) model are summarised in section 2.1.4 in this thesis.
} 
Table 6.18: Testing the Relationship between the Level of Discretionary Accruals (DACCs) and the Level of the Audit Fee in the Next Year using Different Measures of Discretionary Accruals

$$
\mathbf{L N A F}_{\mathrm{jt}}=\alpha_{0}+\alpha_{1} \text { DACC_ }_{-} \mathbf{1}_{\mathrm{jt}}+\alpha_{2} \sum \text { ControlVariables }_{\mathrm{jt}}+\varepsilon_{\mathrm{jt}}
$$

\begin{tabular}{|c|c|c|c|c|c|c|c|c|}
\hline \multirow{2}{*}{ VARIABLES } & \multicolumn{2}{|c|}{$\begin{array}{l}\text { Healy }(1985) \\
\text { model }\end{array}$} & \multicolumn{2}{|c|}{$\begin{array}{l}\text { Original Jones } \\
\text { (1991) }\end{array}$} & \multicolumn{2}{|c|}{$\begin{array}{c}\text { Amended specification } \\
\text { of the modified Jones } \\
\text { (1991) }\end{array}$} & \multicolumn{2}{|c|}{$\begin{array}{l}\text { Modified Jones } \\
\text { (1991) }\end{array}$} \\
\hline & $\begin{array}{c}\text { Coefficient/ } \\
\text { Standard } \\
\text { Error } \\
\end{array}$ & $\mathrm{t}$ & $\begin{array}{c}\text { Coefficient/ } \\
\text { Standard } \\
\text { Error } \\
\end{array}$ & $\mathrm{t}$ & $\begin{array}{c}\text { Coefficient/ } \\
\text { Standard } \\
\text { Error } \\
\end{array}$ & $\mathrm{t}$ & $\begin{array}{c}\text { Coefficient/ } \\
\text { Standard } \\
\text { Error } \\
\end{array}$ & $\mathrm{t}$ \\
\hline DACC_1 & $\begin{array}{l}0.04 * * \\
(0.017)\end{array}$ & 2.38 & $\begin{array}{c}0.18^{* * * *} \\
(0.065)\end{array}$ & 2.84 & $\begin{array}{c}0.18^{* * * *} \\
(0.065)\end{array}$ & 2.82 & $\begin{array}{c}0.18^{* * * *} \\
(0.065)\end{array}$ & 2.81 \\
\hline BIG4 & $\begin{array}{c}0.14^{*} \\
(0.071)\end{array}$ & 1.96 & $\begin{array}{l}0.15^{* *} \\
(0.071)\end{array}$ & 2.16 & $\begin{array}{l}0.15^{* *} \\
(0.071)\end{array}$ & 2.16 & $\begin{array}{l}0.15 * * \\
(0.071)\end{array}$ & 2.16 \\
\hline AOFFICE & $\begin{array}{c}0.31 * * * \\
(0.054)\end{array}$ & 5.73 & $\begin{array}{c}0.32 * * * \\
(0.055)\end{array}$ & 5.77 & $\begin{array}{c}0.32 * * * \\
(0.055)\end{array}$ & 5.77 & $\begin{array}{c}0.32 * * * \\
(0.055)\end{array}$ & 5.77 \\
\hline FISCAL & $\begin{array}{c}0.05 \\
(0.049)\end{array}$ & 1.02 & $\begin{array}{c}0.04 \\
(0.049)\end{array}$ & 0.88 & $\begin{array}{c}0.04 \\
(0.049)\end{array}$ & 0.88 & $\begin{array}{c}0.04 \\
(0.049)\end{array}$ & 0.88 \\
\hline C_AUDITOR & $\begin{array}{c}-0.23 * * \\
(0.092)\end{array}$ & -2.46 & $\begin{array}{c}-0.25 * * * \\
(0.094)\end{array}$ & -2.62 & $\begin{array}{c}-0.24 * * * \\
(0.094)\end{array}$ & -2.61 & $\begin{array}{c}-0.24 * * * \\
(0.094)\end{array}$ & -2.61 \\
\hline $\mathrm{AO}$ & $\begin{array}{c}0.27 * * * \\
(0.068)\end{array}$ & 3.91 & $\begin{array}{c}0.28 * * * \\
(0.069)\end{array}$ & 4.12 & $\begin{array}{c}0.28 * * * \\
(0.069)\end{array}$ & 4.12 & $\begin{array}{c}0.28 * * * \\
(0.069)\end{array}$ & 4.12 \\
\hline LNTA & $\begin{array}{c}0.31 * * * \\
(0.019)\end{array}$ & 16.45 & $\begin{array}{c}0.35^{* * * *} \\
(0.014)\end{array}$ & 24.41 & $\begin{array}{c}0.35^{* * *} \\
(0.014)\end{array}$ & 24.40 & $\begin{array}{c}0.35^{* * * *} \\
(0.014)\end{array}$ & 24.39 \\
\hline LEVE & $\begin{array}{l}0.18 * * \\
(0.072)\end{array}$ & 2.56 & $\begin{array}{c}0.19 * * * \\
(0.069)\end{array}$ & 2.75 & $\begin{array}{c}0.19 * * * \\
(0.069)\end{array}$ & 2.75 & $\begin{array}{c}0.19 * * * \\
(0.069)\end{array}$ & 2.74 \\
\hline LIQID & $\begin{array}{c}-0.00 \\
(0.001)\end{array}$ & -1.64 & $\begin{array}{l}-0.00 * \\
(0.001)\end{array}$ & -1.83 & $\begin{array}{l}-0.00^{*} \\
(0.001)\end{array}$ & -1.83 & $\begin{array}{l}-0.00 * \\
(0.001)\end{array}$ & -1.83 \\
\hline BTM & $\begin{array}{c}0.00 \\
(0.001)\end{array}$ & 1.50 & $\begin{array}{c}0.00 \\
(0.001)\end{array}$ & 1.50 & $\begin{array}{c}0.00 \\
(0.001)\end{array}$ & 1.49 & $\begin{array}{c}0.00 \\
(0.001)\end{array}$ & 1.49 \\
\hline INVREC & $\begin{array}{c}0.80 * * * \\
(0.113)\end{array}$ & 7.13 & $\begin{array}{c}0.84 * * * \\
(0.114)\end{array}$ & 7.39 & $\begin{array}{c}0.84 * * * \\
(0.114)\end{array}$ & 7.38 & $\begin{array}{l}0.84 * * * \\
(0.114)\end{array}$ & 7.38 \\
\hline SUB & $\begin{array}{c}0.13 * * * \\
(0.022)\end{array}$ & 6.08 & $\begin{array}{c}0.13 * * * \\
(0.022)\end{array}$ & 6.12 & $\begin{array}{c}0.13 * * * \\
(0.022)\end{array}$ & 6.12 & $\begin{array}{c}0.13 * * * \\
(0.022)\end{array}$ & 6.12 \\
\hline FOREIGN & $\begin{array}{c}0.25 * * * \\
(0.024)\end{array}$ & 10.23 & $\begin{array}{c}0.25 * * * \\
(0.024)\end{array}$ & 10.47 & $\begin{array}{c}0.25 * * * \\
(0.024)\end{array}$ & 10.47 & $\begin{array}{c}0.25 * * * \\
(0.024)\end{array}$ & 10.47 \\
\hline CREV & $\begin{array}{l}0.00 * * \\
(0.000)\end{array}$ & 2.21 & $\begin{array}{l}0.00 * * \\
(0.000)\end{array}$ & 2.09 & $\begin{array}{l}0.00 * * \\
(0.000)\end{array}$ & 2.09 & $\begin{array}{l}0.00 * * \\
(0.000)\end{array}$ & 2.09 \\
\hline VOL_IFRS & $\begin{array}{c}0.21 * * * \\
(0.045)\end{array}$ & 4.67 & $\begin{array}{c}0.22 * * * \\
(0.044)\end{array}$ & 5.06 & $\begin{array}{c}0.22 * * * \\
(0.044)\end{array}$ & 5.06 & $\begin{array}{c}0.22 * * * \\
(0.044)\end{array}$ & 5.06 \\
\hline EMI & $\begin{array}{l}0.11 * * \\
(0.051)\end{array}$ & 2.22 & $\begin{array}{l}0.12 * * \\
(0.052)\end{array}$ & 2.26 & $\begin{array}{l}0.12 * * \\
(0.052)\end{array}$ & 2.26 & $\begin{array}{l}0.12 * * \\
(0.052)\end{array}$ & 2.26 \\
\hline Constant & $\begin{array}{c}-0.66 * * * \\
(0.148) \\
\end{array}$ & -4.46 & $\begin{array}{c}-0.77 * * * \\
(0.153) \\
\end{array}$ & -5.00 & $\begin{array}{c}-0.77 * * * \\
(0.154) \\
\end{array}$ & -4.99 & $\begin{array}{c}-0.77 * * * \\
(0.154) \\
\end{array}$ & -4.99 \\
\hline Observations & 566 & & 567 & & 567 & & 567 & \\
\hline R-squared & 0.84 & & 0.84 & & 0.84 & & 0.84 & \\
\hline Adj. R-squared & 0.84 & & 0.84 & & 0.84 & & 0.84 & \\
\hline
\end{tabular}




\subsection{Conclusion}

Chapter six has summarised the important results obtained in my empirical work dealing with discretionary accruals and audit fees. I begin my analysis in this chapter with summary descriptive statistics of the variables employed in my empirical work. The empirical results indicate that the majority of the firm-years comprising my sample involve an auditor from one of the Big 4 audit firms, or an audit firm whose principal offices are located in either Auckland or Wellington. Moreover, a large number of the New Zealand listed firms comprising my sample have a fiscal year end which falls into the period from 31 March to 30 June (the busy audit season) and a relatively low number of client firms which receive a qualified or modified audit opinion involving a change in auditor.

Section 6.2 then went on to summarise the empirical results obtained for the Frankel et al. (2002), Antle et al. (2006) and Cahan et al. (2008) model which deals with the impact that the BIG4, AOFFICE, AO, FISCAL, RNAF and C_AUDITOR audit factors have on the level of DACCs. This section also summarises the empirical results obtained for the Simunic (1980) audit fee model which tests for the impact that the level of DACCs in the current year have on the level of the audit fee in next ensuring year. Consistent with the hypotheses developed in chapter 4, the empirical results summarised in this section show that the level of DACCs is significantly and negatively associated with the BIG4 and AOFFICE variables. Moreover, the level of DACCs is also significantly and positively associated with the FISCAL and $\mathrm{AO}$ variables. In contrast, my empirical results report an insignificant relationship between the level of DACCs and the C_AUDITOR and RNAF variables. As expected, the empirical results relating to the Simunic (1980) audit fee model show a positive and statistically significant relationship between the level of DACCs in the current year and the level of the audit fee in the next ensuing year. 


\section{CHAPTER 7}

\section{SUMMARY AND CONCLUDING DISCUSSION}

In chapter seven, I provide an overall summary of the conclusions obtained from the empirical work contained in the thesis and discuss their implications for researchers, regulators, users of published financial statements and client firm managers. Moreover, this chapter also outlines the major limitations associated with the empirical work summarised in the thesis. Finally, the chapter provides some suggestions for future research.

\subsection{Summary and Main Findings}

Recent financial crises along with numerous audit failures have raised the question of auditor competence and independence in the advanced industrialised world. This has prompted a plethora of research that deals with the nature of auditor quality, auditor independence and its relationship to the quality of the audit reports appearing in published financial statements. The research summarised in this thesis contributes to this debate by focusing on two research issues of particular importance to the New Zealand economy. First, the thesis examines the impact of audit factors (such as auditor quality and auditor independence) on the level of earnings management. Second, the thesis empirically assesses the relationship between the level of earnings management and the audit fees charged by audit firms. Here I use discretionary accruals (DACCs) as a proxy for earnings management. The prior literature reports that both negative and positive DACCs can reflect a high level of earnings manipulation. In particular, large negative accruals (for example, prepaid telephone expense) can be used to conceal poor performance by inflating current earnings whilst large positive accruals (for example, accrued telephone expense) can be used to conceal poor future 
performance by reducing current earnings in order to artificially inflate future earnings. Thus, in the empirical work summarised in this thesis I use the absolute value of the DACCs as a proxy for earnings management.

I estimate DACCs for each sample firm by using the Modified Jones (1991) model as developed by Dechow et al. (1995). Moreover, several auditor characteristics have been employed in the thesis as proxies for auditor quality and independence. I use a BIG4 dummy variable (that equals 1 if the auditor is a Big 4 audit firm and 0 otherwise), an AOFFICE dummy variable (that equals 1 if the audit firm's office is located in Wellington or Auckland and 0 otherwise) and an AO dummy variable (that equals 1 if the client firm receives a qualified or conditional audit opinion and 0 otherwise) as proxies for audit quality. I also use a FISCAL dummy variable (that equals 1 if the client firm's fiscal year-end falls in the period from 31 March to 30 June and 0 otherwise) to examine the impact of the busy audit season on the level of DACCs. The busy audit season is normally associated with problems of auditor stress and burnout that in turn can reduce the level of auditor efficiency. I employ a RNAF variable (as measured by the ratio of non-audit fees to total fees paid) and a C_AUDITOR dummy variable (that equals 1 if a client firm changes its audit firm and 0 otherwise) as proxies for auditor independence in relation to the level of DACCs.

In order to examine the impact of the aforementioned audit factors (BIG4, AOFFICE, AO, FISCAL, RNAF and C_AUDITOR) on the level of DACCs, I employ the regression procedures previously invoked by Frankel et al. (2002), Antle et al. (2006) and Cahan et al. (2008) for my sample of 567 firm-years listed on the New Zealand Stock Exchange and covering the period from 2006 until 2010. The empirical results summarised in the thesis show that the level of DACCs is significantly and negatively associated with the BIG4 and AOFFICE variables. This result is consistent with the common perception that the engagement of higher quality audit 
firms will lead to higher quality and more rigorous audit procedures and that these in turn will lead to a reduced level of DACCs. I also find a positive and statistically significant relationship between the FISCAL variable and the level of DACCs. This result indicates that DACCs are likely to be higher if the audit is conducted in the busy audit season. The empirical results summarised in the thesis also show a positive and significant relationship between the audit opinion (AO) variable and the level of DACCs. This means that a qualified or conditional audit opinion is more likely to occur if the financial statements involve a relatively high level of DACCs. However, the empirical results summarised in the thesis report an insignificant relationship between the level of DACCs and the C_AUDITOR and RNAF variables. These results mean that auditor independence does not appear to have any impact on the level of DACCs.

The second part of this thesis examines whether the level of DACCs in the current year are associated with the level of the audit fee in the next ensuing year. Here it is well known that each year the auditor will review both the general and specific factors affecting their audit responsibilities in relation to a particular audit client. They will then determine what they consider to be an appropriate level of audit fee for the next ensuing year. Likewise, the senior management in conjunction the audit committee of the particular audit client will determine what they consider to be an appropriate audit fee for the next ensuing year. Then by a process of bargaining and gaming the audit client and audit firm will come to an agreement about the level of the audit fee to be paid in the next ensuing year. The gaming aspect of the negotiations will be based on the way the auditor has resolved the accounting and auditing issues that have arisen during prior year audits as well as the expressed intentions of the audit firm and desires of the audit client about the way the audit ought to be conducted and the audit and accounting issues resolved in the next ensuing year. Hence, the agreed audit fee for the next ensuing year is likely to reflect 
information about the level of earnings management in prior years and of how the issues arising out of these earnings management procedures have been resolved between the client firm and the audit firm. In order to test this hypotheses, I employ the audit fee model of Simunic (1980) as refined by Choi et al. (2009), Francis and Simon (1987), Hay et al. (2006b) and Menon and Williams (2001). As expected, the second set of empirical results summarised in the thesis show a positive and statistically significant relationship between the level of DACCs in the current year and the level of the audit fee in the next ensuing year. This means that a high level of DACCs in the current year will impact positively on the level of the audit fee in the next ensuing year.

My empirical results are robust with respect to a number of sensitivity tests. First, the White (1980) adjustment procedure has been applied to all regressions summarised in the thesis in order to mitigate econometric issues associated with heteroscedastic error terms. Second, the variance inflation factor (VIF) and the Condition Number Test have been used to check for issues of multicolinearity that might arise with the regression procedures summarised in the thesis. Third, I use the cluster option in all regressions summarised in the thesis in order to check for the undue influence of any given year and/or firm on the main results. Fourth, I use the "eivreg regression" option in the STATA software package to make allowances for potential measurement errors when estimating regression coefficients. Finally, I use several alternative procedures for estimating DACCs in order to assess the robustness of my empirical results with respect to the modified Jones (1991) model. In all instances I find that the regression procedures summarised in the thesis are robust with respect to the particular test applied. 


\subsection{Discussion and Contributions}

\subsubsection{Auditor Quality and Discretionary Accruals}

This thesis contributes to the auditing literature in several significant aspects. First, as noted in the previous section, the empirical results summarised in the thesis show that auditor quality is significantly associated with earnings management amongst New Zealand firms. In particular, my empirical results show that Big 4 auditors are more likely to provide a higher level of audit quality than non-Big 4 auditors in terms of the level of DACCs. These results provide confirmation in a New Zealand context of the theory developed by DeAngelo (1981b) (as in section 4.1) which says that larger audit firms have a bigger reputational capital to protect and therefore, will have a greater incentive to guard against potential litigation risks. This in turn will mean that they will take a more conservative approach to financial reporting issues than will be the case with smaller audit firms. My results are also consistent with recent empirical evidence that deals with the relationship between Big 4 auditors and the level of discretionary accruals using either US data (DeFond and Subramanyam 1998; Krishnan 2003), Singaporean data (Rusmin 2010) or worldwide data (Francis and Wang 2008). However, it should also be emphasised that my empirical results stand in contrast to those of Cahan et al. (2008) and Sharma et al. (2011), both of whom employ a Big 4 control variable in their empirical analysis based on a sample of New Zealand listed firms covering the period from 1995 until 2001 and from 2004 until 2005, respectively. Both these studies fail to report a significant relationship between the Big 4 auditor variable and the level of DACCs. Therefore, as far as I know, my empirical results are the first confirmation of a significant relationship between a Big 4 auditor variable and the level of DACCs in a New Zealand context.

Moreover, Choi et al. (2010) and Francis and Yu (2009) suggest that audit quality may differ significantly at a regional office level. My empirical results confirm the 
Choi et al. (2010) and Francis and Yu (2009) hypothesis in that I find a negative relationship between the level of DAACs for audit offices located in either Auckland or Wellington when compared to audit offices located in a regional town or city. While Choi et al. (2010) and Francis and Yu (2009) among others examine the impact of audit office size (in terms of number audit clients or total fees received by an audit office), I test the influence of audit office location on the level of DACCs. I propose that in a concentrated audit market like New Zealand (for which around $80 \%$ of the audit offices included in my sample are located in either Auckland or Wellington), the audit office location variable employed in my empirical analysis will not only capture the impact of audit office size but also, the improvements in audit quality that inevitably flow from access to the more sophisticated audit technologies that are available in major cities or the national capital. As far as I know, my empirical results are the first to find a negative relationship between audit office location and the level of DACCs for audit firms in New Zealand. This and the Big 4 audit quality phenomenon previously referred to have particularly important implications for client firms that are about to make a decision about either appointing a new auditor or changing their incumbent auditor.

\subsubsection{Audit Busy Season and Discretionary Accruals}

The second important implication of the empirical results summarised in chapter 6 is that audits conducted in the busy audit season (that is, 31 March to 30 June) tend to have relatively large and statistically significant DACCs compared with audits conducted outside the busy audit season. This result is consistent with empirical evidence reported by López and Peters (2012) and Jones III et al. (2010) which examines the same hypothesis using U.S. Compustat, Audit Analytics and U.S. survey data, respectively. However, as far as I know, there is no study which directly investigates the relationship between the audit busy season and the level of DACCs in a New Zealand context. Whilst in a New Zealand context, Walker and 
Hay (2013) and Knechel et al. (2012) control for audits conducted in the busy audit season in their investigation of the audit reporting lag, neither study addresses the issue of whether there is any relationship between audits conducted in the busy audit season and the level of DACCs. However, both studies do find that audits conducted in the busy audit season do not have a significantly different audit reporting lag when compared to audits conducted outside of the busy audit season. This in turn may indicate that auditors conducting audit assignments during the busy audit season are prepared to accept a higher level of DACCs in order to insure that the audit is completed to a pre-specified audit reporting deadline.

The empirical results summarised in the thesis have important implications for client firms, audit firms and regulators in New Zealand. First, firms listed on the New Zealand Stock Exchange should exercise considerable caution when choosing their reporting (that is, fiscal) year end. In particular, they would be well advised to avoid the busy audit season (that is, the period from 31 March to 30 June) which, based on my empirical results, will lead to significant reductions in audit quality. On the other hand, audit firms themselves will need to augment the resources they employ during the busy audit season if they are to guarantee a consistent level of audit quality throughout the calendar year. Finally, New Zealand policy makers and regulators should give serious consideration to changing incentive structures so that there is a more even spread of reporting dates for publicly listed firms in New Zealand. For example, currently the New Zealand Inland Revenue Department (IRD) website, $\quad$ http://www.ird.govt.nz/business-income-tax/filingreturns/payingtax-duedates.html, provides the following advice on the choice of accounting year-end:

"The balance date is the end of the accounting year. When you [firms] apply for an IRD number, your [firm's] balance date is 31 March. You [firms] need to apply to us in writing if you [firms] want to request a different balance date. You [firms] 
cannot use a different balance date until you [firms] have received written approval from us [IRD]."

This regulation provides a heavy incentive for firms to choose an accounting yearend date of 31 March and this in turn will inevitably lead to the audit quality issues which arise in the audit busy season as documented in this thesis. My empirical results suggest that these audit quality issues can be easily addressed if the IRD would adopt a more flexible approach to the reporting dates it allows for firms listed on the New Zealand Stock Exchange. This simple policy initiative will reduce the pressure on audit firms during the busy audit season and thereby help to improve audit quality.

\subsubsection{Audit Opinion and Discretionary Accruals}

The third important implication of the empirical results summarised in chapter 6 is that client firms which receive a qualified or conditional audit opinion tend to have relatively large and statistically significant DACCs when compared with firms which receive an unqualified audit opinion. This result provides confirmatory empirical evidence in a New Zealand context for the hypothesis of Francis and Krishnan (1999) and Bradshaw et al. (2002) that auditors will protect themselves against the risk exposure arising from excessive DACCs by lowering the threshold they apply for the issuance of a qualified (or conditional) audit opinion. This is a particularly important implication of my empirical work since I have previously noted (as in section 3.2) that there has been a general consensus in New Zealand that auditing standards are less rigorous than in other advanced industrialised countries. However, my empirical results show that auditors in New Zealand have no less a tendency to issue qualified (or conditional) audit opinions than in any other advanced industrialised country when confronted with the litigation risks associated with excessive levels of earnings management. 


\subsubsection{Auditor Independence and Discretionary Accruals}

The fourth important implication of the empirical results summarised in chapter 6 is that there is no statistically significant relationship between auditor independence and the level of DACCs. Here, I have used two variables as proxies for auditor independence; namely, auditor change (C_AUDITOR) and the non-audit fee ratio (RNAF). My empirical results show that when client firms change their auditor it appears to have no impact on the level of their subsequent DACCs. This, in turn, means that in New Zealand, client firms cannot expect less rigorous audit procedures to be applied by switching their incumbent auditor. This result contrasts with the popular perception that auditor changes are motivated by opportunistic behaviour arising out of a client firm's desire to achieve outcomes more consistent with the reporting objectives the client firm has for its published financial statements (Francis and Wilson, 1988; DeFond, 1992). However, as previously noted (as in section 3.1) this empirical result might be explained by the fact that the audit market in New Zealand is relatively small and so, when auditor changes do occur they typically attract considerable attention from shareholders, investors and the general public. This, in turn, creates significant pressure on incoming auditors to maintain and indeed, enhance the rigor of the audit procedures practised by the outgoing audit firm.

The empirical results summarised in chapter 6 also show that there is an insignificant relationship between the non-audit fee ratio (RNAF) and the level of DACCs. This result means that auditor independence does not appear to be impaired when audit firms provide relatively large levels of non-audit services. My empirical results are also consistent with recent studies that examine this or similar issues in a New Zealand context. For example, Zhang and Emanuel (2008) use a sample of 528 New Zealand firm-year observations covering the period from 1995 until 2001 and find no evidence of a negative association between the level of non- 
audit services and earnings conservatism. Cahan et al. (2008) use a sample of 237 firm-year observations for New Zealand firms listed on the New Zealand Stock Exchange over the period from 1995 until 2001 and find an insignificant relationship between non-audit fee growth and the level of DACCs. Knechel et al. (2012) use a sample of 230 firm-year observations of New Zealand listed firms covering the period from 2004 until 2005 and again report an insignificant relationship between the level of non-audit services and the level of DACCs (which in their study proxies for the level of audit quality). Here, Zhang and Emanuel (2008) note that because of the relatively small size of the audit market in New Zealand, reputation effects and litigation risks will carry considerably more weight with audit firms than the purely economic incentives that arise from the provision of a higher level of non-audit services. Audit firms in New Zealand will, therefore, be more likely to maintain the appearance of audit independence rather than benefit from the additional profits that arise from the provision of relatively high levels of non-audit services.

\subsubsection{Response of Audit fee to Discretionary Accruals}

Finally, consistent with the regulations covering audit fee negotiation and auditor appointments in New Zealand (as in section 3.3), my empirical results show a positive and significant relationship between the level of DACCs in the current year and the level of the audit fee in the next ensuring year. As far as I am aware, my results provide the first empirical evidence dealing with the impact of DACCs in the current year on the level of audit fees in next ensuring year. The empirical results I report relating to this matter have several important implications. First, it strongly suggests that audit fees, when taken in conjunction with other contextual factors, can provide important information for policy makers, regulators, investors and other interested parties about the quality of the audit procedures employed 
and/or the level of auditor independence. Second, this result also provides important empirical evidence in support of the argument suggested by Behn et al. (1999) that client firm satisfaction is positively associated with the level of audit fees paid in the next ensuing year. Third, this result also confirms two crucial characteristics of the audit fee negotiation process that need to be considered by empirical researchers when formulating audit fee models: (1) audit fees are normally negotiated prior to the commencement of an audit assignment (Karen et al. 2011; Hackenbrack et al. 2011) and (2) audit fee negotiation is not a "one shot" negotiation procedure but is repeated each and every year. This in turn raises the possibility that relatively high DACCs in any given year may continue to have an impact on the audit fee paid by a client firm for several years into the future and not just in the current year as assumed by the large majority of audit fee models appearing in the literature. My modelling procedures acknowledge this possibility by allowing the current audit fee to hinge on DACCs lagged by one period.

\subsection{Limitation and Suggestion for Future Research}

Probably the most significant potential limitation associated with my empirical analysis stems from the assumption that the modified Jones (1991) model (as developed by Dechow et al. (1995)) provides an accurate estimate of a firm's DACCs and hence, of the extent to which it has manipulated its reported earnings. Here, several authors have questioned the power of the modified Jones (1991) model to correctly isolate the "discretionary" portion of the accruals comprising a firm's reported earnings (Dechow et al. 2012). Given this, a number of amendments have been proposed to the modified Jones (1991) model, each designed to address one or more of its perceived weaknesses. In particular, Kothari et al. (2005) note that the modified Jones (1991) model does not fully address issues of heteroskedasticity in its parameter estimation procedures and so Kothari 
et al. (2005) use a matched pairs sampling procedure and include an intercept term in an amended version of the modified Jones (1991) model in order to address this issue. Stubben (2010) uses a much more limited set of accruals (e.g. discretionary revenues) instead of total accruals in order to get what he considers to be a less biased, better specified and more powerful measure of earnings management. Here I would note however, that without access to much more detailed information than is available from a firm's published financial statements it is all but impossible to assess the effectiveness of the alternative techniques for isolating discretionary accruals that have been suggested in the literature (Dechow et al. 2012). Insofar as prior empirical research shows that the different models which have been suggested in the literature can lead to radically different estimates of DACCs (Dechow et al. 2012), there is obviously a need to address the issue of the sensitivity of the results reported in this thesis to alternative methods for estimating the DACCs. I do in fact address this issue by estimating the DACCs for my sample of New Zealand firms using the Kothari et al. (2005) model. Suffice it to say that in this unreported analysis there are no significant differences between the empirical results reported in this thesis based on the the modified Jones (1991) estimate of DACCs and those based on the Kothari et al. (2005) model. However, this is obviously an area to which future research could be usefully devoted.

The empirical procedures employed in this thesis are based on a single panel that pools all 576 firm-years comprising my sample. Although all regression procedures employed in this thesis use the White (1980) adjustment procedure to mitigate econometric issues associated with heteroscedastic error terms and I also use the cluster option by year and by firm, it is still the case that the pooled cross section empirical analysis employed in my empirical procedures is less powerful than employing a panel regression model based on industry and year (Dechow et al. 2012). Unfortunately, my sample of listed New Zealand firms did not provide 
sufficient degrees of freedom to employ this latter technique. Future research could expand my current sample by using both listed and unlisted firms in New Zealand. Alternatively, one could use a database from a bigger market like the U.S., Australia or some of the European countries - such as, the U.K. However, I have previously noted (as in Chapter 3) that the New Zealand audit market is relatively small and highly concentrated when compared to other advanced industrialised countries. Given this care would need to be taken in generalising the results obtained from other countries to those which might apply in New Zealand.

The empirical results summarised in this thesis are based on a sample of listed New Zealand firms covering the period from 2006 until 2010. This period precedes May, 2011 when the New Zealand Parliament passed two important acts; namely, the Auditor Regulation Act and the Financial Reporting Amendment Act. The Auditor Regulation Act establishes a new licensing regime for the auditing profession in New Zealand. In particular it gives the Financial Markets Authority (FMA) responsibility for establishing and maintaining an independent audit oversight system which promotes the quality and integrity of auditing practices in New Zealand. Moreover, the Financial Reporting Amendment Act initiates a significant change in audit standard-setting procedures in New Zealand. Responsibility for issuing auditing standards has now been transferred from the New Zealand Institute of Chartered Accountants (NZICA) to the External Reporting Board (XRB) which is an independent government body established by the New Zealand Ministry of Business, Innovation and Employment. These changes will more than likely have a significant impact on auditor independence and audit quality in New Zealand and will open up new research opportunities dealing with the relationship between audit factors and earnings management. For example, future research could investigate the impact of the new licensing regime under the Auditor Regulation Act on the 
relationship between the level of DACCs and the level of audit fees in New Zealand. Future research could also examine the relationship between audit factors (e.g. audit busy season, auditor independence, Big 4 audit firms, etc.) and the level of DACCs under the new audit quality oversight regime of the FMA and/or the new audit standards issued by the XRB.

Last but not least, I agree with Ball (2013, p. 850) when he states that earnings management is "a powerful cocktail of authors' strong priors, strong ethical and moral views, limited knowledge of the determinants of accruals in the absence of manipulation, and willingness to ignore correlated omitted variables in order to report a result." This in turn means that there are potential control variables which impact on the level of DACCs that may have been omitted from my regression models. Larcker and Richardson (2004), for example, argue that good corporate governance helps to mitigate the inherent agency problems that arise in publicly traded firms and thereby improves financial information quality. Therefore, future research might consider whether it is advisable to incorporate corporate governance characteristics such as outside ownership and board independence as control variables in the earnings management models developed in this thesis. Moreover, whilst the earnings management models developed in this thesis include a dummy variable, EMI, that controls for earnings management that might arise when a firm either buys back or offers new shares to the stock market, there are still a plethora of other different incentives for firms to manipulate their earnings figure for which I have not controlled (Dechow et al. 1996). Future research, therefore, could also control for these factors, such as the incentives that firms have to maintain an upwardly trending earnings per share figure or the incentives that arise to manipulate earnings because of earnings-based bonus schemes. 


\subsection{Conclusion}

Chapter seven provides an overall summary of the conclusions obtained from the empirical work contained in this thesis and discusses their implications for researchers, regulators, users of published financial statements and client firm managers. First, as far as I am aware, my empirical results provide the first confirmation of a significant association between the Big 4 auditor (BIG4), audit office location (AOFFICE), audit opinion (AO) and audit busy season (FISCAL) audit factors and the level of DACCs in a New Zealand context. Moreover, my results also provide the first empirical evidence dealing with the impact of DACCs on the level of audit fees in the next ensuring year. Second, my empirical results have particularly important implications for client firms that are about to make decisions relating to: (1) the appointment of a new auditor and/or (2) changing their incumbent auditor and/or (3) choosing the fiscal year end. Third, my empirical results also suggest that New Zealand policy makers and regulators should give serious consideration to changing incentive structures so that there is a more even spread of reporting dates for publicly listed firms in New Zealand. Fourth, my empirical results report no serious issues with the changing of an incumbent auditor or the provision of non-audit services in relation to auditor independence. I also note that auditors in New Zealand have no less a tendency to issue qualified (or conditional) audit opinions than in any other advanced industrialised country when confronted with the litigation risks associated with excessive levels of earnings management. Moreover, my empirical results also strongly suggest that audit fees, when taken in conjunction with other contextual factors, can provide information for policy makers, regulators, investors and other interested parties about the quality of the audit procedures employed and/or the level of auditor independence. 
Chapter seven closes with a summary of the major limitations associated with the empirical work summarised in this thesis and makes several suggestions for future research. My first observation here is that future research could examine the hypotheses advanced in this thesis by using alternative methods for estimating the level of DACCs. Second, future research could increase the sample size employed in empirical work by using both listed and unlisted firms in New Zealand. Alternatively, one could use a database from a bigger market like the U.S., Australia or some of the European countries - such as, the U.K. Future research could also examine the relationship between audit factors (e.g. audit busy season, auditor independence, Big 4 audit firms) and the level of DACCs under the new audit quality oversight regime of the Financial Markets Authority (FMA) and/or the new audit standards issued by the External Reporting Board (XRB) in New Zealand. Finally, future research might consider whether it is advisable to incorporate corporate governance characteristics or earnings management incentives as control variables in the earnings management models developed in this thesis. 
APPENDIX 1: LIST OF 143 FIRMS INCLUDED IN MY SAMPLE

\begin{tabular}{|c|c|c|c|c|c|c|c|c|c|c|}
\hline $\begin{array}{c}\text { Group } \\
\text { No }\end{array}$ & $\begin{array}{c}\text { Total } \\
\text { No } \\
\end{array}$ & $\begin{array}{l}\text { Code } \\
\text { Name } \\
\end{array}$ & FULL NAME & $\begin{array}{l}\text { NZSX } \\
\text { Listed }\end{array}$ & $\begin{array}{c}\text { NZAX } \\
\text { listed }\end{array}$ & $\begin{array}{l}\text { NZDX } \\
\text { Listed }\end{array}$ & $\begin{array}{c}\text { Listing } \\
\text { Year }\end{array}$ & $\begin{array}{c}\text { Delisting } \\
\text { year }\end{array}$ & $\begin{array}{l}\text { Firm- } \\
\text { Years }\end{array}$ & $\begin{array}{c}\text { Included } \\
\text { Years } \\
\end{array}$ \\
\hline 1 & 1 & ABA & Abano Healthcare Group Limited & 1 & 0 & 0 & 1962 & & 7 & 2004-2010 \\
\hline 2 & 2 & AIA & Auckland International Airport Limited & 1 & 0 & 1 & 2004 & & 7 & 2004-2010 \\
\hline 3 & 3 & ALF & Allied Farmers Limited & 1 & 0 & 1 & 2002 & & 7 & 2004-2010 \\
\hline 4 & 4 & ANO & AMP NZ Office Limited & 1 & 0 & 0 & 2010 & & 7 & 2004-2010 \\
\hline 5 & 5 & $\mathrm{ARG}$ & Argosy Property Trust & 1 & 0 & 0 & 2002 & & 7 & 2004-2010 \\
\hline 6 & 6 & ATM & A2 Corporation Limited & 0 & 1 & 0 & 2004 & & 7 & 2004-2010 \\
\hline 7 & 7 & BGR & Briscoe Group Limited & 1 & 0 & 0 & 2001 & & 7 & 2004-2010 \\
\hline 8 & 8 & BLT & BLIS Technologies Limited & 1 & 0 & 0 & 2001 & & 7 & 2004-2010 \\
\hline 9 & 9 & CAV & Cavalier Corporation Limited & 1 & 0 & 0 & 1984 & & 7 & 2004-2010 \\
\hline 10 & 10 & CBS & Canterbury Building Society & 1 & 0 & 0 & 2004 & 2010 & 7 & 2004-2010 \\
\hline 11 & 11 & CDI & CDL Investments New Zealand Limited & 1 & 0 & 0 & 1905 & & 7 & 2004-2010 \\
\hline 12 & 12 & CEN & Contact Energy Limited & 1 & 0 & 1 & 1999 & & 7 & 2004-2010 \\
\hline 13 & 13 & CLA & Claridge Capital Limited & 1 & 0 & 0 & 1986 & & 6 & 2004-2010 \\
\hline 14 & 14 & $\mathrm{CMO}$ & The Colonial Motor Company Limited & 1 & 0 & 0 & 1962 & & 7 & 2004-2010 \\
\hline 15 & 15 & CVT & Comvita Limited & 1 & 0 & 0 & 2006 & & 7 & 2003-2010 \\
\hline 16 & 16 & CYT & Cynotech Holdings Limited & 0 & 1 & 1 & 2010 & & 7 & 2003-2010 \\
\hline 17 & 17 & $\mathrm{DPC}$ & Dorchester Pacific Limited & 1 & 0 & 1 & 1905 & & 7 & 2004-2010 \\
\hline 18 & 18 & EBO & Ebos Group Limited & 1 & 0 & 0 & 1960 & & 7 & 2004-2010 \\
\hline 19 & 19 & FBU & Fletcher Building Limited & 1 & 0 & 0 & 1996 & & 7 & 2004-2010 \\
\hline
\end{tabular}




\begin{tabular}{|c|c|c|c|c|c|c|c|c|c|c|}
\hline $\begin{array}{l}\text { Group } \\
\text { No }\end{array}$ & $\begin{array}{c}\text { Total } \\
\text { No }\end{array}$ & $\begin{array}{c}\text { Code } \\
\text { Name }\end{array}$ & FULL NAME & $\begin{array}{l}\text { NZSX } \\
\text { Listed }\end{array}$ & $\begin{array}{c}\text { NZAX } \\
\text { listed }\end{array}$ & $\begin{array}{l}\text { NZDX } \\
\text { Listed }\end{array}$ & $\begin{array}{c}\text { Listing } \\
\text { Year }\end{array}$ & $\begin{array}{c}\text { Delisting } \\
\text { year }\end{array}$ & $\begin{array}{l}\text { Firm- } \\
\text { Years }\end{array}$ & $\begin{array}{c}\text { Included } \\
\text { Years }\end{array}$ \\
\hline 20 & 20 & FIN & Finzsoft Solutions Limited & 1 & 0 & 0 & 2000 & & 7 & $2004-2010$ \\
\hline 21 & 21 & FMG & Forge Media Group Limited & 0 & 1 & 0 & 2005 & & 7 & 2004-2010 \\
\hline 22 & 22 & FPA & Fisher\&Paykel Appliances Holdings Limited & 1 & 0 & 0 & 2001 & & 7 & 2004-2010 \\
\hline 23 & 23 & FPH & Fisher \& Paykel Industries Limited & 1 & 0 & 0 & 1979 & & 7 & 2004-2010 \\
\hline 24 & 24 & FRE & Freightways Limited & 1 & 0 & 0 & 2003 & & 7 & 2004-2010 \\
\hline 25 & 25 & GEN & Genesis Research\&Development Limited & 1 & 0 & 0 & 2000 & & 7 & 2004-2010 \\
\hline 26 & 26 & GMT & Goodman Property Trust & 1 & 0 & 0 & 1999 & & 7 & 2004-2010 \\
\hline 27 & 27 & HBY & Hellaby Holdings Limited & 1 & 0 & 0 & 1994 & & 7 & 2004-2010 \\
\hline 28 & 28 & HED & Horizon Energy Distribution Limited & 1 & 0 & 0 & 1995 & & 7 & 2004-2010 \\
\hline 29 & 29 & HGD & Heritage Gold NZ Limited & 1 & 0 & 0 & 1986 & & 7 & 2004-2010 \\
\hline 30 & 30 & HLG & Hallenstein Glasson Holdings Limited & 1 & 0 & 0 & 1947 & & 7 & 2004-2010 \\
\hline 31 & 31 & IFT & Infrastructure \& Utilities NZ Limited & 1 & 0 & 1 & 1994 & & 7 & 2004-2010 \\
\hline 32 & 32 & INS & Insured Group Limited & 1 & 0 & 0 & 1987 & & 7 & 2004-2010 \\
\hline 33 & 33 & JWI & Just Water International Limited & 0 & 1 & 0 & 2004 & & 7 & 2004-2010 \\
\hline 34 & 34 & KIP & Kiwi Income Property Trust & 1 & 0 & 0 & 1993 & & 7 & 2004-2010 \\
\hline 35 & 35 & KRK & Kirkcaldie \& Stains Limited & 1 & 0 & 0 & 2001 & & 7 & 2004-2010 \\
\hline 36 & 36 & LIC & Livestock Improvement Corporation Limited & 0 & 1 & 0 & 2004 & & 7 & 2004-2010 \\
\hline 37 & 37 & MCK & Millennium\&Copthorne Hotels New Zealand & 1 & 0 & 0 & 1985 & 1989 & 7 & 2004-2010 \\
\hline 38 & 38 & MET & Metropolitan Lifecare Group Limited & 1 & 0 & 0 & 1994 & & 7 & 2004-2010 \\
\hline 39 & 39 & MFT & Mainfreight Limited & 1 & 0 & 0 & 1996 & & 7 & 2004-2010 \\
\hline 40 & 40 & MGL & Mercer Group Limited & 1 & 0 & 0 & 1959 & & 7 & 2004-2010 \\
\hline
\end{tabular}




\begin{tabular}{|c|c|c|c|c|c|c|c|c|c|c|}
\hline $\begin{array}{l}\text { Group } \\
\text { No }\end{array}$ & $\begin{array}{c}\text { Total } \\
\text { No }\end{array}$ & $\begin{array}{c}\text { Code } \\
\text { Name }\end{array}$ & FULL NAME & $\begin{array}{l}\text { NZSX } \\
\text { Listed }\end{array}$ & $\begin{array}{c}\text { NZAX } \\
\text { listed }\end{array}$ & $\begin{array}{l}\text { NZDX } \\
\text { Listed }\end{array}$ & $\begin{array}{c}\text { Listing } \\
\text { Year }\end{array}$ & $\begin{array}{c}\text { Delisting } \\
\text { year }\end{array}$ & $\begin{array}{l}\text { Firm- } \\
\text { Years }\end{array}$ & $\begin{array}{c}\text { Included } \\
\text { Years }\end{array}$ \\
\hline 41 & 41 & MHI & Michael Hill International Limited & 1 & 0 & 0 & 1987 & & 7 & $2004-2010$ \\
\hline 42 & 42 & MOW & Mowbray Collectables Limited & 1 & 0 & 0 & 2000 & & 7 & 2004-2010 \\
\hline 43 & 43 & MVN & Methven Limited & 1 & 0 & 0 & 2004 & & 7 & 2004-2010 \\
\hline 44 & 44 & & New Image Group Limited & 1 & 0 & 0 & 2000 & 1989 & 7 & 2004-2010 \\
\hline 45 & 45 & NAP & National Property Trust & 1 & 0 & 0 & 1900 & 2011 & 7 & 2004-2010 \\
\hline 46 & 46 & NPX & Nuplex Industries Limited & 1 & 0 & 1 & 2002 & & 7 & 2004-2010 \\
\hline 47 & 47 & NWC & The New Zealand Wine Company Limited & 0 & 1 & 0 & 2003 & & 7 & 2004-2010 \\
\hline 48 & 48 & NZE & New Zealand Experience Limited & 1 & 0 & 0 & 1991 & & 7 & 2004-2010 \\
\hline 49 & 49 & $\mathrm{NZF}$ & NZF Group Limited & 1 & 0 & 1 & 2004 & & 7 & 2004-2010 \\
\hline 50 & 50 & $\mathrm{NZO}$ & New Zealand Oil \& Gas Limited & 1 & 0 & 0 & 1981 & & 7 & 2004-2010 \\
\hline 51 & 51 & NZR & The New Zealand Refining Company & 1 & 0 & 0 & 1962 & & 7 & 2004-2010 \\
\hline 52 & 52 & NZX & New Zealand Exchange Limited & 1 & 0 & 0 & 2003 & & 7 & 2004-2010 \\
\hline 53 & 53 & OBV & Oyster Bay Marlborough Vineyards Limited & 1 & 0 & 0 & 2003 & 2011 & 7 & 2004-2010 \\
\hline 54 & 54 & PEB & Pacific Edge Biotechnology Limited & 1 & 0 & 0 & 2003 & & 7 & 2004-2010 \\
\hline 55 & 55 & PFI & Property for Industry Limited & 1 & 0 & 0 & 1994 & & 7 & 2004-2010 \\
\hline 56 & 56 & PGC & Pyne Gould Corporation Limited & 1 & 0 & 0 & 2004 & & 7 & 2004-2010 \\
\hline 57 & 57 & PGW & PGG Wrightson Limited & 1 & 0 & 0 & 1905 & & 7 & 2004-2010 \\
\hline 58 & 58 & PHB & Pharmacybrands Limited & 1 & 0 & 0 & 2000 & & 7 & 2004-2010 \\
\hline 59 & 59 & PPG & Postie Plus Group Limited & 1 & 0 & 0 & 2003 & & 7 & 2004-2010 \\
\hline 60 & 60 & PPL & Pumpkin Patch Limited & 1 & 0 & 0 & 2004 & & 7 & 2004-2010 \\
\hline 61 & 61 & PWC & Powerco Limited & 0 & 0 & 1 & 2000 & 2004 & 7 & 2004-2010 \\
\hline
\end{tabular}




\begin{tabular}{|c|c|c|c|c|c|c|c|c|c|c|}
\hline $\begin{array}{c}\text { Group } \\
\text { No }\end{array}$ & $\begin{array}{c}\text { Total } \\
\text { No }\end{array}$ & $\begin{array}{c}\text { Code } \\
\text { Name }\end{array}$ & FULL NAME & $\begin{array}{l}\text { NZSX } \\
\text { Listed }\end{array}$ & $\begin{array}{c}\text { NZAX } \\
\text { listed }\end{array}$ & $\begin{array}{l}\text { NZDX } \\
\text { Listed }\end{array}$ & $\begin{array}{c}\text { Listing } \\
\text { Year }\end{array}$ & $\begin{array}{c}\text { Delisting } \\
\text { year }\end{array}$ & $\begin{array}{l}\text { Firm- } \\
\text { Years }\end{array}$ & $\begin{array}{c}\text { Included } \\
\text { Years } \\
\end{array}$ \\
\hline 62 & 62 & RBD & Restaurant Brands New Zealand Limited & 1 & 0 & 0 & 1997 & & 7 & $2004-2010$ \\
\hline 63 & 63 & RNS & Renaissance Corporation Limited & 1 & 0 & 0 & 1905 & & 7 & 2004-2010 \\
\hline 64 & 64 & RYM & Ryman Healthcare Limited & 1 & 0 & 0 & 1999 & & 7 & 2004-2010 \\
\hline 65 & 65 & SAN & Sanford Limited & 1 & 0 & 0 & 1904 & & 7 & 2004-2010 \\
\hline 66 & 66 & SAT & Satara Co-operative Group & 0 & 1 & 0 & 2004 & & 7 & $2004-2010$ \\
\hline 67 & 67 & SCT & Scott Technology Limited & 1 & 0 & 0 & 1997 & & 7 & $2004-2010$ \\
\hline 68 & 68 & SCY & Smiths City Group Limited & 1 & 0 & 0 & 2004 & & 7 & $2004-2010$ \\
\hline 69 & 69 & SDL & Solution Dynamics Limited & 0 & 1 & 0 & 2004 & & 7 & 2004-2010 \\
\hline 70 & 70 & SGL & Speirs Group Limited & 0 & 1 & 0 & 2004 & & 7 & 2004-2010 \\
\hline 71 & 71 & SKC & Sky City Limited & 1 & 0 & 1 & 2000 & & 7 & 2004-2010 \\
\hline 72 & 72 & SKL & Skellmax Industries Limited & 1 & 0 & 0 & 2002 & 1996 & 7 & 2004-2010 \\
\hline 73 & 73 & SLG & Sealegs Corporation Limited & 1 & 0 & 0 & 1994 & & 7 & 2004-2010 \\
\hline 74 & 74 & SPN & South Port New Zealand Limited & 1 & 0 & 0 & 1994 & & 7 & 2004-2010 \\
\hline 75 & 75 & SPY & Smartpay Limited & 1 & 0 & 0 & 1987 & & 7 & 2004-2010 \\
\hline 76 & 76 & STH & Southern Travel Holdings Limited & 0 & 1 & 0 & 2004 & & 6 & 2005-2010 \\
\hline 77 & 77 & STU & Steel \& Tube Holdings Limited & 1 & 0 & 0 & 1967 & & 7 & $2004-2010$ \\
\hline 78 & 78 & SVY & Savoy Equities Limited & 1 & 0 & 0 & 1983 & & 7 & $2004-2010$ \\
\hline 79 & 79 & TEL & Telecom Corporation of NZ Limited & 1 & 0 & 0 & 1991 & & 7 & $2004-2010$ \\
\hline 80 & 80 & THL & Tmyism Holdings Limited & 1 & 0 & 0 & 1986 & & 7 & 2004-2010 \\
\hline 81 & 81 & TPW & TrustPower Limited & 1 & 0 & 1 & 2002 & & 7 & 2004-2010 \\
\hline 82 & 82 & TRS & TRS Investments Limited & 1 & 0 & 0 & 2000 & & 7 & 2004-2010 \\
\hline
\end{tabular}




\begin{tabular}{|c|c|c|c|c|c|c|c|c|c|c|}
\hline $\begin{array}{l}\text { Group } \\
\text { No }\end{array}$ & $\begin{array}{c}\text { Total } \\
\text { No }\end{array}$ & $\begin{array}{c}\text { Code } \\
\text { Name }\end{array}$ & FULL NAME & $\begin{array}{l}\text { NZSX } \\
\text { Listed }\end{array}$ & $\begin{array}{c}\text { NZAX } \\
\text { listed }\end{array}$ & $\begin{array}{l}\text { NZDX } \\
\text { Listed }\end{array}$ & $\begin{array}{c}\text { Listing } \\
\text { Year }\end{array}$ & $\begin{array}{c}\text { Delisting } \\
\text { year }\end{array}$ & $\begin{array}{l}\text { Firm- } \\
\text { Years }\end{array}$ & $\begin{array}{c}\text { Included } \\
\text { Years }\end{array}$ \\
\hline 83 & 83 & TTK & TeamTalk Limited & 1 & 0 & 0 & 2004 & & 7 & $2004-2010$ \\
\hline 84 & 84 & TUA & Turners Auctions Limited & 1 & 0 & 0 & 2002 & & 7 & 2004-2010 \\
\hline 85 & 85 & TUR & Turners \& Growers Limited & 1 & 0 & 0 & 2004 & & 7 & 2004-2010 \\
\hline 86 & 86 & TWR & Tower Limited & 1 & 0 & 0 & 1999 & & 7 & 2004-2010 \\
\hline 87 & 87 & VCT & Vector Limited & 1 & 0 & 1 & 2005 & & 6 & 2005-2010 \\
\hline 88 & 88 & VHP & Vital Healthcare Property Trust & 1 & 0 & 0 & 1999 & & 7 & 2004-2010 \\
\hline 89 & 89 & IL & Wool Equities Limited & 0 & 1 & 0 & 2003 & 1996 & 7 & 2004-2010 \\
\hline 90 & 90 & WFD & Wakefield Hospital Limited & 1 & 0 & 0 & 2001 & & 7 & 2004-2010 \\
\hline 91 & 91 & WHS & The Warehouse Group Limited & 1 & 0 & 1 & 1994 & & 7 & 2004-2010 \\
\hline 92 & 92 & WID & Widespread Portfolios Limited & 1 & 0 & 0 & 2000 & & 7 & 2004-2010 \\
\hline 93 & 93 & WSI & NZ Wool Services International Limited & 0 & 1 & 0 & 2004 & & 7 & 2004-2010 \\
\hline 94 & 94 & WTL & Windflow Technology Limited & 0 & 1 & 0 & 2003 & & 7 & 2004-2010 \\
\hline 95 & 95 & $\mathrm{ZIN}$ & Zintel Communications Limited & 0 & 1 & 0 & 2003 & & 7 & 2004-2010 \\
\hline 96 & 96 & AWF & Allied Work Force Group Limited & 1 & 0 & 0 & 2005 & & 5 & 2006-2010 \\
\hline 97 & 97 & CNX & Connexionz Limited & 1 & 0 & 0 & 2004 & 2009 & 6 & 2004-2009 \\
\hline 98 & 98 & JTM & Jasons Travel Media Limited & 0 & 1 & 0 & 2005 & & 5 & 2006-2010 \\
\hline 99 & 99 & PFG & Propertyfinance Group Limited & 1 & 0 & 0 & 2005 & 2010 & 6 & 2004-2009 \\
\hline 100 & 100 & RPL & Richina Pacific Limited & 0 & 0 & 1 & 1905 & 2009 & 4 & 2004-2007 \\
\hline 101 & 101 & SKT & Sky Network Television Limited & 1 & 0 & 0 & 2005 & & 5 & 2006-2010 \\
\hline 102 & 102 & TAY & Taylors Group Limited & 1 & 0 & 0 & 1905 & 2009 & 6 & 2004-2009 \\
\hline 103 & 103 & $\mathrm{BRM}$ & Barramundi Limited & 1 & 0 & 0 & 2006 & & 4 & $2007-2010$ \\
\hline
\end{tabular}




\begin{tabular}{|c|c|c|c|c|c|c|c|c|c|c|}
\hline $\begin{array}{l}\text { Group } \\
\text { No }\end{array}$ & $\begin{array}{c}\text { Total } \\
\text { No }\end{array}$ & $\begin{array}{c}\text { Code } \\
\text { Name }\end{array}$ & FULL NAME & $\begin{array}{l}\text { NZSX } \\
\text { Listed }\end{array}$ & $\begin{array}{c}\text { NZAX } \\
\text { listed }\end{array}$ & $\begin{array}{l}\text { NZDX } \\
\text { Listed }\end{array}$ & $\begin{array}{c}\text { Listing } \\
\text { Year }\end{array}$ & $\begin{array}{c}\text { Delisting } \\
\text { year }\end{array}$ & $\begin{array}{l}\text { Firm- } \\
\text { Years }\end{array}$ & $\begin{array}{c}\text { Included } \\
\text { Years }\end{array}$ \\
\hline 104 & 104 & CRP & Chatham Rock Phosphate Limited & 0 & 0 & 1 & 2006 & & 4 & $2007-2010$ \\
\hline 105 & 105 & CTG & Cabletalk Group Limited & 0 & 0 & 1 & 2000 & 2008 & 4 & 2004-2007 \\
\hline 106 & 106 & CTL & Cadmus Technology Limited & 0 & 0 & 1 & 2000 & 2008 & 4 & 2004-2007 \\
\hline 107 & 107 & DEL & Dairy Equity Limited & 0 & 1 & 1 & 2006 & 2010 & 3 & 2007-2009 \\
\hline 108 & 108 & DFH & Dominion Finance Holdings Limited & 1 & 0 & 0 & 2006 & 2010 & 4 & $2005-2008$ \\
\hline 109 & 109 & DGL & Delegat's Group Limited & 1 & 0 & 0 & 2006 & & 6 & $2005-2010$ \\
\hline 110 & 110 & GEM & Global Market Equity Securities Limited & 1 & 0 & 0 & 2002 & 2008 & 4 & 2004-2007 \\
\hline 111 & 111 & IRG & Investment Research Group Limited & 0 & 1 & 0 & 2006 & & 4 & $2007-2010$ \\
\hline 112 & 112 & KPF & Kermadec Property Fund Limited & 1 & 0 & 0 & 2006 & & 4 & $2007-2010$ \\
\hline 113 & 113 & LBS & Loan \& Building Society & 1 & 0 & 0 & 2003 & 2008 & 4 & 2004-2007 \\
\hline 114 & 114 & $\mathrm{MCH}$ & Mr Chips Holdings Limited & 1 & 0 & 0 & 1993 & 2008 & 5 & 2004-2008 \\
\hline 115 & 115 & RAK & Rakon Limited & 0 & 0 & 1 & 2006 & & 5 & 2006-2010 \\
\hline 116 & 116 & VIX & VIX International Limited & 1 & 0 & 0 & 1997 & 2008 & 4 & 2004-2007 \\
\hline 117 & 117 & BFW & Burger Fuel Worldwide Limited & 1 & 0 & 0 & 2007 & & 3 & $2008-2010$ \\
\hline 118 & 118 & CGL & The CACI Group Limited & 1 & 0 & 0 & 2003 & 2007 & 3 & 2004-2006 \\
\hline 119 & 119 & KID & Kidicorp Group Limited & 1 & 0 & 0 & 2001 & 2007 & 4 & 2004-2007 \\
\hline 120 & 120 & MLN & Marlin Global Limited & 1 & 0 & 0 & 2007 & & 3 & $2008-2010$ \\
\hline 121 & 121 & MWL & Mediaworks NZ Limited & 1 & 0 & 0 & 2004 & 2007 & 3 & 2004-2006 \\
\hline 122 & 122 & NMN & News \& Media NZ Limited & 0 & 1 & 0 & 1996 & 2007 & 3 & 2004-2006 \\
\hline 123 & 123 & NWF & NZ Windfarms Limited & 1 & 0 & 1 & 2007 & & 5 & 2006-2010 \\
\hline 124 & 124 & OIC & Opus International Consultants Limited & 1 & 0 & 0 & 2007 & & 4 & $2007-2010$ \\
\hline
\end{tabular}




\begin{tabular}{|c|c|c|c|c|c|c|c|c|c|c|}
\hline $\begin{array}{c}\text { Group } \\
\text { No }\end{array}$ & $\begin{array}{c}\text { Total } \\
\text { No }\end{array}$ & $\begin{array}{c}\text { Code } \\
\text { Name }\end{array}$ & FULL NAME & $\begin{array}{l}\text { NZSX } \\
\text { Listed }\end{array}$ & $\begin{array}{l}\text { NZAX } \\
\text { listed }\end{array}$ & $\begin{array}{l}\text { NZDX } \\
\text { Listed }\end{array}$ & $\begin{array}{c}\text { Listing } \\
\text { Year }\end{array}$ & $\begin{array}{c}\text { Delisting } \\
\text { year }\end{array}$ & $\begin{array}{l}\text { Firm- } \\
\text { Years }\end{array}$ & $\begin{array}{c}\text { Included } \\
\text { Years } \\
\end{array}$ \\
\hline 125 & 125 & PLU & Pulse Utilities New Zealand Limited & 0 & 0 & 1 & 2007 & & 3 & $2008-2010$ \\
\hline 126 & 126 & POD & POD Limited & 0 & 0 & 1 & 1993 & 2007 & 3 & 2004-2006 \\
\hline 127 & 127 & PRC & Pike River Coal Limited & 0 & 0 & 1 & 2007 & & 4 & $2007-2010$ \\
\hline 128 & 128 & SCL & Southern Capital Limited & 1 & 0 & 0 & 1997 & 2007 & 3 & 2004-2006 \\
\hline 129 & 129 & SOE & Software of Excellence International Limited & 1 & 0 & 0 & 2000 & 2007 & 4 & 2004-2007 \\
\hline 130 & 130 & TRH & Toll NZ Limited & 1 & 0 & 0 & 1996 & 2007 & 4 & 2004-2007 \\
\hline 131 & 131 & TTP & Trans Tasman Properties Limited & 1 & 0 & 1 & 1982 & 2007 & 3 & 2004-2006 \\
\hline 132 & 132 & $\mathrm{XRO}$ & Xero Live Limited & 1 & 0 & 0 & 2007 & & 3 & $2008-2010$ \\
\hline 133 & 133 & AFF & AFFCO Holdings Limited & 1 & 0 & 0 & 1995 & 2010 & 6 & 2004-2009 \\
\hline 134 & 134 & APF & Apple Fields Limited & 0 & 0 & 1 & 1986 & 2010 & 5 & 2004-2008 \\
\hline 135 & 135 & $\mathrm{CHA}$ & Charlie's Group Limited & 1 & 0 & 0 & 1983 & & 5 & 2006-2010 \\
\hline 136 & 136 & EHF & Eastern Hi Fi Group Limited & 1 & 0 & 0 & 2004 & 2010 & 5 & 2004-2008 \\
\hline 137 & 137 & KFL & Kingfish Limited & 1 & 0 & 0 & 2004 & & 6 & 2005-2010 \\
\hline 138 & 138 & PLS & Plus SMS Holdings Limited & 0 & 0 & 1 & 2003 & 2010 & 3 & $2006-2008$ \\
\hline 139 & 139 & $\mathrm{PVO}$ & Provencocadmus Limited & 1 & 0 & 0 & 2002 & & 5 & 2004-2008 \\
\hline 140 & 140 & SAM & Salvus Strategic Investments Limited & 1 & 0 & 0 & 2004 & & 6 & $2005-2010$ \\
\hline 141 & 141 & SEK & Seeka Kiwifruit Industries Limited & 1 & 0 & 0 & 2003 & & 6 & $2005-2010$ \\
\hline 142 & 142 & VTL & VTL Group Limited & 1 & 0 & 0 & 2000 & 2010 & 4 & 2004-2007 \\
\hline 143 & 143 & WDT & Wellington Drive Technologies Limited & 1 & 0 & 0 & 2001 & & 6 & 2005-2010 \\
\hline
\end{tabular}


APPENDIX 2: LIST OF 60 FIRMS LISTED ONLY IN NZDX DURING THE PERIOD FROM 2004-2010

\begin{tabular}{|c|c|c|c|c|c|c|c|c|}
\hline $\begin{array}{c}\text { Group } \\
\text { No }\end{array}$ & $\begin{array}{c}\text { Total } \\
\text { No }\end{array}$ & $\begin{array}{c}\text { Code } \\
\text { Name }\end{array}$ & FULL NAME & $\begin{array}{l}\text { NZSX } \\
\text { Listed }\end{array}$ & $\begin{array}{c}\text { NZAX } \\
\text { listed }\end{array}$ & $\begin{array}{l}\text { NZDX } \\
\text { Listed }\end{array}$ & Listing Year & $\begin{array}{c}\text { Delisting } \\
\text { year }\end{array}$ \\
\hline 1 & 144 & AQN & AMP Group Finance Services Limited & 0 & 0 & 1 & 2009 & \\
\hline 2 & 145 & ANB & ANZ National Bank Limited & 0 & 0 & 1 & 2002 & \\
\hline 3 & 146 & APM & APM Media (NZ) Limited & 0 & 0 & 1 & 2010 & \\
\hline 4 & 147 & $\mathrm{AKC}$ & Auckland Council & 0 & 0 & 1 & 2009 & \\
\hline 5 & 148 & $\mathrm{BNZ}$ & Bank of New Zealand & 0 & 0 & 1 & 2007 & \\
\hline 6 & 149 & BLU & Blue Star Group Limited & 0 & 0 & 1 & 2002 & \\
\hline 7 & 150 & BNS & BNZ Income Securities 2 Limited & 0 & 0 & 1 & 2009 & \\
\hline 8 & 151 & BIS & BNZ Income Securities Limited & 0 & 0 & 1 & 2008 & \\
\hline 9 & 152 & $\mathrm{CBA}$ & CBA Capital Australia Limited & 0 & 0 & 1 & & \\
\hline 10 & 153 & CAS & Credit Agricole S.A. & 0 & 0 & 1 & 2007 & \\
\hline 11 & 154 & $\mathrm{CSA}$ & Credit Sail Limited & 0 & 0 & 1 & 2006 & \\
\hline 12 & 155 & FDY & Fidelity Capital Guaranteed Bond Limited & 0 & 0 & 1 & 2007 & \\
\hline 13 & 156 & FBI & Fletcher Building Industries Limited & 0 & 0 & 1 & 2002 & \\
\hline 14 & 157 & FCG & Fonterra Co-operative Group Limited & 0 & 0 & 1 & 2001 & \\
\hline 15 & 158 & GTR & Generator Bonds Limited & 0 & 0 & 1 & 2003 & \\
\hline 16 & 159 & GPL & Genesis Power Limited & 0 & 0 & 1 & 2011 & \\
\hline 17 & 160 & GMB & GMT Bond Issuer Limited & 0 & 0 & 1 & 2009 & \\
\hline 18 & 161 & GFZ & Goodman Fielder New Zealand Limited & 0 & 0 & 1 & 2010 & \\
\hline
\end{tabular}




\begin{tabular}{|c|c|c|c|c|c|c|c|c|}
\hline $\begin{array}{l}\text { Group } \\
\text { No }\end{array}$ & $\begin{array}{l}\text { Total } \\
\text { No }\end{array}$ & $\begin{array}{l}\text { Code } \\
\text { Name }\end{array}$ & FULL NAME & $\begin{array}{l}\text { NZSX } \\
\text { Listed }\end{array}$ & $\begin{array}{c}\text { NZAX } \\
\text { listed }\end{array}$ & $\begin{array}{l}\text { NZDX } \\
\text { Listed }\end{array}$ & Listing Year & $\begin{array}{l}\text { Delisting } \\
\text { year }\end{array}$ \\
\hline 19 & 162 & GFN & GPG Finance PLC & 0 & 0 & 1 & 2001 & \\
\hline 20 & 163 & MAR & Heartland Building Society & 0 & 0 & 1 & 2011 & 2010 \\
\hline 21 & 164 & $\mathrm{KCS}$ & Kiwi Capital Securities Limited & 0 & 0 & 1 & 2010 & \\
\hline 22 & 165 & FTN & Macquarie Fortress Investments Limited & 0 & 0 & 1 & 2005 & \\
\hline 23 & 166 & MEL & Meridian Energy Limited & 0 & 0 & 1 & 2010 & \\
\hline 24 & 167 & MTF & Motor Trade Finances Limited & 0 & 0 & 1 & 1994 & \\
\hline 25 & 168 & GOV & New Zealand Government Stock & 0 & 0 & 1 & & \\
\hline 26 & 169 & $\mathrm{NZP}$ & New Zealand Post Group Finance Limited & 0 & 0 & 1 & 2009 & \\
\hline 27 & 170 & $\mathrm{NFF}$ & Nufarm Finance (NZ) Limited & 0 & 0 & 1 & & \\
\hline 28 & 171 & $\mathrm{OCF}$ & Origin Energy Contact Finance No.2 Limited & 0 & 0 & 1 & 2007 & \\
\hline 29 & 172 & PWF & PGG Wrightson Finance Limited & 0 & 0 & 1 & 2005 & \\
\hline 30 & 173 & PNZ & PINs Securities NZ Limited & 0 & 0 & 1 & 2005 & \\
\hline 31 & 174 & PIN & $\begin{array}{l}\text { Prime Infrastructure Networks (New } \\
\text { Zealand) Limited }\end{array}$ & 0 & 0 & $\mathbf{1}$ & 2004 & \\
\hline 32 & 175 & QHL & Quayside Holdings Limited & 0 & 0 & 1 & 2008 & \\
\hline 33 & 176 & $\mathrm{RCS}$ & Rabo Capital Securities Limited & 0 & 0 & 1 & 2009 & \\
\hline 34 & 177 & $\mathrm{RBO}$ & Rabobank Nederland & 0 & 0 & $\mathbf{1}$ & 2007 & \\
\hline 35 & 178 & RMT & RMB Trustee Limited & 0 & 0 & $\mathbf{1}$ & 2007 & \\
\hline 36 & 179 & $\mathrm{TCN}$ & TCNZ Finance Limited & 0 & 0 & 1 & & \\
\hline 37 & 180 & TWC & Tower Capital Limited & 0 & 0 & $\mathbf{1}$ & 2009 & \\
\hline
\end{tabular}




\begin{tabular}{|c|c|c|c|c|c|c|c|c|}
\hline $\begin{array}{l}\text { Group } \\
\text { No }\end{array}$ & $\begin{array}{c}\text { Total } \\
\text { No }\end{array}$ & $\begin{array}{l}\text { Code } \\
\text { Name }\end{array}$ & FULL NAME & $\begin{array}{l}\text { NZSX } \\
\text { Listed }\end{array}$ & $\begin{array}{l}\text { NZAX } \\
\text { listed }\end{array}$ & $\begin{array}{l}\text { NZDX } \\
\text { Listed }\end{array}$ & Listing Year & $\begin{array}{c}\text { Delisting } \\
\text { year }\end{array}$ \\
\hline 38 & 181 & $\mathrm{UOC}$ & University of Canterbury & 0 & 0 & 1 & 2009 & \\
\hline 39 & 182 & WIA & Wellington International Airport Limited & 0 & 0 & 1 & 2008 & \\
\hline 40 & 183 & WKS & Works Finance (NZ) Limited & 0 & 0 & 1 & 2007 & 1991 \\
\hline 41 & 184 & ZEL & Z Energy Limited & 0 & 0 & 1 & 2010 & \\
\hline 42 & 185 & & Burns Philp Finance New Zealand Limited & 0 & 0 & 1 & & \\
\hline 43 & 186 & & Irongate Property Limited & 0 & 0 & 1 & & \\
\hline 44 & 187 & $\mathrm{SCF}$ & South Canterbury Finance Limited & 0 & 0 & 1 & 2006 & 2011 \\
\hline 45 & 188 & MAR & MARAC Finance Limited & 0 & 0 & 1 & 2011 & 2010 \\
\hline 46 & 189 & ARW & RED group Retail Pty Limited & 0 & 0 & 1 & 2004 & 2010 \\
\hline 47 & 190 & ANF & Allied Nationwide Finance Limited & 0 & 0 & $\mathbf{1}$ & 2008 & 2010 \\
\hline 48 & 191 & SFF & Silver Fern Farms Limited & 0 & 0 & 1 & 2004 & 2010 \\
\hline 49 & 192 & $\mathrm{RPC}$ & Rural Portfolio Capital Limited & 0 & 0 & 1 & 2007 & 2010 \\
\hline 50 & 193 & $\mathrm{CNZ}$ & Capital Properties New Zealand Limited & 0 & 0 & 1 & 2000 & 2010 \\
\hline 51 & 194 & SFL & Strategic Finance Limited & 0 & 0 & 1 & 2007 & 2010 \\
\hline 52 & 195 & $\mathrm{CDV}$ & Cadmus Developments Limited & 0 & 0 & 1 & 2007 & 2010 \\
\hline 53 & 196 & $\mathrm{BNB}$ & Babcock \& Brown Limited & 0 & 0 & 1 & 2006 & 2009 \\
\hline 54 & 197 & RPI & $\begin{array}{l}\text { Rural Portfolio Investments Securities } \\
\text { Limited }\end{array}$ & 0 & 0 & 1 & 2004 & 2009 \\
\hline 55 & 198 & GCN & Global Corporate Credit Limited & 0 & 0 & 1 & 2003 & 2008 \\
\hline 56 & 199 & HYF & HY-FI Securities Limited & 0 & 0 & 1 & 2003 & 2008 \\
\hline
\end{tabular}




\begin{tabular}{|c|c|c|l|c|c|c|c|c|}
\hline $\begin{array}{c}\text { Group } \\
\text { No }\end{array}$ & $\begin{array}{c}\text { Total } \\
\text { No }\end{array}$ & $\begin{array}{c}\text { Code } \\
\text { Name }\end{array}$ & \multicolumn{1}{|c|}{ FULL NAME } & $\begin{array}{c}\text { NZSX } \\
\text { Listed }\end{array}$ & $\begin{array}{c}\text { NZAX } \\
\text { listed }\end{array}$ & $\begin{array}{c}\text { NZDX } \\
\text { Listed }\end{array}$ & $\begin{array}{c}\text { Listing Year } \\
\text { Delisting } \\
\text { year }\end{array}$ \\
\hline 57 & 200 & AHH & Australasian Hotel Holdings Limited & 0 & 0 & $\mathbf{1}$ & 2003 & 2008 \\
\hline 58 & 201 & NCN & NPT Capital Limited & 0 & 0 & $\mathbf{1}$ & 2001 & 2007 \\
\hline 59 & 202 & BFL & BIL Finance Limited & 0 & 0 & $\mathbf{1}$ & 2007 \\
\hline 60 & 203 & GGR & Pacific Print Group Limited & 0 & 0 & $\mathbf{1}$ & 2004 & 2007 \\
\hline
\end{tabular}


APPENDIX 3: LIST OF 61 FIRMS DELISTED BEFORE 2006

\begin{tabular}{|c|c|c|c|c|c|c|c|c|}
\hline $\begin{array}{l}\text { Group } \\
\text { No }\end{array}$ & $\begin{array}{c}\text { Total } \\
\text { No }\end{array}$ & $\begin{array}{l}\text { Code } \\
\text { Name }\end{array}$ & FULL NAME & $\begin{array}{l}\text { NZSX } \\
\text { Listed }\end{array}$ & $\begin{array}{c}\text { NZAX } \\
\text { listed }\end{array}$ & $\begin{array}{l}\text { NZDX } \\
\text { Listed }\end{array}$ & $\begin{array}{c}\text { Listing } \\
\text { year }\end{array}$ & $\begin{array}{c}\text { Delisting } \\
\text { year }\end{array}$ \\
\hline 1 & 204 & FTB & 42 Below Limited & 0 & 0 & 0 & 2003 & 2006 \\
\hline 2 & 205 & MPM & Mike Pero Mortgages Limited & 0 & 0 & 0 & 2004 & 2006 \\
\hline 3 & 206 & $\mathrm{BCF}$ & Blue Chip Financial Solutions Limited & 0 & 0 & 0 & 1983 & 2006 \\
\hline 4 & 207 & GLS & Gullivers Travel Group Limited & 0 & 0 & 0 & 2004 & 2006 \\
\hline 5 & 208 & PRG & PRG Group Limited & 0 & 0 & 0 & 2002 & 2006 \\
\hline 6 & 209 & OPI & Opio Forestry Fund & 0 & 0 & 0 & 1905 & 2006 \\
\hline 7 & 210 & GDC & GDC Communications Limited & 0 & 0 & 0 & 2000 & 2006 \\
\hline 8 & 211 & EVF & Evergreen Forests Limited & 0 & 0 & 0 & 1993 & 2006 \\
\hline 9 & 212 & MPS & Origin Energy Contact Finance Limited & 0 & 0 & 0 & & 2006 \\
\hline 10 & 213 & WAM & Waste Management NZ Limited & 0 & 0 & 0 & 1970 & 2006 \\
\hline 11 & 214 & $\mathrm{CNZ}$ & Capital Properties New Zealand Limited & 0 & 0 & 0 & 2000 & 2010 \\
\hline 12 & 215 & $\mathrm{CAH}$ & Carter Holt Harvey Limited & 0 & 0 & 0 & 1971 & 2006 \\
\hline 13 & 216 & AXA & $\begin{array}{l}\text { AXA Asia Pacific Holdings Limited (Overseas } \\
\text { Issuer) }\end{array}$ & 0 & 0 & 0 & 1996 & 2006 \\
\hline 14 & 217 & MON & Montana Group (NZ) Limited & 0 & 0 & 0 & 1985 & 2006 \\
\hline 15 & 218 & $\mathrm{RCL}$ & Repco Corporation Limited (Dual-listed Issuer) & 0 & 0 & 0 & 2003 & 2006 \\
\hline 16 & 219 & UTC & Utilico Investment Trust plc (Overseas Issuer) & 0 & 0 & 0 & 2003 & 2005 \\
\hline 17 & 220 & $\mathrm{AMC}$ & Amcor Limited (Overseas Issuer) & 0 & 0 & 0 & & 2005 \\
\hline
\end{tabular}




\begin{tabular}{|c|c|c|c|c|c|c|c|c|}
\hline $\begin{array}{l}\text { Group } \\
\text { No }\end{array}$ & $\begin{array}{c}\text { Total } \\
\text { No }\end{array}$ & $\begin{array}{l}\text { Code } \\
\text { Name }\end{array}$ & FULL NAME & $\begin{array}{l}\text { NZSX } \\
\text { Listed }\end{array}$ & $\begin{array}{l}\text { NZAX } \\
\text { listed }\end{array}$ & $\begin{array}{l}\text { NZDX } \\
\text { Listed }\end{array}$ & $\begin{array}{l}\text { Listing } \\
\text { year }\end{array}$ & $\begin{array}{c}\text { Delisting } \\
\text { year }\end{array}$ \\
\hline 18 & 221 & CML & Coles Myer Limited (Overseas Issuer) & 0 & 0 & 0 & 1992 & 2005 \\
\hline 19 & 222 & ELC & Electricity Corporation of NZ Limited & 0 & 0 & 0 & 1993 & 2005 \\
\hline 20 & 223 & FML & FinMedia Limited & 0 & 0 & 0 & 1995 & 2005 \\
\hline 21 & 224 & WRI & Wrightson Limited & 0 & 0 & 0 & 1993 & 2005 \\
\hline 22 & 225 & NGC & $\begin{array}{l}\text { Natural Gas Corporation Holdings Limited (still } \\
\text { NZDX Issuer) }\end{array}$ & 0 & 0 & 0 & & 2005 \\
\hline 23 & 226 & MTM & M2M Corporation Limited (Overseas issuer) & 0 & 0 & 0 & & 2005 \\
\hline 24 & 227 & POA & Ports of Auckland Limited & 0 & 0 & 0 & 1993 & 2005 \\
\hline 25 & 228 & URB & Urbus Properties Limited & 0 & 0 & 0 & 2003 & 2005 \\
\hline 26 & 229 & GNS & GPG (UK) Holdings Plc (Overseas Issuer) & 0 & 0 & 0 & & 2005 \\
\hline 27 & 230 & ANG & Anglo \& Overseas Trust PLC (Overseas Issuer) & 0 & 0 & 0 & & 2005 \\
\hline 28 & 231 & OWN & Owens Group Limited & 0 & 0 & 0 & 1985 & 2005 \\
\hline 29 & 232 & WPT & Westpac (NZ) Investments Limited & 0 & 0 & 0 & 1999 & 2005 \\
\hline 30 & 233 & INL & Independent Newspapers Limited & 0 & 0 & 0 & 1905 & 2005 \\
\hline 31 & 234 & SKY & Sky Network Television Limited & 0 & 0 & 0 & 2001 & 2005 \\
\hline 32 & 235 & $\mathrm{FCE}$ & $\begin{array}{l}\text { F\&C Emerging Markets Investment Trust PLC } \\
\text { (Overseas issuer) }\end{array}$ & 0 & 0 & 0 & & 2005 \\
\hline 33 & 236 & IIN & IINet Limited (Overseas issuer) & 0 & 0 & 0 & 2004 & 2005 \\
\hline 34 & 237 & LKO & Lakes Oil NL (Overseas issuer) & 0 & 0 & 0 & & 2005 \\
\hline 35 & 238 & NUH & Nuhaka Farm Forestry Fund & 0 & 0 & 0 & 1905 & 2005 \\
\hline 36 & 239 & STO & Santos Limited (Overseas issuer) & 0 & 0 & 0 & & 2005 \\
\hline
\end{tabular}




\begin{tabular}{|c|c|c|c|c|c|c|c|c|}
\hline $\begin{array}{l}\text { Group } \\
\text { No }\end{array}$ & $\begin{array}{c}\text { Total } \\
\text { No }\end{array}$ & $\begin{array}{l}\text { Code } \\
\text { Name }\end{array}$ & FULL NAME & $\begin{array}{l}\text { NZSX } \\
\text { Listed }\end{array}$ & $\begin{array}{c}\text { NZAX } \\
\text { listed }\end{array}$ & $\begin{array}{l}\text { NZDX } \\
\text { Listed }\end{array}$ & $\begin{array}{c}\text { Listing } \\
\text { year }\end{array}$ & $\begin{array}{l}\text { Delisting } \\
\text { year }\end{array}$ \\
\hline 37 & 240 & $\mathrm{CPU}$ & Computershare Limited (Overseas Issuer) & 0 & 0 & 0 & 1994 & 2005 \\
\hline 38 & 241 & CUE & Cue Energy Resmyces Limited (Overseas Issuer) & 0 & 0 & 0 & 2009 & 2005 \\
\hline 39 & 242 & VTX & Vertex Group Holdings Limited & 0 & 0 & 0 & 2002 & 2005 \\
\hline 40 & 243 & PMP & PMP Communications Limited (Overseas issuer) & 0 & 0 & 0 & & 2005 \\
\hline 41 & 244 & WKL & Williams \& Kettle Limited & 0 & 0 & 0 & 1993 & 2005 \\
\hline 42 & 245 & PWC & Powerco Limited (still NZDX Issuer) & 0 & 0 & 0 & 2000 & 2004 \\
\hline 43 & 246 & $\mathrm{NCP}$ & The News Corporation Limited (Overseas Issuer) & 0 & 0 & 0 & & 2004 \\
\hline 44 & 247 & MRP & $\begin{array}{l}\text { Merrill Lynch European Investment Trust PLC } \\
\text { (Overseas Issuer) }\end{array}$ & 0 & 0 & 0 & & 2004 \\
\hline 45 & 248 & DBB & DB Breweries Limited & 0 & 0 & 0 & 1964 & 2004 \\
\hline 46 & 249 & TGG & $\begin{array}{l}\text { Templeton Global Growth Fund Limited (Overseas } \\
\text { Issuer) }\end{array}$ & 0 & 0 & 0 & & 2004 \\
\hline 47 & 250 & RHD & Richmond Limited & 0 & 0 & 0 & 2001 & 2004 \\
\hline 48 & 251 & KIN & Kingsgate International Corporation Limited & 0 & 0 & 0 & 1905 & 2004 \\
\hline 49 & 252 & SUB & Submarines Australasia Limited & 0 & 0 & 0 & 2000 & 2004 \\
\hline 50 & 253 & $\mathrm{ABN}$ & $\begin{array}{l}\text { Aberdeen New Dawn Investment Trust PLC } \\
\text { (Overseas Issuer) }\end{array}$ & 0 & 0 & 0 & & 2004 \\
\hline 51 & 254 & MRP & $\begin{array}{l}\text { Merrill Lynch European Investments Trust PLC } \\
\text { (Overseas Issuer) }\end{array}$ & 0 & 0 & 0 & & 2004 \\
\hline 52 & 255 & SLL & Sky City Leisure Limited & 0 & 0 & 0 & 1987 & 2004 \\
\hline 53 & 256 & WFT & Westfield Trust (Overseas Issuer) & 0 & 0 & 0 & & 2004 \\
\hline 54 & 257 & EBT & eBet Limited (Overseas Issuer) & 0 & 0 & 0 & & 2004 \\
\hline
\end{tabular}




\begin{tabular}{|c|c|c|l|c|c|c|c|c|}
\hline $\begin{array}{c}\text { Group } \\
\text { No }\end{array}$ & $\begin{array}{c}\text { Total } \\
\text { No }\end{array}$ & $\begin{array}{c}\text { Code } \\
\text { Name }\end{array}$ & \multicolumn{1}{|c|}{ FULL NAME } & $\begin{array}{c}\text { NZSX } \\
\text { Listed }\end{array}$ & $\begin{array}{c}\text { NZAX } \\
\text { listed }\end{array}$ & $\begin{array}{c}\text { NZDX } \\
\text { Listed }\end{array}$ & $\begin{array}{c}\text { Listing } \\
\text { year }\end{array}$ & $\begin{array}{c}\text { Delisting } \\
\text { year }\end{array}$ \\
\hline 55 & 258 & PMM & Portman Limited (Overseas Issuer) & 0 & 0 & 0 & $\mathbf{2 0 0 4}$ \\
\hline 56 & 259 & MOS & Mosaic Oil NL (Overseas Issuer) & 0 & 0 & 0 & \\
\hline 57 & 260 & ANN & Ansell Limited (Overseas Issuer) & 0 & 0 & 0 & $\mathbf{2 0 0 4}$ \\
\hline 58 & 261 & SJL & Shotover Jet Limited & 0 & 0 & 0 & 1993 & $\mathbf{2 0 0 4}$ \\
\hline 59 & 262 & BHP & BHP Billiton Limited (Overseas Issuer) & 0 & 0 & 0 & \\
\hline 60 & 263 & AMK & $\begin{array}{l}\text { AMP Reset Preferred Securities (Non-standard } \\
\text { Issuer) }\end{array}$ & 0 & 0 & 0 & 2002 & $\mathbf{2 0 0 4}$ \\
\hline 61 & 264 & CVN & Carnarvon Petroleum NL (Overseas Issuer) & 0 & 0 & 0 & & $\mathbf{2 0 0 4}$ \\
\hline
\end{tabular}


APPENDIX 4: LIST OF 12 FIRMS LISTED AFTER 2008

\begin{tabular}{|c|c|c|l|c|c|c|c|c|}
\hline $\begin{array}{c}\text { Group } \\
\text { No }\end{array}$ & $\begin{array}{c}\text { Total } \\
\text { No }\end{array}$ & $\begin{array}{c}\text { Code } \\
\text { Name }\end{array}$ & \multicolumn{1}{|c|}{ FULL NAME } & $\begin{array}{c}\text { NZSX } \\
\text { Listed }\end{array}$ & $\begin{array}{c}\text { NZAX } \\
\text { listed }\end{array}$ & $\begin{array}{c}\text { NZDX } \\
\text { Listed }\end{array}$ & Listing Year & Delisting year \\
\hline 1 & 204 & BTU & Bathurst Resmyces Limited & 0 & 1 & 0 & $\mathbf{2 0 1 0}$ & \\
\hline 2 & 205 & ANO & AMP NZ Office Limited & 0 & 1 & 0 & $\mathbf{2 0 1 0}$ & \\
\hline 3 & 206 & DNZ & DNZ Property Fund Limited & 0 & 1 & 0 & $\mathbf{2 0 1 0}$ & \\
\hline 4 & 207 & ECO & Ecoya Limited & 0 & 1 & 0 & $\mathbf{2 0 1 0}$ & \\
\hline 5 & 208 & CYT & Cynotech Holdings Limited & 1 & 0 & 1 & $\mathbf{2 0 1 0}$ & \\
\hline 6 & 209 & SPT & Spotless Group Limited & 0 & 1 & 0 & $\mathbf{2 0 0 9}$ & \\
\hline 7 & 210 & KMD & Kathmandu Holdings Limited & 0 & 1 & 0 & $\mathbf{2 0 0 9}$ & \\
\hline 8 & 211 & CUE & Cue Energy Resmyces Limited & 1 & 0 & 0 & $\mathbf{2 0 0 9}$ & 2010 \\
\hline 9 & 212 & BOZ & Botry-Zen Limited & 1 & 0 & 0 & $\mathbf{2 0 0 8}$ & \\
\hline 10 & 213 & CFG & Cooks Food Group Limited & 1 & 0 & 0 & $\mathbf{2 0 0 8}$ & \\
\hline 11 & 214 & GFL & GFNZ Group Limited & 0 & 1 & 0 & $\mathbf{2 0 0 8}$ & 2010 \\
\hline 12 & 215 & CEI & Celsius New Zealand Income Fund Series 1 & 0 & \\
\hline
\end{tabular}


APPENDIX 5: LIST OF 2 FIRMS WHOSE LISTING TIME IS LESS THAN 3 YEARS

\begin{tabular}{|c|c|c|l|c|c|c|c|c|}
\hline $\begin{array}{c}\text { Group } \\
\text { No }\end{array}$ & $\begin{array}{c}\text { Total } \\
\text { No }\end{array}$ & $\begin{array}{c}\text { Code } \\
\text { Name }\end{array}$ & \multicolumn{1}{|c|}{ FULL NAME } & $\begin{array}{c}\text { NZSX } \\
\text { Listed }\end{array}$ & $\begin{array}{c}\text { NZAX } \\
\text { listed }\end{array}$ & $\begin{array}{c}\text { NZDX } \\
\text { Listed }\end{array}$ & Listing Year & Delisting year \\
\hline 1 & 277 & $\underline{\text { MFN }}$ & OPI New Zealand Limited & 0 & 1 & 0 & $\mathbf{2 0 0 7}$ & $\mathbf{2 0 0 9}$ \\
\hline 2 & 278 & $\underline{\text { LLA }}$ & Living and Leisure Australia Limited & 0 & 1 & 0 & $\mathbf{2 0 0 7}$ & $\mathbf{2 0 0 8}$ \\
\hline
\end{tabular}


APPENDIX 6: LIST OF 26 FIRMS WHOSE DATA IS MISSING FROM MY DATABASE

\begin{tabular}{|c|c|c|c|c|c|c|c|c|}
\hline $\begin{array}{c}\text { Group } \\
\text { No } \\
\end{array}$ & $\begin{array}{c}\text { Total } \\
\text { No } \\
\end{array}$ & $\begin{array}{c}\text { Code } \\
\text { Name } \\
\end{array}$ & FULL NAME & $\begin{array}{l}\text { NZSX } \\
\text { Listed } \\
\end{array}$ & $\begin{array}{c}\text { NZAX } \\
\text { listed }\end{array}$ & $\begin{array}{l}\text { NZDX } \\
\text { Listed } \\
\end{array}$ & $\begin{array}{c}\text { Listing } \\
\text { Year }\end{array}$ & $\begin{array}{c}\text { Delisting } \\
\text { year }\end{array}$ \\
\hline 1 & 279 & CUE & Cue Energy Resmyces Limited & 0 & 1 & 0 & 2009 & \\
\hline 2 & 280 & FNZ & SmartFONZ & 0 & 1 & 0 & 2004 & \\
\hline 3 & 281 & ARG & Argosy Property Trust & 0 & 1 & 0 & 2002 & \\
\hline 4 & 282 & MDZ & SmartMIDZ & 0 & 1 & 0 & 1997 & \\
\hline 5 & 283 & FMG & Forge Media Group Limited & 1 & 0 & 0 & 2005 & \\
\hline 6 & 284 & MZY & SmartMOZY & 0 & 1 & 0 & 2004 & \\
\hline 7 & 285 & NTH & Northland Port Corporation (NZ) Limited & 0 & 1 & 0 & 1992 & \\
\hline 8 & 286 & $\mathrm{OZY}$ & SmartOZZY & 0 & 1 & 0 & 1997 & \\
\hline 9 & 287 & POT & Port of Tauranga Limited & 0 & 1 & 0 & 1992 & \\
\hline 10 & 288 & TNZ & SmartTENZ & 0 & 1 & 0 & 1996 & \\
\hline 11 & 289 & GFF & Goodman Fielder Limited & 0 & 1 & 0 & 2005 & \\
\hline 12 & 290 & LNN & Lion Nathan Limited & & & & 1958 & \\
\hline 13 & 291 & $\mathrm{BIO}$ & ICP Biotechnology Limited & & & & 2000 & \\
\hline 14 & 292 & GEL & Glass Earth Gold Limited & 1 & 0 & 0 & 2006 & \\
\hline 15 & 293 & RIS & RIS Group Limited & 1 & 0 & 0 & 2006 & \\
\hline 16 & 294 & DIL & Diligent Board Member Services INC & 0 & 1 & 0 & 2007 & \\
\hline 17 & 295 & SSE & Sunseeker Energy (Austaliasia) Limited & & & & 2007 & \\
\hline 18 & 296 & AMP & AMP Limited & 0 & 1 & 0 & 1998 & \\
\hline
\end{tabular}




\begin{tabular}{|c|c|c|c|c|c|c|c|c|}
\hline $\begin{array}{c}\text { Group } \\
\text { No }\end{array}$ & $\begin{array}{c}\text { Total } \\
\text { No }\end{array}$ & $\begin{array}{l}\text { Code } \\
\text { Name }\end{array}$ & FULL NAME & $\begin{array}{l}\text { NZSX } \\
\text { Listed }\end{array}$ & $\begin{array}{c}\text { NZAX } \\
\text { listed }\end{array}$ & $\begin{array}{l}\text { NZDX } \\
\text { Listed }\end{array}$ & $\begin{array}{c}\text { Listing } \\
\text { Year }\end{array}$ & $\begin{array}{c}\text { Delisting } \\
\text { year }\end{array}$ \\
\hline 19 & 297 & ANZ & Australia and New Zealand Banking Group Limited & 0 & 1 & 0 & 1988 & \\
\hline 20 & 298 & APN & APN News \& Media Limited & 0 & 1 & 0 & 2004 & \\
\hline 21 & 299 & APX & Austral Pacific Energy Limited & & & & 2004 & \\
\hline 22 & 300 & FTX & Feltex Carpets Limited & & & & 2004 & \\
\hline 23 & 301 & LPC & Lyttelton Port Company Limited & 0 & 1 & 0 & 1996 & \\
\hline 24 & 302 & WIN & AMP Investments' World Index Fund & 0 & 1 & 0 & 1997 & \\
\hline 25 & 303 & AIR & Air New Zealand Limited & 0 & 1 & 0 & 1989 & \\
\hline 26 & 304 & ASB & ASB Capital Limited & 0 & 1 & 0 & 2002 & \\
\hline
\end{tabular}


APPENDIX 7: LIST OF 9 FIRMS WHOSE DATA IS MISSING FROM MY DATABASE

\begin{tabular}{|c|c|c|l|c|c|c|c|c|}
\hline $\begin{array}{c}\text { Group } \\
\text { No }\end{array}$ & $\begin{array}{c}\text { Total } \\
\text { No }\end{array}$ & $\begin{array}{c}\text { Code } \\
\text { Name }\end{array}$ & \multicolumn{1}{|c|}{ FULL NAME } & $\begin{array}{c}\text { NZSX } \\
\text { Listed }\end{array}$ & $\begin{array}{c}\text { NZAX } \\
\text { listed }\end{array}$ & $\begin{array}{c}\text { NZDX } \\
\text { Listed }\end{array}$ & Listing Year & Currency \\
\hline 1 & 305 & GLL & Guocoleisure Limited & 0 & 1 & 0 & 1970 & USD \\
\hline 2 & 306 & RBC & Rubicon Limited & 0 & 1 & 0 & 2001 & USD \\
\hline 3 & 307 & TEN & Tenon Limited & 0 & 1 & 0 & 1996 & USD \\
\hline 4 & 308 & NZS & NZ Farming Systems Uruguay Limited & 0 & 1 & 0 & 2007 & USD \\
\hline 5 & 309 & OMG & Orion Minerals Group Limited & 1 & 0 & 0 & 2007 & USD \\
\hline 6 & 310 & GPG & Guinness Peat Group & 0 & 1 & 0 & 1991 & GBP \\
\hline 7 & 311 & CCC & Cavotec MSL Holdings Limited & 0 & 1 & 0 & 2000 & EUR \\
\hline 8 & 312 & TLS & Telstra Corporation Limited & 0 & 1 & 0 & 1999 & AUD \\
\hline 9 & 313 & WBC & Wespac Banking Corporation Limited & 0 & 1 & 0 & 1999 & AUD \\
\hline
\end{tabular}




\section{REFERENCES}

Abbott, L. J., S. Parker, and G. F. Peters. 2006. Earnings management, litigation risk, and asymmetric audit fee responses. Auditing: A Journal of Practice \& Theory 25 (1):85-98.

Agoglia, C. P., J. F. Brazel, R. C. Hatfield, and S. B. Jackson. 2010. How do audit workpaper reviewers cope with the conflicting pressures of detecting misstatements and balancing client workloads? Auditing: A Journal of Practice \& Theory 29 (2):27-43.

Aharony, J., C. J. LIN, and M. P. Loeb. 1993. Initial Public Offerings, Accounting Choices, and Earnings Management. Contemporary Accounting Research 10 (1):61-81.

Ahmad-Zaluki, N. A., K. Campbell, and A. Goodacre. 2011. Earnings management in Malaysian IPOs: The East Asian crisis, ownership control, and post-IPO performance. The International Journal of Accounting 46 (2):111-137.

Antle, R., E. Gordon, G. Narayanamoorthy, and L. Zhou. 2006. The joint determination of audit fees, non-audit fees, and abnormal accruals. Review of Quantitative Finance and Accounting 27 (3):235-266.

Ashbaugh, H., R. LaFond, and B. W. Mayhew. 2003. Do Nonaudit Services Compromise Auditor Independence? Further Evidence. The Accounting Review 78 (3):611-639.

Ashton, D., Dunmore, P., \& Tippett, M. 2004. Double entry bookkeeping and the distributional properties of a firm's financial ratios. Journal of Business Finance \& Accounting, 31(5 - 6), 583-606.

Baber, W. R., P. M. Fairfield, and J. A. Haggard. 1991. The effect of concern about reported income on discretionary spending decisions: The case of research and development. Accounting Review 66 (4):818-829.

Ball, R. 2013. Accounting informs investors and earnings management is rife: Two questionable beliefs. Accounting Horizons 27 (4): 847 - 853

Bartov, E. 1993. The timing of asset sales and earnings manipulation. Accounting Review 68 (4):840-855.

Bartov, E., D. Givoly, and C. Hayn. 2002. The rewards to meeting or beating earnings expectations. Journal of Accounting and Economics 33 (2):173204. 
Bartov, E., F. A. Gul, and J. S. Tsui. 2000. Discretionary-accruals models and audit qualifications. Journal of Accounting and Economics 30 (3):421-452.

Beaver, W. H., M. F. McNichols, and K. K. Nelson. 2003. Management of the loss reserve accrual and the distribution of earnings in the property-casualty insurance industry. Journal of Accounting and Economics 35 (3):347-376.

Becker, C. L., M. L. DeFond, J. Jiambalvo, and K. R. Subramanyam. 1998. The Effect of Audit Quality on Earnings Management. Contemporary Accounting Research 15 (1):1-24.

Bedard, J. C., and K. M. Johnstone. 2004. Earnings manipulation risk, corporate governance risk, and auditors' planning and pricing decisions. The Accounting Review 79 (2):277-304.

Behn, B. K., J. V. Carcello, D. R. Hermanson, and R. H. Hermanson. 1999. Client Satisfaction and Big 6 Audit Fees. Contemporary Accounting Research 16 (4):587-608.

Beneish, M. D. 1997. Detecting GAAP violation: implications for assessing earnings management among firms with extreme financial performance. Journal of Accounting and Public Policy 16 (3):271-309.

Beneish, M. D., E. Press, and M. E. Vargus. 2012. Insider Trading and Earnings Management in Distressed Firms. Contemporary Accounting Research 29 (1):191-220.

Bens, D. A., V. Nagar, and M. Wong. 2002. Real investment implications of employee stock option exercises. Journal of Accounting Research 40 (2):359-393.

Bishop, M., and E. Eccher. 2000. Do markets remember accounting changes? An examination of subsequent years. An Examination of Subsequent Years (March 17, 2000).

Bradshaw, M. T., S. A. Richardson, and R. G. Sloan. 2002. Do analysts and auditors use information in accruals? Journal of Accounting Research 39 (1):45-74.

Burgstahler, D., and I. Dichev. 1997. Earnings management to avoid earnings decreases and losses. Journal of Accounting and Economics 24 (1):99-126.

Burgstahler, D., and M. Eames. 2006. Management of earnings and analysts' forecasts to achieve zero and small positive earnings surprises. Journal of Business Finance \& Accounting 33 (5 - 6):633-652.

Bushee, B. J. 1998. The Influence of Institutional Investors on Myopic R\&D Investment Behavior. The Accounting Review 73 (3):305-333. 
Cahan, S., D. Emanuel, D. Hay, and N. Wong. 2008. Non-audit fees, long-term auditor-client relationships and earnings management. Accounting \& Finance 48 (2):181-207.

Chambers, D. 1999. Earnings management and capital market misallocation. Available at SSRN 198790.

Charoenwong, C., and P. Jiraporn. 2009. Earnings management to exceed thresholds: Evidence from Singapore and Thailand. Journal of Multinational Financial Management 19 (3):221-236.

Chen, K. Y., K. L. Lin, and J. Zhou. 2005. Audit quality and earnings management for Taiwan IPO firms. Managerial Auditing Journal 20 (1):86-104.

Choi, J.-H., C. F. Kim, J.-B. Kim, and Y. Zang. 2010. Audit Office Size,Audit Quality, and Audit Pricing. Auditing: A Journal of Practice \& Theory 29 (1):73-97.

Choi, J. H., J. B. Kim, X. H. Liu, and D. A. Simunic. 2009. Cross-Listing Audit Fee Premiums: Theory and Evidence. The Accounting Review 84 (5):14291463.

Chung, H., and S. Kallapur. 2003. Client Importance, Nonaudit Services, and Abnormal Accruals. The Accounting Review 78 (4):931-955.

Cohen, D. A., and P. Zarowin. 2010. Accrual-based and real earnings management activities around seasoned equity offerings. Journal of Accounting and Economics 50 (1):2-19.

Cook, K., G. Huston, and M. Kinney. 2011. Managing earnings by manipulating production: The effects of cost structure and inventory valuation method. Available at SSRN 997437.

Coram, P., J. Ng, and D. R. Woodliff. 2004. The Effect of Risk of Misstatement on the Propensity to Commit Reduced Audit Quality Acts under Time Budget Pressure. Auditing: A Journal of Practice \& Theory 23 (2):159-167.

Coulton, J., S. Taylor, and S. Taylor. 2005. Is 'benchmark beating' by Australian firms evidence of earnings management? Accounting \& Finance 45 (4):553-576.

Davidson III, W. N., P. Jiraporn, and P. DaDalt. 2006. Causes and consequences of audit shopping: an analysis of auditor opinions, earnings management, and auditor changes. Quarterly Journal of Business and Economics 45 (1 and 2):69-87. 
Davis, L. R., D. N. Ricchiute, and G. Trompeter. 1993. Audit Effort, Audit Fees, and the Provision of Nonaudit Services to Audit Clients. The Accounting Review 68 (1):135-150.

DeAngelo, L. E. 1981a. Auditor independence, 'low balling', and disclosure regulation. Journal of Accounting and Economics 3 (2):113-127.

. 1981b. Auditor size and audit quality. Journal of Accounting and Economics 3 (3):183-199.

DeAngelo, L. E. 1986. Accounting numbers as market valuation substitutes: A study of management buyouts of public stockholders. The Accounting Review 61 (3):400-420.

Dechow, P., W. Ge, and C. Schrand. 2010. Understanding earnings quality: A review of the proxies, their determinants and their consequences. Journal of Accounting and Economics 50 (2-3):344-401.

Dechow, P. M., and I. D. Dichev. 2002. The quality of accruals and earnings: The role of accrual estimation errors. The Accounting Review 77 (s-1):35-59.

Dechow, P. M., M. R. Huson, and R. G. Sloan. 1994. The Effect of Restructuring Charges on Executives' Cash Compensation. The Accounting Review 69 (1):138-156.

Dechow, P. M., A. P. Hutton, J. H. Kim, and R. G. Sloan. 2012. Detecting earnings management: A new approach. Journal of Accounting Research 50 (2):275334.

Dechow, P. M., S. A. Richardson, and I. Tuna. 2003. Why are earnings kinky? An examination of the earnings management explanation. Review of Accounting Studies 8 (2):355-384.

Dechow, P. M., and C. M. Schrand. 2004. Earnings Quality. http://www.cfapubs.org/doi/pdf/10.2470/rf.v2004.n3.3927: Foundation of CFA Institute.

Dechow, P. M., and R. G. Sloan. 1991. Executive incentives and the horizon problem: An empirical investigation. Journal of Accounting and Economics $14(1): 51-89$.

Dechow, P. M., R. G. Sloan, and A. P. Sweeney. 1995. Detecting Earnings Management. The Accounting Review 70 (2):193-225.

1996. Causes and Consequences of Earnings Manipulation: An Analysis of Firms Subject to Enforcement Actions by the SEC. Contemporary Accounting Research 13 (1):1-36. 
DeFond, M. L. 1992. The association between changes in client firm agency costs and auditor switching. Auditing-a Journal of Practice \& Theory 11 (1):1631 .

DeFond, M. L., and C. W. Park. 1997. Smoothing income in anticipation of future earnings. Journal of Accounting and Economics 23 (2):115-139.

DeFond, M. L., K. Raghunandan, and K. R. Subramanyam. 2002. Do Non-Audit Service Fees Impair Auditor Independence? Evidence from Going Concern Audit Opinions. Journal of Accounting Research 40 (4):1247-1274.

DeFond, M. L., and K. R. Subramanyam. 1998. The Effect of Audit Quality on Earnings Management. Contemporary Accounting Research 15 (1):1-24.

Dimson, E. 1979. Risk measurement when shares are subject to infrequent trading. Journal of Financial Economics, 7(2), 197-226.

DuCharme, L. L., P. H. Malatesta, and S. E. Sefcik. 2004. Earnings management, stock issues, and shareholder lawsuits. Journal of Financial Economics 71 (1):27-49.

DuCharme, L. L., P. H. Malatesta, S. E. Sefcik, and L. Soffer. 2001. Earnings management: IPO valuation and subsequent performance. Journal of Accounting Auditing and Finance 16 (4):369-400.

Dunstan, K., G. Gallery, and T. P. Truong. 2011. Public regulatory reform and management earnings forecasts in a low private litigation environment. Accounting \& Finance 51 (2):437-465.

Durtschi, C., and P. Easton. 2005. Earnings Management? The Shapes of the Frequency Distributions of Earnings Metrics Are Not Evidence Ipso Facto. Journal of Accounting Research 43 (4):557-592.

Elgers, P. T., R. J. Pfeiffer Jr, and S. L. Porter. 2003. Anticipatory income smoothing: a re-examination. Journal of Accounting and Economics 35 (3):405-422.

Fatima, A. 2011. Audit fees and discretionary accruals: compensation structure effect. Managerial Auditing Journal 26 (2):90-113.

Feynman, R. P. 1992. Surely You're Joking, Mr.Feynman!: Adventures of a Curious Character Vintage, UK: W. W. Norton \& Company, Inc

Francis, J. R. 2004. What do we know about audit quality? The British Accounting Review 36 (4):345-368.

Francis, J. R., and J. Krishnan. 1999. Accounting Accruals and Auditor Reporting Conservatism. Contemporary Accounting Research 16 (1):135-165. 
Francis, J. R., and D. T. Simon. 1987. A Test of Audit Pricing in the Small-Client Segment of the U. S. Audit Market. The Accounting Review 62 (1):145-157.

Francis, J. R., and D. Wang. 2008. The Joint Effect of Investor Protection and Big 4 Audits on Earnings Quality around the World. Contemporary Accounting Research 25 (1):157-191.

Francis, J. R., and E. R. Wilson. 1988. Auditor Changes: A Joint Test of Theories Relating to Agency Costs and Auditor Differentiation. The Accounting Review 63 (4):663-682.

Francis, J. R., and M. D. Yu. 2009. Big 4 Office Size and Audit Quality. The Accounting Review 84 (5):1521-1552.

Frankel, R. M., M. F. Johnson, and K. K. Nelson. 2002. The Relation between Auditors' Fees for Nonaudit Services and Earnings Management. The Accounting Review 77:71-105.

Fudenberg, D., and J. Tirole. 1995. A theory of income and dividend smoothing based on incumbency rents. Journal of Political Economy 103 (1):75-93.

Giroux, G. 2004. Detecting Earnings Management. Hoboken, New Jersey: Wiley.

Gist, W. E. 1994. A research note on the relationship between regulation and audit firm size on audit fees. Journal of Accounting, Auditing \& Finance 9 (2):381-396.

Graham, J. R., C. R. Harvey, and S. Rajgopal. 2005. The economic implications of corporate financial reporting. Journal of Accounting and Economics 40 (13):3-73.

Griffin, P. A., D. H. Lont, and Y. Sun. 2009. Governance regulatory changes, International Financial Reporting Standards adoption, and New Zealand audit and non-audit fees: empirical evidence. Accounting \& Finance 49 (4):697-724.

Gujarati, D. N. P., Dawn C. 2009. Basic econometrics. 5th ed. Boston: MeGrawHill.

Gul, F. A., C. J. P. Chen, and J. S. L. Tsui. 2003. Discretionary Accounting Accruals, Managers' Incentives, and Audit Fees. Contemporary Accounting Research 20 (3):441-464.

Hackenbrack, K., N. Jenkins, and M. Pevzner. 2011. Relevant but Delayed Information in Negotiated Audit Fees: Evidence from Stock Price Crashes. Available at SSRN 1668983. 
Hafzalla, N., R. Lundholm, and E. M. Winkle. 2011. Percent accruals. The Accounting Review 86 (1): 209 - 236.

Hagerman, R. L., and M. E. Zmijewski. 1979. Some economic determinants of accounting policy choice. Journal of Accounting and Economics 1 (2):141161.

Hay, D., and D. Jeter. 2011. The pricing of industry specialisation by auditors in New Zealand. Accounting and Business research 41 (2):171-195.

Hay, D., R. Knechel, and V. Li. 2006a. Non-audit Services and Auditor Independence: New Zealand Evidence. Journal of Business Finance \& Accounting 33 (5-6):715-734.

Hay, D. C., W. R. Knechel, and N. Wong. 2006b. Audit fees: A meta-analysis of the effect of supply and demand attributes. Contemporary Accounting Research 23 (1):141-191.

Hayn, C. 1995. The information content of losses. Journal of Accounting and Economics 20 (2):125-153.

Healy, P. M. 1985. The effect of bonus schemes on accounting decisions. Journal of Accounting and Economics 7 (1-3):85-107.

Healy, P. M., and J. M. Wahlen. 1999. A review of the earnings management literature and its implications for standard setting. Accounting Horizons 13 (4):365-383.

Heninger, W. G. 2001. The Association between Auditor Litigation and Abnormal Accruals. The Accounting Review 76 (1):111-126.

Holthausen, R. W., D. F. Larcker, and R. G. Sloan. 1995. Annual bonus schemes and the manipulation of earnings. Journal of Accounting and Economics 19 (1):29-74.

IFAC. 2009. International Stardard on Auditing 210 - Agreeing the terms of audit engagements, edited by IFAC. http://www.ifac.org.

Jackson, S. B., and X. Liu. 2010. The Allowance for Uncollectible Accounts, Conservatism, and Earnings Management. Journal of Accounting Research 48 (3):565-601.

Jenkins, J. G., and K. Krawczyk. 2001. The Influence Of Nonaudit Services On Perceptions Of Auditor Independence. Journal of applied business research 17 (3):73-79. 
Johl, S., C. A. Jubb, and K. A. Houghton. 2007. Earnings management and the audit opinion: evidence from Malaysia. Managerial Auditing Journal 22 (7):688-715.

Johnson-Moreno, H. 2003. To Your Health. Journal of Accountancy 196 (3):65-69.

Jones III, A., C. S. Norman, and B. Wier. 2010. Healthy lifestyle as a coping mechanism for role stress in public accounting. Behavioral Research in Accounting 22 (1):21-41.

Jones, J. J. 1991. Earnings Management During Import Relief Investigations. Journal of Accounting Research 29 (2):193-228.

Kaplan, R. S. 1985. Evidence on the effect of bonus schemes on accounting procedure and accrual decisions. Journal of Accounting and Economics 7 (1):109-113.

Karen, V. P., P. Michael, and C. Cordery. 2011. Auditing: Theory and Practice in New Zealand. Sixth ed: Pearson Education New Zealand.

Kasznik, R., and M. F. McNichols. 2002. Does meeting earnings expectations matter? Evidence from analyst forecast revisions and share prices. Journal of Accounting Research 40 (3):727-759.

Kinney, W. R., Z.-V. Palmrose, and S. Scholz. 2004. Auditor Independence, NonAudit Services, and Restatements: Was the U.S. Government Right? Journal of Accounting Research 42 (3):561-588.

Knechel, W. R., and D. S. Sharma. 2012. Auditor-Provided Nonaudit Services and Audit Effectiveness and Efficiency: Evidence from Pre- and Post-SOX Audit Report Lags. Auditing: A Journal of Practice \& Theory 31 (4):85-114.

Knechel, W. R., D. S. Sharma, and V. D. Sharma. 2012. Non-Audit Services and Knowledge Spillovers: Evidence from New Zealand. Journal of Business Finance \& Accounting 39 (1-2):60-81.

Kothari, S., A. J. Leone, and C. E. Wasley. 2005. Performance matched discretionary accrual measures. Journal of Accounting and Economics 39 (1):163-197.

Krishnan, G. V. 2003. Audit Quality and the Pricing of Discretionary Accruals Auditing: A Journal of Practice \& Theory 22 (17):109-126.

Larcker, D. F., and S. A. Richardson. 2004. Fees paid to audit firms, accrual choices, and corporate governance. Journal of Accounting Research 42 (3):625-658. 
Lee, H. Y., T. O'Keefe, and M. Stein. 2003. Client characteristics, abnormal accruals and auditor switches: An empirical study. Asia-Pacific Journal of Accounting \& Economics 10 (1):31-56.

Levitt, A. 2011. Renewing the Covenant With Investors 2000 [cited 2011]. Available from http://www.sec.gov/news/speech/spch370.htm.

López, D. M., and G. F. Peters. 2012. The effect of workload compression on audit quality. Auditing: A Journal of Practice \& Theory 31 (4):139-165.

Lopez, T. J., and L. Rees. 2002. The effect of beating and missing analysts' forecasts on the information content of unexpected earnings. Journal of Accounting, Auditing \& Finance 17 (2):155-184.

Mauldin, E. G. 2003. Improving Auditor Independence - The Principles vs. Standard Debate: Some Evidence about the Effects of Type and Provider of Non-Audit Services on Professional Investors' Judments. Research in Accounting Regulation 16 (0):159-169.

McNichols, M., and G. P. Wilson. 1988. Evidence of earnings management from the provision for bad debts. Journal of Accounting Research 26:1-31.

McNichols, M. F. 2002. The Quality of Accruals and Earnings: The Role of Accrual Estimation Errors: Discussion. The Accounting Review 77:61-69.

Melancon, B. 2000. Frontline Views. Journal of Accountancy 190 (4):26-28.

Menon, K., and D. D. Williams. 2001. Long-Term Trends in Audit Fees. Auditing: A Journal of Practice \& Theory 20 (1):115-136.

Nwaeze, E. T. 2001. The adjustment process of accruals: empirical evidence and implication for accrual research. Review of Quantitative Finance and Accounting 17 (2):187-211.

NZICA. 2009. International Standard on Auditing (New Zealand) 210 - Agreeing the terms of Audit Engagements, edited by NZICA. www.nzica.com.

NZSEC. 2007. Independent Audit Regulation and Oversight in New Zealand. http://www.infonews.co.nz/news.cfm?id=5089: Securities Commission New Zealand.

O'Brien, R. M. 2007. A caution regarding rules of thumb for variance inflation factors. Quality \& Quantity 41 (5):673-690.

Palmrose, Z.-V., and S. Scholz. 2004. The Circumstances and Legal Consequences of Non - GAAP Reporting: Evidence from Restatements. Contemporary Accounting Research 21 (1):139-180. 
Perry, S. E., and T. H. Williams. 1994. Earnings management preceding management buyout offers. Journal of Accounting and Economics 18 (2):157-179.

Raghunandan, K. 2003. Nonaudit services and shareholder ratification of auditors. Auditing: A Journal of Practice \& Theory 22 (1):155-163.

Rangan, S. 1998. Earnings management and the performance of seasoned equity offerings. Journal of Financial Economics 50 (1):101-122.

Reynolds, J. K., and J. R. Francis. 2000. Does size matter? The influence of large clients on office-level auditor reporting decisions. Journal of Accounting and Economics 30 (3):375-400.

Ronen, J., and V. Yaari. 2007. Earnings management: emerging insights in theory, practice, and research. New York: Springer.

Roosenboom, P., T. Van Der Goot, and G. Mertens. 2003. Earnings management and initial public offerings: Evidence from the Netherlands. The International Journal of Accounting 38 (3):243-266.

Roychowdhury, S. 2006. Earnings management through real activities manipulation. Journal of Accounting and Economics 42 (3):335-370.

Rusmin, R. 2010. Auditor quality and earnings management: Singaporean evidence. Managerial Auditing Journal 25 (7):618-638.

Sawicki, J., and K. Shrestha. 2008. Insider Trading and Earnings Management. Journal of Business Finance \& Accounting 35 (3-4):331-346.

Schelleman, C., and W. R. Knechel. 2010. Short-term accruals and the pricing and production of audit services. Auditing: A Journal of Practice \& Theory 29 (1):221-250.

Schipper, K. 1989. Commentary on earnings management. Accounting Horizons 3 (4):91-102.

Sharma, V. D., D. S. Sharma, and U. Ananthanarayanan. 2011. Client Importance and Earnings Management: The Moderating Role of Audit Committees. Auditing: A Journal of Practice \& Theory 30 (3):125-156.

Shen, C.-H., and Y.-L. Huang. 2011. Effects of earnings management on bank cost of debt. Accounting \& Finance 53 (1):265-300.

Simunic, D. A. 1980. The Pricing of Audit Services: Theory and Evidence. Journal of Accounting Research 18 (1):161-190. 
1984. Auditing, Consulting, and Auditor Independence. Journal of Accounting Research 22 (2):679-702.

Stubben, S. R. 2010. Discretionary revenues as a measure of earnings management. The Accounting Review 85 (2):695-717.

Subramanyam, K. 1996. The pricing of discretionary accruals. Journal of Accounting and Economics 22 (1):249-281.

Sweeney, J. T., and S. L. Summers. 2002. The effect of the busy season workload on public accountants' job burnout. Behavioral Research in Accounting 14 (1):223-245.

Teoh, S. H., I. Welch, and T. J. Wong. 1998. Earnings management and the underperformance of seasoned equity offerings. Journal of Financial Economics 50 (1):63-99.

Walker, A., and D. Hay. 2013. Non-audit services and knowledge spillovers: An investigation of the audit report lag. Meditari Accountancy Research 21 (1):32-51.

Wallman, S. M. H. 1996. The future of accounting, Part III: Reliability and auditor independence. Accounting Horizons 10 (4):76-97.

Watts, R. L., and J. L. Zimmerman. 1978. Towards a positive theory of the determination of accounting standards. The Accounting Review 53 (1):112134.

White, H. 1980. A heteroskedasticity-consistent covariance matrix estimator and a direct test for heteroskedasticity. Econometrica: Journal of the Econometric Society 48 (4):817-838.

World Bank. 2011a. Gross domestic product 2011. http://databank.worldbank.org/databank/download/GDP.pdf.

- 2011b. World Development Indicators. http://databank.worldbank.org/data/views/reports/tableview.aspx: World Bank.

$\mathrm{Wu}$, Y. W. 1997. Management buyouts and earnings management. Journal of Accounting, Auditing \& Finance 12 (4):373-389.

Wysocki, P. 2009. Assessing Earnings and Accruals Quality: US and international evidence. $\quad$ http://web.mit.edu/wysockip/www/papers/Wysocki2008.pdf: MIT Sloan School of Management 
Yoon, S. S., and G. Miller. 2002. Earnings management of seasoned equity offering firms in Korea. The International Journal of Accounting 37 (1):5778.

Zhang, B., and D. Emanuel. 2008. The provision of non-audit services and earnings conservatism: Do New Zealand auditors compromise their independence? Accounting Research Journal 21 (2):195-221. 